Muslims in Interwar Europe 


\title{
Muslim Minorities
}

\author{
Editorial Board \\ Jørgen S. Nielsen (University of Copenhagen) \\ Aminah McCloud (DePaul University, Chicago) \\ Jörn Thielmann (Erlangen University)
}

VOLUME 17

The titles published in this series are listed at brill.com/mumi 


\title{
Muslims in Interwar Europe
}

\author{
A Transcultural Historical Perspective
}

Edited by

Bekim Agai

Umar Ryad

Mehdi Sajid

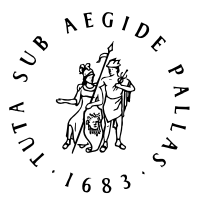

B R I L L

LEIDEN | BOSTON 

Attribution-Noncommercial 3.o Unported (CC-BY-NC 3.0) License, which permits any cial use, distribution, and reproduction in any medium, provided the original author(s) and source are credited.

Cover illustration: European Muslim Congress, 1935. Family Archive, Mohammed Ali van Beetem; Naaldwijk—The Netherlands. With gratitude to his grandson for giving access to the papers.

Library of Congress Cataloging-in-Publication Data

Muslims in interwar Europe : a transcultural historical perspective / edited by Bekim Agai, Umar Ryad, Mehdi Sajid.

pages cm. -- (Muslim minorities ; v. 17)

Includes index.

ISBN 978-90-04-28783-9 (hardback : alk. paper) -- ISBN 978-90-04-30197-9 (e-book) 1. Muslims--Europe-History. 2. Islam--Europe--History. 3. Europe--Ethnic relations. 4. Europe--History--1918-1945. I. Agai, Bekim. II. Ryad, Umar. III. Sajid, Mehdi.

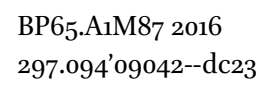

This publication has been typeset in the multilingual "Brill" typeface. With over 5,100 characters covering Latin, IPA, Greek, and Cyrillic, this typeface is especially suitable for use in the humanities. For more information, please see www.brill.com/brill-typeface.

\section{ISSN $1570-7571$}

ISBN 978-90-04-28783-9 (hardback)

ISBN 978-90-04-30197-9 (e-book)

Copyright 2016 by the Editor and Authors.

This work is published by Koninklijke Brill NV. Koninklijke Brill NV incorporates the imprints Brill, Brill Hes \& De Graaf, Brill Nijhoff, Brill Rodopi and Hotei Publishing.

Koninklijke Brill NV reserves the right to protect the publication against unauthorized use and to authorize dissemination by means of offprints, legitimate photocopies, microform editions, reprints, translations, and secondary information sources, such as abstracting and indexing services including databases. Requests for commercial re-use, use of parts of the publication, and/or translations must be addressed to Koninklijke Brill NV.

This book is printed on acid-free paper. 


\section{Contents}

Acknowledgements VII

List of Figures VIII

1 Introduction: Towards a Trans-Cultural History of Muslims in Interwar Europe 1

Bekim Agai, Umar Ryad and Mehdi Sajid

2 In Search of Religious Modernity: Conversion to Islam in Interwar Berlin 18

Gerdien Jonker

3 Salafiyya, Ahmadiyya, and European Converts to Islam in the Interwar Period 47

Umar Ryad

4 Conversion of European Intellectuals to Islam: The Case of Christiaan Snouck Hurgronje alias 'Abd al-Ghaffār 88

Pieter Sjoerd van Koningsveld

5 Muslim Bodies in the Metropole: Social Assistance and "Religious" Practice in Interwar Paris 105

Naomi Davidson

6 Indonesian Islam in Interwar Europe: Muslim Organizations in the Netherlands and Beyond 125

Klaas Stutje

7 Moros y Cristianos: Religious Aspects of the Participation of Moroccan Soldiers in the Spanish Civil War (1936-1939) $\quad 151$

Ali Al Tuma

8 Muslims of Interwar Lithuania: The Predicament of a Torn

Autochthonous Ethno-Confessional Community 178

Egdūnas Račius 
9 Transnational Life in Multicultural Space: Azerbaijani and Tatar Discourses in Interwar Europe 205

Zaur Gasimov and Wiebke Bachmann

Index 225 


\section{Acknowledgements}

We would like to deeply thank the German Federal Ministry of Education and Research (вмFB), the BMBF research project "Europa von außen gesehen" at the University of Bonn (2010-2014) and the Leiden University Centre of Islam and Society (LUCIS) for their generosity and financial support to organize the international conference "Islam in Interwar Europe and European Cultural History" at the University of Leiden (13-15 September 2012). Special thanks are due to the Federal Ministry of Education and Research (BMFB) for funding this publication and facilitating it in Open Access. We should also express our gratitude to the European Research Council for funding the project "Neither visitors, nor colonial victims: Muslims in Interwar Europe and European Trans-cultural History," currently conducted under the supervision of Umar Ryad at Utrecht University—The Netherlands (2014-2019). 


\section{List of Figures}

1.1 European Muslim Congress, $1935 \quad 2$

2.1 Hugo Hamid Marcus (1929) 37

2.2 Rolf Umar Ehrenfels (1926) 37

2.3 Faruq H. Fischer (1934) 37

3.1 Sheikh Muhammad Rashīd Riḍā (1865-1935) in his Al-Manār Office

in Cairo $\quad 5^{2}$

3.2 Id-ul-Fitr day at Woking, 10 July $1918 \quad 5^{8}$

3.3 Muslim group at the Woking Mosque 62

3.4 al-Fath 10, no. $476 \quad 80$

6.1 A Muslim Marriage in the City Hall of the Hague 1935146

6.2 Van Beetem and Indonesian Students in Cairo $1935 \quad 147$

7.1 Granada Muslim cemetery 175

8.1 Sample of the requested stamp of the Rectorate of Kaunas Mohammedan Parish, 31 October $1923 \quad 192$

8.2 Kaunas Muslim Society's stamp, on a document dated 9 September $1937 \quad 192$ 


\title{
Introduction: Towards a Trans-Cultural History of Muslims in Interwar Europe
}

\author{
Bekim Agai, Umar Ryad and Mehdi Sajid
}

The study of Muslims in interwar Europe is a rising and intriguing field of research. With the exception of two edited volumes, Islam in Interwar Europe by Nathalie Clayer and Eric Germain and Transnational Islam in Interwar Europe by Götz Nordbruch and Umar Ryad, ${ }^{1}$ the history of Muslims in Europe during this period is still fragmented into various fields of study as a side aspect of other issues. Some of these works deal with Muslims in interwar Europe as part of Middle Eastern and Asian history, colonial studies or briefly as related to European migration history. ${ }^{2}$ Other historians deliver nationally focused narratives of the Muslim presence in western, central, and eastern European territories focused on specific countries, framed within a national history. ${ }^{3}$

1 Nathalie Clayer and Eric Germain (eds.), Islam in Interwar Europe (London: Hurst \& Company, 2008); Götz Nordbruch and Umar Ryad (eds.), Transnational Islam in Interwar Europe: Muslim Activists and Thinkers (New York: Palgrave, 2014).

2 See, for example, Martin Seth Kramer, Arab Awakening and Islamic Revival: The Politics of Ideas in the Middle East (New Brunswick, NJ: Transaction Publishers, 2011), 103-111; William L. Cleveland, Islam against the West: Shakib Arslan and the Campaign for Islamic Nationalism (Austin: University of Texas Press, 2014): Juliette Bessis, "Chekib Arslan et les mouvements nationalistes au Maghreb," Revue historique 526 (1978): 467-489; Stéphane A. Dudoignon, Hisao Komatsu, and Yasushi Kosugi, Intellectuals in the Modern Islamic World: Transmission, Transformation, Communication (London: Taylor \& Francis, 2006); Manuela Williams, Mussolini's Propaganda Abroad: Subversion in the Mediterranean and the Middle East, 1935-1940 (New York: Routledge, 2006); Gilbert Achcar, The Arabs and the Holocaust: The Arab-Israeli War of Narratives (London: Saqi, 2010).

3 See, for example, Alexandre Popovic, L'Islam balkanique:Les musulmans du sud-esteuropéendans la périodepost-ottomane (Wiesbaden: Harrassowitz, 1986); Alexandre Popovic, The Turks of Bulgaria (1878-1985) (Society for Central Asian Studies, 1986); Nathalie Clayer, "La Ahmadiyya lahori et la réforme de l'islam albanais dans l'entre-deux-guerres, in Véronique Bouillier \& Catherine Servan-Schreiber," De l'Arabie à l'Himalaya. Chemins croisés en hommage à Marc Gaborieau (Paris: Maisonneuve et Larose, 2004), 211-228; Humayun Ansari (ed.), The Making of the East London Mosque, 1910-1951 (Cambridge University Press, 2011); Humayun Ansari, "Between Collaboration and Resistance: Muslim Soldiers' Identities and Loyalties in the two World Wars," Arches Quarterly 4 (2011): 18-29; Humayun Ansari, “'Burying the Dead': Making Muslim Space in Britain," Historical Research 80/210 (2007): 545-566; Humayun Ansari, "The

(C) BEKIM AGAI, UMAR RYAD AND MEHDI SAJID, 2016 | DOI 10.1163/9789004301979_002

This is an open access chapter distributed under the terms of the Creative Commons

Attribution-Noncommercial 3.o Unported (CC-BY-NC 3.0) License. 


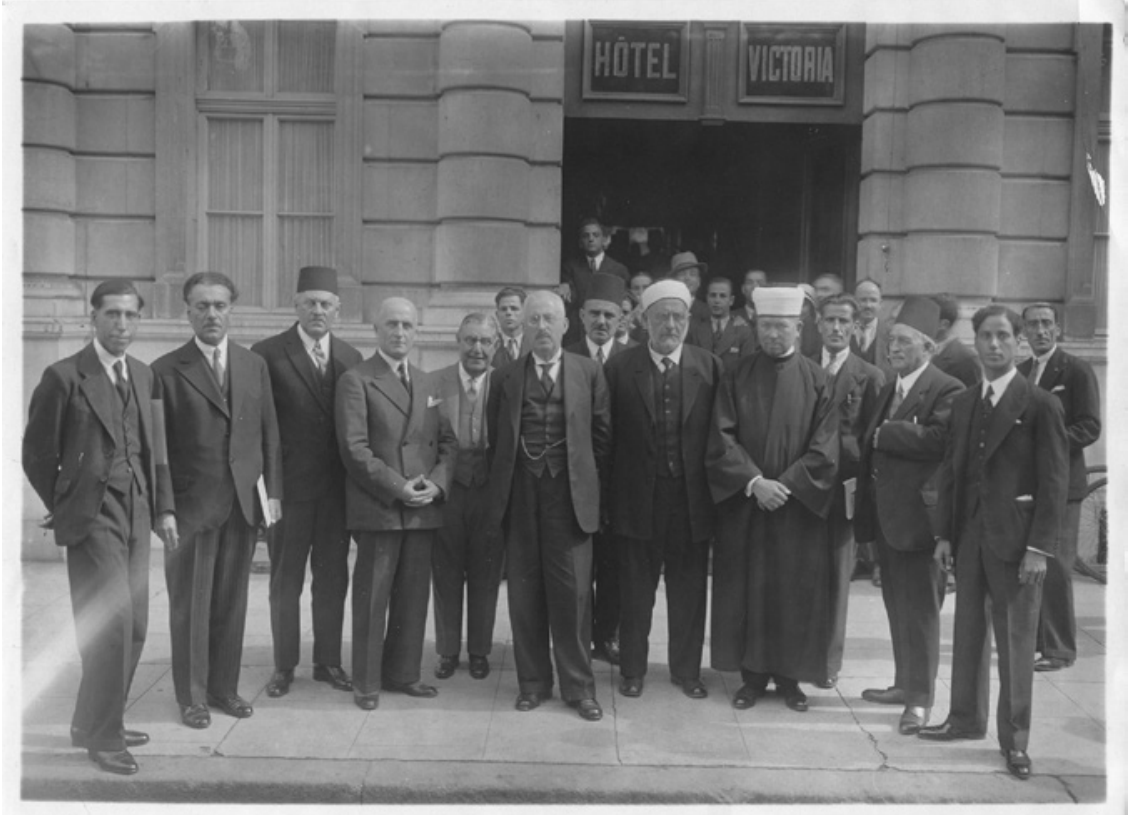

FIGURE 1.1 European Muslim Congress, 1935. Family Archive, Mohammed Alivan Beetem; Naaldwijk - The Netherlands. With gratitude to his grandson for giving access to the papers

The present volume puts the trans-cultural perspective on Muslims in interwar Europe into focus. It is the outcome of an international symposium entitled "Islam in Interwar Europe and European Cultural History," which was held at Leiden University (13-14 December 2012). It was organized by the three editors

Woking Mosque: A Case Study of Muslim Engagement with British Society since 1889," Immigrants \& Minorities 21/3 (2002), 1-24. Gerhard Höpp, Arabische und islamische Periodika in Berlin und Brandenburg 1915 bis 1945: geschichtlicher Abriss und Bibliographie (Berlin: Das Arabische Buch, 1994); Gerhard Höpp (ed.), Mufti-Papiere: Briefe, Memoranden, Reden und Aufrufe Aminal-Husainīs aus dem Exil 1940-1945 (Berlin: Schwarz, 2001); Gerhard Höpp, "Arab Inmates in German Concentration Camps until the End of World War II," in Wolfgang Schwanitz (ed.), Germany and the Middle East, 1871-1945 (Madrid u.a.: Iberoamericana, 2004); Gerhard Höpp, "Zwischen Entente und Mittelmächten: arabische Nationalisten und Panislamisten in Deutschland (1914 bis 1918)", Asien, Afrika, Lateinamerika: Zeitschrift des Zentralen Rates für Asien-, Afrika- und Lateinamerikawissenschaften in der DDR5 (1991): 827-845; Gerhard Höpp and Gerdien Jonker, In fremder Erde. Zur Geschichte und Gegenwart der islamischen Bestattung in Deutschland (Berlin: Verlag Das Arabische Buch, 1996). 
of this volume in cooperation with the Leiden University Centre for the Study of Islam and Society (LUCIS) and the research group "Europe from the Outside" at the University of Bonn sponsored by the German Federal Ministry of Education and Research (вмвғ). ${ }^{4}$ A number of scholars from various disciplines were invited to discuss how individuals and groups labeled as "Muslims" interacted with their respective European societies during the interbellum period. ${ }^{5}$ Some of the guiding questions were: What were their circumstances in their countries of residence? How did they interact as a minority group with the majority society? What impact did their connections to their counterparts in the Muslim world have on their presence and reflections in Europe? How did the attitude of their respective European societies influence their understandings of Islam and Europe? What kind of new challenges did their presence represent for the European societies? In dealing with questions of this kind the participants attempted to scrutinize some gray areas of European history and connect geographically restricted findings; this has the potential to give us a whole new perspective on the Muslim presence in interwar Europe.

The following chapters aim to fill a gap by reflecting on different examples of Muslim presences and interactions in western, central, and eastern Europe and by offering an integrative approach to include them in European history. Muslim autochthonous and émigré groups and individuals in interwar Europe are indeed difficult to categorize. The contributors try to further our understanding of Muslim social, political, intellectual, and religious activities in European history, by offering the necessary historical depth to the growing body of literature on Islam and Muslim minorities in the West. The volume thus pieces together specific case studies that emphasize the interconnections between Muslim religiosity, political activism, and modernity in interwar Europe by considering them as complex, borderless, self-organized, cross-cultural, and multi-ethnic groups. Here there is a focus on the idea of the entanglement of Muslim and European memories as "parallel histories." The volume aims to contribute to the existing debates on the historiography and territorialities of the Muslim world

4 See http://www.hum.leidenuniv.nl/godsdienstwetenschappen/nieuws/islam-in-interwar -europe-2012.html; http://media.leidenuniv.nl/legacy/r\%26b-vol3-iss4-muslims-in-interwar -europe.pdf; http://www.ioa.uni-bonn.de/abteilungen/islamwissenschaft/europe-from-the -outside/activities-and-events/international-symposium-leiden-university-netherlands -2012 (accessed 19 November 2013).

5 See the coverage of the Turkish Review (1 August 2013) to the conference: http://www .turkishreview.org/newsDetail_getNewsById.action?newsId=223353 (accessed 19 November 2013). 
by situating Muslim actors in the European context during this crucial time of global entanglements.

\section{Europe as a Transcultural Space for Muslim Action}

In recent years, historians have become interested in studying political, religious, and social movements beyond local cultural borders. In the editors' view, the focus of the present volume is innovative, as the contributions study the complexity of the Muslim presence in interwar Europe from a transcultural historical perspective. ${ }^{6}$ By studying the processes of culture transfer and border crossings of Muslim transnational actors in the interbellum period, the volume offers a more global understanding of the European past, one that goes beyond the histories of defined entities such as nations or classes. Such an approach widens our sense and scope of history by producing a more dynamic history of all those who identified themselves - or have been identified against their will—as "Muslims" within Europe and leads to a deeper reflection on their place in European and global history. Studying Muslim networks in interwar Europe from this perspective of "entanglement," and "trans-culturality" with and within Europe will, therefore, be useful in creating a global approach and a bigger picture by avoiding the numerous traps of the politics of forgetting or selective remembering beyond the historical narrative of the nation-state. The volume illustrates the historical development of Muslim border-crossing and trans-culturality by focusing on "significant contact zones, adaptation and exchange processes and moments of crossing borders in a global context" $^{\prime 7}$ in interwar Europe. An examination of the Muslim trans-cultural role in interwar Europe is useful to help us understand the transformation of Muslim identities and their imagined collective past in Europe before the nation-state.

Thus, many developments of Muslim actions in interwar Europe had global provenance, transcending national and assumed cultural boundaries. Studying these developments from a global and transcultural perspective can also be meaningful to the discussions about the histoire croisée approach, which has proved in recent years to be a challenge to the conceptual debates about how to understand "interwoven histories," and how to shed new light on histories

6 For more about this new historical approach, see Madeleine Herren, Martin Rüesch, and Christiane Sibille, Transcultural History: Theories, Methods, Sources (Berlin: Springer, 2012).

7 Herren, Rüesch, and Sibille, Transcultural History, 6. 
often already told in the much more restricted frames of national histories. ${ }^{8}$ As read against the background of this approach, the chapters in this volume should be seen as a prelude to a reconsideration of the interactions and intercrossings between European and Muslim cultural and political spheres in this crucial period. The study of Muslim actors in interwar Europe is a new "promising line of inquiry for the writing of a history of Europe," one that rethinks their position within the transcultural context. ${ }^{9}$ By focusing on Muslims and their action in this time, this history of interwar Europe can be seen as deeply interwoven with colonial subjects living in Europe, making Europe and the "Muslim" world partly overlapping spheres. The volume looks at how the Muslim presence and movements cut across national boundaries in interwar Europe, and made use of transnational ties. This consideration of Muslim "transnationalism," even by necessity and not primarily by design, is wellsuited to deepen our understanding of the transformations of Muslim identities and their imagined collective past in Europe before the formation of contemporary nation-states. The chapters that follow recount a variety of examples of Muslim engagement on the European continent in this crucial interwar time. Since such Muslim actors were active in Europe and had intensive contacts with peers across colonial lines, the focus on their activities and networks shows their significance for the history of Europe. Europe at that time was an attractive destination for Arab and Muslim students, revolutionaries, nationalist activists, political exiles, and intellectuals. Europe in this regard not only constitutes a geographical entity, but also an overarching intellectual space for Muslim actors. The latter, as is shown in the contributions, perceived interwar Europe as an "imaginary" borderless, cross-cultural, multi-ethnic and a pluri-national sphere for their political and intellectual action, a place where discussions on Islam took shape.

In that sense, Muslims in interwar Europe cannot be reduced to passive strangers of the internal European local politics and public debates. To be more specific, historians of the modern Middle East underestimate the role of interwar Muslim actors in writing a history of Islam and its relationship to modernity, whereas historians of Europe underestimate the insider's role of Muslims in intra-European developments. Some of the contributions in this volume try to present a picture of how Muslims, who belonged to various social, geographic, linguistic, intellectual, and religious backgrounds understood their shared "Islamness"; and how they impacted on the "Europeanness"

8 M. Werner and B. Zimmermann, "Beyond Comparison: histoire croisée and the Challenge of Reflexivity," History and Theory 45 (2006): 30-50.

9 Ibid., 43 . 
of those who interacted with them. In the following chapters, the contributors take into account the multiplicity of Muslim activities, religious and political institutions, and (re)interpretations of European homogeneity, civilization, and culture in the European setting. In this, the volume will definitely contribute to shaping not only a Muslim history, but a European history “à géométrie

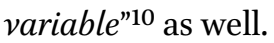

The recovery of this history of Muslims in interwar Europe, uncovered by following the trajectories of such networks, enables us to underpin the levels of interaction and fusion between local and global settings. The volume is therefore another new contribution to the different fields of European history, Islam in Europe, and Middle Eastern Studies, all coming together in the study of Islam in interwar Europe. It constitutes, on the one hand, part of the rapidly growing interest in the establishment of Islam in Europe, and on the other hand a recognition of the importance of transnational networks for the evolution of political, social, and religious movements. Thus, the use of the histoire croisée as a conceptual tool generates new concepts and shifts the scholarly focus from a study of Muslim religious/political ideals out there to see them here as part of western modernity and history. A volume like this seeks to generate "frontier knowledge" in the historical study of the Muslim pre-migration and pre-integration experience in Europe. By focusing on this field we are able to comparatively redefine the status and collective identity of Muslims in the interwar European context; their acceptance, syntheses, or rejection of influential European ideas. By studying the socio-cultural developments of Muslim activities in Europe in this formative era, we can look at the contemporary scene anew, without resorting to a neatly tailored or exaggerated hypothesis; by getting to know these first Islamic activists, we can indeed better understand the later developments of the so-called "European Islam."

\section{Muslim Activist “Frontiers" in Interwar Europe}

The interwar period was the very era in which, to a large degree, the destinies of the contemporary European and Muslim-majority societies were shaped. Contemporary Europe is indeed the result of the outcomes of this very interbellum episode, in which not only aggressive reactionary European nationalisms emerged, but also where the height of the colonial enterprise and the

\footnotetext{
10 Ibid.

11 See Ian Johnson, A Mosque in Munich:Nazis, the CIA, and the Rise of the Muslim Brotherhood in the West (Boston: Houghton Mifflin Harcourt, 2010).
} 
dichotomy between East and West was reached and culminated. In that time, Europe was not confined to its geographic borders: politics and intellectual debates in the Middle East, North Africa, and South and Southeast Asia closely followed the political modes of thinking and conflicts of the colonial centers that shaped their political and territorial realities.

Having in mind Muslim activities in the pre-World War I period, the volume traces different trajectories of Muslim activism in their new European context, in which they faced the challenges of a non-Muslim environment on them, their ideas and networks. As we shall see, being located in the metropolitan centers, Muslims in interwar Europe were in some cases able to involve themselves in both urban and overseas connections by establishing various fronts together across the European space. ${ }^{12}$ In that respect, the volume offers fascinating examples of the intersecting histories of Muslims in the international context and politics after the end of World War I. Our approach is to situate their history among other actors in Europe and reconstruct the consequences of their interaction with non-Muslims and non-Muslim institutions in terms of Muslims' experiences and self-understanding. By concentrating on Muslims living in and interacting with European societies, the central thrust of the book seeks to analyze the extent of the likely coincidence and potential interrelations of Muslim self-images and local conditions.

In their attempt to overturn France and Britain's domination of the postWorld War I international order, a number of Muslims allied themselves to anti-imperialist, leftist, Fascist, and Nazi coalitions in their anti-imperial struggles. ${ }^{13}$ However, their "counterparts" in central and eastern Europe seem to

12 See David Motadel, "The Making of Muslim Communities in Western Europe, 1914-1939," in Nordbruch and Ryad, Transnational Islam, 13-44.

13 See Peter Wien, "Coming to Terms with the Past," International Journal of Middle East Studies 42 (2010): 311-321; Peter Wien, "The Culpability of Exile: Arabs in Nazi Germany," Geschichte und Gesellschaft 37 (2011): 332-358; Götz Nordbruch, "Cultural Fusion' of Thought and Ambitions? Memory, Politics and the History of Arab-Nazi German Encounters," Middle Eastern Studies 47, no. 1 (2011): 183-194; Israel Gershoni, "Egyptian Liberalism in an Age of 'Crisis of Orientation': Al Risala's Reaction to Fascism and Nazism, 1933-39," International Journal of Middle East Studies 31 (1999): 551-576; Israel Gershoni, "Der verfolgte Jude.' Al-Hilals Reaktionen auf den Antisemitismus in Europa und Hitlers Machtergreifung," in Blind für die Geschichte? Arabische Begegnungen mit dem Nationalsozialismus, ed. Gerhard Höpp et al. (Berlin: Klaus Schwarz Verlag, 2004), 39-72; Israel Gershoni and James P. Jankowski, Confronting Fascism in Egypt: Dictatorship versus Democracy in the 1930s (Stanford, CA: Stanford University Press, 2009); Ethan Katz, 'Did the Paris Mosque Save Jews?: A Mystery and its Memory,' Jewish Quarterly Review 102, no. 2 (2012), 256-287; Raffael Scheck, 'Nazi Propaganda toward French Muslim Prisoners 
have had not only different self-representations, but also different religious and political motivations. ${ }^{14}$ As outside observers from within, Muslims in interwar Europe pushed the discussions beyond the question of anti-colonial nationalism to include the Muslim imaginations of the races, civilization, and religion in the West. While they based their claims to authenticity on Islam and its nostalgic past, they indirectly created multifaceted representations, perceptions, and narratives about Europe. By utilizing the writings and images of Europe made by Muslim exiles, we can trace the alternative views and diagnosis of the international structure of ideas and powers that Muslims offered in their attempts to find their place in the international domain.

In their new setting, Muslims in interwar Europe attempted to assert themselves as components of the emerging colonial nation-states they now belonged to on the one hand, but they had to recognize the reality and agony of colonialism in the Muslim world as such on the other. Interestingly, their presence in interwar Europe intensified their daily and constant encounters with Europe as the colonizer, which they now experienced from within. Nationalism as interpreted by Muslims adapted itself to its interwar variety of guises, causes, and transitions. These Muslim political actions took place across the boundaries of Europe and their places of origin as responses to various international political upheavals.

We should also emphasize that the relation of Muslim actors to Europe has been a longstanding crucial point of reference in contemporary debates

of War,' Holocaust and Genocide Studies 26, no. 3 (2012), 447-477. Among other works that selectively look for affinity between Islam and Nazism or Fascism, J. Herf, The Jewish Enemy: Nazi Propaganda during World War II and the Holocaust (Cambridge, MA: Harvard University Press, 2006); J. Herf, Nazi Propaganda for the Arab World (New Haven, Ст: Yale University Press, 2009); J. Herf, "Nazi Germany's Propaganda Aimed at Arabs and Muslims During World War II and the Holocaust: Old Themes, New Archival Findings," Central European History 42 (2009): 709-736; Matthias Kuentzel, Jihad and Jew-hatred: Islamism, Nazism and the Roots of 9/11 (New York: Telos Press Publishing, 2007); David G. Dalin et al., Icon of Evil: Hitler's Mufti and the Rise of Radical Islam (Transaction Publishers, 2009); K.M. Mallmann and M. Cüppers, Halbmond und Hakenkreuz: Das Dritte Reich, die Araber und Pal a stina (Darmstadt: WissenschaftlicheBuchgesellschaft, 2006).

14 See, for example, Katarzyna Górak-Sosnowska (ed.), Muslims in Poland and Eastern Europe: Widening the European Discourse on Islam (Warsaw: University of Warsaw, Faculty of Oriental Studies, 2011); Jozo Tomasevich, War and Revolution in Yugoslavia, 1941-1945: Occupation and Collaboration (Stanford, cA: Stanford University Press, 2001), 466-510; Marko Attila Hoare, The Bosnian Muslims in the Second World War: A History (London: Hurst, 2013); Emily Greble, Sarajevo, 1941-1945: Muslims, Christians, and Jews in Hitler's Europe (Ithaca, NY: Cornell University Press, 2011); David Motadel, Islam and Nazi Germany's War (Cambridge, MA: Harvard University Press, 2014). 
among Muslim intellectuals and activists. The European experience and reference is crucial for a proper "Islamic argument" in the political and intellectual debate and until today bears the legacy of this encounter. In the colonial era Muslim migrants in Europe generally developed specific insider/outsider views characterized by fascination or rejection. For Muslims in interwar Europe, local European controversies and prevailing socio-political concerns influenced their intellectual and political perceptions as well.

\section{Muslim Self-Assertion in the "Lands of the Colonizers"}

The following chapters should be read against the historical background of the legacy of Muslim reform in the late nineteenth and early twentieth century. It should be emphasized that important pan-Islamist activities took place outside the vanquished Ottoman Empire. Many Muslim actors in Europe after the end of the Great War (politicians, intellectuals, and propagandists) considered pan-Islam as the only practical way to continue their political activity. ${ }^{15} \mathrm{~A}$ number of Muslim activists in interwar Europe therefore inherited the legacy of modernist Islamic reform and pan-Islam that strove for Muslim unity across different groups and schools of thought. Their cosmopolitan experiences gave them access to ideas, and enabled them to communicate with people in order to foster their aspirations for religious reform and liberation from colonialism in the lands of the colonizers, i.e. Europe. Affected by a contemporary wave of

15 J.M. Landau, The Politics of Pan-Islam: Ideology and Organization (Oxford and New York: Oxford University Press, 1990), 228-230. See also C. Snouck Hurgronje, 'Heilige oorlog made in Germany,' De Gids 79 (1915), 1-33. For the English translation, see Joseph E. Gillet as The Holy War "Made in Germany (New York and London: G.P. Putnam's Sons, 1915). Gottfried Hagen, "German Heralds of Holy War: Orientalists and Applied Oriental Studies," Comparative Studies of South Asia, Africa and the Middle East 24, no. 2 (2004): 145-162. See also T. Luedke, Jihad Made in Germany: Ottoman and German Propaganda and Intelligence Operations in the First World War (Munster: Münster, Lit, 2005); K. Karpat, The Politicization of Islam: Reconstructing Identity, State, Faith and Community in the Late Ottoman State (Oxford and New York: Oxford University Press, 2001); D. McKale, War By Revolution: Germany and Great Britain in the Middle East in the Era of World War I (Kent and London: Kent State University Press, 1998); cf. S. McMeekin, The Berlin-Baghdad Express: The Ottoman Empire and Germany's Bid For World Power, 1898-1918 (London and New York: Belknap Press, 2010); Wolfgang G. Schwanitz, "Euro-Islam by Jihad 'Made in Germany," in Nathalie Clayer, Eric Germain (eds.), Islam in Inter-War Europe (London: Hurst \& Co. 2008), 271-301; Mustafa Aksakal, "Holy War Made in Germany’? Ottoman Origins of the 1914 Jihad," War in History 18 (April 2011): 2184-2199. 
globalization, they managed to connect themselves by cross-regional networks by which they sought to enhance their political, religious, and cultural intellectual aims. As we shall see, their political, religious, intellectual, and even military contributions were not isolated from the wider context of Europe.

In the interwar period, Muslim émigrés to Europe and indigenous European converts to Islam formed societies, congresses, and organizations in order to promote "a cosmopolitan sense of Muslim solidarity."16 The European Muslim Congress in Switzerland (1935) was the first attempt to gather Muslim activists in Europe. Its organizer, the well-known Lebanese émigré Shakīb Arslān (1869-1946) in Geneva, was a strong defender of pan-Islam, besides his panArab, anti-colonial, Islamic revivalist objectives in that time. In this congress, Arslān tried to make Geneva a center of Muslim activism, something unimaginable just one or two decades earlier; this shows the great degree to which Muslims in Europe were connected to those outside it. ${ }^{17}$ Muslim political selfassertion in interwar Europe was connected to their different ways of religious self-understanding. Because they belonged to different non-European ethnic backgrounds, their political and religious networks overlapped and even in many forms were intertwined. Besides the followers of so-called "mainstream" Islam, there were other variations of Islam, outside the mainstream, that were very active in the European public domain. The most prominent of these was the Ahmadiyya movement that operated from religious centers in London and Berlin. Their mission in Europe can in many ways be considered, in the words of Gerdien Jonker, as a Muslim "laboratory of modernity" in the European context. ${ }^{18}$ Their missionary activities in Europe were appreciated by many Muslims around the world, even if their unorthodox beliefs were highly debated. Their greatest field of success was their ability to convert indigenous Europeans to Islam; these Europeans then joined Muslim networks, published translations of Muslim texts, and explained Islam from their modern European perspective. Many of these and other converts played a significant role in the interwar period as brokers between the Muslim minorities and the majority society in Europe. Their translations of Muslim texts, their philosophical commentaries of the Islamic faith, and their self-confidence and strong sense of

16 Martin Kramer, Islam Assembled: The Advent of the Muslim Congresses (New York: Columbia University Press, 1986), 142.

17 Ibid., 142ff. For a new study on Arslān's influence on Islamic circles in Egypt from his Swiss exile, see Mehdi Sajid, Muslime in der Zwischenkriegszeit und die Dekonstruktion der Faszination vom Westen (Berlin: EB-Verlag, forthcoming).

18 Gerdien Jonker, "A Laboratory of Modernity-The Ahmadiyya Mission in Inter-war Europe," Journal of Muslims in Europe 3 (2014): 1-25. 
belonging to the European civilization made them strong allies to a variety of Muslims. Many of them left behind fascinating "conversion narratives," including statements about their choices that seemed to reflect their efforts to prove their new faith to the outside world. However, many isolated conversion stories have not been told thus far and these individual biographies must still be integrated into the larger framework of the Islamic presence in Europe. ${ }^{19}$ In general, reading their accounts of conversion reveals the complex ways in which they refashioned their spiritual orientations and melded their European lives with their Islamic identities. Their conversions to Islam included many cross-border activities that highlight significant historical aspects of connections across European and Muslim religious and cultural boundaries. In that sense, their history should not represent just the western discovery of Islam, but could also reflect the interests, perspectives, and habits of a group of people in a new religious and cultural context beyond the particular part of the world to which they belonged. Their discovery of Islam conveyed a sense of "passing" and "surpassing" that resulted from their access to western power and knowledge. 20

By consulting important primary sources, the chapters in this volume represent a significant prelude to the religious and political cultures of Islam in Europe. This can indeed shed a new light on the complexity of interactions of Muslim actors in their European contexts. By pursuing the historical antecedents and following up its culminations, this volume therefore lays a solid foundation for understanding the transitional developments and structure of various Muslim groups in the West.

19 Ali Köse, Conversion to Islam: A Study of Native British Converts (Abingdon: Routledge, 2010), 19. See John T.F. Keane, Six Months in Meccah: An Account of the Mohammedan Pilgrimage to Meccah. Recently Accomplished by an Englishman Professing Mohammedanism (London: Tinsley Brothers, 1881); Richard Burton, Personal Narrative of a Pilgrimage to el Medinah and Meccah, 2 vols. (London: G. Bell, 1913); Owen Rutter; Triumphant Pilgrimage: An English Muslim's Journey from Sarawak to Mecca, (London [etc.]: Harrap, 1937); Eric Rosenthal, From Drury Lane to Mecca: Being an Account of the Strange Life and Adventures of Hedley Churchward (also known as Mahmoud Mobarek Churchward), An English Convert to Islam (Cape Town: Howard Timmins, 1982 [repr. of 1931 edition]); H. St. John B. Philby, A Pilgrim in Arabia (London: Golden Cockerel Press, 1943); Lady Evelyn Cobbold, Pilgrimage to Mecca (London: John Murray, 1934). See also Augustus Ralli, Christians at Mecca (London: William Heinemann, 1909); A.J.B. Wavelle, A Modern Pilgrim in Mecca (London: Constable \& Company Ltd., 1913). 


\section{Contributions}

The interaction between Muslim missionaries and indigenous European converts provides a vivid example of trans-cultural entanglement. In this volume, Gerdien Jonker triggers the discussion by tracing Muslim Ahmadiyya missionary activities in interwar Berlin by focusing on German converts governed by a common quest towards new political utopias and an appetite for intellectual experiment. In the aftermath of World War I, many Germans turned their back on Christianity and went in search of spiritual alternatives. Foreign missionaries with a fresh message were welcomed, and the Weimar Republic became a stage for Hindu, Buddhist, Muslim, and alternative Christian missions. From a starting point of 1922, Jonker compares the activities of the Islamische Gemeinde Berlin and those of the Ahmadiyya Anjuman from Lahore in their German context. Jonker argues that the Muslim mission in interwar Berlin allowed for a rich transfer of knowledge, with which for one short moment the bias between East and West, periphery and center, was bridged. In order to fulfill their desire to modernize Islam, Ahmadi missionaries studied European intellectual traditions and invited Germans to attend their gatherings, which became the core of the mosque community. For their part, the Germans groped for ways to create the "future man" who would be able to solve the problems created by modernity. Jonker's contribution argues that visions of and experiments with man's progress in the name of modernity were at the heart of the missionary exchange, and he asks why converting to Islam was considered a legitimate and accepted means towards that aim. While introducing the reader to a range of convert biographies, the contribution looks for interfaces between the modernity of the missionaries and that of their recipients. The study makes clear that liberal intellectuals recognized in Islam a potential to interface with modernity, a potential that ten years later was adopted and twisted by Nazi ideologues.

Within this context of "spreading the message" in Europe, various intraMuslim disputes emerged and took sectarian shapes in their new European environments. Aspects of these sectarian conflicts were also molded by the new context and the quest of Muslims searching for a space in Europe. Some Muslims in interwar Europe, especially European converts, perceived of a universal Muslim community that should take priority above religious differences. In this respect, Umar Ryad in his contribution argues that European converts played a prominent trans-cultural role in the development of modern Islamic thought in the interwar period; they tried to bridge historically and geographically established and accepted divisions within the Muslim community, divisions which they, as newcomers, did not inherit. Whereas many of them 
maintained good relations with the Ahmadiyya missions in interwar Europe, they were also present in the debates in Salafi reformist pan-Islamic circles in Egypt. By dwelling on the materials embodied in two Muslim Salafì magazines in Egypt, al-Manār, published by Muhammad Rashīd Riḍā (1865-1935) and al-Fath, published by Rị̣ā's contemporary Syrian writer and activist Muhibb al-Dīn al-Khațîb (1886-1969), Ryad emphasizes that although Salafì writers held strongly negative attitudes against the Ahmadiyya, their responses were not always homogenous. On the one hand, Muslim reformists harshly attacked Ahmadiyya doctrines, but on the other hand, in many cases they also praised their missionary work in Europe. After a short term appraisal of the Ahmadiyya success in Europe, many disputes began to emerge and finally deteriorated their relations; reaching a peak in the mid-193os. Many converts left the Ahmadiyya missions and started to establish their own organizations and societies in protest of the Ahmadiyya's refusal to recant Ghulam Ahmad's beliefs altogether. This chapter shows that although there were multiple and deeplyrooted conflicts between the Salafiyya and Ahmadiyya based on principles that could not be compromised, the presence of European converts as new engaging figures unconsciously created a certain commonality between these disagreeing Muslim branches, whose role in Europe became entwined. They all had one goal in common, namely the relevance of Islam on European soil.

Converts played a crucial role in the Islamic community in interwar Europe; and conversion took different forms. Reflecting on the role of European converts to Islam in intercultural communication and Islamic scholarship, Pieter Sjoerd van Koningsveld distinguishes between three main types of conversion: (1) permanent conversion, where the convert acts out of free will and personal conviction and therefore believes it to be a permanent step, (2) forced or fraudulent conversion, and (3) conversion of convenience, which is an insincere form of conversion performed to obtain certain interests, like marriage, access for one's children to a confessional school, access to a club or place open to adherents of a particular religion. Van Koningsveld sheds light on the controversial conversion of the Dutch orientalist Christiaan Snouck Hurgronje $\left(1857^{-1936)}\right.$ as a "semi-permanent" conversion. He argues that Snouck Hurgronje's conversion started as a temporary one, but developed into a more permanent form. After converting for a pragmatic reason, to join the pilgrimage and observe Muslim networks there, the knowledge that he remained a Muslim was restricted to a segment of Snouck Hurgronje's Muslim network, which he maintained after his journey to Mecca in the years 1884 and 1885 . Towards his European network, Snouck was crystal-clear in "defending" his conversion as merely a means to obtain access to Mecca and be accepted in a Muslim society. Van Koningsveld considers Snouck Hurgronje's conversion of 
convenience as perhaps the most successful case in colonial history of the instrumentalization of Islam for the benefit of the Islamic policies of the rulers and for the development of ethnological field studies. The key people in his Muslim network not only consolidated his social position within Muslim circles, but also enabled him to acquire his authority among Muslims, such that he acquired prestige as a Muslim religious scholar himself. He was even sometimes addressed by his Muslim interlocutors as the "Mufti of Batavia," and even as "Shaykh al-Islām fỉ al-Diyār al-Jāwiyya." Being addressed as an authority for Islam in the Netherlands and in Jawa clearly shows the supranational space in which the "Muslim world" and "Europe" could no longer be thought of as clearly distinguished units.

In his contribution, Klaas Stutje studies Indonesian students in the Netherlands during the interwar period; particularly Snouck Hurgronje's contemporaries. Although there were relatively few Muslim residents living in the Netherlands before World War II, those present succeeded in building organizations and infrastructures of their own, and are examples of early forms of Muslim self-organization in Europe. Stutje writes a Dutch chapter on the transcultural history of Islam in interwar Europe. He focuses on the Muslim association of Perkoempoelan Islam, which included the mostly Indonesian migrant communities in the Netherlands, and subsequently, the 'colonial' Muslim communities of Europe as well, as it became an inner-European actor. He also describes the attitudes of Dutch authorities towards Muslim organizations in the Netherlands at that time. By illustrating its local activities and its organizers' attempts to connect with other pan-Islamic organizations, Stutje finally concludes that the Perkoempoelan Islam was not only concerned with politics in their "home countries," but had strong roots in the Dutch environment. It was more concerned with the accommodation and representation of Indonesian workers vis-à-vis the Dutch authorities than with networking abroad. Moreover, the story of the relatively small Muslim community within the Perkoempoelan Islam is illustrative of the attitude the Dutch authorities and Dutch society at large adopted towards migrant communities in general, and of the strategies these communities adopted to cope with their inherently vulnerable position. As such this aspect of the colonial past is part of general Dutch history and shows that state interactions with Muslim organizations are not new in the Netherlands.

Other European colonial states were concerned with the situation of Muslims within their borders as well. Naomi Davidson examines the interwar origins of Muslim histories in metropolitan France as a case study. She argues that the seeds for the racialization of people identified as Muslims in France were laid during this period with the state-sponsored creation of a mosque and 
other "Muslim" sites in Paris. By examining the creation and management of these new Muslim spaces by French officials and North African religious leaders, Davidson tries to write a transnational history of Islam in Europe, one that acknowledges Islam's long presence as a fact in European social and political life. By acknowledging not only the role of French colonialism, but also that of Muslim leaders, Davidson stresses how this collaborative construction of a particular vision of Islam ultimately contributed to the process of essentialization of those people identified as "Muslim." By focusing on the Paris Mosque (Mosquée de Paris) and the Franco-Muslim Hospital (Hôpital FrancoMusulman), the author argues that this particular vision of French Islam was a blend between "Muslim" and "French" civilizations. "French Islam" inscribed Islam firmly within a French republican model, yet it simultaneously maintained Islam outside the boundaries set by French secularism. The architectural and aesthetic plans for the mosque, as well as the events that marked the milestones in its development, were essential to the creation and diffusion of a version and concept of "French Islam." In that sense, it was the panoply of interwar social and political programs that depended on the establishment of the Paris Mosque that helped establish Muslims as only and eternally Muslims in metropolitan France.

While these chapters deal with Muslim history in their religious and political realms, we should not neglect the military participation of Muslims in European wars, as this also played an important role as a pretext for the establishment of the Mosquée de Paris. This definitely contributes to our understanding of European subaltern history, a "history told from below." Ali Al Tuma offers the example of the Spanish Civil War, during which Spanish society was confronted by the presence of large numbers of Muslim Moroccan soldiers on Spanish territory. Given the history of the Reconquest campaigns against the Moors in medieval times, it was rather ironic for the Spanish Nationalists to use Muslims in a so-called Cruzada against the Spanish Republic. In addition, the use of Muslim soldiers in Spain presented the problem of how to deal with the religious differences between the Moroccan soldiers and the surrounding Spanish society. Al Tuma explains that the Spanish Nationalists dealt with this by ensuring that the Moroccan soldiers stayed within the boundaries of their religious space, even when that meant enforcing an Islamic identity. This the Nationalists did to protect the religious sensitivities of the Moroccans but also because, in Spanish eyes, the Moroccans could not be considered anything but conservative religious Muslims. The Spanish Nationalist military employed religion to justify the use of Moroccan soldiers from a Christian perspective, to attract the Moroccans to their cause with Islamic rhetoric, and to separate the Moroccans from the surrounding 
Spanish culture and society on a religious basis. This chapter sheds light on an aspect of Christian-Muslim religious relations in Europe during the interwar period and the contradictory attitudes of embracing while keeping at bay the Muslim "Other."

Besides migrant groups in western Europe, Muslims in eastern and central European territories are also part of the European past. Permanent Muslim communities, mainly prisoners of war and refugees, had already settled in the Grand Dutchy of Lithuania (then a shared monarchy with Poland) in the thirteenth and fourteenth centuries. By the end of sixteenth century, these Tatar groups had lost their language, but maintained their religion. ${ }^{21}$ In his chapter, Egdūnas Račius discusses the predicament of Muslims of interwar Lithuania as a conflicted autochthonous ethno-confessional community. He attempts to uncover the process and consequences of identity change in the Tatar Muslim community in the territory of the interwar Lithuanian nation-state, as it was captured in the formal communication between the Tatar Muslim communities and state authorities. Račius shows that the once unified Muslim community of the former Grand Duchy of Lithuania, due to new geopolitical realities, mutated into several separate, even antagonistic, national Muslim communities, which, even when given a chance after several decades, resisted reunification. The birth of new national identities among Tatars of the former Grand Duchy of Lithuania is well worth a deeper analytical look as it contributes to a wider picture of identity changes and identity building among Muslims in interwar Europe. In this regard, the Lithuanian (and arguably Polish as well as Byelorussian) Tatar case differs from the otherwise stereotypically perceived process of integration and indigenization of Muslims in Europe, then and now.

Zaur Gasimov and Wiebke Bachmann look to another aspect of the discussion; they point to Azerbaijani and Tatar discourses in interwar Europe as part of the transnational lives of those who identified themselves as Muslims in a multicultural space. After the Caucasus and Crimea were occupied by the Red Army in 1920, a number of Muslim intellectuals (both Shīì and Sunnī) from Russia left for France, Poland, and Turkey. With the financial help of the Polish authorities these émigrés founded several newspapers and journals in Paris and Warsaw with the aim of continuing anti-communist activity abroad, in yet another example of non-Muslims using Muslims for their political cause and Muslims accommodating non-Muslim actors. Islam was an important theme

21 Konrad Pędziwiatr, "The Established and Newcomers' in Islam in Poland or the Intergroup Relations within the Polish Muslim Community," in Górak-Sosnowska, Muslims in Poland and Eastern Europe: Widening the European Discourse on Islam (Warsaw: University of Warsaw, 2011), 171. 
in the Azerbaijani, Tatar, and Dagestani discourses in the interwar period, as it was percieved as a cultural legacy endangered by the communist regime. Many of the contributors to the émigré journals stressed the importance of Islam even though they were adherents of secularist and nationalist ideologies. Thus a certain ambivalence with regard to Islam can be found in these discourses. The contributors argue that while those Muslims were eager to make European readers aware of the culture and the political problems in the Soviet Caucasus and the Crimea of that time, Islam played a significant role in their argumentation when they addressed their non-Muslim public, though they tempered their discussions of it, perhaps in an attempt to avoid being perceived of as "religious Muslims." 


\title{
In Search of Religious Modernity: Conversion to Islam in Interwar Berlin
}

\author{
Gerdien Jonker
}

\section{Introduction}

Throughout the interwar period, Berlin experienced the devastating effects of increasing globalization; in the aftermath of a war it had not started, it found that, nonetheless, it had to pay the costs. Towards the end of the war, which involved the loss of lives on a hitherto unknown scale, the Prussian, Ottoman, Habsburg, and Russian Empires were abolished. Russia went through a revolution that changed the political topography of Eastern Europe and inspired dreams of revolution elsewhere; Hungary was occupied and forced into Communism. Poland drew new borders, with deadly implications for the border populations, the former Habsburg Empire was cut down into minute parcels, and France, the country in which a large part of the war had been fought, emerged drastically mutilated. ${ }^{1}$

After the armistice was declared, Germany lived through a period of serious political destabilization. Most Germans failed to comprehend why they had been defeated, and it did not help that the political classes refused to acknowledge this. ${ }^{2}$ National pride was at stake. Returning divisions formed paramilitary organizations and terrorized Germany for at least four years. Between 1918 and 1922 the ultra-right created havoc in the Rhine area, the Baltic countries, and Schlesien. In Munich, a Communist regime took power. In Kiel, Hamburg, and Berlin socialist uprisings and uncontrolled street fighting created great political tension. ${ }^{3}$ From the far right to the far left, the country groped for a return to its "original" state; it invented as it went along a

1 Jane Burbank and Frederick Cooper, "War and Revolution in a World of Empires: 1914-1945," in Empires in World History, ed. Jane Burbank et al. (Princeton, NJ: Princeton University Press, 2010), 369-413.

2 John Horne and Alan Kramer, German Atrocities: A History of Denial (New Haven and London: Yale University Press, 2001), 327-400; Eric Hobsbawn, The Age of Extremes: A History of the World 1914-1991 (New York: Vintage Books, 1994).

3 Vanessa Conze, Das Europa der Deutschen: Ideen vonEuropain Deutschland zwischen Reichstradit-ion und Westorientierung (1920-1970) (Munich: Oldenbourg Wissenschaftsverlag, 2005), 25-100.

(C) GERDIEN JONKER, 2016 | DOI 10.1163/9789004301979_003 
Deutschheit (German-ness) that resulted in visions of "anti-modern modernity" 4 and vehemently opposed the democratic but feeble Weimar government.

A spiritual vacuum across Europe accompanied the political crisis. Official religion, both in its Lutheran and Catholic form, quickly lost authority. The Kaiser had been a symbol of Protestantism and when he left the country the Lutheran church was widely felt to be devoid of meaning. Likewise, the occupation of the Rhineland and the refusal of the victorious powers to unite Germany with Austria contradicted the traditional German Catholic selfunderstanding of the Christliches Abendland (Christian Occident). ${ }^{5}$ As a result, many people turned their backs on the German churches and went in search of spiritual alternatives; ${ }^{6}$ it helped that the trend toward globalization had already enhanced the level of knowledge and respect for other belief systems. In the age of modernity, the awareness of other religions not only meant the enhancement of knowledge, it also implied the freedom to choose between them. Along with the study of religious texts, theosophy in particular encouraged the study of religions through encounter, experience, and conversion. ${ }^{7}$ In the aftermath of the war, all these elements joined to create a fertile breeding ground for religious experiment. Foreign missionaries with a fresh message were welcomed, and the Weimar Republic became a stage for Hindu, Buddhist, Muslim, and alternative Christian missions.

After 1923, when a fragile equilibrium began to take hold, Berlin quickly became the cultural capital of continental Europe. A magnet for artists, writers, cinematographs, and actors, it became the avant-garde center of European modernity. Journalists representing the main European and American dailies joined ranks in order to report about revolutionary progress and its backlashes. ${ }^{8}$ As many as 500,000 refugees from Russia flooded Berlin on their way to the Americas, among them the Russian-Jewish intelligentsia and revolutionary art-

4 Anselm Doering-Manteuffel, "Suchbewegungeninder Moderne. Religion im politischen Feldder Weimarer Republik," in Religion und Gesellschaft. Europa im 20. Jahrhundert, ed. Friedrich Graf and Klaus Große Kracht (Köln/Weimar/Wien: Böhlau, 2007), 177.

5 Doering-Manteuffel, “Suchbewegungen," 179.

6 Michael Klöckner and Udo Tworuschka, Religionen in Deutschland. Kirchen, GlaubensGemeinschaften, Sekten (Munich: Olzog Verlag, 1994).

7 Ulrich Linse, "Lebensreform und Reformreligionen," in Die Lebensreform. Entwürfe der Neugestaltung von Leben und Kunst umigoo, ed. Kai Buchholz et al. (Darmstadt: Haeussermedia, 2001), 193-199; Helmut Zander, Anthroposophie in Deutschland. Theosophische Weltanschauung und gesellschaftliche Praxis 1884-1945 (Göttingen: Vandenhoeck and Ruprecht,2007), 33-51.

8 Sigrid Bauschinger, "The Berlin Moderns: Else Lasker-Schülerand, 'Café Culture," in Berlin Metropolis, ed. Emily D. Bilsky (New York: Jewish Museum, 2000), 58-102. 
ists whom the revolution had betrayed. ${ }^{9}$ This amalgam of people created an extraordinary creative potential. For some time, Berlin's large apartment houses were inhabited by a floating bohemia that was critical of European civilization, sympathized with revolution, and wrote the books, produced the films, and created the art that today are among the classics of modern European art. The proponents of anti-modern modernity, the conservative elites, the National Socialists, and the right-wing paramilitary despised and hated them. ${ }^{10}$

This constellation served as the local setting in which students, writers, missionaries, and revolutionaries from Muslim countries, those who constituted the Muslim community in interwar Berlin, interacted with their host society. From yet another angle, they can be seen as part of the same globalization disaster, in which the Muslim world had perceived Germany as a friend. During the Great War the Ottoman Empire had been Germany's comrade-in-arms; Indian, Tatar, and Arab revolutionaries had been trained by German and Ottoman officers to inspire insurgencies against British colonial administrations; POw camps outside Berlin had gathered some 20,00o French, British, and Russian Muslim prisoners of war. A mosque had been erected to serve their religious needs, and a group of Tatars, reluctant to join the revolution, built the first organizational structures. For some time, the financial crash kept rents and the cost of living low, and this made university study in Berlin attractive. Thus, Berlin became the stage for a nascent Muslim community because it offered a local setting that favored the development of global, pan-Islamic ideas. ${ }^{11}$ These were voiced in a large range of Arabic, Persian, Tatar, French, and German periodicals, papers, and books that were all written, printed and published in Berlin. ${ }^{12}$

For ten years, from 1923 to January 1933, these people turned Berlin into a melting pot in which extremes prevailed: extreme bourse crashes, extreme political instability, extreme outpourings of creativity, and extreme missionary

Karl Schlögel, Das russische Berlin. Ostbahnhof Europas (Munich: Panthon, 2007); Verena Dohrn and Gertrud Pickhan, Transitund Transformation. Osteuropäisch-jüdische Migranten in Berlin 1918-1939 (Göttingen: Wallstein, 2012).

10 Werner Maser, Adolf Hitler. Mein Kampf. Geschichte. Auszüge. Kommentare (Rastatt: Moewig, 1981); Ernst von Salomon, Der Fragebogen (Hamburg: Rowohlt, 1961).

11 Gerhard Höpp, "Zwischen Moschee und Demonstration. Muslime in Berlin, 1922-1930," Moslemische Revue (1990): 135-146, (1990): 230-223, (1991): 12-19; Gerhard Höpp. 'Die Sache ist von immenser Wichtigkeit.' Arabische Studenten in Berlin (Ms, Höpp Archive), 1990; Iskander Giljazov, Muslime in Deutschland: Von den zwanziger Jahren zum 'Islamische Faktor' während des 2. Weltkrieges (MS, Höpp Archive), 1989.

12 Gerhard Höpp. Arabische und islamische Periodika in Berlin und Brandenburg 1915-1945. Geschichtlicher Abriß und Bibliographie (Berlin: Das Arabische Buch, 1994). 
activities. On 30 January 1933 when the fascist National Socialists came to power, the pluralistic society engendered by the Weimar Republic was devastated. The new regime forged political stability through the persecution of anyone who did not conform to its idea of German-ness, and it targeted communists and socialists, artists and homosexuals, political opponents, gypsies, and Jews. The remaining opponents left the country. The rest of the population conformed politically, taking membership in the Nazi party or becoming active in one of the many Nazi sub-organizations. ${ }^{13}$ The influx of migrants was stopped. Foreigners were scrutinized and refused residency permits unless they conformed to Nazi politics. Alternative religious groups were closed down or brought under government control. Muslim organizations in Berlin faced the same choices as their German neighbors: Muslim Communists fled the country, the rest, again, conformed to, or cooperated with the prevailing regime.

In this study I address Muslim missionaries together with those they targeted: Germans who during these turbulent years chose to become Muslims. Starting in 1922, when the first Muslim mission commenced, this study ends at the moment Germany entered the next war and the last missionary left the country. Within these limits, I trace Muslim missionary activities and map the different responses to them.

For two Muslim organizations especially, the establishment of a mission among the Europeans was central to their endeavor to ameliorate the situation in their home country of British India. The Islamische Gemeinde zu Berlin e.V. (IGB), invited Europeans to embrace Islam and join their revolutionary struggle. For the Ahmadiyya Anjumani-Isha'ati-Islam (AAII), missionary work among the Europeans implied the creation of a trans-cultural religious space in which Indians and Germans met as equals and sought individual progress. ${ }^{14}$ Those were very different aims. In their quest for freedom, the IG B did not exclude the use of weapons, whereas the Ahmadiyya followed Gandhi and developed methods of non-violence. For the AAII, mission among the Europeans was the primary aim and its missionaries went about it in ways that

13 In 1933, when the NSDAP came to power, this party already counted 2.5 million members. To avoid the influx of nominal members, the regime put a stop on new memberships until 1937. Once this was removed, membership mounted to 11.5 million of a total population of 66 million inhabitants. Available online: http://www.bundesarchiv.de/oeffentlichkeitsarbeit/ bilder_dokumente/oo757/index-11.html.de.

14 The competing Ahmadiyya Qadiani branch tried to do the same but failed for a variety of reasons. See Gerdien Jonker "A Laboratory of Modernity—The Ahmadiyya Mission in Interwar Europe," Journal of Muslims in Europe 3 (2014): 1-25; Missionizing Europe: The Ahmadiyya Quest for Religious Progress 1900-1965 (Leiden: Brill, 2015). 
were highly professional, whereas the IG B first of all ministered to Muslim émigrés because what it needed was political solidarity, not converts in search of personal redemption. As a result, the two organizations were in constant competition. ${ }^{15}$

While introducing the reader to a range of convert biographies, in this contribution I look for interfaces between different ideas of, and searches for, modernity. During the interwar period, visions of and experiments with man's progress in the name of modernity were at the heart of the transnational exchange, and for very different reasons: converting to Islam was considered a legitimate and widely accepted means towards that aim. Germans who converted to Islam covered a wide societal and political range, from revolutionaries and avant-garde artists, to conservative university professors and orientalists, to sympathizers and members of the Nazi Party, and included both Christians and Jews. Their imaginative conceptions of Islam differed accordingly and ranged from rational religion to mysticism, from a religion fit for world revolution to one with a penchant towards the military. Apart from Lev Nussimbaum and Leopold Weiss, this group has not yet been the subject of academic research. This study therefore makes a novel contribution.

Missionary activities could be traced in registry files, mission journals, the archives of the Foreign Office, as well as in the scant remains of the Ahmadiyya Mosque Archive. Tracing the convert biographies is more difficult. Some converts left only a name in the registry files, others added a photograph, still others a conversion narrative. Some wrote under a pseudonym, others changed their Christian or Jewish names for a Muslim surname. All this makes access to their lives extremely difficult. In some cases, where it was possible to establish an original name, we found traces in the national library, sometimes also in the NSDAP membership files.

In the framework of this volume on European (trans)cultural history we ask what the missionary endeavor and its German responses added to the global exchange. Did the interaction engender fresh ideas and a transfer of knowledge? Did it manage to break down cultural borders? To find answers we scrutinize the meeting between missionaries and converts while introducing the term religious modernity to describe the character of that meeting point. Our assumption is that there were various interfaces between the missionaries and modernity and that experimentation with religion played a major role in the ensuing communication.

15 Jonker, “A Laboratory of Modernity”; Jonker, Missionizing Europe. 


\section{Leadership in the Missionary Field}

Let us first focus on the nascent Muslim community in Berlin. In 1922, there were already sixteen organizations in existence. ${ }^{16}$ By 1932 we count twenty political organizations with the aim of liberating Muslim home countries from colonial rule, six student organizations, and six different religious organizations that represented as many as 46 different Muslim 'nations' in their ranks. ${ }^{17}$ Situated in a non-Muslim country, leadership of this international community could only be symbolic and needed religious legitimacy in order to function. Once created, it was also subject to intense competition, in which political, dogmatic, and generational differences all played a part. In order to foster panIslamic aspirations among Muslims in Berlin, it was necessary to unite the local community under one leadership. The reality of their diversity, however, forged a different course, and created several competing Muslim leaders who incidentally also employed different missionary styles. Because these men represented the 'face' of Islam in Germany, and official interaction with German society focused on them, I introduce each briefly here.

Any attempt to create a 'Who's Who' of Muslim leadership and missionaries in interwar Berlin inevitably calls to mind Gilbert Achcar's ordering of the different political positions in the Arab world between 1933 and $1947 .{ }^{18}$ Already anticipating the Arab political scene of the 1930s, Weimar Berlin collected western-oriented liberals, Marxists, nationalists, reactionaries, and/or fundamentalist pan-Islamists. In contrast to Achcar's findings, however, in the 1930s most Muslim organizations in Berlin gravitated towards fascism, a trend that must be considered against the background of the oppressive German politics. Whereas the liberal administration of the Weimar Republic set the scene for political and cultural diversity, the Nazi regime only tolerated its own worldview, though they created a framework in which Muslim fascist responses could become articulate.

In the order of their appearance on the Berlin stage, we first meet Abdul Jabbar Kheiri (1880-1958), who, during World War I acted as an agitator against the British in the service of the Germans, and in 1922 united Berlin's Muslim population in the IG B. An Indian revolutionary working towards the liberation of the Muslim world, if need be by violent means, Kheiri combined Marxism with pan-Islamism. Global change, or so his philosophy seems to hold, had to

\footnotetext{
16 Giljazov, Muslime in Deutschland; Höpp, Zwischen Moschee und Demonstration.

17 Jonker, Missionising Europe.

18 Gilbert Achcar. Les Arabes et la Shoah (Paris: Actes sud, 2009).
} 
come about through world revolution. ${ }^{19}$ When founding the IGB, his political involvement and his mission among the Europeans seem to have closely interacted. The documents in the archive of the Foreign Office that deal with him consistently label him a Bolshevik. ${ }^{20}$ In the eyes of his community, it made him a hero: a photograph in the file, dated 1925 , reveals an authoritative man in turban and loose robes, carried in triumph on the shoulders of young men from his community.

In 1922, Kheiri also launched a mission journal, Der Islam: Ein Wegweiser zur Rettung und zum Wiederaufbau (Islam: A guide for rescue and restoring). Here, for the first time in German history, Germans were invited to embrace Islam as a way to join the world revolution. Christianity cannot play that role, the text warns, because clearly it is a concoction of fantasy and lies, full of disdain for women. Only Islam holds the key to the main concerns of the day: "world peace," "global freedom," "justice," "happiness," "development," and "progress."21 In this text, key concepts of modernity (progress, development) are closely joined to global concerns: seen from this angle, liberation of the Muslim world from colonial oppression would bring world peace, justice, and happiness. If peace and justice was what the Germans were looking for, or so the text seems to suggest, they should join the struggle and become part of the worldwide Muslim community.

The second leader who dominated these early years was Khwaja Sadr-udDin (1881-1981), a missionary trained by the Ahmadiyya of Lahore. He arrived in 1923 and built a mosque in Wilmersdorf for which he was much envied and which for a long time was the only mosque in Berlin. Thus responding to pressing needs, Sadr-ud-Din refrained from founding his own religious organization. Instead he used his energies to set up a mission post and in 1924 also launched the mission journal Moslemische Revue, in which he introduced himself as a western-oriented Muslim intellectual interested in starting a dialog with European intellectuals on the topic of peace and personal progress. His mission goal was simple and straightforward. From 1925 onwards, every issue featured 'modern' aspects of the religion and explained how to join:

To become a Muslim, a ceremony is not required. Islam is not only a rational, widely spread and practical religion, it is also in full harmony

19 AA/2 (Oct. 1928); Abdul Jabbar Kheiri, Sowjet-Rußland und die Völker der Welt (Petrograd: Verlag Kommunistische Internationale, 1924).

$20 \quad \mathrm{AA} / 1, \mathrm{AA} / 2$.

21 Der Islam. Ein Wegweiser zur Rettung und zur Wiederaufbau, ed. Jabbar Kheiri and Sattar Kheiri, 1 (1922), 17. 
with the natural human disposition. Every child is born with it. This is why becoming a Muslim does not require a transformation. One can be a Muslim without telling anyone...22

This indeed was a totally different message than that which the IG B advocated. Progress, or so the Ahmadiyya philosophy ran, was inherent in personal progress and a key concept of Islam. Except for their contribution to world pacifism (see below), the Ahmadiyya did not target global politics. Rather, they tried to create a transnational space for the meeting of different cultures. ${ }^{23}$ To Germans trying to sort out their present spiritual turmoil the Ahmadiyya mission goals indeed offered an intellectual and emotional meeting ground, one in which different approaches to European modernity, especially the concept of Lebensreform (Life reform) could be brought forward, questioned, and linked to Islam and Muslim modernization.

In 1927, a third leader entered the Berlin stage, one who, in only a few years time, superseded Kheiri, opening up the Arab community towards a more practical, western-oriented liberalism. Arriving as a student in 1923, Mohammed Nafi Tschelebi (1901-1933), founder of the Islam Institute and the Islam Archive, actively worked towards what he called "a fruitful, healthy synthesis of Islamic and European cultures." ${ }^{24}$ His concept included a critical approach to the convert influx. Tschelebi was the first to draft a set of rules for Europeans who wished to become Muslim. In all his considerations, the safeguarding of traditional religion played a leading part. As the Foreign Office observed: "Oriental attempts at modernizing....are also located in circles that want to safeguard the old religious bond, that is to say the religiously minded Arabs, Egyptians, Indians etc., even reaching into the Wahhabi camp."25 Tschelebi was not a Wahhabi. Rather, he combined a rare mix of western-oriented liberalism, religious nationalism, and pan-Islamism.

To complete the picture, we must also mention the Sufi Bewegung e.V. (Sufi movement), founded in 1925 by the missionary Hazrat Pir Inayat Khan (1882-1927). Seeking individual religious experience, this organization did not position itself politically, nor did it attract the attention of the Foreign Office or any of the media. It did, however, cater to the Ahmadiyya mosque. Eight years later, when German politics turned away from liberalism and the persecution

\footnotetext{
22 Moslemische Revue (1925): 20.

23 Jonker, "Laboratory."

24 AA/2: "An Islamic Press Agency in Berlin" (undated).

25 AA/2: "Islamische Verständigungsarbeit in Berlin" (Oct. 1928).
} 
of minorities began, it immediately dissolved itself,, ${ }^{26}$ while at about the same time the Deutsch-Moslemische Gesellschaft e.V. (the German Muslim Society, or DMG) expanded in the direction of spirituality and inclusion. As a result, some of its members, notably Hosseyn Kazemzadeh "Iranschär" (1884-1962), who had been, earlier, a revolutionary congenial to the German government and a creative publisher trying to promote the regeneration of Iran, ${ }^{27}$ re-surfaced in the Ahmadiyya mosque with an experimental mixture of theosophy and Sufi wisdom. ${ }^{28}$

Once established, the Nazi regime set the scene for a very different kind of Muslim leadership, although some years passed before the face of Islam in Berlin started to change. Between 1928 and 1936, the Ahmadiyya missionary S.M. Abdullah (1889-1956) dominated the mission activity; Kheiri left the city in 1929 and Tschelebi drowned in the summer of 1933 while swimming in a nearby lake. In 1930, while the country quickly moved towards National Socialism and intellectuals of the right and left signaled a new atmosphere of "no-nonsense," ${ }^{29}$ meaning that the chaotic market of ideas was abandoned in favor of a single solution, with the help of the Kantian philosopher Hugo Marcus (1880-1966), Abdullah founded the DMG. The initiative attracted a peculiar segment of Berlin society; in its early stages liberals, pacifists, and Nazi sympathizers mingled in a common search for a religious modernity that befitted the present age. From their contributions to the Moslemische Revue, the search seemed to have been truly open-minded, including orientalism, the meeting of "East" and "West," pacifism, gestalt psychology, life reform, rational conduct, different outlines of "future man," and an open sympathy with the newest Nazi reforms-notably hygiene and body culture (see below). Until 1933, the D MG was also widely acknowledged publicly. An inter-religious entrepreneur, Abdullah was repeatedly invited to speak before Catholic, theosophist, and Jewish audiences. ${ }^{30}$ As an active pacifist, he visited international peace conferences and drew up questionnaires to bring out the peace potential of the different world religions. ${ }^{31}$

26 VR Sufi (April 1933).

27 Jamshid Behnam, "Iranshär' and 'Iranshär, Hosayn Kazemzada,"' in Encyclopedia Iranica (2006), 13:535-536, 537-539.

28 Moslemische Revue, issue 3 (1933); issue 3-4 (1935); issue 2 (1936); cf. Jonker, Missionising Europe.

29 Salomon, Der Fragebogen, 242.

30 AMA/Interwar, 4.

31 AMA/Interwar, 5; 12-13. 
In 1933, Muhammed Ali, president of the AAII, assessed the political landslide in Germany, and came up with a positive result:

We welcome the new regime in Germany as it favors the simpler principles of life which Islam inculcates. Islam's great contribution to the civilization of the world is its solution of the wealth problem and the sex problem..... So far [as] we can see, Germany under the new regime is tackling both the wealth and the sex problem in an Islamic spirit, and there is every hope that in the future the whole of Europe would follow in its wake..... ${ }^{32}$

Thus fortified, the DMG continued to study and to single out aspects of European modernity. On the surface, nothing changed.

However, in 1935 the DMG shed the last of its liberal and pacifist members, among them the philosopher Marcus, a former Jew who had played a major role in shaping the religious search. After repeatedly receiving accusations from IG B members that the DMG "shelter[ed] communists and Jews," Abdullah wrote to the Foreign Office to introduce a new DMG board. His enumeration of the party membership reads like a directory of main Nazi organizations: "Our president Mr Boosfeld is [a] member in the Opfer-Kreis für die Nationalsozialistische Partei; our second secretary Dr Klopp von Hofe is [a] member of the NSDAP and the ss; the treasurer Mr Schubert is [a] member of the Arbeitsfront, and the first assessor, Mr Beier is member of the NSDAP."33

About the same time a man called Habibur Rahman (1901-?) appeared on the scene, incorporating the novel kind of leadership that Nazi politics allowed. Rahman was an Indian Muslim and comrade-in-arms of the future founder of independent India, Subha Chandras Bose. ${ }^{34}$ He was already studying in Berlin when Abdul Jabbar Kheiri set up the IGB,$^{35}$ but for a long time he remained invisible on the organizational level. In 1936, Rahman revived the IGB, which

32 Moslemische Revue 2-3 (1934): 45-46; AMA/Interwar, 5 .

33 AA/3 (31 August 1936). NSDAP = Opfer-Kreis für die National-Sozialistische Deutsche Partei ("Circle of Victims of the National Socialist German Party"). The NSDAP was founded in 1920; it engaged in anti-Semitism and street terror, and soon attempted a coup under the leadership of Adolf Hitler. Members who were imprisoned on account of this coup later acquired the status of victim; ss = Schutzstaffel der NSDAP ("Protective Arm of the NSDAP"); Arbeitsfront (“German Work Front”). The latter was founded in 1933, a few days after the annihilation of the trade unions.

AA/3 (20 March 1936); Jan Kuhlmann, Subhas Chandra Bose und die Indienpolitik der Achsenmächte Zeitgeschichte (Berlin: Verlag Hans Schiler, 2003), 343.

VR IGB: $7-8$. 
had been inactive after Kheiri's departure, and acted as its secretary general until, in 1938, he was elected president. ${ }^{36}$ Two years later he was also elected president of the Islam Institute, thus uniting the two organizations under one umbrella. ${ }^{37}$

Profiting from a political atmosphere that encouraged denunciation, Rahman made ample use of it to reach his goals. Between 1935 and 1939, he wrote many letters to the Foreign Office and major Arab and Indian dailies in which he denounced the Ahmadiyya for performing an "unscrupulous mission" and fostering "criminal, communist, and Jewish elements." 38 Rahman also tried to incriminate the Ahmadiyya missionary Abdullah whenever he could, claiming that the latter played tennis with his wife when "normal" Muslims were praying, that Abdullah sold pork, and had illicit contacts with German women. ${ }^{39}$ Rahman's missionary activity was limited to damaging the Ahmadiyya successes. Continuing Tschelebi's approach to converts, he also further restricted conditions on those who wanted to embrace Islam (see below).

Habibur Rahman strove for acknowledgment as the main Muslim representative vis-à-vis the Nazi regime. Although he closely cooperated the Mufti of Jerusalem Amin al-Husseini, who was favored by the Nazis, his own role in the war remained minor. ${ }^{40}$ Politically, Rahman seems to have embraced a mix of nationalist and pan-Islamist positions, and, like so many others around him, exchanged communism for fascism in response to the Nazi pressure.

\section{Converts to Different Muslim Modernities}

The mission advances of Abdul Jabbar Kheiri, head of the IGB, and those of Sadr-ud-Din, head of the Ahmadiyya mission, drew very different crowds; these differences continued to deepen as their places were taken by Habibur Rahman and S.M. Abdullah. Only three of Kheiri's converts, Albert Seiler, Khalid Banning, and Maria Hesselbach switched to the Ahmadiyya, while only

36 VR IGB: $184-199$.

37 VR IIB: 1939.

38 AA/4 (22 March 1937).

39 AA/4 (Aug.-Sept. 1936).

40 In 1936, Hafiz Abdul Rahman Peshawari, leader of the Afghan pan-Islamist movement, warned the Foreign Office against him, stating that Rahman was "a Luna park dancer and a communist" (AA/4: 20 March 1936). Spotting him as a troublemaker and denunciator, the Foreign Office kept its distance (AA/4: 1936, et passim). Rahman ended up working in the war propaganda department. 
one new Muslim from the ranks of the Ahmadiyya (Georg Konieczny) joined the IGB. The majority of the two convert circles kept their distance from each other. As we saw, the main distinction between the two mission approaches was in their position on British India, where the progress of Islam and the betterment of the political situation were interlinked. The very different solutions each put forward - world revolution versus individual progress- had different implications for the modernization of the world and the place of the German Muslims therein. To this, converts added their own distinctions. Whereas the IGB attracted the student generation born after 1900, the Ahmadiyya appealed to members of the upper middle class, many of whom were born in the last decades of the nineteenth century. In the aftermath of the war, the former age group was branded "Generation 1902" because it was too young to have experienced the front line and consequently could not claim heroic deeds; while the latter had fought in the trenches of northern France and Galicia, an experience that had utterly destabilized their lives. In this section, we encounter the two age groups at several intersections of their time line, and seek to understand how they experimented with religion in order to remedy their needs in ways that modernity allowed for.

\section{IGB-Islamia-Islam Institute}

Among the young who felt attracted to Kheiri's revolutionary message were students and artists trying to escape the German isolation that was developing; they were critical of western civilization, dared to articulate anti-war views, and to all appearances felt thrilled to join a non-European international movement. From the scant biographies that remain, one gains the impression that for them, joining Islam first of all implied joining the anti-colonial struggle in support of the liberation movements in North Africa and British India. Some fifty German and Eastern European students, flanked by a few of the older generation, first joined the IGB, then regrouped in the student organization Islamia, then finally broke away from Kheiri in 1927 by setting up the Islam Institute. Who were they?

At the height of Abdul Jabbar Kheiri's quarrel with the Islamia, ${ }^{41}$ he released a list of active IGB members, ${ }^{42}$ and acccused German Muslims especially of

41 The list features a mix of Muslim émigrés and new Muslims and numbers 163 members, a quarter of whom had European names. In the ensuing correspondence ten additional new Muslims were included. Some of the known members however, notably the women of converted couples, are never mentioned.

42 VR IGB: $159-64$. 
communism and "frequent contacts with Moscow."43 In these correspondences, the reader encounters a string of German Muslims: Dr H. 'Khalid' Banning, Ewald Brendel, Helene Bosner, Anton Dybe, Adelheid Cappelle, Albert Fischer, Dr Käthe Göritz, Friedrich 'Hassan' Heinze, Erna 'Hedije' Hoeftmann, Walther 'Hassan' Hoffmann, Bruno Kramer, Hans 'Ali' Knofke, Erwin 'Hossein' Neumann, Bruno Richter, Elsa Schiemann, Hermann Schulz, Albert 'Chalid' Seiler, Werner Voigt, Ulla Westermann, and others. ${ }^{44}$ Across the sources, we count at least two artists and painters (Bruno Richter, Elsa Schiemann), two publishers and art printers (Anton Dybe, Albert Seiler), and a string of dissertation students. Käthe Göritz, Werner Voigt, and Erwin Neumann deposited their dissertations in the Berlin National Library. Erna Hoeftmann, Albert Seiler, and Bruno Richter were affiliated with the university Institute of Oriental Studies. ${ }^{45}$ Some can be traced throughout the records of interwar Islam, notably Walther Hoffmann, Bruno Richter, and Albert Seiler, who never tired of novel attempts to re-shape the Berlin Muslim community. Of this circle, only Anton Dybeand Georg Konieczny re-emerged after the war to help restore Muslim life in Germany. ${ }^{46}$

The list features only two well known names, that of Leopold Weiss/ Muhammed Asad (1900-1982) and Lev Nussimbaum/Esad Bey (1905-1942). ${ }^{47}$ Raised in different Jewish milieus - Weiss in Lemberg, Nussimbaum in Kiev or Baku ${ }^{48}$-both arrived in Berlin with the first waves of Russian refugees. They arrived with nothing, took up oriental studies, and eventually became journalists with an oriental assignment. Both embraced Islam, but it seems that they

43 AA/2 (17 Dec. 1928).

44 After Kheiri quarreled with the Islamia, he wrote adopted Muslim names in parentheses only.

45 VR SOs: $53,57$.

46 Mohammed A. Hobohm, Neuanfänge muslimischen Gemeindelebens nachdem Krieg, 2000.

47 Günther Windhager, Leopold Weiss alias Muhammad Assad (Wien: Böhlau, 2003); Tom Reiss, Der Orientalist. Auf den Spuren von Esad Bey (Berlin: Osburg Verlag, 2008); Gerhard Höpp, Moh. Esad Bey: Nur Orient für Europäer? (unpublished Ms), 1995; Gerhard Höpp. "Noussimbaum wird Essad Bey. Annäherung an eine Biographie zwischen den Kulturen," Moslemische Revue (1996): 18-26.

48 In his first book Oil and Blood in the Orient (1928), Nussimbaum poses as the heir to an old Azerbaijani Muslim oil dynasty in Baku. But in 2009, Fuhrmann, himself an economist with Azerbaijani specialization, claimed to be in possession of Nussimbaums' birth certificate from a Kiev synagogue. For reasons of his own, he did not publish this document. Fuhrmann did publish an internal report of the German Secret Service (Gestapo), which in 1935 had arrived at the same conclusion (www.essadbey.de). 
had very different reasons. Thirty years later, Weiss describes in his autobiography his conversion experience, an intense moment in which he rejected western civilization, in which he suddenly "saw" the lack of fulfillment and the unhappiness of the wealthy Berliners sitting next to him in the U-Bahn. ${ }^{49}$ In very different fashion, Nussimbaum experimented with an exotic sounding name, weaving a fable of his oriental origin as he went along. Originally, he seems to have made a living in the Romanische Café, where he recited oriental stories in appropriate garb to the assembled bohemia. ${ }^{50}$ Later on, he outright denied his conversion, and claimed to be the offspring of a Azerbaijani Muslim oil millionaire in Baku, and a Russian bolshevist mother who happened to be imprisoned in that city at the time of marriage. ${ }^{51}$

Weiss/Asad and Nussimbaum/Esad Bey were migrants from Eastern Europe. Scrutinizing Kheiri's list, it seems that other Eastern Europeans accompanied them. The reader meets with Helene Adas, Ewald Brendel, Albert Ceasar Czernikow, Viktor Glikin, Leon Jekelzewitz, Arpad Jerenzz, Diodor Kopinski, Leowar Mirimanian, Melly Podleschewsky, Paul Warkoicz, and Eugenie Woranoff, none of whose lives could be reconstructed. Many of these family names can be traced to the passenger lists of steamers that left weekly for America. A survey through the North and South American Jewish communities suggests that many of them had Jewish roots as well.

Kheiri's ambitious plans ultimately came to nothing. Isolated after a nasty dispute over the abolishment of the khalifate, he discontinued not only the mission journal but also the yearly IG B gatherings. ${ }^{52}$ In the end, Nafi Tschelebi, the student leader of the Islam Institute, dethroned him. Tschelebi's idea of Muslim modernization was not world revolution, but the laying of foundations for future Muslim nation states. Although accused of receiving money from Moscow, ${ }^{53}$ he nonetheless acquired the trust and cooperation of important German institutions, and in only a short period of time created the Islam Institute, the Islam Archive, two periodicals, and a closely-knit local network. Tschelebi managed to give a different focus to the development of Muslim modernity in Berlin. In their estimate of the political situation, the Foreign Office judged his circle "to have completely distanced itself from the 'world

\footnotetext{
49 Muhammad Asad, The Road to Mecca (New York: Simon \& Schuster, 1993), 174-177.

$50 \quad$ Reiss, Der Orientalist, 256.

$5^{1} \quad$ Esad Bey. Öl und Blut im Orient. Meine Kindheit in Baku und meine haarsträubende Flucht durch den Kaukasus (Munich: Deutsche Verlagsanstalt, 1930), 17; Wilfried Fuhrmann. Plagiat, Lüge oder Vertrauen? Wo ist Essad-Bey? Available online: www.essadbey.de.

$5^{2}$ Jonker, Missionising Europe.

53 AA/2 (17 Oct. 1928), 3.
} 
revolutionaries' and their political-military illusions, which dominated the war and the post war period," and decided that the time had come "to begin a fruitful cooperation." 54

The Islam Institute indeed became an attractive place for many different people. The director of Das Seminar für orientalische Sprachen (Institute for Oriental Studies) at Berlin University, Prof. Kampffmeier and member of Parliament Julius Bachem sat on the board; Walther Hoffmann, Bruno Richter, and Georg Konieczny served as authors, editors, and printers of its periodicals. From the Middle East, Weiss/Asad and Nussimbaum/Esad Bey contributed articles; Erna Hedije Hoeftmann and Albert Chalid Seiler were commissioned to run a convert register and to "rethink the relationship between old and new Muslims." 55 With a view to the convert influx, this was a novel policy, and pointed towards restriction: "Inscribed in the register may be those who are able to give proof of exit from their former religious community and proof of entry to Islam. ${ }^{\prime 56}$ The phrase dips into the sensitive subject of religious belonging, revealing the fact that many new Muslims did not deem it necessary to exit from their former religious communities. Rather, as I discuss in the next section, German religious seekers preferred to move from one religious community to the next, without binding themselves.

Nonetheless, whereas many of the Muslim émigrés only stayed for the duration of their university study, German Muslims guaranteed continuity and durability for the community. There is no doubt that this circle served to anchor the Muslim community in Germany. They adopted the roles of navigator, cultural translator, and interpreter in the local framework and engaged in the transfer local knowledge. In contrast to Muslim émigrés, local Muslims knew all about the legal requirements and the political and societal expectations surrounding the founding of migrant organizations.

Khalid Banning, for instance, navigated the proceedings, which led to the foundation of the IGB. ${ }^{57}$ Hoffmann, his wife Emina, Erna Hoeftmann, and Seiler supported Nafi Tschelebi in breaking away from the IG B. ${ }^{58}$ Hoffmann even took it upon himself to file a complaint. ${ }^{59}$

\footnotetext{
54 AA/2 (17 Oct. 1928), 1.

55 Die Islamische Gegenwart. Monatszeitschrift für die Zeitgeschichte des Islam, ed. M. Nafi Tschelebi and Muhammed Hassan Hoffmann (Berlin, 1929), 1.

56 Die Islamische Gegenwart, 1.

57 VR IGB: 8 .

58 VR IGB: 20.

59 VR IGB: 58, 66-70, 79, 94-95, 104.
} 
In the mid-1930s, Hoffmann and Konieczny also supported the revival of the IG B by Habibur Rahman. Hoffmann, a former communist, sat on the board. Secretary Konieczny signed his letters with "Heil Hitler!,"60 was active in different Nazi organizations, and also acquired NSDAP membership. ${ }^{61}$ Seiler, by then head of the DMG but equally supportive of the Islam Institute, pleaded for amalgamation with the IG B, a suggestion the DMG board utterly rejected. ${ }^{62}$ For their part, Muslim émigrés increasingly considered German Muslims as insignificant. When, on 27 May 1940 Rahman finally attempted to fuse the IG B with the Islam Institute, thus creating the platform that was to be the official Muslim representative vis-à-vis the war ministries, none of them were invited any more.

\section{Ahmadiyya Lahore and the DMG}

How can one recognize a convert? The answer to this question very much depends on how the act of conversion is defined. Over the last hundred years, sociologists of religion came up with many definitions, from "a radical change of consciousness in which the individual changes both his world view and his identity," to "socially embedded happenings which are communicated through group belonging, narrations of the self and demonstrative acts." ${ }^{\prime 3}$ For some, conversion is a communicative act, for others, it signals deep psychic change. For scholars who occupy themselves with boundary marking, converts are radical transgressors of cultural borders: they quit their traditional (religious) habitat in order to adopt the space of the other. ${ }^{64}$ Seen through this lens, bodily signs that broadcast one's new solidarity seem to be a necessity: otherwise, how can the adopted community recognize that the newcomer is one of them?

Turning the pages of the Moslemische Revue, that necessity is utterly absent. Many Germans accepting Islam with the help of the Ahmadiyya missionaries published a photograph in this journal, which they labeled with their real or adopted names. In addition, some added a conversion narrative. Others wrote learned articles on aspects of Islam, in which the reader easily detects autobiographical traces. In all, fifteen individual photographs were published. Some of

\footnotetext{
6o VR IGB: 1935 .

61 Barch B: Nr.4831277.

62 VR DMG (Sept. 1938).

63 Detlev Pollack, "Was ist Konversion?" in Treten Sie ein! Treten Sie aus! Warum Menschen ihre Religion wechseln, ed. Hanno Loewy, et al. (Berlin: Parthas, 2012), 44.

64 Michele Lamont, "The Study of Boundaries Across the Social Sciences," Annual Review of Sociology 28 (2002): 167-195.
} 
those portrayed appear alone, others with Sadr-ud-Din. Two newly wed couples pose in front of the mosque. One photograph portrays a whole family.

In line with the missionaries view that "becoming a Muslim does not require a transformation" (see above), those portrayed did not stress their transgressions anywhere. They are neither adorned with 'Islamic' elements, nor do they dress up in any other special way. "Dr H. Khalid Banning," for instance, looks very much like the public prosecutor he probably was (1924). ${ }^{65}$ Banning posed with "Muhammed Taufiq Killenger," a gentleman with a military demeanor, described in an undated Ahmadiyya pamphlet from the 1930s as an adventurer who had served in different armies around the world, including the Hungarian, Austrian, Swiss, Dutch colonial, Venezuelan, and Ottoman armies. ${ }^{66}$ In 1938, he surfaces again as M.T. Killinger, enthusiastically welcoming the Nazi occupation of Sudetenland. ${ }^{67}$ During World War II, already an old man, Killinger repeatedly offered his service to the ss, which eventually employed him as director of the ss imam training. ${ }^{68}$

In the next issue, we meet with very different characters. One calls himself "Konrad Giesel," and holds a book in his hands, on which is written "With Islam, 1.X.1924." We can identify him as Konrad Algermissen, a Roman-Catholic priest who during the 1920 published a series of sociological studies on different religious "sects" with Giesel Verlag. His photograph evokes the German intellectual; in the accompanying analysis, "Thoughts on Community," Algermissen enthuses about the community potential of Islam. ${ }^{69}$ In contrast, Hanns Lobauers' photograph corroborates his self-description as a tormented Prussian officer who lost himself in the trenches. ${ }^{70}$ Only one of the ladies of this early period has wrapped herself in a kind of Indian cloth. The other two

65 There is a Dr H. Banning in the 1924 Berlin address book who lived in the Wilmersdorf borough and practiced as a public prosecutor. Since most visitors of the Wilmersdorfer mosque lived within walking distance, there is fair chance he is the same one.

$66 \mathrm{AA} / 5$.

67 "Endlich sind wir im Reich!" (Finally we are in the Reich!), Moslemische Revue (1938), 94. For 1934, we find Fischer's name on the DMG board, proof that for some time at least he was an active member.

68 Pieter Sjoerd van Koningsveld, "The Training of Imams by the Third Reich," in The Study of Religion and the Training of Muslim Clergy in Europe: Academic and Religious Freedom in the 21th Century, ed. Willem B. Drees and Pieter Sjoerd van Koningsveld (Leiden: Leiden University Press, 2008), 348-368.

69 Moslemische Revue (1925): 25-28.

$70 \quad$ Moslemische Revue (1926): 34-38. 
present the image of well-dressed upper middle-class women with short hair, and wearing pearls. ${ }^{71}$

The pattern repeats itself in the portrayals of the early 1930s. "Saffiah Irma Gohl, stud. Phil." commissioned an art photograph in which she poses as a modern German woman with a flowery band in her short hair (1931). In her conversion narrative Saffiah describes her religious quest as "a journey" past Buddha, Zoroaster, and Confucius, through the cliffs of Egyptology, Oriental Studies and Arab literature, until she finally encountered an Egyptian who became her spiritual mentor, and eventually her husband. ${ }^{72}$ In 1944, the two of them directed an inflammatory protest to the League of Nations, describing in detail the "havoc and ruin" caused by the Italian armies in Tripoli. ${ }^{73}$ Of all the German converts, she was the only one who engaged in resistance against the Nazi regime.

Also in 1931, the Moslemische Revue finally featured an oil painting of the founder of the DMG: "Dr Hamid Marcus, President of the Deutsch-Moslemische Gesellschafte.V." We behold him in the typical posture of Germany's poets and thinkers, outstretched fingers against his temple, books in the background, and a furrow between his brows.

In the scant remains of the interwar mosque archive his handwritten conversion narrative, dated 1931, survived, and corroborates his self-conception as 'thinker.' ${ }^{44}$ Studies on conversion often stress that the blueprint of any conversion narrative is a transformation from crisis to salvation, followed by the urge to give witness. ${ }^{75}$ Differently, but much in line with Ahmadiyya philosophy, Marcus stated that his journey to Islam was neither governed by crisis (like Lohbauer and other soldiers who served at the front), nor by a spiritual journey (like Gohl and others who used theosophy as a vehicle) but by continuation. As a philosophy student, he had embraced Kant, Nietzsche, and Spinoza and developed the philosophy of "mono-pluralism," and thus created the foundation of a severe kind of monotheism as he progressed. In this self-portrait he could therefore rightly stress that, while encountering Islam in the person of Sadr-ud-Din, he only re-discovered his philosophical roots.

Marcus also had Jewish roots, a fact that on the surface does not seem to have played a role in his writings. His biography still remains to be written, but

\footnotetext{
71 Moslemische Revue, photographs preceding the 1924 and 1925 issues.

72 Moslemische Revue (1931): 56-59.

73 AMA/Post-war: 2.

74 AMA/Interwar: 7 .

75 Andreas B. Kilcher, "Konversion als Erzählung," in Treten Sie in! Treten Sie aus! Warum Menschen ihre Religion wechseln, ed. Hanno Loewy et al. (Berlin: Parthas, 2012), 50-64.
} 
from his many contributions to the Moslemische Revue it is already clear that this philosopher searched for a modern religious foundation, which had outgrown the old religions, and from which could grow up as a "novel man." "Where and who are the people for whom it is worth to (re-) shape the world into a paradise? Where are these people to whom belongs the future as we want it?" he asks in "Religion and Future Man," to which he answers himself: "We will not find them, we will have to create them first."

In the last years of the Weimar Republic, Hugo Hamid Marcus truly was not the only one who raised this question. 'Novel man,' 'novel leadership', and 'people of the future' were the catchwords that governed the politics of the day, which appeared in a multitude of book titles and stood for visions of the future that ranged from modern to anti-modern, from liberal to conservative, from the far right to the far left. ${ }^{77}$

The difference between Marcus' vision, as laid down in his writings for the Moslemische Revue, and the solution that in 1933 forced its way to political power, must be sought in the open-minded curiosity with which this philosopher tried to bridge not only East and West, Christianity and Islam, but also left- and right-wing ideologies. Marcus, himself born in 1880 and a veteran of the Great War, believed in the creative powers of a young generation that had been molded by a religion that embraced rationality as well as modernity, practical humanitarianism as well as spirituality. From his writings it becomes clear that this could only be Islam.

But creating the "future man" was still very much a work in progress, its result open-ended. For the moment it led to very different profiles. Returning to the photo gallery displayed on the pages of the Moslemische Revue, two men of that young and coming generation still need to be highlighted. At the time, they seemed to incorporate the ideal Marcus envisioned.

One year after Marcus' publication, Rolf von Ehrenfels, born in 1901 in Prague, son of the gestalt therapist Christian Baron von Ehrenfels, at home in the literary and bohemian circles of Vienna, Prague, and Budapest, answered with "Islam and the Young Generation in Europe."78 Positioning himself as a man of the future, von Ehrenfels drew a parallel between Islam and certain aspects of the European Lebensreform (life reform). Among others, he addressed erotic communication, respect for the earth, the ways in which peo-

$76 \quad$ Moslemische Revue (1930): 66.

77 Friedbert Aspetsberger, 'Arnolt Bronnen.' Biografie (Wien/Köln/Wiemar: Böhlau Verlag, 1995), 412; Maser, Adolf Hitler, 315-316; Kurt Hiller, Leben gegen die Zeit. Erinnerungen (Hamburg: Rowohlt, 1969), $218 \mathrm{f}$.

78 Moslemische Revue (1931): 81-91. 


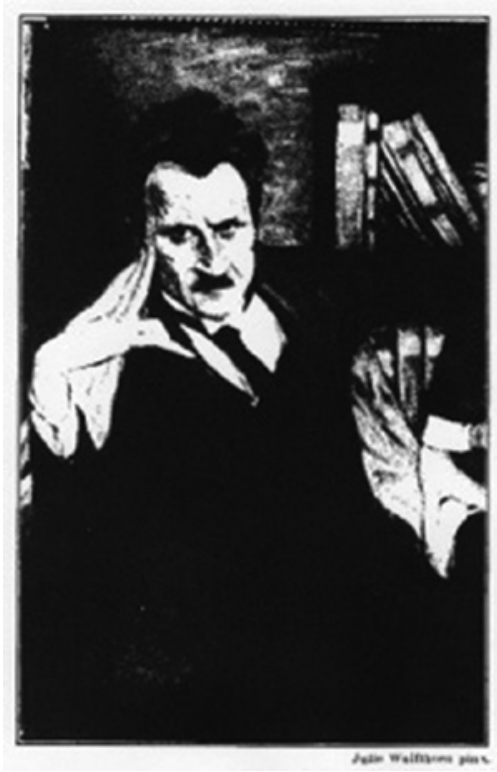

Figure 2.1 Hugo Hamid Marcus (1929). Moslemische Revue 1 (1931), p. 1 COURTESY NASIR AHMAD

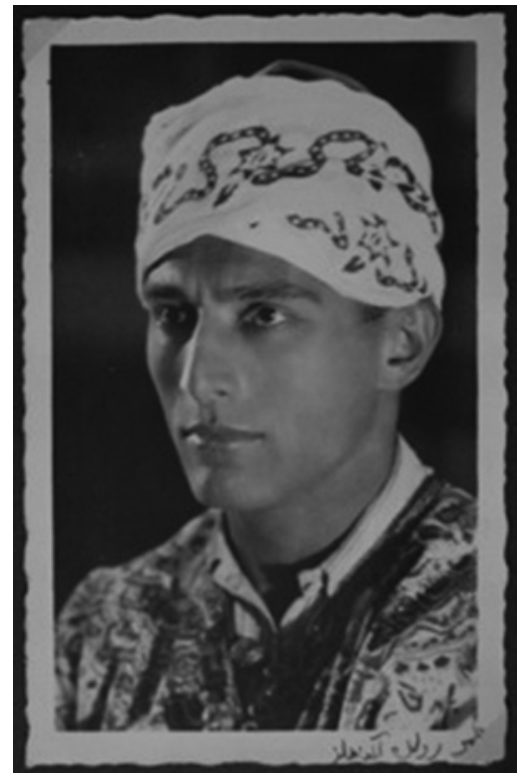

FIGURE 2.2 Rolf Umar Ehrenfels (1926). In: photo album "Mosque \& Friends", Oettinger Archive COURTESY SUHAIL AHMAD

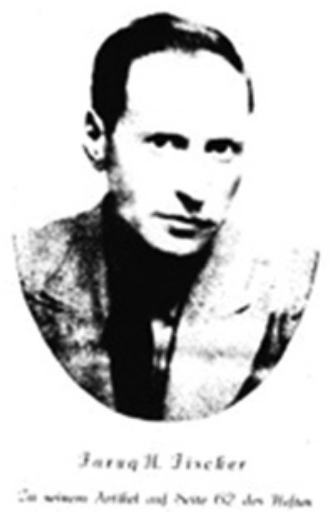

FIGURE 2.3

Faruq H. Fischer (1934). Moslemische Revue 2 (1934), p. 1 COURTESY NASIR AHMAD 
ple greet each other, dress themselves, and shape their house interiors, and thereby create a framework in which they live and communicate. Islam, he concluded, is modern because it possesses the potential to shape life in ways that are recognized as progressive in Europe. In 1931 von Ehrenfels was not yet an anthropologist, but the theory behind the article points to the future; it was already his conjecture that material frameworks shape and direct human communication and experience. In a typical fashion, von Ehrenfels' own encounter, which made him decide to embrace Islam in the first place, was an intensive experience of mosque architecture that resulted in a thick description that betrays the influence of gestalt therapy. ${ }^{79}$

Although von Ehrenfels was appointed co-editor of the Moslemische Revue and wrote several articles for the journal, he never published his photograph. We only know his contemporary face from his journey to Lahore in 1933, when he met with figures from the Ahmadiyya mother organization, and from some earlier photographs published in the Nussimbaum biography. 80

Some years later, the editors of the Moslemische Revue thought to recognize another "future man" in the popular author "Faruq H. Fischer." Invited to present a piece on the occasion of the ten-year celebration, they announced him as "the well-known author, one of the youngest Europeans who have gladly embraced Islam" 81 The accompanying photograph bears the traits of a sleek and calculating Nazi youth; his name can be traced to Hans Fischer who, in 1932 and 1933, was one of the up-and-coming young men of popular Nazi ideology. His many theater plays, advertised with titles like Jung Deutschland voran ("Young Germany to the fore"),Deutschland's Morgenrotentflammt! "Germany's dawn ignites!"), or Heb' deine Flügel, deutscher Adler...("Raise your wings, German eagle...") are full of blood and earth symbols and ugly examples of anti-Semitism, which he employed for comic effect.

What did this "future man" write for the Moslemische Revue? His contribution was titled "Does Islam 'lack modernity'? - A parallel between the old religion and Europe of the present." ${ }^{82}$ In its pages, Fischer, like von Ehrenfels, sets off to find parallels between Islam and examples of modern European-ness but unlike von Ehrenfels, in Fischer's world 'modern' is everything that Nazi ideology stands for: Islam forbids alcohol? No problem! “The Führer of the German

\footnotetext{
79 Moslemische Revue (1930): 98-105.

$80 \quad$ Reiss, Der Orientalist, 363 .

81 Moslemische Revue (1934): 62. For 1934, we find Fischer's name on the DMG board, proof that for some time at least he was an active member.

$82 \quad$ Moslemisch Revue (1934): 62-73.
} 
people does not take one single drop!" 83 or, "Does Islam lack progress? Certainly not! Europe adopts more and more Islamic thought." ${ }^{84}$ Instead of intellect and liberalism, Fischer writes, Nazism propagates hygiene, sports, and attachment to the earth; instead of individualism, it cultivates group experience. ${ }^{85} \mathrm{To}$ Fischer, this is what Islam is all about: "Not modern? Never! Not civilized? Never! Otherwise, our statesmen would not act in an Islamic way. Are you not modern? Am I perhaps not modern?"86

\section{Shaping Religious Modernity}

From our visit to the photo gallery of the Ahmadiyya mission journal, it becomes clear that 'their' new Muslims did not adopt any visible Islamic attributes because, first, it was the Ahmadiyya view that "becoming a Muslim does not require a transformation," and second, because the Germans thought that their entry necessitated a range of changes for Islam as a matter of course. For the circle of Muslim émigrés who gathered in the IGB, the German enthusiasm to join Islam thus acquired an uncomfortable edge. In their view, the way converts in the Ahmadiyya mosque communicated about Islam and the courses to progress they suggested, were not only unrecognizable to 'real' Muslims, but they should be downright rejected.

Early in 1937, Habibur Rahman sent a 10-page paper to the Foreign Office in which he once again summarized his grievances against the Ahmadiyya. ${ }^{87}$ The Ahmadiyya, he states, present a serious disturbance in Berlin, not only because they possess the only mosque but also because the ways in which they shape Islamic communication angers IG B Muslims to the extent that they refuse to pray there. "Disturbing" is the "shameless, indiscriminate mission activity," which attracts "criminal elements such as Jewish and communist agitators." 88 By way of solution, Rahman suggests that the influx of converts should be strictly controlled, and that this control should be based on the rules already laid down in the renewed founding protocol of the IG B. ${ }^{89}$ This document stipulates that converts should not only give written proof of

\footnotetext{
$83 \quad$ Moslemisch Revue (1934): 67.

84 Moslemisch Revue (1934): 71.

85 Ibid.

86 Moslemisch Revue (1934): 73.

87 AA/4 (22 March 1937): 1.

88 Ibid., 7-8.

89 AA/4 (10 July 1936), protocol in attachment.
} 
their exit from their former communities and their entries into the Muslim community, as Tschelebi already decreed, but they must also prove "flawless conduct for a period of two years," give "written consent to adopt a Muslim name," and establish "serious attempts to acquire one of the oriental languages." 90

Why did Rahman bear down on converts in a manner that seems designed to prevent them from becoming Muslim at all? Despite the tirade of hate with which the author attacked his opponent, despite his obvious desire to obtain the mosque, there is an element in this text that touches upon the very nature of religious renewal itself.

In an article headed "We Require a Mosque in Berlin," appearing some weeks later in The Star of India, he or one of his circle explained the rationale behind his statement. For example, the author deplores the sense of foreignness one may feel when visiting the discussion circle in the Ahmadiyya mosque, and when participating in prayer he even detects something decidedly un-Islamic:

If (...) a Muslim pays a visit to one of the conferences which are held on Friday evening in the mosque or in the house of the Imam, he will probably find there a Christian lady or gentleman delivering a speech about beautiful landscapes in foreign countries, about the political situation in India, about Persian Poets and all sorts and kinds of subjects of more or less general interest. Real Islamic instructions and information are hardly ever given and if so, the subject will mostly serve to cover up the difference between Islam and Christianity. ${ }^{91}$

Partaking in the Friday prayer presents another shock: "To take part at the congregational Friday Prayer is impossible for an orthodox Muslim.... The few Muslims see themselves, during the prayer, surrounded by a crowd of nonMuslims, sitting on benches and watching 'the performance."'92

This, the author concludes, cannot be true Islam. These performances definitely give a false impression of what real Islam was about: "Under those circumstances, the Berlin mosque...can never be the center of the Muslim community."93

Whoever wrote this article certainly had been an intimate observer of the comings and goings in the Ahmadiyya mosque and mission house. However, in

\begin{tabular}{ll}
\hline 90 & Ibid. \\
91 & AA/4 (21 April 1937). Newspaper clipping in attachment. \\
92 & Ibid. \\
93 & Ibid.
\end{tabular}


contrast to the move toward modernization, which both Europe and the Muslim world overwhelmingly desired, Habibur Rahman and those around him seem to have held up a frozen, timeless image of Islam, which they 'knew' by right of birth. Acting along the lines of purity and danger (Mary Douglas), this circle set out to re-draw its borders without even discussing their views openly. At least we do not find any evidence of such discussions among the many comments on lectures held in the mosque. Rahman's main instrument of communication exhausted itself in a rhetoric of hate, of which many instances survive.

Unfortunately the times were propitious for him. Muslim émigrés in Berlin who suspected converts of eroding 'their' religion expected Nazis to support them. But their extensive cooperation during the war falls outside the scope of this contribution; this is treated elsewhere. ${ }^{94}$

There exists a group photograph in the Moslemische Revue, dating 1936, in which we see the DMG community listening to a sermon in the mosque. ${ }^{95}$ The viewer beholds European men and women sitting on wooden chairs in close proximity to one another. Although it seems to be cold and the congregation huddles in winter coats, many of the women are bare headed, as are the men. In front of the pulpit one catches a glimpse of two men in Arab headgear sitting on the floor. Is this what our author is talking about? On close inspection, the congregation gives a vaguely Lutheran impression but there is also no doubt that these are Muslims celebrating the annual Eid festival. What can be seen then is an instance of modern Muslim ritual communication. It is but one instance of the bridge the Ahmadiyya tried to build between East and West, Christianity and Islam, between the need for modernization in the Muslim world and European visions of progress and of the "future man."

\section{Conclusion}

Religion is not a primordial entity thrown into the world from outer space. In the eyes of its adherents it may be inspired, even ruled by divine power. But the ways in which this inspiration takes form is entirely a matter of human creativity. Every religion has appeared in a specific societal setting, creating a tradition that shaped social communication, and in its turn was shaped by society. As societies change, reform and renewal of that tradition constitute a necessary and never-finished task.

94 Jonker, Missionising Europe.

95 Moslemische Revue (1936): 1. 
In this contribution I have shown that in Berlin Muslim missionaries from British India fostered different ideas of how to modernize their home country; they envisioned a struggle that involved the modernization of Islam as a central feature and they invited the Germans to join in this effort. In the early 1920s, when revolutionary movements still held Germany in their grip, Kheiri's invitation to 'world revolution' attracted a circle of German and eastern European students, intellectuals, and artists. In a very different fashion, Sadrud-Din approached modernization from the viewpoint of personal progress: all the German seekers had to do was find the 'right' roots in themselves.

But missionaries were not alone in searching for change. Between the Great War and the chaos that engulfed the world in 1939, many Germans also desperately groped for ideas that would allow them to help shape the future in ways they deemed appropriate, in ways that utilized pacifism, that would bring progress, bridge the East and West, and represent a meeting of minds, foster personal well-being, and provide for peoples' spiritual needs. Borrowing from, even transgressing on other religions was only one means to this end. Such Germans considered "being modern" a method of achieving personal progress and a shield against all those who wanted to turn back the clock and re-establish the traditions and power structures of a bygone age.

In the tumultuous years at the end of the Weimar era, when an aggressive authoritarian form of modernity took hold of the masses, this "religious market" was put to the test. It was not only the Indian Muslims in Berlin; the Arab, Afghan, and Tatar Muslims were also focused on reforming their homelands and making them politically independent. Islam was assigned very different roles in that process. The Muslim émigrés who gathered in the IGB perceived their religion as something that bonded them together, but which did not necessarily call for outward change. By siding with the Nazi regime in an attempt to gain power, the IGB even tried to ward off renewal and withdrew to a primordial vision of 'pure Islam.'

In contrast, Ahmadiyya Muslims tried to build a bridge between different cultural traditions with the aim of fertilizing and reforming both Christianity and Islam. In the interwar years this was their hallmark of religious modernity. Acting in a political constellation in which missionaries and converts embraced personal progress as the essence of modernity, conversion itself became a two-way process. And herein lies the meaning of Ahmadiyya activity for European (trans)cultural history: In their attempt to cross the gulf between East and West, missionaries smoothed the way, borrowing from, and adapting to western thought wherever it was of use. By paralleling religious with intellectual exchange, missionaries allowed their converts to adapt Islam's foreign 
knowledge, ritual, and moral traditions to more familiar patterns. What they shared, their common ground so to speak, was a taste for experiment. In a joint effort, missionaries and converts created a totally different image of Islam, one in which Germans marveled and in which they were able to find consolation.

In retrospect, Muhammed Ali's welcome of the new regime in 1933 because of its "tackling the wealth and sex problem" may sound naïve in the face of the violence that followed. But how was he to know? Did the DMG realize it was playing with fire? Individual members continued to believe that European civilization would be changed by re-modeling the self and shaping a Muslim "future man"; this was a vision strong enough to keep liberals, fascists, and Jews assembled under one roof. The bond lasted until the Nazi element took over in 1935. Taking this into account, the interaction between Muslim missionaries and their host society engendered fresh ideas and knowledge transfers in many different directions. Modernization and progress were the key words around which communication circulated; converts who had surmounted cultural borders simply continued to pursue these central notions in their search for salvation. Muslims like Habibur Rahman, who clung to a primordial image of religion, probably never noticed the momentum and urgency of their quest.

\section{Bibliography}

\section{Primary and Archival Sources}

Muslim (Mission) Journals

Die Islamische Gegenwart. Monatszeitschrift für die Zeitgeschichte des Islam, edited by M. Nafi Tschelebi and Muhammed Hassan Hoffmann. Berlin: 1927-1929.

Der Islam. Ein Wegweiser zur Rettung und zum Wiederaufbau, edited by Jabbar Kheiri and Sattar Kheiri. Berlin: 1922-1923.

Moslemische Revue, edited by Sadr-ud-Din, F.K. Khan Durrani, and S.M. Abdullah.

Berlin: 1924-1939.

\section{Registry Files (VR)}

DGI = Deutsche Gesellschaft für Islamkunde e.V. :VR 26349 (1912-).

DMG = Die Deutsch-Moslemische Gesellschaft e.V. :VR Nr. 8769 (1930-).

IG B = Die Islamische Gemeinde zu Berlin e.V. : VR B Rep. 042 / Nr. 26590 (1922-).

IIB = Islam-Institut zu Berlin e.V. : VR 12354 (1939-) and 95 VR 12941 (1942-).

Sufi $=$ Sufi-Bewegung e.V. 94 : VR 4635 (1925-). 


\section{German Foreign Office (AA)}

AA/1 = AA PA R 782.40. Abteilung III / Akten betreffend Kirchen- und Religionsgemeinschaften / Islam, Volume 1: 1924-1928.

AA/2 = AA PA R 782.41. Abteilung III / Akten betreffend Religions- und Kirchenwesen / Islam, Volume 2: 1928-1931.

AA/3 = AA PA R 782.42. Abteilung III / Akten betreffend Kirchen- und Religionsgemeinschaften, Islam, Volume 3: 1932-1936.

AA/4 = AA PA R 104.801. Politische Abteilung /Akten betreffend Religions- und Kirchenwesen, Islam, 1936-1939.

AA $/ 5$ = AA 60.675 / Akten betreffend Indien, 1942.

Ahmadiyya Mosque Archive (AMA)

AMA / Interwar (1930-1939).

AMA / Post-war (1946-1949).

\section{Bundesarchiv (Barch)}

Abt. Berlin: NSDAP Register

\section{Secondary Sources}

Achcar, Gilbert. Les Arabes et la Shoah. Paris: Actes sud, 2009.

Asad, Muhammad. The Road to Mecca. New York: Simon \& Schuster, 1993 [1954].

Aspetsberger, Friedbert. 'Arnolt Bronnen.' Biografie. Wien-Köln-Weimar: Böhlau, 1995 .

Bauschinger, Sigrid. "The Berlin Moderns: Else Lasker-Schüler and 'Café Culture.” In Berlin Metropolis, edited by Emily D. Bilsky, 58-102. New York: Jewish Museum, 2000.

Behnam, Jamshid. “'Iranshär' and 'Iranshär, Hosayn Kazemzada.” Encyclopedia Iranica (2006), 13:535-536 and 537-539.

Burbank, Jane and Frederick Cooper. "War and Revolution in a World of Empires: 1914-1945." In Empires in World History, edited by Jane Burbank et al., 369-413. Princeton, NJ: Princeton University Press, 2010.

Conze, Vanessa. Das Europa der Deutschen: Ideen von Europa in Deutschland zwischen Reichstradition und Westorientierung (1920-1970). Munich: Oldenbourg Wissenschaftsverlag, 2005.

Doering-Manteufel, Anselm. "Suchbewegungen in der Moderne. Religion im politischen Feld der Weimarer Republik." In Religion und Gesellschaft. Europa im 20. Jahrhundert, edited by Friedrich Graf and Klaus Große Kracht, 175-202. Köln/ Weimar/Wien: Böhlau, 2007.

Dohrn, Verena and Gertrud Pickhan. Transit und Transformation. Osteuropäischjüdische Migranten in Berlin 1918-1939. Göttingen: Wallstein, 2012. 
Esad Bey. Öl und Blut im Orient. Meine Kindheit in Baku und meine haarsträubende Flucht durch den Kaukasus. Munich: Deutsche Verlagsanstalt, 1930.

Fuhrmann, Wilfried. "Plagiat, Lüge oder Vertrauen? Wo ist Essad-Bey?" Accessible online: www.essadbey.de, 2009.

Giljazov, Iskander. Muslime in Deutschland: Von den zwanziger Jahren zum 'Islamische Faktor'während des 2. Weltkrieges (MS, Höpp Archive), 1989.

Hiller, Kurt. Leben gegen die Zeit. Erinnerungen. Hamburg: Rowohlt, 1969.

Hobohm, Mohammed, A. Neuanfänge muslimischen Gemeindelebens nach dem Krieg, 2000. Available online at Geschichte des Islams in Deutschland, accessed 19 April 2015: http://web.archive.org/ web/20070129062534.

Hobsbawn, Eric. The Age of Extremes. A History of the World 1914-1991. New York: Vintage Books, 1994.

Höpp, Gerhard. Arabische und islamische Periodika in Berlin und Brandenburg 1915-1945. Geschichtlicher Abriß und Bibliographie. Berlin: Das Arabische Buch, 1994.

Höpp, Gerhard. Mohammed Essad Bey: Nur Orient für Europäer? Unpublished Ms, private archive Hoepp, in Zentrum Moderner Orient, Berlin, 1995.

Höpp, Gerhard. "Noussimbaum wird Essad Bey. Annäherung an eine Biographie zwischen den Kulturen." Moslemische Revue (1996): 18-26.

Höpp, Gerhard. 'Die Sache ist von immenser Wichtigkeit...' Arabische Studenten in Berlin. Unpublished MS, private archive Hoepp, in Zentrum Moderner Orient, Berlin, 1990.

Höpp, Gerhard. "Zwischen Moschee und Demonstration. Muslime in Berlin, 1922-1930." Moslemische Revue (1990/3): 135-146, (1990/4): 230-223, (1991/1), 12-19.

Horne, John and Alan Kramer. German Atrocities: A History of Denial. New Haven and London: Yale University Press, 2001.

Jonker, Gerdien. "The Dynamics of Adaptive Globalization: Muslim Missionaries in Weimar Berlin." Entangled Religions (2014): 115-158.

Jonker, Gerdien. "A Laboratory of Modernity—The Ahmadiyya Mission in Interwar Europe." Journal of Muslims in Europe (2014): 1-25.

Jonker, Gerdien. Missionizing Europe: The Ahmadiyya Quest for Religious Progress 1900-1965. Leiden: EJ Brill, 2015.

Kheiri, Abdul Jabbar. Sowjet-Rußland und die Völker der Welt. Petrograd: Verlag Kommunistische Internationale, 1924.

Kilcher, Andreas B. "Konversion als Erzählung." In Treten Sie ein! Treten Sie aus! Warum Menschen ihre Religion wechseln, edited by Hanno Loewy, Fritz Backhaus, and Bernhard Purin, 50-64. Berlin: Parthas, 2012.

Klöckner, Michael and Udo Tworuschka. Religionen in Deutschland. Kirchen, GlaubensGemeinschaften, Sekten. Munich: Olzog Verlag, 1994.

Kuhlmann, Jan. Subhas Chandra Bose und die Indienpolitik der Achsenmächte Zeitgeschichte. Berlin: Verlag Hans Schiler, 2003.

Lamont, Michele. "The Study of Boundaries Across the Social Sciences." Annual Review of Sociology 28 (2002): 167-195. 
Linse, Ulrich. “Lebensreform und Reformreligionen." In Die Lebensreform. Entwürfe der Neugestaltung von Leben und Kunst um 19oo, edited by Kai Buchholz et al., 193-199. Darmstadt: Haeusser-media, 2001.

Maser, Werner. Adolf Hitler. Mein Kampf. Geschichte. Auszüge. Kommentare. Rastatt: Moewig, 1981.

Pollack, Detlev. "Was ist Konversion?" In Treten Sie ein! Treten Sie aus! Warum Menschen ihre Religion wechseln, edited by Hanno Loewy, et al., 38-50. Berlin: Parthas, 2012.

Reiss, Tom. Der Orientalist. Auf den Spuren von Esad Bey. Berlin: Osburg Verlag, 2008. Salomon, Ernst von. Der Fragebogen. Hamburg: Rowohlt, 1961.

Schlögel, Karl. Das russische Berlin. Ostbahnhof Europas. Munich: Panthon, 2007. Van Koningsveld, Pieter Sjoerd. "The Training of Imams by the Third Reich." In The Study of Religion and the Training of Muslim Clergy in Europe: Academic and Religious Freedom in the 21th Century, edited by Willem B. Drees and Sjoerd van Koningsveld, 333-368. Leiden: Leiden University Press, 2008.

Windhager, Günther. Leopold Weiss alias Muhammad Asad. Wien: Böhlau, 2003.

Zander, Helmut. "Die Theosophie im Kontext weltanschaulicher Pluralisierung im 19. Jahrhundert." In Anthroposophie in Deutschland. Theosophische Weltanschauung und gesellschaftliche Praxis 1884-1945, 33-51. Göttingen:Vandenhoeck and Ruprecht, 2007 . 


\title{
Salafiyya, Ahmadiyya, and European Converts to Islam in the Interwar Period
}

\author{
Umar Ryad
}

\section{Introduction}

The religious conflict between the Ahmadiyya Muslims and so-called "mainstream" Islam is as old as the establishment of this movement in India by Mirza Ghulam Ahmad (1835-1908) in the late nineteenth century. The heated debates that took place between the Ahmadis and other Muslims included both theological and political issues, such as the seal of the prophecy of the Prophet Muhammed, the claim that Ghulam Ahmad was the Promised Messiah, and the "collaboration" of the Ahmadiyya with British colonial authorities. ${ }^{1}$ In the interwar period the Ahmadiyya occupied a pioneering place as a Muslim missionary movement in Europe; they established mosques, printed missionary publications in a variety of European languages, and attracted many European converts to Islam. These converts played prominent trans-local, as well as transnational and transcultural roles in the development of modern Islamic thought in that era. Their new link with Islam should be seen as ingrained in the zeitgeist that inspired a few rich, mostly well-educated Europeans to adopt Islam as a new faith as a result of their search for spiritual pathways beyond their original culture and beliefs. In England, France, and Germany, many European converts became zealous in spreading Islam in Europe. ${ }^{2}$

The success of Ahmadiyya missionary work in interwar Europe reached the Muslim world and caused huge controversies among Muslim scholars, especially within the so-called Salafi reformist movement led by the well-known Muslim reformist scholar Muhammad Rashīd Riḍā (1865-1935) and popularized in his journal al-Manār [The lighthouse, 1898-1935]. We place these writers under the rubric "Salafiyya" because they approached Islam in the modern age by means of a reformist call to return to the early salaf (forefathers).

1 See, for example, H. Hanson, "Jihad and the Ahmadiyya Muslim Community: Nonviolent Efforts to Promote Islam in the Contemporary World," Nova Religio 11, no. 2 (2007): 77-93; Spencer Lavan, "Polemics and Conflict in Ahmadiyya History: The 'Ulema, the Missionaries, and the British (1898)," Muslim World 62, no. 3 (1972): 283-303.

2 Nathalie Clayer and Eric Germain (eds.), Islam in Interwar Europe (London: Hurst, 2008), 8-9.

(C) UMAR RYAD, 2016 | DOI 10.1163/9789004301979_004

This is an open access chapter distributed under the terms of the Creative Commons

Attribution-Noncommercial 3.0 Unported (CC-BY-NC 3.0) License. 
Although these Salafi groups had sectarian differences with the Ahmadiyya, there were also commonalities in terms of their discourse on Islamic reform and modernity. Amid these Salafi-Ahmadi doctrinal and sectarian divisions, news about the Ahmadiyya success in propagating Islam reached these circles (especially in Egypt) and put these Salafì writers in a quandary between their uncompromising sectarian differences with the Ahmadiyya and their desire to welcome the Ahmadiyya's success in converting Europeans to Islam.

Most of these Salafi writers were aware of the split within the Ahmadiyya movement, and that most of the work in Europe was achieved by the Ahmadiyya Anjuman-i Isha'at-i Islam (Ahmadiyya Society for the Propagation of Islam) under the leadership of Mawlana Muhammad 'Alī (1874-1951). Muhammad 'Alī was a sincere follower of Mirza Ghulam Ahmad and affirmed his position as a mujaddid (reformer), but not as a "Promised Mahdi or Messiah." Others also took this position: the Lahore mission in London, for example, was keen on distinguishing themselves from the Qadiyani branch of the Ahmadiyya led by Mirza Ghulam Ahmad's son in Qadiyan, who insisted that his father was the "Promised Messiah."

The historical role of the Ahmadiyya in the interwar period has been studied from the perspective of their local activities in Muslim communities in Europe. For example, the Woking Mission and mosque in South West London (established in 1914) became a "symbolic and organizational centrality in the inter-war period for British Islam,"3 when its first leader, the well-known Muslim lawyer Khwaja Kamal-ud-Din (1870-1932) set up a literary trust to publish their magazine and other missionary tracts. ${ }^{4}$ Through this mission, Islam appealed to many British figures, such as Baron Lord Headley (1855-1955) who founded the British Muslim Society in 1914, and Abdullah Yusuf Ali (1872-1953), a well-known translator of the Qur'ān, to name just a few. ${ }^{5}$ In April 1925, a "Lahori" mosque (i.e., aligned with the main Ahmadiyya) which was closely connected to the Woking mosque was established in Berlin. ${ }^{6}$ In 1924, the foundation stone for a Qadiyani mosque was laid in the Southfields suburb of London; the mosque was officially inaugurated in 1926. The Woking and Southfields mosques approached their propaganda in similar ways. In

3 See, K. Humayun Ansari, "The Woking Mosque: A Case Study of Muslim Engagement with British Society since 1889," Immigrants \& Minorities 21, no. 3 (2002), 7.

4 Eric Germain, "The First Muslim Mission on a European Scale: Ahmadi-Lahori Networks in the Interwar Period," in Islam in Inter-War Europe, ed. Nathalie Clayer and Eric Germain (London: C. Hurst \& Co., 2008), 89-91.

5 Ansari, "The Woking Mosque," 8.

6 See Gerdien Jonker's chapter in this volume. 
Germain's view, at the grassroots level the boundary between the two branches of the Ahmadiyya was somehow blurrred. Despite their competition, the Qadiyani mosque advertised the activities of the Lahori, and their newspapers had subscribers in common. In London, some people attended religious celebrations in Woking as well as in Southfields. This confusion was probably more convenient for the Qadiyani branch, since their work was still beginning in Europe. ${ }^{7}$

To a certain extent, the faith of the Lahore group in Ghulam Ahmad as a reformer made them less controversial than the Qadiyanis in some Salafi groups. It should be also emphasized that the Lahori Ahmadiyya missionaries in interwar Europe tried to down play these sectarian conflicts by adapting their message to their audiences in Europe on the one hand, and by seeking ways to present a positive image of themselves and their work in Europe to the Muslim public outside Europe. In 1929 James Thayer Addison described the Lahore group as more clever than sincere with regard to their origin, since they were

reluctant to admit any connection with the Ahmadiyya movement. Its leaders, especially in England, are eager to adapt their message to the convictions or the fashions of the present hour and to exploit the ignorance of their audience by making any assertions that will favor their cause. Intellectually more acceptable than the Qadiani, they inspire less respect, for one usually prefers the naive and narrow-minded to the sophisticated and slippery. ${ }^{8}$

In his well-documented work on British converts in the period from $185^{\circ}$ to 1950, Jamie Gilham gives a few local examples how British converts to Islam, who were engaged in the Ahmadiyya circles, reacted to sectarianism during that period. After World War I, early British converts repeatedly confirmed in their writings that the Ahmadiyya mission was part of the wider umma; but tensions about the Ahmadiyya differences and leadership began to appear again throughout 1930s. ${ }^{9}$ Around the same time, these conflicts reached the Muslim world. In addition to their involvement in the Ahmadiyya mission, during the interwar period European converts were active in a wider pan-Islamic

7 Germain, "The First," 102-103.

8 James Thayer Addison, "The Ahmadiya Movement and Its Western Propaganda," Harvard Theological Review 22, no. 1 (January 1929), 1.

9 Jamie Gilham, Loyal Enemies: British Converts to Islam 1850-1950 (London: Hurst, 2014), 200-205. 
Salafì network of associates, both inside and outside Europe. In particular, they took part in missionary work, in the translation movement of the Qur'àn in Europe, and in the Muslim intellectual and religious debates of that time. By such "transnational" connections, European converts were intermediaries, playing an "in-between" role between the European and Muslim cultures on the one hand, and between the Salafì reformist and the Ahmadiyya groups on the other. A deeper historical reading of these connections shows that despite their religious dissonance, the Ahmadiyya achievements in Europe and in relation to European converts created specific contact zones.

The position of European converts to Islam in the Salafi-Ahmadiyya disputes in the interwar period is remarkable. At the beginning of the 1930s, Muslim communities in India began an anti-Ahmadiyya campaign that included Ahmadiyya activities in Europe ${ }^{10}$ the debates that were generated had wide repercussions in various regions in the Muslim world and Europe. It is not surprising, given their reformist and puritan understanding of Islam, that the Salafiyya movement, in Cairo in particular, led one of the most outspoken anti-Ahmadiyya trends at the time. But, as we shall see, such negative attitudes were not always homogenous. On the one hand, we find that these Muslim reformists harshly attacked the Ahmadiyya doctrines, particularly their pacifistic view of jihad in Islam, but often praised their da'wa (missionary) activities in Europe on the other. We can also argue that the context of Muslims in Europe and the roles played by European converts to Islam sometimes obliged pan-Islamic reformist groups in interwar Europe to recognize and sometimes cooperate with the Ahmadiyya in serving common Islamic objectives.

In order to form a detailed picture of these conflicts, we highlight the attitudes of the Muslim reformist writers who contributed to Rashīd Riḍā's journal al-Manār and to the magazine al-Fath [The opening] founded by Riḍā's contemporary Syrian writer and activist Muhibb al-Dīn al-Khațib (1886-1969). Al-Fath, a weekly Islamic-oriented magazine, focused on the position of Islam and Muslim institutions in interwar Europe, especially on the work of European converts. Its editor can be considered among the Salafiyya because he supported the idea that Islam is not only restricted to ritual performance, but is a religion of "doctrine, worship, and rule." The magazine worked towards the removal of any "heretical elements" in the body of Islam. ${ }^{11}$ After Riḍā's death in

\footnotetext{
10 Germain, "The First Muslim," 103.

11 Amal N. Ghazar, "Power, Arabism and Islam in the Writings of Muhib ad-Din al-Khatib in al-Fath," Past Imperfect 6 (1997): 133-150·Also see Nimrod Hurvitz, "Muhibb ad-Din al-Khatib's Semitic Wave Theory and Pan-Arabism," Middle Eastern Studies 29, no. 1 (Jan.
} 
1935, al-Fath carried on Riḍā's legacy of the Salafiyya and flourished as a mouthpiece for many leading Salafī organizations and writers. However, as compared to Riḍā's "intellectual" Salafīsm, al-Fath carried this religious trend toward a more "populist" discourse. The activities of those European converts in their homelands were highlighted in a positive light by these journals in Egypt. Despite their adamant rejection of Ghulam Ahmad's "heterodox" theology, Salafĩ writers appreciated the religious work of the Ahmadiyya in interwar Europe and the conversion of many Europeans to Islam.

\section{Al-Manār and European Converts}

The conversion of European Christians to Islam was enthusiastically received by the early Salafiyya movement from the late nineteenth century on. They believed that Islam, unlike Christianity, could expand across the Muslim borders without any organized and collective missionary work. For example, Muhammad 'Abduh (1849-1905), the mufti of Egypt and Ridâ’s mentor, had direct contact with the prominent British convert Hajj Abdullah Browne (d. 1907). 'Abduh was impressed by Browne's "sincere worship and prayers," in English, which he found better than that of many who were born Muslim. ${ }^{12}$

Like 'Abduh, Ridā boasted about the conversion of Europeans to Islam. He saw their conversion as evidence of the failure of Christian missionary work in the Muslim world. ${ }^{13}$ He believed that most Muslims who abandoned Islam would never become real Christians, but rather turn into "atheists" or become antagonistic toward religion. Muslims mostly converted to Christianity out of poverty and need for financial support from missionaries, while in most cases western converts to Islam belonged to the elite classes in Europe. ${ }^{14}$

Riḍa was aware of the role of the Ahmadiyya's Woking mosque in converting Britons. Despite his positive tone regarding their work in Britain, al-Manār's strong anti-Ahmadiyya campaign never diminished. As early as 1901, Rị̣ā attacked Ghulam Ahmad for his claim to be a "shade for the Prophetic

1993): 118-134; Catherine Mayeur-Jaouen, "Les débuts d'une revue néo-salafiste: Muhibb al-Dîn al-Khatîb et Al-Fatḥ de 1926 à 1928," Revue des mondes musulmans et de la Méditerranée, 95-98 (April 2002), available online: http://remmm.revues.org/234. Umar Ryad, "Islamic Reformism and Great Britain: Rashid Riḍās Images as Reflected in the Journal al-Manār in Cairo," Islam and Christian Muslim Relations 21, no. 3 (2010), 273.

13 Umar Ryad, Islamic Reformism and Christianity: A Critical Reading of the Works of Muhammad Rashid Rid̄a and his Associates (1898-1935) (Leiden: Brill, 2009), 166-169; Ryad, "Islamic Reformism and Great Britain," 271.

Ryad, Islamic Reformism and Christianity, 160, 168-170. 


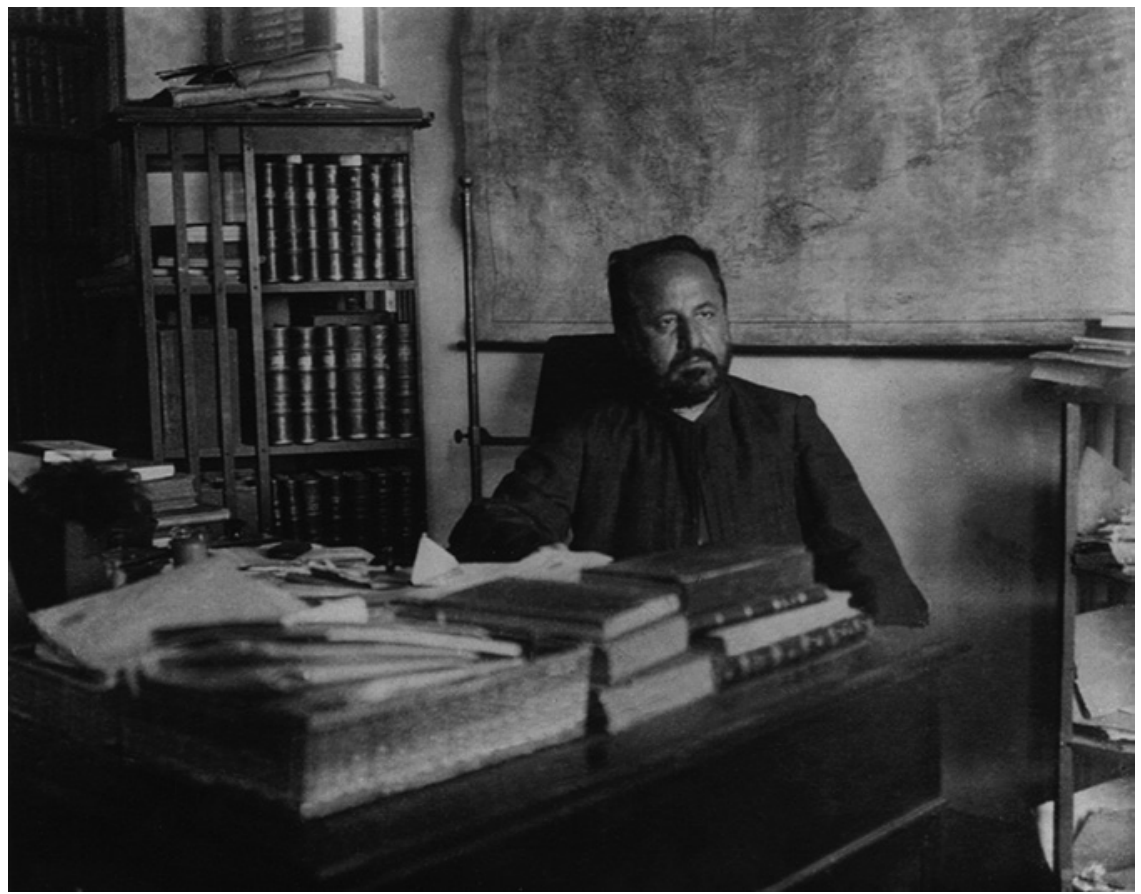

FIGURE 3.1 Sheikh Muhammad Rashìd Rid̄ā (1865-1935) in his Al-Manār Office in Cairo (Family archive in Cairo)

miracle."15 In response, Ghulam Ahmad depicted Riḍā as a "jealous" and "arrogant" scholar who, like many others, not only rejected the message, but fueled the dislike of Indian Muslims against him and his followers. ${ }^{16}$

15 See, Mirza Ghulam Ahmad, Ijāz al-masih (Tilford, Surrey, uk: al-Shirkat al-Islamiyya Limited, 2011), 34; available online: http://www.islamahmadiyya.net/pdf/ijaz_maseeh _full.pdf (accessed 20 March 2014); Rị̣ā wrote this in a fatwā to a question sent to al-Manār by a certain Aḥmad Muḥammad al-Alfī, a local Shafi'ì scholar in the town of Tukh in northern Egypt. Al-Manār, 4, no. 12 (31 Aug. 1901), 460-468.

16 Mirza Ghulam Ahmad, al-Hudā wa-l-tabșira liman yarā (Tilford, Surrey, uk: al-Shirkat al-Islamiyya Limited, 2011); available online: http://www.islamahmadiyya.net/books2. asp?book_key=67\&magazine =o (accessed 20 March 2014). also, al-Manār 5, no. 8 (22 July 1902), 317-320; al-Manār 5 no. 10 (20 Aug. 1902), 398-399. Cf. al-Manār 23, no. 1 (Jan. 1922), 33-35; al-Manār 31, no. 5 (Dec. 1930), 391-396; al-Manār 5, no. 19 (15 Jan. 1903), 789-791; also see al-Manār 24, no. 8 (Aug. 1923), 578-583; al-Manār 27, no. 1 (April 1926), 55-67. Also see the reactions of Mawlana Abu Wafa Sanaullah of Amritsar (1868-1948), one of the fiercest Indian opponents to Ghulam Ahmad, in al-Manār 27, no. 3 (June 1926), 238-239. 


\section{Cautious Appreciation: Lord Headley}

Despite harsh critiques of Ahmadiyya doctrines, al-Manār, in some instances, hailed the conversions of Europeans to Islam in the Woking mosque. The above-mentioned Baron Lord Headley and his conversion occupied a prominent place in al-Manār, despite Headley's known close connection with the Ahmadis in London.

Yet Headley's conversion was disputed in British society and Christian missionary circles, where it was seen as a form of "political Islam" because of his representation of Muslims in the House of Lords. Others claimed that he had not given up his former Christian beliefs completely, that in fact he maintained his faith in Jesus and his divine mission. ${ }^{17}$ Moreover, we know of two letters that Headley received from devout Christian friends who were shocked by his conversion to a religion "of sensuality and [in which] the Prophet had a great many wives."18

Many journals in the Muslim world became interested in these disputes regarding Headley's conversion to Islam. His response, "Why I became a Mohammedan," was fully translated into Arabic and published by al-Manār. In this response, Headley argued that "Islam and Christianity as taught by Christ himself are sister religions, only held apart by dogmas and technicalities which might be very well be dispensed with."19 In his comment on Headley's article, Ridā agreed with his "brother" Lord Headley that Islam is the Christianity which Jesus had called for. For Ridā, Headley's views resembled the response of Riḍā's pan-Islamic predecessor Jamāl al-Dīn al-Afghānī to the "failure" of Christian missions in India in the nineteenth-century when he said: "Islam is Christinaity with some additions." Islam confirms the same monotheistic faith and ethics that Jesus had called for, but invalidates what the Christians had

Ahmadiyya followers contended that the issue was unilateral and Mirza Ghulam Ahmad was not involved in this issue at all. See, for example, http://aaiil.org/text/acus/mga/ sanaullah.shtml (accessed 24 March 2014). See Riḍās debate with them during his stay in Lucknow (1912), al-Manār 31, no. 5 (Dec. 1930), 391-397; al-Manār 31, no. 6 (Jan. 1931), 479-48o; al-Manār 31 no. 7 (Feb. 1931), 559-56o; al-Manār 31, no. 10 (July 1931), 751-752.

As quoted in al-Manār 17, no. 1 (Dec. 1913), 34-40. Cf. al-Manār 28, no. 7 (Sept. 1927), 543-550. About Headley's conversion in the western press, see, for example, "Irish Peer turns Moslem," New York Times (16 Nov. 1913), 1; "Mohammedan Peer," Observer (16 Nov. 1913), 13; "Irish Peer converted to Mohametanism," Manchester Guardian (17 Nov. 1913), 9. Al-Manār 17, no. 1 (Dec. 1913), 34-40. Cf. Lord Rowland George Allanson Headley, "Why I became a Mohammedan," Observer (23 Nov. 1913), 4. 
later "corrupted." Rị̣ā believed that Europeans of his age would find Islam suitable, as it is the religion of "reason," "science," "civilization," and "peace." There were a number of impediments to their conversions to Islam, including Muslim sectarian strife, political animosities, the deteriorating state of Muslims, and their own unfamiliarity with the truth of their religion. In addition to these obstacles among Muslims, the Europeans lacked knowledge regarding Islam, the Arabic language, and were influenced by materialist sciences and practices, and by Christian myths and the cruelity of Papacy's authority in the past. These all led to the prevalent European aversion to religion in general. Ridâ̄'s words also addressed "westernized" Muslims, who mistakenly thought that Europeans were atheists. ${ }^{20}$

In addition to his joy in Headley's conversion, an unknown reader of al-Manār in London, wrote under the name muslim ghayr mutafarnij (a nonwesternized Muslim) that he appreciated the religious work of the Woking mosque and their periodicals, The Islamic Review and Muslim India, that served the Islamic message. In a short time, the Woking mosque was able to convert a good number of Europeans, including Elinor Annie Saxby, Ernst W. Oaten, and Amina Bamford. This so-called non-westernized Muslim translated Amina Bamford's conversion account that had been published in The Islamic Review, and submitted the translation for publication in Ridâ's journal. This was another message to Europeanized Muslims who had decided to abandon their religious beliefs and practices after mixing with Europeans. ${ }^{21}$ This London reader of al-Manār wished that a Muslim prince or a rich man would finance Rị̣ā’s Islamic missionary school, Dār al-Da'wa wa-l-Irshād (founded in 1912), so that it could serve as a training college for young Muslim preachers committed to propagate Islam in Europe. ${ }^{22}$ In response to the doubts expressed by some Muslims about the sincerity of European converts and their adherence to religious duties such as prayer and fasting, he replied that the Europeans' knowledge was based on their own research and reading, and their negligence of Islamic duties was no less controversial than that of some who were born Muslims and also neglected their religious duties. In his view, the Europeans' conversions was a boon to Islam in the west. ${ }^{23}$ In his response, Ridā expected more from Indian Muslims than Egyptians, at least with regard to the task of Islamic propaganda in Europe. The majority of rich Muslims were, however, in

\footnotetext{
20 al-Manār 17, no. 1 (Dec. 1913), 34-40.

21 Ryad, "Islamic Reformism and Great Britain," 278-279.

22 Ibid.

23 Al-Manār 18, no. 1 (Feb. 1913), 73-75.
} 
his view, too "stupid" and "villainous" to fund public projects, except when such projects would raise their status in the eyes of rulers and princes. ${ }^{24}$

In general, Riḍa agreed with Khwaja Kamal-ud-Din's "friends" and followers in Egypt and considered him a "moderate" follower of the Ahmadiyya. In 1923, Lord Headley, Kamal-ud-Din, and Abdul Mohye, the Arab mufti of the Woking Mosque (the Arab press gave him the title of the Mufti of the English Lands), passed through Egypt on their way to hajj. The trip was covered in a favorable light in the Islamic press in Egypt, including al-Manār. In Egyptian newspapers, Kamal-ud-Din found a suitable opportunity to defend the Lahore branch of the Ahmadiyya and their faith as being a trend close to "mainstream" Islam. Ridā was not able to meet them in order to discuss his doubts regarding the Ahmadiyya with Kamal-ud-Din in person. At this point, Riḍa found that Kamal-ud-Din's consideration of Ghulam Ahmad as merely a "reformer" was a good step by the Lahore branch towards the "true" Islam. ${ }^{25}$

Headley and his fellow pilgrims were highly regarded during this visit. Reception committees were organized in Port Said, Cairo, and Alexandria in order to honor Lord Headley in particular. From Port Said to Cairo and Alexandria, large gatherings appeared in train stations:

everywhere people would shake hands with Lord Headley and reverentially kiss the Khwaja's hands. Young and old joined together in lusty cheers of "Long live Lord Headley!" and "Long live Khwaja Kamal-udDin!" At such of the stations where stoppage was not less than three or four minutes the guests would speak a few words... ${ }^{26}$

In the Cairo railway station, a huge crowd gathered to welcome the guests. Headley and his friends were guests at the Heliopolis residence of the Egyptian notable and Sufi Sayyid Iḥsān al-Bakrī, who was well known to most English Muslims because of his stay in England and interest in the Woking mission activities. After the Friday prayer at al-Husayn Mosque, prayers and speeches were made in honor of the British Muslims by religious scholars and other notables, including Shaykh al-Sāwī, the president of the Cairo reception committee and the Naqīb al-Ashrāf (head of the descendants of the Prophet). A dinner banquette was organized for five hundred people that evening. Similar meetings were also organized in Alexandria, where Headley and his fellows

\footnotetext{
24 Ryad, "Islamic Reformism and Great Britain," 278-279.

25 Al-Manār 24, no. 8 (Aug. 1923), 583.

26 "Khwaja Kamal-ud-Din and Lord Headley in Egypt," Islamic Review (Sept. 1923), 301-307.
} 
were welcomed by religious scholars, merchants, politicians, and notables including the Egyptian prince 'Umar Tusun (1872-1944). ${ }^{27}$

The Egyptian press took great interest in this visit. The Egyptian daily al-Siyāsa, for example, portrayed a picture of the zeal of Egyptians in receiving these special guests from London. Egypt had not welcomed anyone with this much fanfare since the return of the well-known Egyptian politician Sad Zaghlūl (1858-1927) from exile. In al-Bakrīs residence, the journalist met Headley and made the following description: "His Lordship received me with his great polite and nice manners. On his head he wore the Egyptian tarbush (fez) put on his grey hair that reflected the redness [of the tarbush] in a beautiful rosy colour because of his white face and moving blue eyes." ${ }^{28}$

In that interview, Headley revealed the reasons he had converted to Islam. He said that as a child he had doubted many doctrines taught by the church. As he was not an entirely convinced Christian, he considered himself a unitarian, as did many others in Britain and the United States. Thus, even during the years before his official conversion, he considered himself a Muslim. While he was working as an engineer in India in 1883 he read a copy of the Quràn in English translation that had been given to him by a friend and he became impressed by the simplicity of the tenets of Islam. After reading the Qur'an, he discovered that he was a Muslim - and in fact he had not been exposed to any kind of missionary work. He stated that he delayed his public conversion because he did not want to hurt the feelings of the elderly members of his family. ${ }^{29}$

Riḍa did not agree with those Muslims who questioned the Englishman's sincere belief in Islam; he stated that "anybody reading this report with a heart should feel that it was said out of truth and sincerity."30 Furthermore, Riḍā said that it was no surprise that the majority of British people would disbelieve in the traditions of the church, since the British upbringing often takes into account the human fitra (pure disposition), and encourages independent thought. ${ }^{31}$ As a result of Headley's conversion, Rị̂a wished that "if Muslim missionaries went to Britain and the United States and revealed the swindle of politicians and...[Christian] missionaries, who caused enmity and animosity between Islam and Europe, the people of the two countries would actually

\footnotetext{
27 Ibid.

28 As quoted in al-Manār 24, no. 7 (July 1923), 555-559.

29 al-Manār 24, no. 7 (July 1923), 555-559.

30 Ibid.

31 Ibid.
} 
embrace Islam in droves." ${ }^{32}$ In addition, al-Manār translated and quoted some of Headley's works at length, including his A Western Awakening to Islam, in order to counter the arguments of "westernized" Muslims who criticized and distanced themselves from Islam. ${ }^{33}$

Meanwhile, despite Ridâ’s appreciation of the Lahore Ahmadiyya missionary work in Europe, he was critical of their translation of the Qurān into English. The Lahore Ahmadiyya tried to circulate Mawlana Muhammad 'Alī's English translation of the Qurān in Egypt and Syria, but their attempt was resisted by the religious institution of al-Azhar, Rị̣a himself, and his friend Shaykh Muștafā Najā (1852-1932), the mufti of Beirut. In his fatwā, Riḍā saw it as a "deviant" translation that contradicts the principles of Islam. He stated that the translation attempts to destroy Islam from within by disseminating the Ahmadiyya's "false" doctrines on revelation and by abrogating Qur'ānic rulings, such as jihad. ${ }^{34}$ In his view, Rị̣ā emphasized that Muhammad 'Alī intentionally distorted some verses related to the Messiah (al-masịh) in order to argue, based on these verses, that Ghulam Ahmad is the promised Messiah. Ridā urged Muslims not to rely on this translation, or on any other, to understand the Qur'ān, but rather to act according to its rulings in a direct manner. However, Ridā did believe that this translation and other Qurān translations could be used to invite non-Muslims to Islam, particularly those without knowledge of Arabic. ${ }^{35}$

Riḍâ's tone was inconsistent. With regard to the differences between the Lahore and Qadiyani branches in matters of creed ('aqida) and their religious work in Europe, Rịā argued that the Lahore movement agrees with other Muslims in general, except in specific issues related to the death of Jesus and the abrogation of certain verses of the Qurān. Despite their "great" sacrifices

32 As quoted in Ryad, Islamic Reformism and Christianity, 169.

33 al-Manār 26, no. 1 (April 1925), 6o-64 and also see al-Manār 29, no. 5 (Sept. 1928), 344-351. See also Riḍā's recommendation of Headley's works and his cooperation with Indian Muslims during the celebrations of the Prophet's birthday in the early 1930s, al-Manār 32, no. 3 (Feb. 1932), 190-192; al-Manār 32, no. 4 (April 1932), 280-283; al-Manār 34, no. 2 (June 1934), 129-139.

34 al-Manār 25, no. 10 (March 1925), 794-796.

35 al-Manār 29, no. 4 (July 1928), 268-271. See Mohamed Ali Mohamed Abou Sheishaa, "A Study of the Fatwā by Rashid Rị̂ā on the Translation of the Qur'an," Journal of the Society for Qur'ānic Studies 1, no. 1 (Oct. 2001), available online: (http://www.islamicwritings.org/ quran/language/a-study-of-the-fatwa-by-rashid-rida-on-the-translation-of-the-quran/). Cf. Moch Nur Ichwan, "Differing Responses to an Ahmadi Translation and Exegesis: The Holy Qur'ān in Egypt and Indonesia," Archipel 62 (2001): 143-161. 


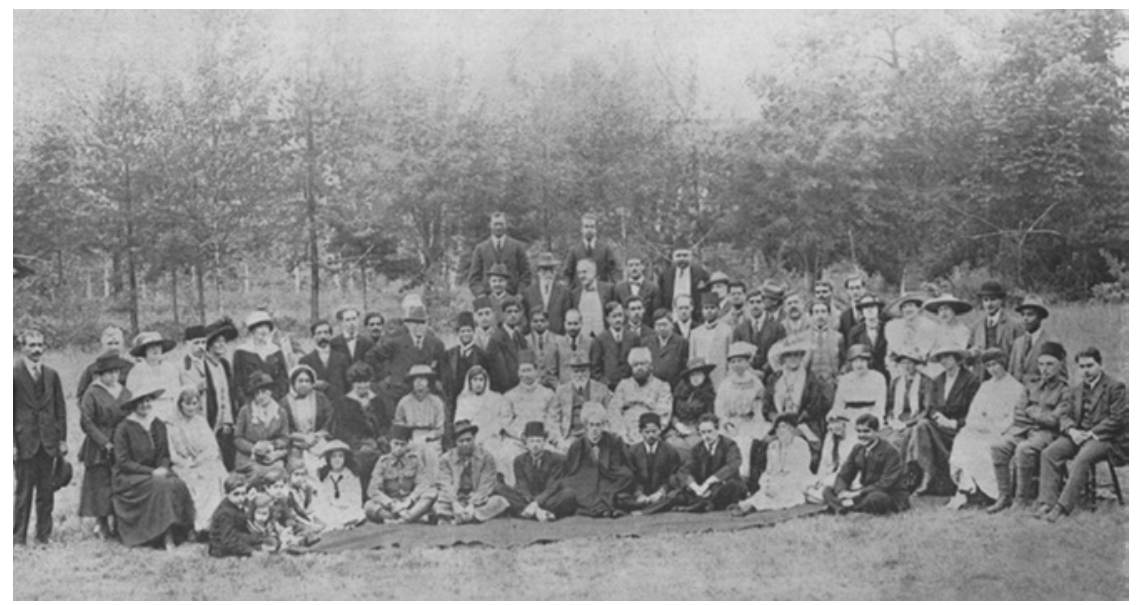

FIGURE 3.2 Id-ul-Fitr day at Woking, 10 July 1918 (The Islamic Review, August 1918) (from the website of the Ahmadiyya Anjuman Ish'at Islam Lahore (U.K.), Wembley, London)

for Islam in India and Europe, Riḍa finally concluded that the Ahmadis of both branches were followers of falsehood $(b \bar{a} t ̦ i l) .{ }^{36}$

Nevertheless, it is strange that Ridā utterly dismissed Kamal-ud-Din from the Ahmadiyya movement. After Khawaja Kamal-ud-Din's death, Riḍa eulogized him for his service for Islam in Europe. A brief biography of Kamal-ud-Din was soon published in al-Manār by Khwaja Abdul Ghani, secretary of the managing committee of the Woking Muslim Mission and Literary Trust in Lahore, as a token of appreciation. Rị̂̄a considered Kamal-ud-Din "the greatest missionary to Islam" in their age. Through his mission, he provided a great service to Islam by converting many high-class British, the most refined of them being Lord Headley. Although Kamal-ud-Din was known as a "moderate" follower of the Ahmadiyya, Rịā was told by many friends who were familiar with his work in Europe, that his activities and writings did not actually reflect any inclinations to the Ahmadiyya convictions as such. ${ }^{37}$

\section{Cutting All Connections with the Mirza: A Populist Salafî Voice}

Riḍā's journal does not reflect any further details about other contemporary European converts. As noted, by the late 1920s, al-Fath magazine had become

36 al-Manār 28, no. 7 (Sept. 1927), 543-550.

37 al-Manār 33, no. 2 (April 1933), 138. 
the mouthpiece of a more populist strand of Salafism. With regard to the Ahmadiyya and European converts in particular, its attitudes, like those of Riḍā, were not always consistent, but its tone was much harsher than al-Manār. Initially, some of the contributors to al-Fath were confused about the Ahmadiyya missionary work and doctrines and their success in Europe. Although Muhibb al-Dīn al-Khațib, the editor of al-Fath, did not express a positive view of the Ahmadiyya and its two branches, and remained very suspicious about their beliefs and missionary work; surprisingly, he allowed other writers to voice positive remarks about their work in Europe. However, throughout late 1930s, as we see, this appreciation was gradually replaced by a harsh campaign against the Ahmadiyya and their missionary work in Europe.

In 1932, the Irish-French convert Khalid Sheldrake (1888-1947), president of the Western Islamic Association in Britian (and also active in the Woking mission in London), ${ }^{38}$ sent a letter to al-Azhar in Cairo asking for a fatwa $\bar{a}$ on the permissibility of building and designing a new mosque in London that would be built by Christian builders in a modern European architectural style; this triggered a heated debate about the Ahmadiyya in al-Fath. The scholars, while aware of the sectarian disputes among Muslims in Britain at that time, replied in the affirmative. However, they advised the questioner to open this mosque to all Muslims, and not favor one sect over another. For the validity of their prayers in the West, the determination of the qibla (prayer direction) should be accurately measured. Al-Fath's editor was impressed by Sheldrake's work and urged Muslims to support him financially. Al-Khațib was probably not aware of Sheldrake's role in the Woking mosque at this time, since he emphatically requested him not to follow the example of the Woking mosque, whose doors were only open to the followers of the Ahmadiyya, at least in the eyes of the editor (this was not entirely correct). ${ }^{39}$

Interestingly, al-Fath was read in London. In response, a certain Ali Muhib, a Muslim living in London and a subscriber of the Ahmadiyya magazine The Islamic Review, immediately noted that this mosque played a great role in spreading Islam in the West and to him, all the preachers in the mosque, including Headley and Sheldrake himself, were Sunnīs. Others who did not follow the Ahmadiyya, such as Sultan Shah Jahan, Begum of Bhopal, ${ }^{40}$ offered

38 About his activities, "Moslem Funeral Service," Irish Times (1 Sept. 1928), 11; “40,00o For London Mosque," Manchester Guardian (27 Feb. 1928).

39 Al-Fath 6, no. 299 (1 July 1932), 15.

40 About him, see Saeedullah, The Life and Works of Muhammad Siddiq Hasan Khan, Nawab of Bhopal: 1248-1307/1832-189o, with a foreword by H.M. 'Abd al-Quddus Qasmi (Lahore: Sh. Muhammad Ashraf, 1973). 
generous donations to the mosque. Ali Muhib reminded al-Fath readers of Kamal-ud-Din's denial of any connection with the Qadiyani branch during his above-mentioned stay in Egypt. Nevertheless, unlike Riḍā, al-Fath did not trust Kamal-ud-Din's words, because he had not completely renounced the figure of Ghulam Ahmad, his claim of prophecy, and the presumed alliance between the Ahmadiyya and the British. ${ }^{41}$

Soon Prince 'Ādil Arslān (1887-1954), the brother of the well-known exiled Druze prince Shakīb Arslān (1869-1946), became involved in the debate by supporting Ali Muhib's arguments. ${ }^{42}$ During the Eid al-Fitr of 1930, 'Ādil Arslān saw that the majority of Muslims in London, even those of different nationalities, preferred to pray in the Woking mosque (despite its remote location from the city center) because of their hatred for the Qadiyani mosque. At the Woking mosque Arslān met with Lord Headley, other British Muslims, the deputy of the Egyptian consul and other Egyptian civil servants in the Egyptian consulate, Shaykh Ḥāfiz Wahba (1889-1967) (envoy extraordinary and minister plenipotentiary of the King of Hijaz in London), in addition to many Egyptians, Yemenis, Somalis, Syrians, Afghanis, and Indians. In a speech after the prayer, Lord Headley urged Muslims to unite and build a bigger mosque in the English capital; one like the Paris Mosque. This mosque should include rooms to house Muslim students and Muslim dignitaries visiting the city. 'Ādil Arslān strongly believed in Lord Headley's "undoubted and great sincerity" for Islam. Therefore, he stated, the Muslim press, including al-Fath, should support Headley's initiative to build this mosque as a meeting place to foster Muslim mutual support in Europe. Arslān was pleased to see Muslims wearing their oriental attire (such as turbans) on that day. Because the British loved such exotic scenes, he believed that the appearance of Muslims like this during the feast days might elevate the position of Muslims in their eyes. Friday prayers were also meant to teach people and answer their queries. "If you visited or resided in these lands," he wrote, "you would be assured that fairness belongs to the nature [of Europeans], particularly when they became persuaded of something."43

41 Al-Fath 7, no. 304 (5 Aug. 1932), 14.

42 'Ādil Arslān, "al-Dacwā ilā l-Islām fỉ l-gharb" [Calling for Islam in the west], al-Fath 7, no. 308 (2 Sept. 1932), 4-5. About him, see, for example, J. Honvault, "Speaking about Oneself when External Life is Ethically Primordial: The Diary of the Sryo-Lebanese Arab Nationalist 'Ādil Arslān (1887-1954)," in Many Ways of Speaking About the Self: Middle Eastern Ego-Documents in Arabic, Persian, and Turkish (14th-2oth Century), ed. Yavuz Köse and Ralf Herausgegeben von Elger (Wiesbaden: Harrassowitz, 2010), 47-58.

Arslān, "al-Da'wa," 4-5. 
'Ādil Arslān compared the missionary zeal of the Ahmadiyya in the West with Protestant and Catholic missions. In the United States, they converted a huge number of people. The only obstruction to spreading Islam among millions of Americans was race: the Ahmadiyya missionaries were not white. Because mainstream Muslims had failed to propagate the "true" essence of Islam, Arslān found no harm in such heterodox Muslim denominations preaching Islam in the West. ${ }^{44}$ Yet al-Fath's editor was still doubtful about the Ahmadiyya missionary work with its two branches in Europe and believed that even the work of Lahore members in London was "futile" as long as they did not recant their conviction in Mirza Ghulam Ahmad. Therefore, he strongly urged Sunnī Muslim dignitaries to support the building of a new mosque in London. ${ }^{45}$

In response to al-Fath's uncompromising stance, Mawlana Abdul-Majid (b. 1896), the acting imam of Woking Mosque (1932-1935), tried to clear the mosque's name of any misunderstanding by stressing that the Woking mosque was a center for the Islamic mission in England and was not limited to a specific sect of Islam. To prove his point, he enclosed a copy of The Islamic Review in which a photo of the Eid prayer was published, showing Muslims from various ethnic groups in the mosque. The prayer was led by the British convert William Burchell Bashyr Pickard. Other leading Sunnī Muslims, such as the mufti of Jerusalem Amīn al-Ḥusaynī and Shaykh Ḥāfiz Wahba, used to lead the prayers in the mosque as well. Abdul-Majid denied any connection with the other Qadiyani group: "I confirm to you that God had bestowed us unprecedented success in these lands only due to our vigorous efforts in propagating pure monotheism; and that the honorable Prophet Muhammad was the seal of prophecy. Our books are enough proofs that we really take distance from any [other] sects." 46

Again al-Khațîb noted that his magazine had avoided becoming involved in polemics with the Ahmadiyya who had been active in Europe for many years, but he was obliged to answer Ali Muhib's remarks. Although the nature of the Woking mosque and its differences with the Qadiyani branch was no secret, he

44 Ibid. Arslān mentioned that Muslims in New York, for instance, used to have their Eid collective prayer in an old theater. As they had neither competent religious guides nor good preachers to help them in their faith, Arslān wrote a letter to the Egyptian ministry of education, requesting that they to dispatch an Egyptian imam to lead the community, but he did not receive an answer.

45 Arslān, "al-Da'wa," 4-5.

46 "Masjid Woking fì London" [Woking mosque in London], al-Fath 7, no. 313 (7 Oct. 1932), 10-11. 


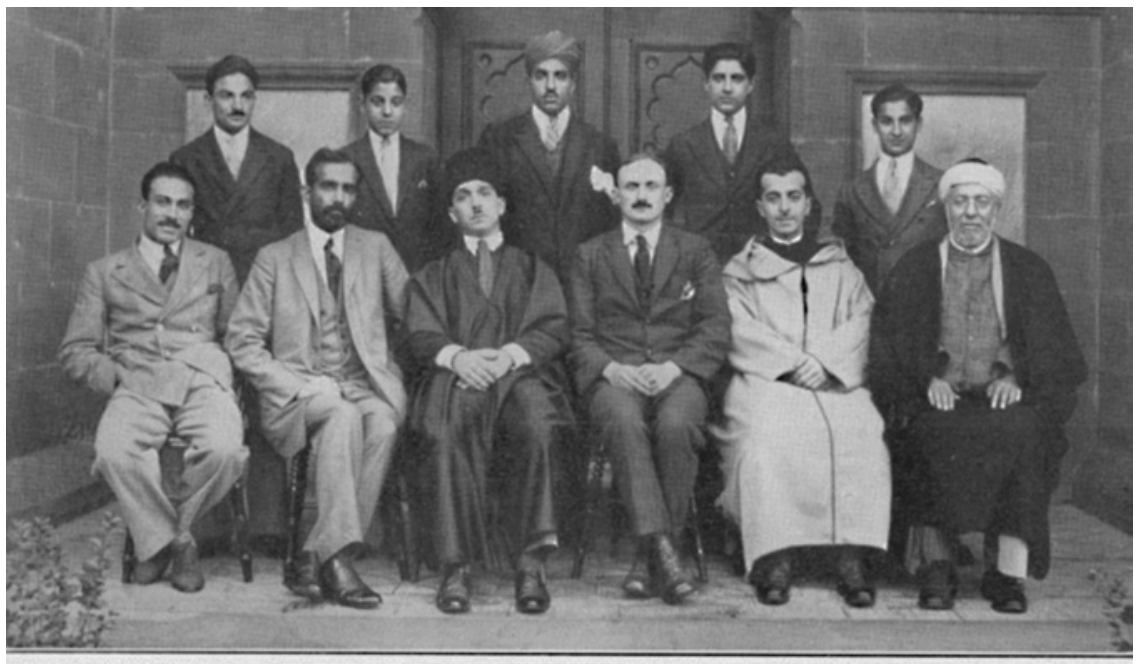

A Fraternal Muslim Group at the Mosque, Woking, with Mr. Omak Hubert C. Rhys Rankin, son of Lt.-Colonel Sis

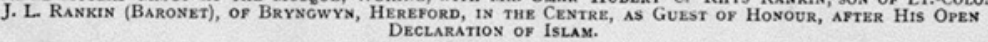

Standing (left to right):-Mr. Qadardad Khan (Secretary). Master Rahim. Mr. Gholam Mohd. Master Faruque. Master Ahmad. Sitting :-Mr. A. Kalique Khan, B.A. (Asst. Imám). Moulvi Abdul Majid, M.A. (Acting Imám). Mr. Abderrahman Hadji.

Mr. Omar Hubert C. Rhys Rankin. Mr. Muhamed Hadji. Prof. Abdul Mohyi (Arab), Mufti, The Mosque, Woking.

FIGURE 3.3 Muslim group at the Woking Mosque, with the convert Omar (later Sir Omar) Hubert Rankin, showing also Abdul Mohiy (The Islamic Review, January 1928) (from the website of the Ahmadiyya Anjuman Ish'at Islam Lahore (U.K.), Wembley, London)

insisted that Ghulam Ahmad was "the most corrupting person that had appeared in Islam in the last [nineteenth] century." ${ }^{77} \mathrm{He}$ urged his followers to sharpen their recantation of this "charlatan and his absurdity." ${ }^{8}$ In al-Khațîb's view, Abdul-Majid's claim that some prominent Muslim figures used to attend their mosque in London is not a valid argument. If al-Khațîb himself one day visited London, he would have no problem praying in the Woking mosque because, from an Islamic point of view, Muslims are allowed to pray anywhere on the earth, as it is all considered pure. ${ }^{49}$

\section{Ahmadiyya in Europe: Useful and Harmful}

At this stage, in Salafĩ circles a dichotomy was made between the positive impact of the Ahmadiyya in Europe and their doctrines, which were considered 
false. As the debate became heated, the Moroccan Salafĩ writer Taqīl-Dīn al-Hilālī (d. 1987), a close associate of Riḍā and Shakīb Arslān, became enthusiastic about the Ahmadiyya work in Europe; he defended European converts' "sincere zeal" for Islam. As a prolific writer in al-Fath, al-Hilāli was at this time in Lucknow where he was working as a lecturer of Arabic literature in Nadwatul-Ulama; and was learning English under the tutelage of a British Christian missionary in India. He also became an avid reader of the Ahmadiyya literature in English, especially the Lahori periodical The Light and the Qadiyani Review of Religion.

Some Muslims in India were doubtful about the sincerity of European converts because of their negligence of their religious duties, an issue that was earlier discussed in al-Manār. Al-Hilālī stated that while hundreds of millions of Muslims might pray and fast, they remained fragile and weak in the world and God's victory on earth will not be given to fasting and praying people only. For example, al-Hilālī deemed the works of the famous translator of the Qurān, Muhammad Marmaduke Pickthall (1875-1936), who was an active convert in the Woking mission, as equal to a "Muslim battalion" in the face of the enemies of Islam. His service for Islam in Europe was far better than the prayers of millions Muslims. He believed that a distinction should be made between the pious work of an individual Muslim and communal work that benefits the Muslim public interest. For al-Hilālī, prayers only benefit the one praying, while such communal acts as translating the Qurān are useful for all Muslims all over the world..$^{50}$

On the basis of his various readings in the Ahmadiyya literature in India, however, al-Hilālī reached a conclusion that the Ahmadiyya mission in Europe was useful and harmful at the same time. Their major and "amazing" religious work in Europe was even more successful than Christian missions in the Muslim world. In his view, because of their work, European converts now had access to some "true" Islamic tenets, even under the disguise of the "invented doctrines" of the Ahmadiyya. The Ahmadiyya, a tiny Muslim group, was capable of achieving what hundreds of millions of Muslims had failed to do for many years. He was sympathetic with their writings and even considered their defense of Islam in the West as a "real jihad" that should please every Muslim. ${ }^{51}$ His main critique of the Lahore Ahmadiyya magazine The Light was that it focused on their "odd" exegesis of the Qurān and their "unfounded" fatwās regarding specific theological issues such as the virgin birth of Jesus. But he distinguished their work from the Qadiyani branch, which remained, in his

50 Muhammad Taqī l-Dīn al-Hilālī, "Fī tarjamat al-Qurān aydan" [Regarding the translation of the Qur’ān, too], al-Fatḥ 6, no. 293 (6 April 1932), 4-7. 
view, more harmful, because of their unyielding conviction that Ghulam Ahmad was the "Promised Messiah." 52

Al-Hilāli ascribed the "usefulness" of the Ahmadiyya's missionary work to their potential "enlightening" of Europeans regarding Islam; they removed the "remnants of myths and fallacies" which "fanatic" Christian clergymen had been disseminating in Europe since the time of the Crusades. On the other hand, the Ahmadiyya work also influenced the image of European soldiers based in the Muslim East by revealing to them the reality of Islam and its Prophet. As a result, they might not take part in what al-Hilāi called the "destruction of Muslims" because of an inherited animosity against Islam. To remain a Christian or to convert to Islam through Ahmadiyya beliefs was for al-Hilālī equal. However, their efforts in removing misconceptions in European minds should be simply recognized as one of their advantages. ${ }^{53}$

In response, Mas'ūd 'Ālim al-Nadwī (1910-1956), co-founder of al-Piyā' magazine and one of al-Hilālì's associates in India, argued that this movement was neither useful to Islam, nor was their "charlatan" Ghulam Ahmad a reformer. ${ }^{54}$ Al-Khațib agreed and added that the Ahmadiyya was a separate "religion" completely opposed to Islam. Their work to convert non-Muslims was therefore useless because they were "corrupting" God's words and the Prophet's sayings with their own interpretations. In this case, one should combat their "damage" to Islam instead of praising them..$^{55}$

At the same time, the debate on the religious works of the Ahmadiyya reached other Muslim regions. For instance, the weekly newspaper Hadramaut launched an anti-Ahmadiyya campaign among the Arabic-speaking community in Indonesia. ${ }^{56}$ They fervently requested that Rashīd Riḍa and Shakīb Arslān stop praising the Ahmadiyya work in Europe; and stand against the Woking mosque and other centers in Europe instead of supporting them. It should be emphasized that Arslān defended the Ahmadiyya, and attended the

$5^{2}$ Taqī l-Dīn al-Hilālī, "al-Qadiyāniyyūn—Bađ̣u ma lahum wa-ma 'alayhim" [The Qadiyanis, the pros and cons], al-Fath 7 , no. 315 (21 Oct. 1932), 9-10.

53 Ibid., 9-10.

$54 \quad$ Al-Fath 7, no. 319 (17 Nov. 1932), 2.

55 Muhibb al-Dīn al-Khațīb, "al-Qadiyāniyya dīn yukhālif dīn al-Islām kamā anna al-Nașraniyya dīn yukhālif dīn al-Yahūd" [Qadiyaniyya: A religion that contradicts Islam just as Christianity contradicts the religion of the Jews], al-Fath 7, no. 320 (24 Nov. 1932), 1-3; Cf. idem, "Islāmunā wa-Islām al-Qadiyāniyyīn" [Our Islam and the Islam of the Qadiyanis], al-Fath 7, no. 322 (8 Dec. 1932), 1-3.

$5^{6}$ In 1932 a series of articles was published in Hadramaut under the title "al-Barāhin al-qat'iyya 'ala butlan al-niḥla al-Qadiyāniyya” [Decisive proofs about the invalidity of the Qadiyani sect] by the Palestinian Azhari shaykh Rabbāḥ Ḥassūna al-Khalīlī. 
inauguration of their mosque in Berlin. The Hadramaut warned that the Ahmadiyya often quoted Jamāl al-Dīn al-Afghānī and Muhammad 'Abduh, as well as al-Manār and Riḍā's Qurānic exegesis only in order to deceive Muslims about the real nature of their faith. ${ }^{57}$ In response, Zeki Kiram Hishmat (1886-1946), a Muslim living in Berlin and a friend of both Arslān and Riḍā,58 tried to refute the claims that Arslān was affiliated with the Ahmadiyya mission in Berlin as it was portrayed in the Indian press. It was true that Arslān used to visit their mosque, but this was only due to Arslān's aspiration to foster Muslim unity in Europe and eliminate any sectarian conflicts. Therefore, in 1932 the Berlin missionary imam of their mosque, S.M. Abdullah, invited Arslān to tea through Kiram, and they accepted. Strangely enough, Kiram implied that neither he nor Arslān had much previous knowledge about the Ahmadiyya's doctrines before this visit. In their publications, which they saw in the mosque, Ghulam Ahmad's adherence to the sharia was confirmed, as were his claims of prophecy and high esteem of the British Crown. ${ }^{59}$ Interestingly, most of the anti-Ahmadiyya campaign brochures were published by the Egyptian Mansur Rifaat in the 1920s at Kiram's publishing house in Berlin, the Morgen- und Abendland Verlag. ${ }^{60}$

\section{Come Back to "Mainstream" Islam}

Such indistinct views continued to circulate in Muslim Salafĩ circles in the early 1930s. Although most of them were aware of the doctrinal differences between the Lahore and Qadiyani branches, they insisted on alluding to both groups as "qadiyani." In reaction to Kiram's above-mentioned article, the

57 Weekblad Hadramaut, Soerabaja (Java), 318 (Feb. 1932).

$5^{8}$ About him, see, Umar Ryad, "From an Officer in the Ottoman Army to a Muslim Publicist and Armament Agent in Berlin: Zekî Hishmat Kirâm (1886-1946)," Bibliotheca Orientalis 63, nos. 3-4 (2006), 235-268.

59 Weekblad Hadramaut, 328 (14 May 1932).

6o For instance, the following by Mansur Rifaat, Die Ahmadia-Sekte: Ein Vorkämpfer für den englischen Imperialismus (Berlin, 1923); Der Verrat der Ahmadis an Heimat und Religion (Berlin, 1923); The Ahmadi Sect: Vanguard of the British Imperialism and the Greatest Danger to Islam, Convincing Evidence of their Duplicity (Berlin, 1923); Ahmadi Betrayal of Country and Religion (Berlin, 1923); Die Ahmadia Agenten: ein Rätsel. Werden sie tatsächlich von den deutschen Behörden unterstützt und beschützet? (Berlin, 1924); Vollständiger Zusammenbruch der Ahmadia-Sekte: Weitere Beweise für Ihre Tätigkeit als englische Agenten (Berlin, 1924); Total Demoralisation of the Ahmadia Sect: Further Evidence in regard to their Activities as British Agents and Menace to Islam (Berlin, 1924). 
Tunisian-Egyptian scholar and later Grand Shaykh of al-Azhar, Muhammad al-Khidir Husayn (1876-1958), branded the Lahore branch as "misguided." He stated that if they had confined the spread of their message to non-Muslims, its "danger" would have been less; their proselytizing work among non-Muslims was tolerated, but their mission among Muslims should be totally rejected. Al-Khiḍr Husayn bitterly asserted that their "greedy" ambitions exceeded the limits of converting non-Muslims and extended to influencing Muslim nations and peoples who were already "guided" by the "light" of the Qur'ān and Sunna. ${ }^{61}$ In order to combat their missionary work among Muslims, ceremonies were organized in Cairo to celebrate former Ahmadiyya members who wanted to denounce their affiliation to the movement publicly. ${ }^{62}$

At this stage, many of these scholars stopped expressing any appreciation of their work, including their missions in Europe. A certain Abū l-Makārim Muhammad 'Abd al-Salām al-Salīm, a lecturer of Arabic in Kurnool, India, requested that Muslim scholars in the East and North Africa, especially in al-Ḥaramayn (the Two Sacred Shrines), Shaykh al-Azhar, Shakīb Arslān, and al-Hilālī, issue a general clear-cut fatwā against the Ahmadiyya. ${ }^{63}$ The dispute then took another radical shift when many contributors to al-Fath penned heated articles against the Ahmadiyya and their doctrines and work. ${ }^{64}$

Shortly thereafter, in response, Shakīb Arslān agreed that specific doctrinal quotations in the Ahmadiyya books could eventually lead to unbelief and apostasy from Islam. Ghulam Ahmad's claimed prophecy would also harm the

61 Muhammad al-Khiḍr Ḥusayn, "Ṭā’ifa al-Qadyāniyya" [A Qadiyani sect], al-Fatḥ 7, no. 317 (3 Nov. 1932), 1-7 and al-Fath 7, no. 319 (17 Nov. 1932), 12-13.

62 In 1932, as founder and president of Jam'iyyat al-Hidāya al-Islāmiyya (Society of Islamic Guidance), al-Khiḍr Husayn welcomed a former head of the Ahmadiyya branch in Cairo and his secretary, who recanted their Ahmadiyya beliefs. This public celebration was attended by the Grand Shaykh of al-Azhar, the founder of the Muslim Brothers Hasan al-Bannā, and other prominent Muslims who congratulated the two men for their "bravery." See, al-Fath 8, no. 375 (14 Dec. 1932), 6-9 and al-Fath 8, no. 376 (21 Dec. 1933), 14-15. The Ahmadiyya center in Cairo was located in al-Khurfush district. It was mainly established to combat Christian missionary work in Cairo, but it was closed down by the police after conflicts with the Muslim inhabitants. Accused of public disorder, three Ahmadiyya members had to pay a fine of one pound each. See al-Fath 8, no. 376 (21 Dec. 1933), 3 and al-Fath 8, no. 377 (28 Dec. 1933), 3. See also, al-Fath, 9, no. 411 (7 Sept. 1934), 20-22; al-Fath 9, no. 415 (4 Oct. 1934), 2-3, 21-22; al-Fath 9, no. 416 (11 Oct. 1934), 18-19; al-Fath 9, no. 417 (18 Oct. 1934), 4.

63 As the highest religious position in Egypt, the shaykh al-Azhar was also required to draw the government's attention to the Ahmadiyya missionary center in Cairo which had to be closed down. Al-Fath 7, no. 324 (22 Dec. 1932), 1-4.

64 Al-Fath 7 , no. 325 (29 Dec. 1932), 5-6. 
Lahore branch if they did not recant it. Arslān, who visited their mosque in Berlin two times, had several discussions with the Ahmadi religious leader in Germany Mawlana Sadr-ud-Din (d. 1981), who repeatedly insisted to him that they merely considered Ghulam Ahmad a reformer. As Arslān had not studied any of their works in any depth, his judgment was mainly based on these meetings in Berlin and various oral reports about their doctrines. However, besides his deep respect for Mawlana Muhammed 'Alī and his writings on Islam, he still admired their zeal and their successful dissemination of Islam, which surpassed all other Muslim organizations in Europe. In Germany, they were successful in converting fifty elite Germans. In his correspondence with the Ahmadiyya Anjuman-i Isha'at-i Islam in Lahore, Arslān frequently advised them to believe in Ahmad as a reformer, and avoid any doctrines outside the boundaries of Islam. He never replied to the Qadiyani branch, who sought his support various times; he avoided any contact with them because of their belief in Ahmad as the Promised Messiah. ${ }^{65}$

Following Arslān, al-Hilālī quickly responded to the fatwā. His previous enthusiasm completely changed after he read some of Ghulam Ahmad's works. He bluntly considered him a "big charlatan...aiming at establishing supremacy, which is a kacba of all evil." ${ }^{\prime 6}$ Claiming to have a firsthand knowledge of their publications and work in India, al-Hilāli became one of the most prominent anti-Ahmadiyya writers in al-Fath. ${ }^{67}$ As for their activities in Europe, he completely changed his mind and wrote sarcastically: "Primary school children of

65 Shakīb Arslān, "al-Jawāb bi Sha’n al-Qadiyāniyya” [A response regarding the Qadiyaniyya], al-Fath 7 , no. 328 (19 Jan. 1933), 6-7.

66 Ibid., 7 .

67 See, for example, his reaction to their views on Islam and prophecy in "Voice of God," The Light (17 July 1933), 3-4: Taqī l-Dīn al-Hilāīi, "Sabb al-Qadiyāniyyīn li-l-Islām I \& II" [The offense of Qadiyanis to Islam I \& II ], al-Fath 8, no. 362 (15 Sept. 1933), 1-5 and al-Fatḥ 8, no. 363 (22 Sept. 1933), 13-16. Soon the anti-Ahmadiyya campaign was fueled in wider circles in Egypt and elsewhere in the Muslim world. See the articles by Shaykh Mușțafā Abū Yūsuf al-Ḥamāmī (d.c. 1949), an Azhari scholar and former imam of the well-known Zaynab Mosque in Cairo, al-Fath 7, no. 329 (26 Jan. 1933), 5-6, 13-14. About his works, see Mușțafā Abū Sayf al-Ḥamāmī, al-Nahḍa al-islāhiyya (Cairo, 1935); Ghawth al-ibād bibayna al-rashād (Cairo, 1950). See also the responses of Țaha Fayyāẹ al-Ānī, an Iraqi lawyer and journalist, al-Fatḥ 7, no. 332 (16 Feb. 1933), 10. Cf. Taqī l-Dīn al-Hilālī, "Bal hiya rābița Qadiyāniyya” [It is a Qadiyani association], al-Fatḥ 7, no. 340 (14 April 1933), 4-5; "al-Barāa min al-Qadiyāniyya" [Clearing one's name from the Qadiyaniyya], al-Fath 8, no. 372 (23 Nov. 1933), 3; al-Fath 8, no. 385 (1 March 1934), 12. See also the reaction by Taqi l-Dīn al-Nabhanī (1909-1977), later founder of Ḥizb al-Taḥrīr, Taqī l-Dīn al-Nabhanī, "al-Qadiyāniyya wa-l-falsafa al-hindiyya" [The Qadiyaniyya and Indian philosophy], 8, no. 372 (23 Nov. 1933), 14-15. 
the Christians in Europe would ridicule and laugh [at their doctrines]."68 Strangely enough, during these heated polemics, al-Hilāli used to quote some Ahmadiyya writings that supported his arguments in questions related to Islamic theology and prophecy in Islam. ${ }^{69}$

Amidst these fierce debates, al-Fath demanded the Ahmadiyya to issue a vehement denial on behalf of the Lahore branch, if they were serious in their claims of being close to Sunnī Islam. Muslims now became convinced that participating in their activities equaled "unbelief." ${ }^{\text {" In }}$ response to this antiAhmadiyya campaign in Egypt, the leaders of the general Ahmadiyya headquarters in Lahore set up a propaganda branch in Cairo in order to clarify their beliefs and the ways that they differed from the Qadiyani movement. But al-Fath remained unshaken in its conclusions: "The consequence of following the Qadiyani Ghulam will be the Hell-fire whether this was based on [the belief] in him as a 'prophet of the devil' or a 'modernizer' of the da'wa of the devil."71

European converts to Islam found themselves in the middle of these sectarian debates in national and transnational contexts. Some of them were active in both the Salafi and Ahmadiyya circles. For a while, their simultaneous activism in various Muslim circles downplayed the tone of bitter hostility on both sides. But eventually Salafi writers demanded that European converts deny any connection with the Ahmadiyya, if they were genuine believers in Islam and Sunnī Muslims. As we shall see, two prominent European figures became the central focus of the Salafi-Ahmadiyya polemic, the above-mentioned British convert Khalid Sheldrake (b. 1888) and the Austrian Baron Omar Rolf von Ehrenfels (1901-1980).

\section{Khalid Sheldrake: A European Sunnī Muslim}

If Headley had occupied a prominent place in al-Manār, Khalid Sheldrake was identified in al-Fath as a zealous new Muslim serving Islam in Europe. In the

68 al-Hilālī, "Sabb II," 13-16.

69 For example, he translated for the readers of al-Fath an article from The Muslim Revival, which was official magazine of the Ahmadiyya Anjuman-i Isha'at-i Islam Lahore (19321936), into Arabic about the "prophecies of world scriptures about the advent of the Prophet Muhammad." Al-Fath 8, no. 373 (30 Nov. 1933), 9-11. Cf. Muslim Revival (June 1933), 22-29.

$70 \quad$ Al-Fath 9, no. 418 (28 Oct. 1934), 8.

71 "Lahūrī Ablah" [A Lahori idiot], al-Fath 9, no. 429 (19 Jan. 1935), 4. They even approached 'Abd al- Hamīd Sa'ìd (d. 1940), the president of the Young Muslim Men's Association, to ask him to organize public events in order to address fellow Muslims about their beliefs in Mirza as a reformer, but not as a prophet. 
early years of his conversion, he became active in the Liverpool Muslim Institute (established in 1889 by the British convert Abdullah Quilliam (18561932)). He defended the Woking mission and regarded the Ahmadis as "part of the rich tapestry of the umma." ${ }^{2}$ By 1914 he claimed to be "Sheikh of the British Muslims," which annoyed the Woking Muslims and British converts, who asked him to leave; he was later readmitted. His congenial ties with the Qadiyanis after their khalifa's visit to London in 1924 irritated other Muslims. In response, Sheldrake clarified his preference for unity above division: "I accepted Islam, and schools of thought mean but little to me."73 In 1926, Sheldrake was again ejected from the Woking mission; but this time he convinced other converts, namely Omar Richardson, Osman Watkins, and Abdullah Day, to leave the Woking mission in order to establish the Western Islamic Association, a separate and non-sectarian Muslim organization. In Sheldrake's family home in South London (sometimes known as Peckham Mosque), they established a prayer room with an information center and distress and welfare fund. In addition, Sheldrake funded other activities, including a short-lived journal, the Minaret, and was able to make a few new converts. ${ }^{74}$

As noted, it was Sheldrake's question regarding the building of a mosque by non-Muslims in London in 1932 that triggered the controversy among Salafi writers about the Ahmadiyya missionary work in Europe. His role and activities in Europe were often portrayed in Salafì circles as those of a European Muslim who had no Ahmadiyya inclination. ${ }^{75}$ However, as late as 1931, Sheldrake wrote to the Lahoris in India that, despite being "unable to associate

72 Gilham, Loyal Enemies, 20o. See, for example, Khalid Sheldrake, "The Religion of Peace," Islamic Review and Muslim India 3 (1915), 25; "The Message to Mankind," Islamic Review 9, no. 1 (Jan. 1921), 21; "Our Duty To-day," Islamic Review 9, no. 2 (Feb. 1921), 71; "Islam and the Unity of Mankind," Islamic Review 9, no. 10 (Oct. 1921), 373; "Practical Experience of Islam," Islamic Review 9, no. 11 (Nov. 1921), 420; “More 'Massacres," Islamic Review 10, nos. 6-7 (June/July 1922), 267; "Muhammad and World Unity," Islamic Review 14, nos. 3-4 (March/ April 1926), 148.

73 As quoted in Gilham, Loyal Enemies, 201.

74 Ibid.

75 Taqī l-Dīn al-Hilālī, "Abdullah Daye: Akh Muslim yasqut min șufūf al-jihād [Abdullah Daye?: A Muslim brother fell down the rows of jihad]", al-Fath 7, no. 325 (29 Dec. 1932), 11. He translated an article by Sheldrake about the death of another British convert to Islam, Abdullah Daye, which the latter published in the Madras magazine Peace-Maker. Sheldrake eulogized him as his "right hand" in their common activities in the Association for British Muslims in England since his conversion in 1929. 
myself any longer with the Woking mission... I remain on the best of terms with the Ahmadiyya Anjyman Ishaat-i-Islam of Lahore." ${ }^{76}$

In November 1932, Sheldrake visited India in order to advance the role of European Muslims in Islamic unity by calling for a European Muslim congress devoted to the study of Muslim problems in Europe, to promote the Islamic $d a^{c} w a$, and to refute any allegations against Islam in Europe. Sheldrake related his conversion story to Arabic readers in order to prove his closeness to mainstream Islam. As he always hoped for Sunni-Shīi unity, Sheldrake observed the Friday prayer in the Great Mosque in Bombay, a Sunnī mosque; and later went to a Shīì mosque for the next prayers. ${ }^{77}$

Sheldrake took pride in European converts to Islam, including Napoleon Bonaparte's alleged conversion (it was said that he kept a copy of the Qur'ān in French with him during his battles and during his exile). Among other names were her Highness Khair-un-Nissa, the Dayang Muda of Sarwak, and her first cousin Conrad (Khalid) Simpson. ${ }^{78}$ Sheldrake received the Dayang Muda of Sarwak into Islam in February 1932. Her conversion created a sensation in Europe, and she later settled in Paris and had a "salon where many grande dames and Muslims meet." ${ }^{\prime 9}$ Interestingly, she embraced Islam while she was in an airplane, crossing the English Channel. As president of the British Muslim Society, Lord Headley regretted her "unfortunate" choice of an airplane for such a serious ceremony, and worried that she had hurt the feelings of many Muslims all over the world. He described her action "as a somewhat freakish departure from the good taste." 80 As for Simpson, he embraced Islam with the idea of helping Sheldrake in his mission, not because of any religious conviction, though he said that he rather liked the concept of brotherhood in Islam. ${ }^{81}$

At this time, Sheldrake became a self-proclaimed suburban king of Tartary and king of Islamistan in western China. He visited the Far East with Conrad Simpson in 1933 and together they received considerable press attention. For example, the English-language daily Singaporean newspaper The Straits Times

76 Gilham, Loyal Enemies, 201.

77 Taqī l-Dīn al-Hilālī, "Khalid Sheldrake fì l-Hind: ḥadīth lahu muhim 'an al-shu'ūn al-Islāmiyya" [Khalid Sheldrake in India: an important talk for him about Islamic issues], al-Fath 7, no. 326 (5 Jan. 1933), 6-7.

78 Al-Fath 7 , no. 327 (12 Jan. 1933). About Bonaparte's conversion, see, for example, Christian Cherfils, Bonaparte et l'Islam d'après les documents français et arabes, with a foreword by Abd El-Hakim (Paris, 1914).

79 "Head of seven million Muslims visits Singapore," Straits Times (26 June 1933).

8o English Moslem Peer Deplores Plane Conversion of Princess," New York Times (2o Feb. 1932), 17 .

81 "Head of seven million...," Straits Times. 
(26 June 1933) was impressed by Sheldrake as the "head of millions of Muslims," whose intention was to connect Muslims in Asia with their "brethren" in Europe. ${ }^{82}$

In India, other Muslim publications doubted Sheldrake's sincerity as a Muslim. The Muslim Review, a monthly review of the shī $\iota$ educational center Madrasatul Waizeen (College of Preachers) in Lucknow, accused Sheldrake of "trading" with religion merely in order to gain wealth through missionary activities in the West, unlike the Woking mosque's people, who were sincere in their dissemination of Islam in Europe. ${ }^{83}$ In a fierce response, the above-mentioned Taqī l-Dīn Hilāili defended Sheldrake's sincerity and efforts to convert many prominent and high-class Europeans and Americans to "true" Islam. Al-Hilālī retaliated, and accused the Ahmadiyya movement of explicitly deceiving Muslims by collecting money from India and elsewhere in the name of Islam in order to propagate their doctrines and to fulfill their own interests. ${ }^{84}$ In al-Hilāli's view, this press campaign against Sheldrake's visit to India was backed by the Ahmadiyya, who did not dare to criticize him in public. In response, al-Hilālī accused Kamal-ud-Din of accumulating a treasure after his arrival in London, and said that he used it only for his own comfort and for his heirs after him. Al-Hilālī, who had earlier highly praised the work of the Ahmadiyya in Europe, now changed his mind completely and said that the Ahmadis had exaggerated their work by enlisting the names of famous European converts, such as Sheldrake, who had in fact converted to Islam much earlier, even before the start of the Ahmadiyya's work in London. As for Lord Headley, al-Hilālī contested his financial integrity as well. In 1928, Headley succeeded in persuading the Nizam of Hyderabad to donate money for the establishment of a mosque in West Kensington, London; the site cost 28 , ooo pounds at the time, but the project was delayed for many years. He also distrusted the choice of the location of the mosque-beside night clubs and cinemas. He blamed Indian Muslims for being "foolish" in donating money to the Woking mosque in order to "propagate the fallacies made by the Prophet of Punjab [Ghulam Ahmad]."85

Sheldrake was accused by the Ahmadis of "flattering" other Muslims by essentially telling them what they wanted to hear. Al-Hilāli saw it as a false accusation because the Ahmadis envied his success among Indian Muslims

\footnotetext{
82 Ibid.

83 Taqī l-Dīn al-Hilālī, "al-Itijār bi-l-dīn" [Trading in religion], al-Fath 8, no. 371 (16 Nov. 1932), 9-12. See also other debates in the Ahmadiyya press during this visit. "Princess Sarawak on Islam," The Light (24 Jan. 1933), 2; "The European Muslims," The Light (8 Feb. 1933), 3; The Light (24 Jan. 1933), 9-10; The Light (24 Feb. 1933), 4.

84 Taqī l-Dīn al-Hilālī, "al-Itijār," 9-12.

85 Ibid., 10.
} 
after his speech in Calcutta. They intentionally organized the anniversary of Kamal-ud-Din's death on the same day as Sheldrake's lecture, just to compete with him. At this gathering, they distributed free pamphlets with photos of their "prophet" among Sheldrake's audience. Al-Hilālī was surprised that whereas The Light welcomed his trip to India, the Woking mosque in London was "fighting against him by all means." However, in al-Hilāli’s view, the Muslim world highly appreciated Sheldrake's work for the sake of Islam and poor fellow Muslims in Britain. ${ }^{86}$

Al-Hilāli accused the Ahmadis of "paradox and cunning" for "playing" with Sheldrake's name and that of other European converts; but Sheldrake had already uncovered this Ahmadiyya scheme by denying his conversion in their circles. Ahmadi attacks against Sheldrake were deemed as "testimony for him before all Muslims in the world that he seeks God's face only...." ${ }^{17}$ Al-Hilāli argued that the Ahmadi falsely accused him of making the trip to India to collect money in the name of the Muda of Sarawak. ${ }^{88}$ However, it should be noted that Muda of Sarawak received many letters from India regarding the tour of Sheldrake and Simpson in India; and for this reason she distanced herself from their statements on her behalf. 89

At this point, in order to unify all mainstream Muslims, Sheldrake was strongly urged to deny all connections with Ghulam Ahamd and his "absurd" mission as a reformer of Islam. ${ }^{90}$ In the Arab Muslim press in Egypt, Sheldrake distanced himself from the Ahmadi factions and defended his sincerity for Islam in Europe to such an extent that he lost his wealth and family for the sake of his new religion. ${ }^{91} \mathrm{Al}$-Fath boasted about Sheldrake's Muslim missionary activities in the Far East and southeast Asia and declared that he was "the greatest Muslim guide of the age." ${ }^{92}$ At this time, an Egyptian dignitary

\footnotetext{
86 Ibid.

87 Al-Fath 8, no. 371 (16 Nov. 1933), 12.

88 Ibid., 12.

89 The Light (June 1933), 11.

9o An example of that was his support to the Egyptian nationalist Mușțafā Kamīl (1874-1908) during the well-known Dinshwai campaign led by the latter in England in 19o6. Al-Fath 7, no. 327 (12 Jan. 1933), $1-2$.

91 Khalid Sheldrake, "al-Duktūr Khalid Sheldrake yataḥaddath ‘an tārīkh 'alāqatih bi-l-Islām wa yu lin barāatahu min al-Aḥmadiyya wa-l-Qadyāniyya awalan wa-ākhiran” [Dr. Khalid Sheldrake speaks about the history of his relationship to Islam and clears his name from any connection with the Ahmadiyya and Qadiyaniyya], al-Fath 8, no. 383 (15 Feb. 1934), $6-7$.

92 "Al-Duktūr Khalid Sheldrake wa-rihalātuh fì l-sharq" [Dr. Khalid Sheldrake and his trips in the East], al-Fath 8, no. 385 (1 March 1934), 7.
} 
appealed to Shaykh al-Azhar to donate money to the Ahmadiyya movement to support their efforts to spread Islam in England. But the editor of al-Fath was disappointed, and campaigned instead for financial support for Sheldrake's activities; the editor claimed that he served the "genuine" Islam in Europe. ${ }^{93}$ To his Arab readers, Sheldrake did not deny that he maintained good ties with Mawlana Muhammed 'Alī, but this did not mean that he had any direct association with the Ahmadiyya. He said that although the Ahmadis intended to destroy his reputation by linking his name to their mission in Europe, his efforts were still appreciated by many Muslim leaders in Europe, such the Agha Khan, the above-mentioned Hāfiz Wahba, and the Egyptian consul to the United States. He also claimed to be a defender of the Palestinian cause, and sent money for Palestine, and supported the cause of needy Muslim seamen and their families in Britain. ${ }^{94}$ After his trip to the Orient, Sheldrake was keen on presenting himself as a defender of panIslamic endeavors. ${ }^{95}$

\section{Omar Rolf Baron von Ehrenfels: A Controversial Convert}

While Sheldrake was closely engaged with Salafì groups in Egypt, the abovementioned Baron von Ehrenfels became a controversial convert in these circles because of his evident connection with the Ahmadiyya in Berlin. ${ }^{96}$ Initially, von Ehrenfels was praised by the Ahmadiyya for his founding role in the establishment of the Islamische Kulturbund (Association of Muslim Culture) in

93

94 Khalid Sheldrake, "Li-mādha yaḥmilu 'alayya al-Aḥmadiyyūn?” [Why are the Ahmadis against me?], al-Fath 9, no. 421 (15 Nov. 1934), 22-23.

Khalid Sheldrake, "Mustaqbal al-Islām" [The future of Islam], al-Fatḥ 9, no. 434 (21 Feb. 1935), 12-13. Khalid Sheldrake, "al-Yapān wa-l-Islām al-ḥaqq" [Japan and genuine Islam], al-Fath 9, no. 439 (5 April 1935), 18-19.

See some of Baron Omar Rolf von Ehrenfels' works: "Islam and the Present Generation in Europe," Islamic Review 20, no. 11 (Nov. 1932), 383; "Muslim Women in Present-Day Europe," Islamic Culture 24, no. 10 (July 1936), 471; "The Pre-Aryan Cultures of India and the Ethnological Background of Islam," Islamic Culture 13, no. 2 (April 1939), 176; "Ethnology and Islamic Sciences," Islamic Culture 14, no. 4 (Oct. 1940), 434; Mother-Right in India (Hyderabad: Government Central Press, 1941); "A Scheme for Equitable Distribution of Zakat," Islamic Review 34 (1946), 407; “The 'How?' and 'Why?' of Conversion to Islam,” Islamic Review 49, no. 6 (June 1961), 23; "Islam und Wissenschaft," Kairos: Zeitschrift für Religionswissenschaft und Theologie 5 (1963), 114; Das Kulturproblem der Entwicklungshilfe im Südasiatischen Raum (Heidelberg: Universität Heidelberg. Südasien-Institut, 1966). 
Vienna. ${ }^{97}$ However, the Ahmadis were criticized by Khalid Simpson for having given little credit to the Egyptian medical doctor Zākì 'Alī, an associate of Arslān, and for his co-founding role with von Ehrenfels in the Islamische Kulturbund in Austria. Moreover, it was Zākī 'Alī who also tried in collaboration with Sheldrake to organize the Muslims of central Europe. ${ }^{98}$ In response, the Ahmadis apologized for this unintentional mistake and stressed that other Muslims working in Europe, including Sheldrake, should be given due credit. They warned other European Muslims against "imbibing the virus which has sapped all validity out of Eastern Muslims. Mr. Simpson's letter plainly shows that some so-called 'friends' of his have been trying to inject the same poison into him." ${ }^{99}$ Therefore, sectarianism should be denounced by European Muslims in order to proceed with the "Islamization" of Europe. ${ }^{100}$

In 1932-1933, von Ehrenfels traveled to India accompanied by Muhammad S. Abdullah, the imam of the Ahmadiyya Berlin mosque. As in the press coverage about Headley's visit to Cairo almost ten years before, von Ehrenfels' arrival in Lahore was described by the Ahmadi magazine The Light: "as the Frontier Mail slided in, the platform resounded with shouts of Allah-o-Akbar. On alighting from the train, the Baron and the Imam were profusely garlanded and it was stilt great difficulty that a way could be forced out of the huge crowd to the car, bedecked with flowers."101 Taqī l-Dīn al-Hilālī translated The Light's report about von Ehrenfels' visit, the welcoming of the Ahmadiyya to his project to translate the Quraan into German, and the plans to start a Muslim mission and build a mosque in Vienna. Al-Hilāī saw the Baron's choice of India to increase his knowledge of the Islamic sciences as an unfortunate one. He chose India because Qadiyani (he did not use the Lahori) Muslims were not welcomed anymore in Egypt, the Hijaz, Yemen or Syria. The Ahmadis allegedly kept von Ehrenfels away from the centers of "Muhammadan Islam" for fear that their "fallacies" would be unearthed.102

97 "Iḥtifāl al-Muslimīn fī l-Nimsā bi-ta’sīs rābițat al-thaqāfa al-Islāmiyya" [Celebration of Muslims in Austria to the inauguration of the Association of Muslim Culture], al-Fath 7, no. 324 (22 Dec. 1932), 15. It enthusiastically announced its inaugural festivity and postal address in Austria without giving any reference to its Ahmadiyya character.

98 "The European Muslims," The Light (8 Feb. 1933), 3.

99 Ibid., 4.

100 Ibid.

101 "The Anjuman's Anniversary," The Light (Jan. 1933), 1.

102 Taqī l-Dīn al-Hilālī, "al-Baron Omar Rolf al-Nimsāwī aslama islāman qadiyāniyyan" [The Austrian Baron Omar holds a Qadiyani Islam], al-Fath 7, no. 337 (24 March 1933), 14. To combat the Ahmadiyya Light magazine, he suggested that the English supplement of 
Baron von Ehrenfels publicly announced that he never denied Zākì 'Alī's support as a secretary of Kulturbund in Vienna; and said that he had he always had good "brotherly" relations with him. ${ }^{103}$ Meanwhile, on behalf of the Kulturbund, a certain Muhammad Saljaq al-Busnawī, a member of the Kulturbund's board, strongly rejected the "rumors" ascribed to the Baron that he had converted to Islam according to the Ahmadiyya doctrines; and that their society was connected in any way to the Ahmadiyya movement in Europe. Zākī 'Alī's main objective was to establish an Islamic center in the heart of Europe. His choice of the Baron as its president was because of the latter's sincerity and fame as a European writer. It was a condition of the board that the Baron should not attach himself to any Muslim organization that was at odds with the mainstream consensus in the Muslim world. The Kulturbund had several connections with Muslim organizations, including the Ahmadis. This was, therefore, the reason he was invited to deliver lectures in India in many Muslim circles, including the Ahmadiyya in Lahore. The Kulturbund's board warned von Ehrenfels against expressing any direct affiliation with the Ahmadiyya, or, they said they would be compelled to replace him in that position. They also sent a declaration to the Indian press regarding this issue. ${ }^{104}$ Al-Khațīb was relieved by this news and appreciated the Kulturbund's publicity in India. "If my father were connected to the Qadiyanis," he wrote, "I would launch a 'war' against him and would warn all Muslims against him."105

\section{Sense of Competition and Climax}

In this context, and because they perceived a sense of competition with the Ahmadiyya missionary work in Europe, al-Fath became keen on countering their missions by reporting the "success" of non-Ahmadiyya Muslim missions in Europe. ${ }^{106}$ They strongly urged Muslims to form a front of European and American converts who could stand up to the spread of Catholic and Protestant allegations against Islam. The historical changes in Europe of that time

al-Azhar mouthpiece, Nūr al-Islām, should include a chapter entitled: "The Light of Islam" in which anti-Islamic ideas could be refuted.

103 The Light (24 Feb. 1933), 4.

104 "Bar’a min al-Qadiyāniyya" [Innocent of being a Qadiyani], al-Fatḥ 7, no. 340 (24 April 1933), 14.

105 Ibid.

106 Ḥasan Anwar, "al-Daćwa ilā l-islām fī Ūrubā" [Islamic mission in Europe], al-Fatḥ 8, no. 381 (1 Feb. 1934), 6-7. 
indicated that it was a suitable time to launch such solid Islamic missions in Europe. After World War I, the European and American public had changed; and it was high time for Muslim missionaries to clarify the "values of Islam" in Europe. In the past, western political parties and leaders had nourished the western Christian public opinion against Islam in order to get rid of Muslims on the European continent. This spirit thoroughly dominated in Europe before the war, and negatively effected Muslim minorities in these states, especially in Hungary and Poland. Therefore, al-Khațîb saw it as a pressing issue for Muslims to strengthen their presence in Europe by establishing religious, economic, and social relations with Europeans. He especially lamented the "weakness" and "ignorance" of Muslims in eastern Europe, and hoped that the European Muslim Congress (1935) in Geneva would sustain them in their religious affairs. ${ }^{107}$

Previous conversions in the Woking mosque were again brought into question. These accounts were confused. A certain Ahmad al-Sharîf, an Egyptian living in Berlin, cast doubt on the authenticity of Lord Headley's conversion to the "true" Islam. ${ }^{108}$ Despite this clear anti-Ahmadiyya line of thought, the conversions of new European Muslims were confused and inconsistently recalled in these Salafì circles. For example, Lord Headley's role in the conversion of other elite British people to Islam was eulogized. An Arabic summary of the introduction of Lady Evelyn Cobbold's book, Pilgrimage to Mecca, ${ }^{109}$ which was about her conversion, was discussed in al-Fath at length without referring to her active role in the Woking mosque in London. ${ }^{110}$

The disputes about the Ahmadiyya's position in Europe resonated among Egyptian readers. Some Egyptians were already in contact with the Woking mosque. A certain Mahmūd Ḥamdī 'Alī, president of the association of al-Muslim al-Ämil (the Active Muslim, which was affiliated with the Muslim Brothers) in Cairo, was a reader of Ahmadiyya (such as The Islamic Review) and Salafi journals. Being confused about their religious work in Europe, he contacted the Woking mosque in London (August 1934) with an inquiry about the prevailing "rumor" in

\footnotetext{
107 Al-Fath 8, no. 399 (4June 1934), 1-3.

108 Aḥmad al-Sharīf, "al-Lāhūriyyūn wa-Britānia" [The Lahoris in Britain], al-Fath 9, no. 423 (29 Nov. 1934), 20-22. See also al-Fath 9, no. 426 (20 Dec. 1934), 11.

109 Al-Fath 9, no. 429 (18 Jan. 1935), 11. See also, William Facey, "Mayfair to Makkah," Saudi Aramco World 59, no. 5 (2008): 18-23; available online: http://www.saudiaramcoworld .com/issue/200805/mayfair.to.makkah.htm (accessed 20 March 2014).

110 Cobbold's name was also enlisted in the Ahmadiyya volume of conversion stories of Europeans. Khwaja Nazir Ahmad Cobbold, Charms of Islam: A Collection of Writings of Some of the Eminent Scholars (Woking: Woking Muslim Mission \& Literary Trust, 1935), $45^{-47 .}$
} 
Egypt that concerned their propagation of the prophecy of Ghulam Ahmad in Europe."11 The Islamic Review published 'Ali's letter after a few months and stressed that their mosque was neither a Qadiyani nor an Ahmadi movement. They believed in the Prophet Muhammad as the seal of prophecy, and belonged to the Hanafi school of thought. Any claimant of prophecy after him was considered beyond the pale of Islam. ${ }^{112}$ In al-Fath, 'Alī noted that his message was effective because the magazine changed its Arabic caption from "naḥmaduh wa nuṣalli 'ala rasūlih al-karīm" (we thank Him [God] and our prayers are upon his generous prophet) to "naḥmaduh wa nuṣallì wa nuṣallim 'ala rasülih Muhammad khațam al-nabiyyin" (we thank Him and our prayers and greetings are upon his messenger Muhammad, the seal of prophecy). ${ }^{113} \mathrm{Al}$-Fath tried to convince its reader that the Lahore branch was rather a "chameleon," that changed its "colors."14

Those in the Salafì circles were not clear about the nature of the Ahmadiyya work in Europe. The same Mahmmūd Ḥamdī 'Alī published an Arabic translation of the 1934 Eid al-Adha sermon delivered in the Woking mosque by the above-mentioned envoy extraordinary of the King of Hijaz in London Shaykh Hāfiz Wahba. This article was placed in al-Fath a few pages after a thorny antiAhmadiyya article written as part of a series by the former president and secretary of the Ahmadiyya branch in Cairo. ${ }^{115}$ The editor of al-Fath, a great sympathizer of the King of Hijaz, probably forgot that Haafiz Wahba was a regular visitor to the Woking mosque. It should be noted that Wahba was close to the imam of the mosque and delivered the sermons there several times. ${ }^{116}$

Nevertheless, in the mid 1930s these inconsistent attitudes coincided with the peak of the anti-Ahmadiyya campaign in the Muslim press worldwide. Still, it was sometimes presumed that the Woking mosque was not directly affiliated with the Ahmadiyya because of their defense of Sunnī Islam and the reception of Muslim dignitaries visiting Britain. On 30 June 1935, Prince Sa ūd, eldest brother of King 'Abd al-'Azīz Āl Sa'ūd, was cordially received at the Woking mosque during his visit to London. ${ }^{117}$

\footnotetext{
111 See Islamic Review (March 1935), 108.

112 Ibid., 81.

113 Islamic Review (Sept. 1934), 1.

114 al-Fath 9, no. 445 (16 May 1935), 17-18.

115 See al-Fath 10, no. $45^{6}$ (2 Aug. 1935), 13-15; cf. 18-19.

116 See, for example, Islamic Review (July 1934), 221-223. See Wahba's photo with his signature in Islamic Review (March-April 1931).

117 Islamic Review (Aug. 1935).
} 
Meanwhile, al-Fath announced, as surprising news, that the Woking mosque had been finally and conclusively "unmasked" as an Ahmadi religious institution after years of vacillating. Although many Muslims, both in the Muslim world and in Europe, were still confused about its nature, the affiliation of the Woking mosque with the Ahmadiyya became evident after the Ahmadiyya representative in Cairo distributed Mawlana Muhammad 'Alī's book, al-Bayān fìl-rujü' iläl-Qurāan, in which the author openly stated that the Woking mosque in London and the Muslim Mission in Berlin were associated to the Lahore Ahmadiyya. ${ }^{118}$

By this time, Shaykh Muḥammad 'Abd al-Salām Salīm al-Hazarwī (Hazarvi) (1898-1947), ${ }^{119}$ a well-known teacher of Islamic sciences in Mysore (India), was keen on informing his Arab "brethren" through al-Fath about the real nature of the Woking mosque and their "hypocrisy." As one of the fiercest opponents of the Ahmadiyya in the region, al-Hazarwi urged people to boycott the Ahmadiyya altogether. In May 1935, Abdul-Majid, the imam of Woking, and Khwaja Abdul-Ghani, secretary of the mosque, visited al-Hazarwī in order to convince him that their mosques and activities in Europe were neither associated to the Qadiyanis, nor to the Lahore line of belief, rather, they stated, they were followers of Ahl al-Sunna wa-l-Jama'a. During this meeting, al-Hazarwi requested that they sign a paper on which they clearly state that Ghulam Ahmad was an unbeliever ( $k \bar{a}$ fir ) because of his claim of prophecy, but they refused. This was, for al-Hazarwī and al-Fath, definitive proof of their separation from Islam. ${ }^{120}$

The above-mentioned Egyptian Mạ̣mūd Hamdī 'Alī gently blamed al-Khațib for persisting in this stance regarding the Muslims of the Woking mosque, who did not explicitly consider Mirza Ghulam Ahmad as a prophet. But al-Khațîb remained adamant in his position. For him, the Ahmadiyya Lahore missionaries, including Mawlana Muhammad 'Alī and Kamal-ud-Din, were clandestinely concealing their real nature behind their claim that the Mirza was a reformer, in order to achieve their goals, which ultimately served British colonial interests. ${ }^{121}$ In the view of al-Fath, another proof of their hatred of Islam was the joy expressed by a Qadiyani paper in India at the death of

\footnotetext{
118 al-Fath, 10, no. 475 (12 Dec. 1935), 6.

119 About him, see online at: http://www.almoajam.org/poet_details.php?id=3920 (accessed 20 March 2014).

120 al-Fath 10, no. 454 (18 July 1935), 8-10.

121 al-Fath 10, no. 456 (2 Aug. 1935), 8-10; see also, al-Fath 10, no. 461 (5 Sept. 1935), 14-15; al-Fath 10, no. 464 (26 Sept. 1935), $16-17$.
} 
Rashīd Riḍā; it stated that his demise was the "perishing of the first and the strongest adversary of the Promised Messiah...in the Muslim world."122

European converts started to demand that the Woking leadership disassociate themselves from the Ahmadiyya. Led by Sheldrake, a group of British converts, including Sir Omar Hubert C. Rhys Stewart-Rankin (1899-1988) and Sir Charles Edward Abdullah Watkin Hamilton (1876-1939), disclaimed any relationship with Lord Headley, and regretted their earlier friendship with the Ahmadiyya altogether. To Sheldrake, the Ahmadis were "tricky people" who caused him "pain."123 At this point, some British converts severed their ties to the Woking mosque. After Headley's death in 1935, Omar Stewart-Rankin succeeded him as president of the British Muslim Society. A month later, he resigned after a meeting with the Woking members during which he put forward a resolution that the mosque should not have any connection with the Ahmadis in India. When his resolution was defeated, Stewart-Rankin and other members walked away. He decided therefore to form a new "orthodox and non-sectarian" Muslim society. ${ }^{124}$ Stewart-Rankin's move was seen by some other converts as a "non-sensical split...through his impulsiveness." ${ }^{25}$ Mubarak Fuelling, a Qadiyani British convert, even criticized this split by arguing that most British Muslims were "led like sheep in all matters that affected Islam by any man from the East who had a beard or spoke Arabic."126

A few days later, al-Khatịb received the news of Stewart-Rankin's split from the Ahmadiyya in London with great joy. For him, it was now the right time to "purify" the Islamic da'wa in Britain from the "filth" of the Ahmadiyya. He boasted that it was his magazine that raised its "gentle voice" against their work in Britain from the start. But his "good intentions" regarding the Woking mosque and The Islamic Review in the beginning were spoiled by mosque's refusal to clearly distance itself from Ghulam Ahmad. He saw Stewart-Rankin's resignation as a result of anti-Ahmadiyya voices in the Muslim world. ${ }^{127}$

Similarly, at the invitation of the Islamische Gemeinde in Berlin, a group of more than fifty Muslims living in Berlin gathered and issued a declaration to the Muslim world to condemn and boycott the Ahmadiyya activities in Europe. They denounced their work as "charlatanry" in the name of Islam. The list included Arab, Indian, and European names, such as the converts Walter

\footnotetext{
122 al-Fath 10, no. 470 (7 Nov. 1935), 13.

123 Sheldrake, "Li-mādha," 14-15. See al-Fath 9, no. 417 (18 Oct. 1934), 4.

124 "British Muslims' Leader Resigns," Times (12 Dec. 1935).

125 See Gilham, Loyal Enemies, 204.

126 Ibid.

127 al-Fatḥ 10, no. 476 (19 Dec. 1935), 6-7.
} 


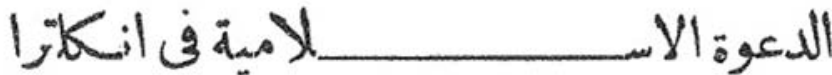

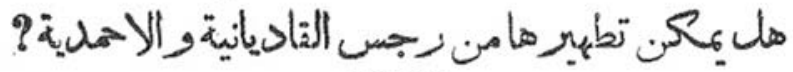 \\ eององ}

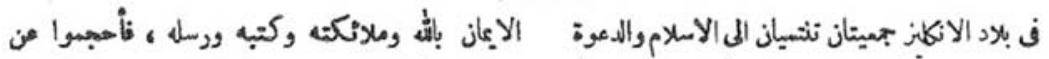

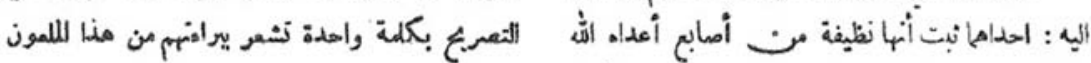

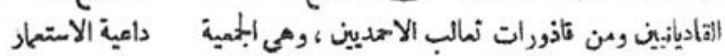

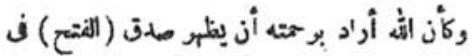

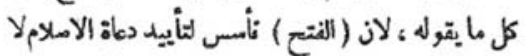

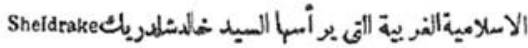

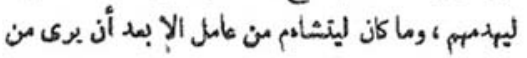

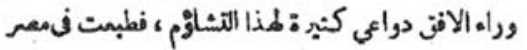

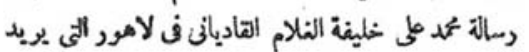

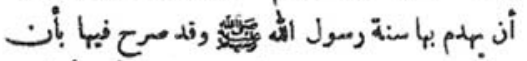

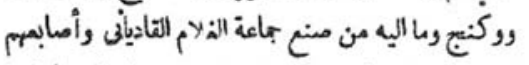

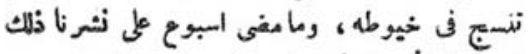

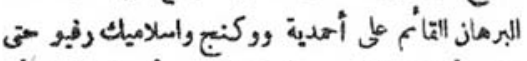

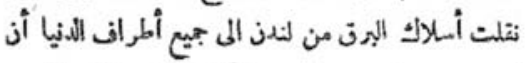

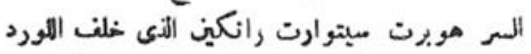

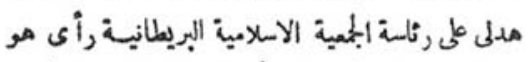
وبعض اخوانه المخلصبن أن الصبغة القاديانية لمعيته

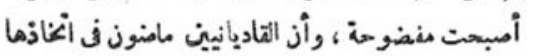

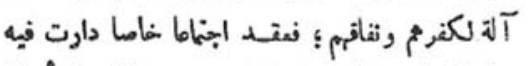

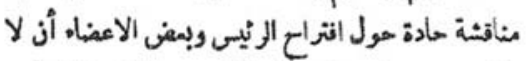

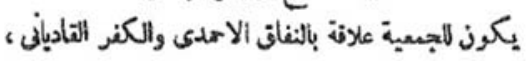

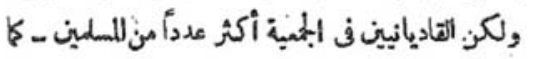

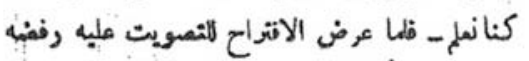

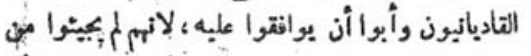

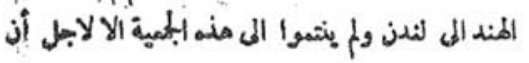

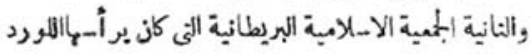

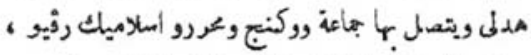

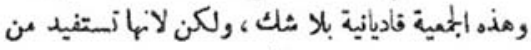

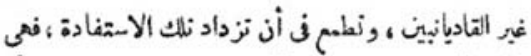

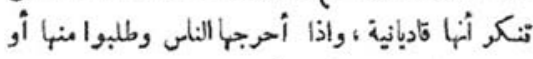

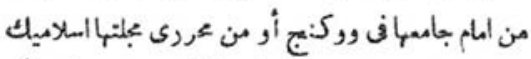

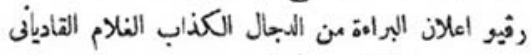

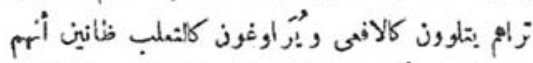

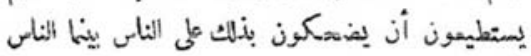
يفهمن جميع حركاتهم

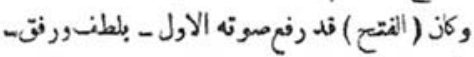

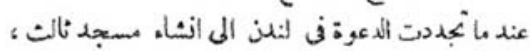

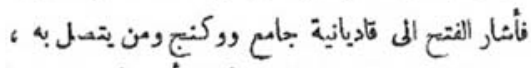

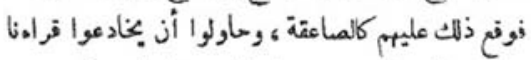

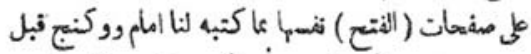

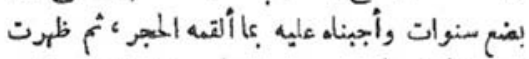

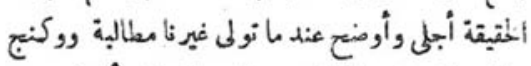
واسلاميك رفيو بالبراءة من الفلام الدجال ، أو أو التصريج

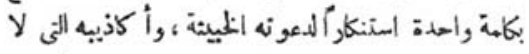

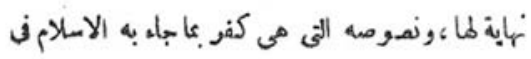




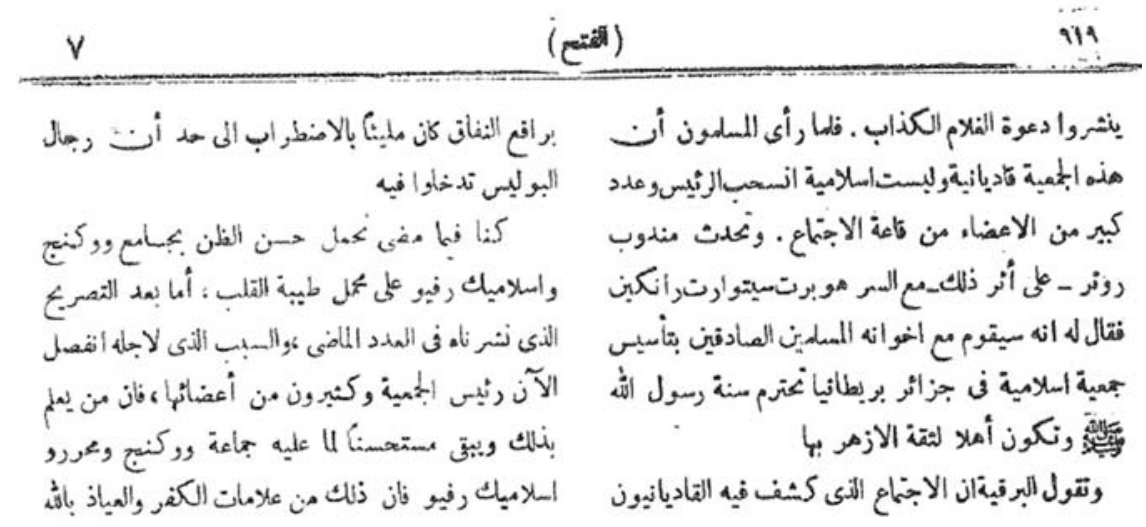

FIGURE $3.4 \quad$ (continued)

Mohammed Hasan Hoffmann, Chalid-Albert Seiler-Chan, Faruq Fischer, and S. Umar W.A. Schubert, ${ }^{128}$ who later supported the establishment of another Muslim congregation in Berlin.

\section{Conclusion}

As we have seen, the individuals analyzed in this chapter followed specific paths that elucidate, in different ways, the many worlds in which they lived. In particular, the history of European converts to Islam highlights aspects of the shifting patterns of interaction not only between Muslims and European society, but also with the global Muslim community in the interwar period. It is clear that they, as European actors, crossed boundaries in the transcultural history of the period; this was a result of their active role as new Muslims connecting the East and West. Their role was also a function of the intra-Muslim religious debates between the Salafiyya and Ahmadiyya as conflicting branches of Islam of that time.

As a matter of fact, the multifold and deeply-rooted conflicts between the Salafiyya and Ahmadiyya were uncompromising. However, we have observed that the presence of European converts as new and engaging figures unconsciously created a certain commonality between these disagreeing Muslim branches through their entwining role in Europe. They all had one goal in common, namely the relevance of Islam on European soil. The chapter has also tried to demonstrate the interconnected history of the Salafiyya, Ahmadiyya,

128 al-Fath 10, no. 478 (2 Jan. 1936), 17. My gratitude to Gerdien Jonker for her help in identifying these figures. 
and European converts in a common past that was not only characterized by enduring conflict, but also by the exchange of ideas. In other words, these conflicts were not always primarily translated into complete boycott, but knew many blurry zones. This can be seen quite clearly in the unprecedented Egyptian welcome of Lord Headley despite his Ahmadiyya affiliation. As for the case of the Salafi-leaning journal al-Fath, despite its editor's vehement dislike of the Ahmadiyya, he allowed many writers to express positive remarks about the Ahmadiyya's role in Europe.

Salafî responses to the Ahmadiyya in Europe were ambivalent. Initially, some Salafi writers recognized the significance of the symbolic and organizational centrality of the Woking mosque in the interwar period and its importance for the presence of Islam in Europe in general. Nevertheless, Addison's remarks in 1929 on the reluctance of the Lahore group to admit any connection with the Ahmadiyya movement, especially their eagerness to modify their message according to the fashion of the hour, correctly corresponds with the hesitant appreciation of the reformist figures discussed in the chapter. It may be no surprise therefore that Riḍa did not consider Khwaja Kamal-ud-Din after the latter's death as a true follower of the Ahmadiyya.

The change of the Salafiyya movement to a more "populist" turn radically affected the image of the Ahmadiyya in the Muslim world. Al-Fath, which was, initially, somewhat positive about the Ahmadiyya's missionary work in Europe, boldly demanded that the Lahore group disavow their connection with Mirza Ghulam Ahmad altogether. In 1940, Hasan al-Banna, the founder of the Muslim Brothers, continued the anti-Ahmadiyya campaign when he became the editor of al-Manār at the request of Ridâ̄'s family. ${ }^{129}$

Among European converts, Lord Headley and Khalid Sheldrake occupied prominent places in Salafĩ circles. Headley remained closely connected to the Woking mosque until his death in 1935, while Sheldrake maintained close contacts with Salafĩ circles in the East. Despite his several writings in Ahmadi publications, he ultimately created a swift anti-Ahmadiyya backlash in the Muslim Salafì press. In the late 1930s, Sheldrake disappeared from the scene and became a business representative in Turkey and a part-time employee of the British Council in Ankara. He died in London in 1947, three years after his return to Britain. Despite his role in the formative making of British Islam, his death was ignored in the British and mainstream Muslim press. ${ }^{130}$ David/Dawud Cowan (1915-2003), a British convert and assistant imam in the Woking mosque, recalled to Gilham many decades later that "Sheldrake was considered a bit of

129 al-Manār 35, no. 7 (April 1940), 443.

130 Gilham, Loyal Enemies, 237. 
a charlatan...Various people said Sheldrake talked about Islam for the profit of British secret service."131 Although one must take such later testimonies with a grain of salt, they reflect at least the images made among these converts amid such disputes.

Interwar European converts still occupy a special place in the writings of some prominent contemporary Muslim scholars in the generation after World War II. For example, the well-known Grand Shaykh of al-Azhar (1910-1978), 'Abd al-Halīm Mạmmūd, was an al-Azhar student completing post-graduate degrees in Europe in the 1930s. In Paris, he met with Khalid Sheldrake in the literary salon of Dayang Muda of Sarwak, where he was impressed by this intellectual sphere that gathered European converts to Islam in the French capital. ${ }^{132}$ This experience led this traditional Azhari scholar to write his famous book on the relationship between Europe and Islam. Mahmūd cited Lord Headley, along with the French convert to Islam Étienne Dinet (18611929), as an exemplary European Muslim who rendered a great service to Islam in Europe; Mahmūd avoided any reference to Headley's Ahmadiyya background in the interwar period. ${ }^{133}$

\section{Bibliography}

Abou Sheishaa, Mohamed Ali Mohamed. "A Study of the Fatwā by Rashid Ridā on the Translation of the Qur'an." Journal of the Society for Qur'änic Studies 1, no. 1 (Oct. 2001). Online: http://www.Qur'ān.org.uk/out.php?LinkID=61 (accessed 24 March 2014).

Addison, James Thayer. "The Ahmadiya Movement and Its Western Propaganda." Harvard Theological Review 22, no. 1 (January 1929).

Ahmad, Mirza Ghulam. al-Hudāwa-l-tabșira limanyarā.Tilford, Surrey, UK:al-Shirkatul al-Islāmiyya Limited, 2011 (repr. 1902). Online: http://www.islamahmadiyya. net/books2.asp?book_key=67\&magazine $=0$ (accessed 20 March 2014).

- Ijäz al-masih. Tilford, Surrey, uk: al-Shirkat al-Islamiyya Limited, 2011 (repr. 1901). http://www.islamahmadiyya.net/pdf/ijaz_maseeh_full.pdf.

131 Ibid., 289. Cowan was later employed in the Middle East section of the ministry of information, Gilham, Loyal Enemies, 216.

132 'Abd al-Ḥalīm Mạ̣mūd, al-Hamdu li-Llāh hadhihi hayātī (Cairo: Dār al-Macārif, 1985), 121-122; for more about him, see Hatsuki Aishima, "'Abd Al-Halim Mahmud (1910-78) and his Audiences: Mass Media and the Transformation of Islamic Learning in Contemporary Egypt" (PhD diss., University of Oxford, 2011).

133 'Abd al-Ḥalīm Maḥmūd, Uruba wa-l-Islām (Cairo: Dār al-Ma'ārif, 1991), 67-72. 
Aishima, Hatsuki. "Abd al-Halim Mahmud (1910-78) and his Audiences: Mass Media and the Transformation of Islamic Learning in Contemporary Egypt." PhD dissertation, University of Oxford, 2011.

al-Ānī, Ṭāha Fayyāḍ. al-Fatḥ 7, no. 332 (16 Feb. 1933).

Ansari, K. Humayun. "The Woking Mosque: A Case Study of Muslim Engagement with British Society since 1889." Immigrants \& Minorities 21, no. 3 (2002).

Anwar, Ḥasan. "al-Da'wa ilā l-islām fī Ūrubā" [Islamic mission in Europe]. al-Fath 8, no. 381 (1 Feb. 1934), $6-7$.

Arslān, 'Ādil. "al-Dacwā ilā l-Islām fì l-gharb” [Calling for Islam in the west]. al-Fath 7, no. 308 (2 Sept. 1932).

Arslān, Shakīb. "al-Jawāb bi-sha'n al-Qadiyāniyya" [A response regarding the Qadiyaniyya]. al-Fath 7, no. 328 (19 Jan. 1933), 6-7.

Cherfils, Christian. Bonaparte et l'Islam d'après les documents français et arabes, with a foreword by Abd El-Hakim. Paris, 1914.

Clayer, Nathalie and Eric Germain, eds. Islam in Interwar Europe. London: Hurst, 2008. Cobbold, Khwaja Nazir Ahmad. Charms of Islam: A Collection of Writings of Some of the Eminent Scholars. Woking: Woking Muslim Mission \& Literary Trust, 1935.

von Ehrenfels, Baron Omar Rolf. "Ethnology and Islamic Sciences." Islamic Culture 14, no. 4 (Oct. 1940).

_ . "The 'How?' and 'Why?' of Conversion to Islam." Islamic Review 49, no. 6 (June 1961).

—. "Islam and the Present Generation in Europe." Islamic Review, 20, no. 11 (Nov. 1932).

_. "Islam und Wissenschaft." Kairos: Zeitschrift für Religionswissenschaft und Theologie 5 (1963): 114 .

—. Das Kulturproblem der Entwicklungshilfe im Südasiatischen Raum. Heidelberg: Universität Heidelberg. Südasien-Institut, 1966.

-. Mother-Right in India. Hyderabad: Government Central Press, 1941.

—. "Muslim Women in Present-Day Europe." Islamic Culture 24, no. 10 (July 1936). "The Pre-Aryan Cultures of India and the Ethnological Background of Islam." Islamic Culture 13, no. 2 (April 1939).

"A Scheme for Equitable Distribution of Zakat." Islamic Review 34 (1946), 407.

Facey, William. "Mayfair to Makkah." Saudi Aramco World 59, no. 5 (2008): 18-23. Online: http://www.saudiaramcoworld.com/issue/200805/mayfair.to.makkah.htm (accessed 20 March 2014).

Germain, Eric. "The First Muslim Mission on a European Scale: Ahmadi-Lahori Networks in the Interwar Period." In Islam in Inter-War Europe, edited by Nathalie Clayer and Eric Germain. London: C. Hurst \& Co., 2008.

Ghazar, Amal N. "Power, Arabism and Islam in the Writings of Muhib ad-Din aI-Khatib in al-Fath." Past Imperfect 6 (1997): 133-150. 
Gilham, Jamie. Loyal Enemies: British Converts to Islam 1850-1950. London: Hurst, 2014.

al-Ḥamāmī, Mușțafā Abū Sayf. Ghawth al-ibād bi-bayna al-rashād. Cairo, $195^{\circ}$. al-Nahda al-islāhiyya. Cairo, 1935.

Hanson, H. "Jihad and the Ahmadiyya Muslim Community: Nonviolent Efforts to Promote Islam in the Contemporary World." Nova Religio 11, no. 2 (2007): 77-93.

Headley, Rowland George Allanson. "Why I became a Mohammedan." Observer (23 November 1913).

al-Hilālī, Muḥammad Taqī l-Dīn. "Abdullāh Daye: Akh Muslim yasqut min ṣufūf al-jihād [Abdullah Daye?: A Muslim brother fell down the rows of jihad]". al-Fath 7 , no. 325 (29 Dec. 1932a).

—. "Bal hiya rābița Qadiyāniyya" [It is a Qadiyani association], al-Fath 7, no. 340 (14 April 1933a).

. "al-Barā'a min al-Qadiyāniyya" [Clearing one's name from the Qadiyaniyya]. al-Fatḥ 8, no. 372 (23 Nov. 1933b).

- "al-Baron Omar Rolf al-Nimsāwi aslma islāman qadiyāniyyan" [The Austrian Baron Omar holds a Qadiyani Islam]. al-Fatḥ 7, no. 337 (24 March 1933c), 14.

- "Fì tarjamat al-Qur'ān ayḍan" [Regarding the translation of the Qurān, too]. al-Fath 6, no. 293 (6 April 1932b), 4-7.

—. "al-Itijār bi-l-dīn" [Trading in religion]. al-Fath 8, no. 371 (16 Nov. 1932c), 9-12.

"Khalid Sheldrake fī l-Hind: ḥadīth lahu muhim 'an al-shu'un al-Islāmiyya" [Khalid Sheldrake in India: An important talk for him about Islamic issues]. al-Fath 7, no. 326 (5 Jan. 1933d), 6-7.

_. "al-Qadiyāniyyūn-Ba`ḍu ma lahum wa-mā 'alayhim" [The Qadiyanis, the pros and cons]. al-Fath 7 , no. 315 (21 Oct. 1932d), 9-10.

—. "Sabb al-Qadiyāniyyīn li-l-Islām I \& II" [The offense of Qadiyanis to Islam I \& II ] , no. 362 (15 Sept. 1933e), 1-5 and (21 Sept. 1933), 13-16 [[in al-Fath?]] yes...

Honvault, J. "Speaking about Oneself when External Life is Ethically Primordial: The Diary of the Sryo-Lebanese Arab Nationalist 'Ādil Arslān (1887-1954)." In Many Ways of Speaking About the Self: Middle Eastern Ego-Documents in Arabic, Persian, and Turkish (14th-2oth Century), edited by Yavuz Köse and Ralf Herausgegeben von Elger. Wiesbaden: Harrassowitz, 2010.

Hurvitz, Nimrod. "Muhibb ad-Din al-Khatib's Semitic Wave Theory and Pan-Arabism." Middle Eastern Studies 29, no. 1 (1993): 118-134.

Ḥusayn, Muḥammad al-Khiḍr. "Ṭāifa al-Qadyāniyya" [A Qadiyani sect], al-Fatḥ 7, no. 317 (3 Nov. 1932), $1-7$.

Irish Times. "Moslem Funeral Service." 1 September 1928.

al-Khațīb, Muhibb al-Dīn. "Islāmuna wa-Islām al-Qadiyāniyyīn" [Our Islam and the Islam of the Qadiyanis]. al-Fath 7, no. 322 (8 Dec. 1932a): 1-3. 
—. "al-Qadiyāniyya dīn yukhālif dīn al-Islām kamā anna al-Nașraniyya dīn yukhālif dīn al-Yahūd" [Qadiyaniyya: A religion that contradicts Islam just as Christianity contradicts the religion of the Jews]. al-Fath 7 , no. 320 (24 Nov. 1932b): 1-2.

Lavan, Spencer. "Polemics and Conflict in Ahmadiyya History: The 'Ulema, the Missionaries, and the British (1898)." Muslim World 62, no. 3 (1972): 283-303.

Maḥmūd, 'Abd al-Ḥalīm. al-Hamdu li-Llāh hadhihi hayātī. Cairo: Dār al-Ma'ārif, 1985. —. Uruba wa-l-Islām. Cairo: Dār al-Ma'ārif, 1991.

Manchester Guardian. “40,00o For London Mosque.” 27 February 1928.

Manchester Guardian. "Irish Peer converted to Mohametanism." 17 November 1913.

Mayeur-Jaouen, Catherine. "Les débuts d'une revue néo-salafiste: Muhibb al-Dîn alKhatîb et Al-Fath de 1926 à 1928." Revue des mondes musulmans et de la Méditerranée 95-98 (April 2002): 227-255. Online: http://remmm.revues.org/234.

Moch Nur Ichwan. "Differing Responses to an Ahmadi Translation and Exegesis: The Holy Qur'ān in Egypt and Indonesia." Archipel 62 (2001): 143-161.

al-Nabhānī, Taqī l-Dīn. "al-Qadiyāniyya wa-l-falsafa al-hindiyya" [The Qadiyaniyya and Indian philosophy]. al-Fath 8, no. 372 (23 Nov. 1933).

New York Times. "English Moslem Peer Deplores Plane Conversion of Princess." 20 February 1932.

New York Times. "Irish Peer turns Moslem." 16 November 1913.

Observer. "Mohammedan Peer." 16 November 1913.

Rifaat, Mansur. Die Ahmadia Agenten: ein Rätsel. Werden sie tatsächlich von den deutschen Behörden unterstützt und beschützet? (Berlin: Morgen- und Abendland Verlag, 1924a).

- Ahmadi Betrayal of Country and Religion (Berlin: Morgen- und Abendland Verlag, 1923a).

- The Ahmadi Sect: Vanguard of the British Imperialism and the Greatest Danger to Islam, Convincing Evidence of their Duplicity (Berlin: Morgen- und Abendland Verlag, 1923b).

—. Die Ahmadia-Sekte: Ein Vorkämpfer für den englischen Imperialismus (Berlin, 1923c).

- Total Demoralisation of the Ahmadia Sect: Further Evidence in regard to their Activities as British Agents and Menace to Islam (Berlin: Morgen- und Abendland Verlag, 1924b).

- Der Verrat der Ahmadis an Heimat und Religion (Berlin: Morgen- und Abendland Verlag, 1923d).

—. Vollständiger Zusammenbruch der Ahmadia-Sekte: Weitere Beweise für Ihre Tätigkeit als englische Agenten (Berlin: Morgen- und Abendland Verlag, 1924c).

Ryad, Umar. Islamic Reformism and Christianity: A Critical Reading of the Works of Muhammad Rashid Rid̄a and his Associates (1898-1935). Leiden: Brill, 2009. 
"Islamic Reformism and Great Britain: Rashid Riḍā's Images as Reflected in the Journal al-Manār in Cairo." Islam and Christian Muslim Relations 21, no. 3 (2010): $263-285$.

- "From an Officer in the Ottoman Army to a Muslim Publicist and Armament Agent in Berlin: Zekî Hishmat Kirâm (1886-1946).” Bibliotheca Orientalis 63, nos. 3-4 (2006), 235-268.

Saeedullah. The Life and Works of Muhammad Siddiq Hasan Khan, Nawab of Bhopal: 1248-1307/1832-189o with a foreword by H.M. 'Abd al-Quddus Qasmi. Lahore: Sh. Muhammad Ashraf, 1973.

al-Sharīf, Aḥmad. "al-Lahūriyyūn wa-Brītania" [The Lahoris in Britian]. al-Fatḥ 9, no. 423 (29 Nov. 1934), 20-22.

Sheldrake, Khalid. "al-Duktūr Khalid Sheldrake yataḥaddath 'an tārīkh 'alāqatih bi-lIslām wa yu'lin barā’atahu min al-Aḥmadiyya wa-l-Qadyāniyya awalan wa-ākhiran" [Dr. Khalid Sheldrake speaks about the history of his relationship to Islam and clears his name from any connection with the Ahmadiyya and Qadiyaniyya]. al-Fath 8, no. 383 (15 Feb. 1934a), 6-7.

_. "Islam and the Unity of Mankind." Islamic Review 9, no. 10 (Oct. 1921a), $373-376$.

—. "Li-mādha yaḥmilu 'alayya al-Aḥmadiyyūn?" [Why are the Ahamdis against me?]. al-Fath 9, no. 421 (15 Nov. 1934b), 22-23 and al-Fath 9, no. 422 (22 Nov. 1934), 14-15.

—. "The Message to Mankind." Islamic Review 9, no. 1 (Jan. 1921b), 21-24.

- "More 'Massacres"' Islamic Review 10, nos. 6-7 (June/July 1922), 267-270.

. "Muhammad and World Unity." Islamic Review 14, nos. 3-4 (March/April 1926), $148-15^{2 .}$

—. "Mustaqbal al-Islām" [The future of Islam]. al-Fath 9, no. 434 (21 Feb. 1935a), $12-13$.

. "Our Duty To-day." Islamic Review 9, no. 2 (Feb. 1921c), 71-73.

. "Practical Experience of Islam." Islamic Review 9, no. 11 (Nov. 1921d), 420-422.

. "The Religion of Peace." Islamic Review and Muslim India 3 (1915).

"al-Yabān wa-l-Islām al-ḥaqq" [Japan and genuine Islam]. al-Fatḥ 9, no. 439 (5 April 1935b), 18-19.

Straits Times. "Head of Seven Million Muslims Visits Singapore." 26 June 1933.

Times. “British Muslims' Leader Resigns." 12 December 1935. 


\section{Conversion of European Intellectuals to Islam: The Case of Christiaan Snouck Hurgronje alias 'Abd al-Ghaffār}

\section{Pieter Sjoerd van Koningsveld}

In reflecting on the role learned European converts to Islam may play in intercultural communication and Islamic scholarship, it seems useful to distinguish between three main types of conversion. First, there is the permanent conversion, in which the convert acts out of free will and personal conviction and believes that he has converted for the rest of his life. In their new status, these intellectuals also may acquire completely new audiences and with them new chances for a successful intellectual career, especially if they use their talents in the service of combatting their old faith. In fact, numerous polemical and apologetic writings flew from the pens of these erudite converts who attacked their old faith or philosophy of life and defended their choice of Islam. A famous case is Fray ("Brother") Anselm of Turmeda ('Abdallāh al-Tarjumān al-Mayurqī), who authored his famous anti-Christian pamphlet Gift for the Intelligent to Confute the People of the Cross in Tunis, after his conversion to Islam in the latter half of the fourteenth century. ${ }^{1}$ In fact, this phenomenon of learned European converts producing polemical and apologetic writings continues to the present day, as is amply illustrated by the study of Salah Abdel Razaq on neo-Muslim intellectuals in the West; he writes long chapters on their contributions to Islamic polemical, anti-Western, and anti-Christian literature. ${ }^{2}$ Some of the works of these converted polemicists even enjoy distribution on a worldwide scale, in translations into the major languages of the Muslim world. There are, however, some rare exceptions to the majority of these polemical erudites. An example is Leopold Weiss, of Austrian Jewish extraction, who converted to Islam and adopted the name Muhammad Asad, then delved deeply into Arabic and Islamic sources, and ultimately developed

1 'Abdallāh al-Tarjumān al-Mayurqī, Tuhfat al-arīb fì l-radd 'alā ahl al-șalīb, ed./trans. Mikel Epalza (Madrid: Hiperión, 1994), 26-42.

2 Salah Abdel Razaq, Neo-Muslim Intellectuals in the West and Their Contributions to Islamic Thought and the Formation of Western Islam (Leuven: Peeters, 2008), Ch. 5, 229-262, and Ch. 6, 263-212.

(C) PIETER SJOERD VAN KONINGSVELD, 2016 | DOI 10.1163/9789004301979_005 This is an open access chapter distributed under the terms of the Creative Commons 
into an Islamic scholar with a wide recognition, and even translated and commented upon the Qurān. ${ }^{3}$

A second type of conversion frequently observed is forced conversion. Here, the intention of the "convert" usually is to return in due time to his/her original faith or conviction or even to continue his/her original faith or conviction without any interruption but in secret. This results in the phenomenon of a simulated or fraudulent conversion. During the period of slavery, for instance, many enslaved European Christians outwardly converted to Islam under duress. Those who were fortunate enough to escape or be ransomed usually reverted to their original faith immediately upon returning to their home countries. ${ }^{4}$

A third type of conversion to be distinguished is the conversion of convenience. This is an insincere form of conversion performed only to obtain certain interests, like a marriage, access for one's children to a confessional school, access to a certain club or place open to adherents of a particular religion. The fraudulent convert who converts out of convenience may have in mind activities such as espionage, research in the field, love relations, etc. The history of European "conversions of convenience" to Islam is promising and deserves a profound historical study. The earliest example known to the present author dates back to the year 1162, when, according to Arabic sources, two Andalusian Christians (probably Arabic speaking "Mozarabs" from Christian Spain), disguised as Muslims, attempted to dig an underground tunnel in Medina, in order to steal the bones of the Prophet Muhammad and bring these with them back to Spain. They were unmasked and executed. ${ }^{5}$ Another early example is the early sixteenth-century Italian traveler Ludovico di Varthema who as a "temporary convert" was able to provide an eyewitness report of the Prophet's Mosque in Medina with historical explanations in a language that his readers could understand; he described, for instance, Abū Bakr, Muhammad's successor buried next to him, as a "cardinal, who had the ambition to become pope." 6

Each of us can think of some famous examples of a more recent time, like Edward William Lane (1801-1876), who undertook research in the first half of

3 Martin Kramer, "The Road from Mecca: Muhammad Asad (born Leopold Weiss)," in The Jewish Discovery of Islam, ed. Martin Kramer (Tel Aviv: Tel Aviv University, 1999), 225-247.

4 Bartolomé Bennassar et Lucile Bennassar, Les chrétiens d'Allah. L'histoire extraordinaire des rénégats. XVIe-XVIIe siècles (Paris: Perrin, 1989).

5 For a detailed report see, among others: al-Samhūdī, Wafā l-wafẳ bi-akhbār dār al-Muștafā, ed. Qāsim al-Sāmarrāīi (Mecca/Medina: Mu’assasat al-Furqān 1422/2001), 2:431-439.

6 Ludovico di Varthema, The Itinerary of Ludovico di Varthema of Bologna from 1502 to 1508 as Translated from the Original Italian Edition of 1510, by John Winter Jones, F.S.A. in 1863 for the Hakluyt Society (London: Argonaut Press, 1928), xxxiv. 
the nineteenth century into the manners and customs of the Egyptians. Wellknown travelogues of an earlier date, like those of Johann Ludwig Burckhardt (1784-1817) and Richard Francis Burton (1821-1890) could hardly have been written had they not enjoyed the advantages of temporary conversions. Less known is the example of Léon Roches (1809-1900), who would hardly have been successful in gathering fatwās in favor of the French colonial administration, had he not presented himself as a Muslim. He was called "Omar ould Roches" by the leader of the Algerian resistance against the French invasion of Algeria, Prince 'Abd al-Qādir, in 1837 after the latter had married him to a woman from his entourage and had made him his personal secretary. His mission to collect fatwās in Kairouan, Cairo, and Mecca, that authorized Muslims of Algeria to live under French domination, dates back to the early 1840 . After having completed this mission, Roches decided to enter the clergy as a priest and involve himself in the mission. After King Louis Philippe convinced Pope Gregory XVI that he urgently needed the prolonged services of Roches, he left the clergy and was reintegrated into the French army as its chief interpreter. ${ }^{7}$

The Dutch orientalist Christiaan Snouck Hurgronje (1857-1936) is a special case; he accumulated the social and political advantages of a conversion of convenience to its fullest extent, during a long period of his active life. His conversion started as a temporary one but happened to develop into a more permanent form, though it remained restricted to a segment of his network, only. Snouck's half year stay in Mecca (1884-1885) was, probably, initially conceived by him in the framework of a temporary conversion needed only for that stay. It so happened, however, that the further vicissitudes of his life incited him to revitalize his "temporary" conversion after the original date of its expiration, when, in 1889 he went to the Dutch East Indies and stayed there for sixteen years as an official advisor to the Dutch government. There he resumed his Meccan Muslim network and expanded it considerably, also founding a Muslim family with Muslim wives and Muslim children. Here we observe the origins of a double life that continued until his death in 1936. His first and by far the most extensive network were his European contacts, including many orientalists and other academics, in addition to a long list of officials of the Dutch colonial administration. The second network consisted of his Muslim contacts, including prominent religious scholars and members of the ruling class, mainly from Arabia and the Dutch East Indies. ${ }^{8}$

7 Jacques Caillé, Une mission de Léon Roches à Rabat en 1845. Documents inédits avec introduction et commentaires (Casablanca: Kaganski, 1947), 13-14.

8 The previous two paragraphs are a brief summary of my book Snouck Hurgronje en de Islam. Acht artikelen over leven en werk van een oriëntalist uit het koloniale tijdperk (Leiden, 1987), 
Seventy-five years after his death, it seems quite clear that Snouck's major historical influence lies in his contributions to the formation of a colonial Islam policy in the Dutch East Indies. The Republic of Indonesia became the direct heir of the Dutch East Indies as they had been created and forged into one national state from innumerable smaller political entities during the colonial era. Similarly, the Dutch East Indian Islam policies, as well as the institutions developed for them during the colonial period, became the basis of the Islam policies of the Republic of Indonesia after its independence. Jakarta's Ministry of Religious Affairs, for instance, is a direct continuation of the "Office of Religion" or Kantor Agama of the colonial era. ${ }^{9}$ From this perspective, Snouck's Muslim network can be expected to shed light on the colonial prehistory of modern Indonesia, and especially on the origin of its Islamic policies and their related institutions. As Snouck's personal archives are now becoming accessible at Leiden University Library, also in digitalized form, this is the right time for a first exploration of at least the key people in his extensive Muslim network.

Here, one should separate the numerous incidental contacts on the one hand from the much less numerous long lasting contacts, on the other hand. In the many official capacities he occupied: Advisor of Islamic and Native Affairs, first in the Dutch East Indies and later in the Netherlands; Professor of Arabic and Islamic Studies at Leiden University; editor of the Encyclopaedia of Islam published at Brill; Supervisor of the Oriental Manuscripts Collection of the Leiden University Library with the title "Interpres Legati Warneriani"; president of the Dutch Oriental Society—in all these official capacities Snouck was likely to be approached from many sides by people with some specific interest. In the present context we focus exclusively on those long lasting Muslim contacts that occupied a structural place in his biography.

The historical basis of Snouck's Muslim network was certainly his journey to Mecca in the years 1884 and 1885 and his "temporary conversion" to Islam. Towards his European network, Snouck was crystal-clear in "defending" his conversion as a mere instrument to obtain access to Mecca and be accepted in a Muslim society. For instance, in a contemporary letter, dated Mecca, 1 August

292 pp. with bibliography. This book contains a (slightly) revised version of eight articles published in various periodicals between 1980 and 1987. See also the Indonesian edition of this book, Snouck Hurgronje dan Islam. Delapan karangan tentang hidup dan karya seorang orientalis zaman kolonial (Jakarta: Girimukti Pasaka Publishers, 1989), 312 pp.

9 Compare the work of Moch. Nur Ichwan, "Official Reform of Islam: State Islam and the Ministry of Religious Affairs in Contemporary Indonesia, 1966-2004" (PhD diss., Tilburg University, 2006). 
1885, he assured his former teacher, the German orientalist Theodor Nöldeke, that he regularly visited the Kaba, because one could not live in a Muslim society without outwardly behaving as a Muslim, "because the days when Christians or any other scum could live here in freedom, belong to the past."10 And in a later letter to the same teacher, of 27 February 1915, Snouck justifies his Islam as follows:

No, my izhâr al-islâm [my outward Islamic behavior] has nothing in common with the theory that in war all means are permitted. The former is an intransitive measure [i.e., a measure without an object] that in the worst case could harm him who applied it. A measure, in my eyes far more innocent than when one, in a modern society, would partake of the sacraments of a church or desire them for one's children, without attaching to them any value. It is that, which I consider personally as blasphemy, but not the accommodation to the externals of an intellectually inferior society which are necessary in order to be considered there as a human being.... I would regard a similar accommodation to Christian ritual as self-evident in the society of South-African Boers, who also mistrust someone standing outside their religious community and regard him as a wretch. ${ }^{11}$

On another occasion, Snouck referred to his "temporary conversion" in a more indirect way, as follows: "By having studied the theory of Mohammedan law and doctrine and prepared myself for entire accommodation to the practice of Mohammedan manners and customs I was able to 'hide in the full light' as a proverbial saying of Java has it, to constantly observe without being regarded as observer."12 Snouck's own explanations of his Islam towards his European network and his European audience are consistent and fit into the social and political realities of his time. I see no reason to doubt their sincerity. However, a different view was proposed by Jan Just Witkam, who argued that the sincerity of Snouck's Islamic faith cannot be judged scientifically, but must remain a matter between him and his Creator. ${ }^{13}$ But this view is contradicted by Snouck's

10 C. Snouck Hurgronje, Orientalism and Islam: The Letters of C. Snouck Hurgronje to Th. Noldeke from the Tübingen University Library (Published by P.S. van Koningsveld, Leiden, Faculty of Theology, 1985), 8.

11 Snouck Hurgronje, Orientalism and Islam, 222.

12 Snouck Hurgronje, C. "Some of my Experiences with the Muftis of Mecca," in Jaarverslagen 1934-1940 van het Oostersch Instituut Leiden (Leiden, 1941), 4.

13 C. Snouck Hurgronje, Mekka, vertaald en ingeleid door Jan Just Witkam (Amsterdam: Atlas, 2007), especially $75 \mathrm{ff}$. 
own numerous and crystal-clear explanations towards his European network, as well as by his consistent agnostic convictions that are transparent on many pages of his publications throughout his life.

From the Muslim side, Snouck's conversion to Islam was accepted as genuine and sincere, right from the beginning, by some circles at least. When Snouck, after his expulsion from Mecca, feared that mistrust of his conversion might have been a cause, an Algerian acquaintance, 'Azīz b. Ḥaddād, assured him that this was not the case, as "you have publicly announced your conversion to Islam and even the religious scholars of Mecca testified to that" ("li-annaka ashharta islāmaka wa-'ulamā’u Makka yashhadūna bi-dhālika")..14 In certain circles, however, Snouck's conversion became controversial. The famous Egyptian reformist, Muhammad Rashīd Riḍa, for instance, once spoke of Snouck as "an enemy of Islam and a hypocrite who [falsely] pretended to have converted to Islam and had called himself 'Abd al-Ghaffär; he stayed for a while in al-Azhar and went to Mecca where he resided to spy on the Muslims."15 (The episode in al-Azhar is historically incorrect. Riḍā may have confused Snouck with Ignaz Goldziher, who studied for some time in al-Azhar, but without a prior conversion.) Yet, according to the following Muslim personalities and groups who occupy places of pride in his Islamic network, Snouck's conversion was accepted as genuine and sincere.

al-Sayyid ‘Abdallāh b. Muḥammad b. Ṣâliḥ al-Zawāwī (d. 1924)

One highly influential scholar who consistently confirmed and defended the authenticity of Snouck's Islam until his death in 1924, was the Meccan scholar Sayyid 'Abdallāh b. Muḥammad b. Ṣālih al-Zawāwī whom Snouck met in 1884 in Jeddah for the first time, even before entering the city of Mecca. Snouck followed his courses in the Holy City and stayed in contact with him after that. Many years later, after the Turkish revolution and in the period of the rule of Sharif Husayn in Mecca, he was appointed to the highest positions a religious scholar could occupy in Mecca, viz. of Shafi'i mufti and Shaykh al-'ulamä'. It was the already-quoted Rashīd Riḍā, who in an article in his Majallat al-manār acknowledged that "my friend 'Abdallāh al-Zawāwī, the mufti of Mecca, who

\footnotetext{
14 Letter dated 20 Dhū l-Qa'da 1302 (31 August 1885) in the Leiden University Library in portfolio $\mathrm{S}_{32}$ of Cod. Or. 18097, among the Snouck Hurgronje documents transferred from the former Oosters Instituut.

15 M. Rashīd Riḍā, "Ḥālat al-muslimīn fì Jāwa wa-l-iṣlāḥ," al-Manār 14 (1911), 761-767.
} 
was one of his [=Snouck's] teachers, believed in the genuineness of his conversion to Islam." 16

According to some contemporary printed Arabic sources, al-Zawāwī had been expelled from Mecca in the year 1307/1889-189o by Sharif 'Awn because of a conflict that had arisen between them concerning the authenticity of Snouck's conversion to Islam, which Sharīf 'Awn doubted, but al-Zawāwī defended. According to these sources, this forced al-Zawāwi to travel to Java (the Dutch East Indies), Malaysia, China, Japan, and India.. ${ }^{17}$ For his part, Snouck Hurgronje informs us that al-Zawāwì's

intimate connections with Turkish governors and with members of the Sherif family who disliked the Grand Sherif Aun, became ever more evident, so that the latter watched a favourable opportunity to get rid of his opponent. Well knowing that such an opportunity could not fail to come, Sayyid Abdallah secretly put his private affairs in order, and escaped from his birthplace in woman's garb. For about fourteen years his life was that of a wandering scholar; he visited his numerous friends and pupils in British India, in the Straits Settlements, in the Dutch Indies, where we often met. Wherever he came he was gladly received and entertained by his admirers, who in the meantime asked him for fatwâ's on questions of law, and for a couple of years he acted as the official Mufti of the Sultan of Pontianak in Borneo, a prince of Arabic descent. ${ }^{18}$

The extensive collection of al-Zawāwī's Arabic letters to Snouck preserved in Leiden is an eloquent witness of their continuous contacts. These letters were written from different places where al-Zawāwī was staying, among others during his journeys in Southeast Asia: Singapore, Pontianak, Sukabumi, Yokohama, Calcutta, etc. In all of his letters (written in Arabic) which span the period 1894-1917, Snouck is addressed as "Hājjī 'Abd al-Ghaffār [Effendi], may God preserve him" (al-Hājj 'Abd al-Ghaffār [Effendi] hafizahu Alläh), preceded by various expressions of politeness and appreciation..$^{19}$ In 1908, after the Turkish revolution, he returned to Mecca. In addition to the offices of Shafi'i mufti and

16 Rashīd Riḍā, M. "Fatāwī al-Manār (Masā̉il al-libās wa-l-zayy)," al-Manār 26 (1926), 416-424.

17 Aḥmad Shiryāf, "al-Sayyid 'Abdallāh b. Muḥammad Ṣālị̣ al-Zawāwī Muftī l-Shāf'iyya biMakka," Majallat al-Sāda al-Ashräf, vol. 11 (without pagination), and the sources mentioned there: http://www.alashraf.ws/vb/showthread.php?t=46218.

18 Snouck Hurgronje, "Some of my Experiences," $15 \mathrm{f}$.

19 Leiden University Library, Cod. Or. 8952 A: 1117-1127. 
Shaykh al-'ulamā', he occupied the posts of Ra'īs Majlis al-Shūra, and that of Ra'îs Majlis al-Shuyūkh, thus playing a major political role in the period preceding the Saudi era. He was shot in Ta'if in 1924.

\section{Raden Aboe Bakar Djajadiningrat (ca. 1854-1914)}

A key person of an entirely different nature was Raden Aboe Bakar, scion of the noble Javanese family of Djajadiningrat, who became Snouck's personal assistant in Arabia and afterwards. Raden Aboe Bakar had studied for five years under the guidance of 'Abdallāh al-Zawāwī, before he became Snouck's personal "research-assistant." He collected most of the vital information about the Jawi community in Mecca and about Meccan manners and customs which were to form the backbone of Snouck's book on Meccan life in the late nineteenth century. His field work notes are preserved in Leiden. ${ }^{20}$

At Snouck's personal recommendation, Raden Aboe Bakar was officially connected to the Dutch consulate in Jeddah as translator and information officer who, among others, was to provide the Dutch consul with information needed about the Jawi (i.e., Dutch Indian) community in Mecca.

What had made him so employable was his family connections with the Dutch administration in West Java, his connections with the large Jawi community in Mecca, and his fluency in several languages required for dealing with them, namely Arabic, Malay, Sundanese, and Javanese. From then on he served as the leading "native" hand at the consulate, liaising between the Dutch consul and the local authorities, both Ottoman and Sharifan; translating for visiting pilgrims from the Dutch Indies when they called in to register their arrival; and monitoring the activities of the Jawi community in nearby Mecca. ${ }^{21}$

Aboe Bakar was personally involved in preparing Snouck for his conversion to Islam in 1884 , and his letters dating back to the period 1885 to $1912^{22}$

\footnotetext{
20 See my Snouck Hurgronje en de Islam, index s.v. Djajadiningrat, Raden Hadji Aboe Bakar.

21 Michael F. Laffan, Raden Aboe Bakar, "An Introductory Note Concerning Snouck Hurgronje's Informant in Jeddah (1884-1912)," Bijdragen tot de Taal-, Land- en Volkenkunde 155 (1999): 517-542; idem, "Writing from the Colonial Margin. The Letters of Aboe Bakar Djajadiningrat to Christiaan Snouck Hurgronje," Indonesia and the Malay World $3_{1}$ (2003), $35^{6}-380$, especially $35^{8}$.

Leiden University Library, Cod. Or. $895^{2}$ A: 9-13.
} 
witness his conviction of the authenticity of Snouck's Muslim identity; he addressed him, among other titles, as "our brother in God Shaykh 'Abd al-Ghaffār Effendi, may God favor him in both worlds" ("al-Salāmu 'alaykum wa-rahmat Allāh wa-barakātuhu bi-l-dawām 'alā mamarr al-layāli wa-layyām-yukhașșu bi-hadhā ilā hadrat sa'ādat al-'azizz dhī l-majd al-rahīb al-adīb akhīnā fì Allāh al-shaykh 'Abd al-Ghaffār Effendi ballagha Allāhu manānahu fi l-dārayn") (1885). At times, the letters seem to express the subordinate affection of a disciple or of a servant towards his master: "His Highness, the unique person of his age, my fountain-head the great scholar 'Abd al-Ghaffār" ("Haḍrat farìd 'așrihi manbatī l-alläma 'Abd al-Ghaffār") (1891), and, in 1897: "His Highness, the most exemplary model, my highest support Dr 'Abd al-Ghaffār, may his rank be increased" ("Hadrat qudwat al-amāthil 'umdatī l-a'à Dr 'Abd al-Ghaffār zìda qadruhu"), in 1905: "The most exemplary model, his Excellency 'Abd al-Ghaffär, may his wishes continue to be fulfilled" ("Qudwat al-amāthil sa'ādatlu 'Abd al-Ghaffār dāma kamā rāma"; and, finally, in 1909, "Haḍrat 'azizzì l-mufakhkham al-'allāma Dr C. Sn. 'Abd al-Ghaffär Effendì dāma kamā rāma").

In the eyes of a close friend like Raden Aboe Bakar, Snouck's Islam was an indisputable and, of course, also a public fact. By his close connections to Snouck in Arabia and his family connections in circles close to Snouck's women in Java, Raden Aboe Bakar was also informed in detail about Snouck's intimate life in Arabia and Java, including his women and children.

A young West Javanese religious scholar Snouck met in Mecca also played a major role during the remaining period of Snouck's life. First of all, during his seventeen-year stay in the Dutch East Indies, he assisted him, among others, during his field research in the pesantrens or religious schools in Java during the early years of his stay, as well as during his following field research in Acheh. Both research projects resulted in reports with a major influence on Dutch colonial policies. I am referring to the West Javanese scholar Ḥajjī Ḥasan Muștafā, who was in his early forties when he met Snouck (then twenty-eight years old) in Mecca. Hâjjī Hasan had already returned to his country of origin when Snouck joined him in the Dutch East Indies, in 1889.

At my proposal, H. Hasan Moestapha accompanied me in the years 1889-1891 during some of my journeys through Java, and for an important part I owed it to his inappreciable support that I soon was surrounded by 
a wide circle of Natives from the contacts with whom I soon was able to draw the necessary information. ${ }^{23}$

These are Snouck's own words, in appreciation of his friend.

Haajjī Hasan Muștafā was appointed chief penghulu [judge] of Kotaradja in Acheh (North Sumatra) in 1892, at Snouck's recommendation, and regularly reported to Snouck about relevant political and military developments in Acheh, as is witnessed by a bundle of his letters, usually written from Acheh in Arabic to Snouck. ${ }^{24}$ At his request, Ḥasan Muștafā was transferred to the chief penguluship in Bandung some years later, again at the proposal of Snouck. Ḥasan Muștafā was a gifted writer on Sundanese manners and customs, as well as a composer of Sundanese poetry.

Hasan Muștafâ's close contacts with Snouck became the object of polemical articles in the Arab press. A long article in the Cairo weekly Misbāh al-Sharq (29 November 1902, No. 232), written by "one of the prominent Muslims in the lands of Jāwah," asserted, among other issues, that the Dutch government was using the services of Hâajjī Ḥasan Muștafā in order to persuade the local population to leave Islam and embrace Christianity. According to this article, Hasan Mușțafā was spreading various heresies among the people of the villages of West Java, acting under the direct influence of Snouck Hurgronje by whom he was protected personally.

As we shall see later on, Hasan Muștafā was personally involved in arranging both Snouck's Islamic marriages to daughters of the West Javanese nobility. After Snouck left the Dutch East Indies, Ḥasan Mușțafā regularly informed him about his five children whom he had left behind in Java, together with his second wife. An extensive collection of his letters from this period is preserved in Leiden as well. In these letters, Hasan Mușțafā usually avoided mentioning Snouck's name in a direct manner, in accordance with Sundanese etiquette. They nevertheless reflect their intimate, affectionate relationship in which the shared Islamic faith is presupposed. This is witnessed by the addresses of his letters: "Peace be upon you and God's blessings" ("al-Salāmu 'alaykum wa-rahmat Allāh wa-barakātuhu") or "Peace be upon us and upon the pious servants of God" ("al-Salāmu 'alaynā wa-'alā 'ibād Allāh al-șāliḥin"); and elsewhere:

23 C. Snouck Hurgronje, Ambtelijke Adviezen van C. Snouck Hurgronje 1889-1936. Uitgegeven door E. Gobée en C. Adriaanse ('s Gravenhage: Nijhoff, 1957-1965), 1:180. See also P.S. van Ronkel, "Aanteekeningen over Islam en folklore uit het reisjournaal van Dr C. Snouck Hurgronje," Bijdragen Koninklijk Instituut (1942), 311-339.

24 Leiden University Library, Cod. Or. 18097, Portfolio 16. 
Peace be upon you and God's mercy and blessings. To the point now: We already sent you a picture, as a token of friendship and to wish you a happy feast and a feast of those who (by their growing age) repeatedly celebrate it. Therefore, may you and I belong to those accruing and gaining benefits, one year after another, years after years belonging to those who are respected (by men) and accepted (by God). Amen. ("al-Salämu 'alaykum wa-raḥmatAllāhwa-barakātuhu.Ammāba'du:fa-qadșadarat li-janābikum minnā al-șāra wa-l-șāra tahnia wa-mu'ānasa bi-al-ìd al-saìd wa-ìd

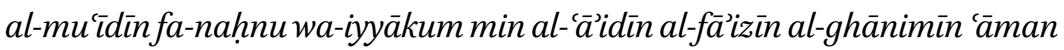
ba'da 'ām, sinīna ba'da sinìn min al-muhtaramin al-maqbütīn, Amīn." $)^{25}$

\section{Sayyid 'Uthmān b. 'Aqīl al-'Alawī (1822-1914)}

At the very center of the key people of Snouck's Muslim network stood the well-known Arab scholar of South Arabian (Hadhramī) origin Sayyid 'Uthmān b. 'Abdallāh b. 'Aqīl b. Yahyā l-'Alawī (1822-1914) of Batavia. From 1889, the year of Snouck's arrival in the Dutch Indies, he was active in the colonial administration (from 1891 in the official capacity of "Honorary Adviser for Arab Affairs"). ${ }^{26}$ Sayyid 'Uthmān's grandfather 'Aqīl had been the head of the Husaynī sayyids in Mecca. He was killed around the year $185^{\circ}$ in the prison of the Grand Sharif of Mecca. Sayyid 'Uthmān himself was born in Batavia, but spent a good part of his youth in Hadramawt and in Mecca. Both in his country of origin and in Mecca he had studied under the most famous teachers. After returning to Java, he gave courses in Islamic jurisprudence and theology in the city of Batavia.

25 The letters dating from the period $1894^{-1911}$ are in Leiden University Library, Cod. Or. $895^{2} \mathrm{~A}, 713$, and $735^{-} 738$.

26 There are many references to the life and work of Sayyid 'Uthmān in Snouck Hurgronje's works. See the indices of his Verzamelde Geschriften en his Adviezen. In recent years, several articles were published on aspects of his biography, among which I mention here Azri Azyumardi, "A Hadhrami Religious Scholar in Indonesia: Sayyid 'Uthmân," in Hadhrami Traders, Scholars and Statesmen in the Indian Ocean 1750s-196os, ed. U. Freitag and W.G. Clarence-Smith (Leiden: Brill, 1997), 249-263. N.J.G. Kaptein, "Arabophobia and Tarekat: How Sayyid 'Uthmân Became Advisor to the Netherlands Colonial Administration," in The Hadhrami Diaspora in Southeast Asia: Identity Maintenance or Assimilation?, ed Ahmed Ibrahim Abushouk, Hassan Ahmed Ibrahim (Leiden/Boston: Brill, 2009), 33-44. Recently, N.J.G. Kaptein published his biography of Sayyid 'Uthmān, entitled Islam, Colonialism and the Modern Age in the Netherlands East Indies: A Biography of Sayyid 'Uthman (1822-1914) (Leiden: Brill, 2015), containing a special chapter on Sayyid 'Uthmān's relations with Snouck Hurgronje (103-140). 
Sayyid 'Uthmān was a gifted and highly productive scholar who published an extensive series of smaller writings, especially fatwās, on his own lithographic press. Snouck Hurgronje regularly relied upon him in many of his advices to the colonial authorities. He occasionally referred to these materials in his published studies, in which he discussed his views on various aspects of modernity and the use of modern techniques in a religious context, for instance on the use of the phonograph for registering and reproducing recitals of the Qurān.

Innumerable times, Sayyid 'Uthmān proved his use as an ally of the Dutch East Indian government, among others when he passed on to Snouck in 1894 a fatwa of the mufti of Johor. In it, the mufti proved from Islamic sources that the Achehnese should stop fighting against the Dutch, because of the great damage that would be done to Islam and Muslims if they continued the war. ${ }^{27}$ Sayyid 'Uthmān's staunch support of Dutch rule comprised, among others, the text of a supplication or $d u^{\prime} \bar{a}^{\prime}$ composed by him for the Dutch Queen Wilhelmina at the occasion of her eighteenth birthday, when she was able to relieve her mother, the Queen Mother Emma, who had acted as her regent of the Dutch Empire. ${ }^{28}$ This prayer was to be read in all the mosques of the Dutch East Indies. It in fact provoked extensive polemical reactions. It is not surprising that the Egyptian reformist Rashīd Ridā incidentally found occasion to criticize Sayyid 'Uthmān as an opponent of his reforms. ${ }^{29}$

Sayyid 'Uthmān's letters to Snouck in Leiden date back to the years 1886 and 1888, shortly after Snouck's return to the Netherlands from Arabia. In these earliest letters, he addresses Snouck as "Mister Snouck Hurgronje" ("al-Khawāja Snouck Hurgronje") (1886) and as "Dr Snouck Hurgronje" ("al-Duktūr Snouck Hurgronje"). In these earliest letters he draws Snouck's attention to his own publications and to the place of authority he occupies among the native Muslims in Jāwa who consult him in their religious and legal difficulties. He refers to the assistance he occasionally lent to the Dutch authorities when they wanted to investigate the mystical brotherhoods, and asks Snouck to recommend him for the official position of advisor or "mufti." As we saw earlier, after Snouck's arrival in the Indies, in 1889, Sayyid 'Uthmān in fact did become his right hand, in the position of "Honorary Advisor of Arab Affairs."

27 Sālim b. Aḥmad b. Muḥsin b. Bū Bakr al-'Ațțās, Risālat al-taslīm wa-l-qitāl wa-l-radd 'alā man aftā bi-ghayri istidlāl, privately owned manuscript in the Netherlands. A photocopy is in the possession of the present author.

28 A full study is provided by Nico J.G. Kaptein, "The Sayyid and the Queen: Sayyid 'Uthmân on Queen Wilhelmina's Inauguration on the Throne of the Netherlands in 1898," Journal of Islamic Studies 9, no. 2 (1998): 158-177.

Rashīd Rị̣ā, "Ḥālat al-muslimīn fĩ Jāwa." 
When Snouck returned to Leiden, and thus after having known him personally for many years in the Dutch East Indies, Sayyid 'Uthmān addressed him as follows: "His Highness, the venerable, most beloved and profound friend Professor 'Abd al-Ghaffār, may his fame and honor endure, his days be fruitful and the signs (of his prestige) be advanced. Amen" ("Hadrat al-mukarram al-muhibb al-adwam wa-l-șăhib al-aḥkam al-Profisūr 'Abd al-Ghaffār dāma 'izzuhu wa-ïlāluhu wa-țābat ayyāmuhu wa-àlà a'lāmuhu-Aminn") (1906), and in 1909 as follows:

I convey many greetings and express deep appreciation (informing you that there is nothing like the longing to see a noble friend, for whom there is no substitute), to his Esteemed Highness, both in essence and in properties, our beloved companion Professor 'Abd al-Ghaffār, may his honor endure and his rank be increased, and his prestige raise high in regions zand cities ("Ahdī al-salām al-jazìl wa-l-thanā' al-jamül (ma'a al-inbä' bianna al-shawq ilā ru’yat al-ṣadìq al-nabìl laysa lahu mathïl haythu lam yūjad lahu badīl) ilā hạdrat al-aziz dhātan wa-șifātan muhibbinā wa-anisinā al-Profisūr 'Abd al-Ghaffār; dāma izzuhu wa-zìda qadruhu wa-'alà șituhu fíal-aqțār wa-al-amșāro').

A selective analysis of the key persons of Snouck's Muslim network must pay some special attention to the role of women in Snouck's life in Mecca and the Dutch East Indies. As we presently see, these women are likely to have strengthened his social position considerably.

During his stay in Mecca, Snouck succeeded in buying an Ethiopian slave girl with whom he lived together and to whom he incidentally referred as his "family" (between inverted commas) and whose name has remained unknown, so far. Snouck praised her, among others, by stating that "fortunately she does not show any of the unpleasant peculiarities of which her race is sometimes accused. It is a fact," Snouck continued,

30 The contents of this paragraph are a brief extract of the more extensive data provided in my book Snouck Hurgronje en de Islam, especially Ch. 5, 131-142, mainly based on my interviews of Snouck's descendants in Bandung, in January 1983. The extract is preceded by the new information concerning Snouck's Ethiopian slave girl in Mecca, which was provided for the first time by Jan Just Witkam, in the introduction to his Dutch translation of Snouck's Mekka (2007). 
that the experts here prefer the good Abyssinian girls over the daughters of the people [of Mecca], to the great irritation of the latter. From my part, I decided to follow this example mainly because each day my knowledge about the excessive demands and the devilish tricks of the daughters of the Holy City is increased, and also because I am able to inform myself about their life and customs without involving myself into more intimate ties with them.

In the Dutch East Indies, many Dutchmen lived with indigenous concubines. Their mixed descendants constituted the specific social group of the so-called "Indos." Often, a Dutchman would leave his concubine with their children behind in the Dutch Indies, when, at the completion of his service, he repatriated to the Netherlands. The case of Snouck's Islamic marriages with daughters of the Javanese aristocracy was different in some important aspects, but similar in other aspects. Shortly after his arrival in Java, he married the daughter, Sangkana, of the local chief panghulu (or chief $q \bar{a} d \underline{\imath} \bar{c}$ ) of Ciamis, Raden Hājjji Muhammad Țāib. She gave him four children, Salmah Emah, Oemar, Aminah, and Ibrahim. She died in 1896, when she had a miscarriage of a fifth child. Press articles that soon appeared in Dutch Indian newspapers of early 1890 accused Snouck of cheating the local population and demanded appropriate measures from the government. These articles stated that the marriage had been concluded in the Friday Mosque of the town. Snouck denied the reports in writing, as did the governor general of the Dutch East Indies.

A second Islamic marriage was concluded by Snouck in 1898, with Siti Sadijah, then thirteen years old, the only daughter of Raden Ḥajji Muhammad Soeèb, vice-panghulu at Bandung, who was known, among others things, as a gifted reciter of the Qurāan on 'Id al-Fițr in its Friday Mosque. From this marriage was born one son, Joesoef, in 1905, whom I visited in Bandung in the 1980s. He confided to me the story of Snouck's Muslim families, which, until then, had been kept strictly secret in the Netherlands. When Snouck left for the Netherlands in 1906 he had made financial arrangements for the maintenance of his children and second wife, while Ḥâjjī Ḥasan Muștafā, who had been the marriage-maker in both cases, kept an eye on them and informed Snouck about their vicissitudes.

\section{Conclusion}

Snouck's conversion of convenience was perhaps the most successful case in colonial history of the instrumentalization of Islam for the benefit of the 
Islamic policies of the rulers and for the development of ethnological field studies. The second volume of Snouck's book on Mecca, dealing with the daily life of Mecca, could not have been completed without it, even though much of the data were gathered after his departure from the Holy City by his assistant Raden Aboe Bakar. Snouck's major books on the Achehnese as well as the Gayonese, could not have been written without the advantages of his conversion, neither could he have given the great majority of his advice to the colonial government. The key people of his Muslim network, each in their own sphere of influence, contributed considerably, not only in establishing and consolidating his social position within Muslim circles, but they also contributed to his authority among Muslims of the Indonesian archipelago at large. He soon acquired the prestige of a Muslim religious scholar himself. Whoever understands the social impact of a network like that of Snouck cannot be surprised at all to find petitions in his archive addressed to him in Batavia as "the Mufti of Batavia," "Muftĩ Jāwa" (= the mufti of the Dutch Indies), and even as "Shaykh al-Islām fì l-Diyār al-Jāwiyya."31 All of these addresses are reflections of the widespread recognition of Snouck as a Muslim and indeed as a Muslim scholar, as sanctioned by a wide range of Muslim scholars of the highest rank.

\section{Bibliography}

\section{Archival Sources}

Leiden University Library, Cod. Or. 8952A: Private Letter Archive of Snouck Hurgronje. All documents referred to from this archive in the present article are now online and accessible through the catalogue of the Leiden University Library.

Leiden University Library, Cod. Or. 18097: Archive of Snouck Hurgronje, in 65 portfolios. Documents referred to from this archive in the present article are not (yet) accessible online.

\section{Secondary Sources}

Abdel Razaq, Salah. Neo-Muslim Intellectuals in the West and Their Contributions to Islamic Thought and the Formation of Western Islam: An Exploratory Investigation of the Religious and Literary Activities of Western Neo-Muslim Intellectuals. Leuven: Peeters, 2008.

31 Leiden University Library, Cod. Or. 18097, Portfolio 1. 
Azyumardi, Azri. "A Hadhrami Religious Scholar in Indonesia: Sayyid 'Uthmân." In Hadhrami Traders, Scholars and Statesmen in the Indian Ocean 1750s-196os, edited by U. Freitag and W.G. Clarence-Smith, 249-263. Leiden: Brill, 1997.

Bennassar, Bartolomé and Lucile Bennassar. Les chrétiens d'Allah. L'histoire extraordinaire des rénégats. XVIe-XVIIe siècles. Paris: Perrin, 1989.

Caillé, Jacques. Une mission de Léon Roches à Rabat en 1845. Documents inédits avec introduction et commentaires. Casablanca: Kaganski, 1947. (= « Publications de l'Institut des Hautes-Etudes Marocaines », tome 43).

Kaptein, Nico J.G. "Arabophobia and Tarekat: How Sayyid 'Uthmân Became Advisor to the Netherlands Colonial Administration." In The Hadhrami Diaspora in Southeast Asia: Identity Maintenance or Assimilation?, edited by Ahmed Ibrahim Abushoul, Hassan Ahmed Ibrahim, 33-44. Leiden/Boston: Brill, 2009.

Kaptein, Nico J.G. Islam, Colonialism and the Modern Age in the Netherlands East Indies: A Biography of Sayyid 'Uthman (1822-1914). Leiden/Boston: Brill, 2014.

Kaptein, Nico J.G. "The Sayyid and the Queen: Sayyid 'Uthmân on Queen Wilhelmina's Inauguration on the Throne of the Netherlands in 1898." Journal of Islamic Studies 9, no. 2 (1998): 158-177.

Koningsveld, P.S. van. Snouck Hurgronje en de Islam. Acht artikelen over leven en werk van een oriëntalist uit het koloniale tijdperk. Leiden, 1987.

Koningsveld, P.S. van. Snouck Hurgronje dan Islam. Delapan karangan tentang hidup dan karya seorang orientalis zaman kolonial. Jakarta: Girimukti Pasaka Publishers, 1989.

Kramer, Martin. "The Road from Mecca: Muhammad Asad (born Leopold Weiss)." In The Jewish Discovery of Islam, edited by Martin Kramer, 225-247. Tel Aviv: Tel Aviv University, 1999 .

Laffan, Michael F. "Raden Aboe Bakar: An Introductory Note Concerning Snouck Hurgronje's Informant in Jeddah (1884-1912)." Bijdragen tot de Taal-, Land- en Volkenkunde 155 (1999): 517-542.

Laffan, Michael F. "Writing from the Colonial Margin. The Letters of Aboe Bakar Djajadiningrat to Christiaan Snouck Hurgronje." Indonesia and the Malay World 31 (2003): $35^{6-380 .}$

Ludovico di Varthema. The Itinerary of Ludovico di Varthema of Bologna from 1502 to 1508 as Translated from the Original Italian Edition of 1510, by John Winter Jones, F.S.A. in 1863 for the Hakluyt Society. London: Argonaut Press, 1928.

al-Mayurqī', 'Abdallāh al-Tarjumān. Tuhfat al-arīb fíl-radd 'alā ahl al-șalīb. Edited and translated by Mikel Epalza. Madrid: Hiperión, 1994.

Nur Ichwan, Moch. "Official Reform of Islam: State Islam and the Ministry of Religious Affairs in Contemporary Indonesia, 1966-2004." PhD dissertation, Tilburg University, 2006.

Rashīd Riḍā, M. "Fatāwī al-Manār (Masāill al-libās wa-l-zayy)." al-Manār 26 (1925), 416-624. 
Rashīd Rị̣ā, M. "Hālat al-muslimīn fī Jāwa wa-l-ișlāḥ." al-Manār 14 (1911), 761-764.

Ronkel, P.S. van. "Aanteekeningen over Islam en folklore uit het reisjournaal van Dr C. Snouck Hurgronje." Bijdragen Koninklijk Instituut (1942), 311-339.

Sālim b. Aḥmad b. Muḥsin b. Bū Bakr al-'Aț̣āas. Risālat al-taslīm wa-l-qitāl wa-l-radd 'alā man aftā bi-ghayri istidlāl. Privately owned manuscript. A photocopy is in the possession of the present author.

al-Samhūdī. Wafā l-wafā̀ bi-akhbār dār al-Muștafā. Edited by Qāsim al-Sāmarrāīi 5 vols. Mecca/Medina: Mu'assasat al-Furqān, 1422/2001.

Shiryāf, Aḥmad. al-Sayyid 'Abdallāh b. Muḥammad Șālị̣ al-Zawāwī Muftī l-Shāfi'iyya bi-Makka. Majallat al-Sāda al-Ashrāf, vol. 11. Available online: http://www.alashraf .ws/vb/showthread.php? $\mathrm{t}=46218$.

Snouck Hurgronje, C.- Ambtelijke Adviezen van C. Snouck Hurgronje 1889-1936. Uitgegeven door E. Gobée en C. Adriaanse. 3 vols. 's Gravenhage: Nijhoff, 1957-1965 ('s Rijks Geschiedkundige Publicatiën 33-35).

Snouck Hurgronje, C. Mekka vertaald en ingeleid door Jan Just Witkam. Amsterdam: Atlas, 2007.

Snouck Hurgronje, C. Orientalism and Islam: The Letters of C. Snouck Hurgronje to Th. Noldeke from the Tübingen University Library. Published by P.S. van Koningsveld. Leiden, Faculty of Theology, 1985.

Snouck Hurgronje, C. "Some of my Experiences with the Muftis of Mecca." In Jaarverslagen 1934-1940 van het Oostersch Instituut Leiden. Leiden, 1941. 


\title{
Muslim Bodies in the Metropole: Social Assistance and "Religious" Practice in Interwar Paris
}

\author{
Naomi Davidson \\ Introduction
}

This paper examines the interwar origins of Muslim histories in metropolitan France. It argues that the seeds for the racialization of people identified as Muslim in France were laid during this period with the creation of a mosque and other "Muslim" sites in Paris. By examining the creation and management of these Muslim spaces by French officials and North African religious leaders we are able to write a transnational history of Islam in Europe, one that acknowledges Islam's long presence in European social and political life. In acknowledging not only the role of French colonialism, but also that of Muslim leaders and by elaborating on what I call "French Islam," we discover how this collaborative construction of a particular vision of Islam ultimately contributed to the process of essentializing those people identified as "Muslim."

I examine the Paris Mosque (Mosquée de Paris) and the Franco-Muslim Hospital (Hôpital Franco-Musulman), built between 1922 and 1935, in order to understand the elaboration of this particular vision of French Islam that blended "Muslim" and "French" civilizations. French Islam inscribed Islam firmly within a French republican model, yet it simultaneously maintained Islam outside the boundaries set by French secularism. The architectural and aesthetic plans for the Mosque, as well as the events that marked the milestones in its development, were essential to the creation and diffusion of French Islam. In this paper I argue that the social service and policing programs that emerged as satellites of French Islam's most important site, the Paris Mosque, used Islam as the basis for their differential treatment of North Africans. In doing so, they set in motion a pattern in which the segregation of immigrants from the Maghrib was portrayed as protective and as preferential treatment based on religious difference. In other words, it was the panoply of interwar social programs that depended on the establishment of the Paris Mosque that helped establish Muslims as only and eternally Muslims in metropolitan France. 


\section{Building the Paris Mosque, Building French Islam}

In the aftermath of World War I, French social scientists, orientalists, and politicians began to articulate a vision of Islam, and Muslim practices, that they hoped would communicate Paris' respect for and commitment to its empire's Muslim subjects. This vision, which I call French Islam, blended French republican principles with French understandings of Sunnī Islam as practiced in Morocco, and emphasized the embodied practices they argued were integral to the proper performance of Muslim religious ritual. The French emphasis on these embodied religious practices transformed an ostensibly religious identity into a racialized one over the course of the twentieth century. At the center of the story of this process of racialization is the Paris Mosque, a "cathedral" mosque built in the immediate aftermath of World War I by metropolitan and colonial leaders in cooperation with a transnational Muslim elite. The Islam embodied by the Paris Mosque served as the exclusive medium for the French state's management of its interactions with Muslim subjects residing in the metropole during the 1920 s and 1930 .

The Paris Mosque and its Muslim Institute were first conceived as a war memorial to be built in the shadow of Les Invalides, where the French army honored its greatest military heroes. Locating the complex near France's shrine to its military victories was intended to reflect the sacrifices made by North and West African colonial soldiers during World War I, as well as to render the complex easily accessible to elite Muslims visiting Paris. The architecture of this "durable monument" was expected to conform to the "artistic demands" of a grand capital. ${ }^{1}$ When the ground for the construction site was broken six years later, in the $5^{\text {th }}$ arrondissement across from the city's natural history museum, the site had been reimagined as a reproduction of a mosque in $\mathrm{Fez}$ that would be built alongside French civilization's most hallowed institutions of learning rather than the shrine to its military successes. The Paris Mosque was not merely a religious site, it was a monument to France's power in the Muslim world, built to reflect its vision of Islam and Muslims. As such it was a "repositor[y] of meaning" where a wide range of events inscribed France's relationship with its Muslim subjects on a daily basis. ${ }^{2}$ The placement of the Mosquée's complex in the cradle of French civilization, and its "Muslim

1 "Une Mosquée à Paris," Ministère des Affaires Etrangères, Direction des Affaires Politiques et commerciales, 22 September 1916, SHAT 7 N 2104, Divers 1916-1917. This text, particularly the above citation, is drawn from Paul Bourdarie's "L'Institut Musulman et la Mosquée de Paris," La Revue Indigène (Oct.-Nov. 1919).

2 Daniel Sherman, The Construction of Memory in Interwar France (Chicago: University of Chicago Press, 1999), 216. 
architectural character" visually signaled the tension between its role as a secular cultural and religious institution that defined the paradox of French Islam.

The two sites were the fruits of contentious collaboration involving the Ministry of the Interior, the Ministry of Foreign Affairs, the Ministry of War, the city of Paris, and the colonial and protectoral administrations of Algeria, Morocco, Tunisia, and French West Africa. Importantly, in addition to the metropolitan and colonial administrations, a group of elite Muslims from the Maghrib and West Africa participated in the elaboration of this project. This group, known as the Society of Habous and Sacred Places of Islam (Société des Habous et des lieux saints de l'Islam), was headed by the Algerian-born Abdelkader ben Ghabrit, more commonly known as Si Kaddour. Si Kaddour was awarded the leadership of the group, and thus, of the Mosque and Institute, not because of his theological erudition or history of religious leadership. Rather, his presidency depended on the political connections he had made in Resident General Lyautey's Moroccan protectorate through his tenure as the sultan's master of protocol. It is thus important to note that $\mathrm{Si}$ Kaddour and the other Muslim leaders who participated in the creation of French Islam were not necessarily well-regarded by their fellow Muslims, on either side of the Mediterranean.

This collaborative vision of French Islam, a system of belief and ritual that was at once particular to Muslim civilization but compatible with French republican ideals and secularism, was to be instantiated in the site of the Paris Mosque. For French connoisseurs of Islam, it was in Morocco that this "rejuvenated Islam" originated from an Islam magnificent in "its isolation, its archaism, which...brings it closer to the purest [Muslim] belief." This purest form of Islam existed in a country that, through its encounter with "modern life," was "adapting to progress" with France's help. ${ }^{3}$ Moroccan Resident General Lyautey argued that this encounter was possible because Morocco and France were both civilizations that respected their ancient traditions while being open to progress. Like the French, he explained, the Moroccans had "an enlightened bourgeoisie...very concerned with progress, most especially economic progress." ${ }^{4}$ But in addition to these similarities between elites on both sides of the

3 René Weiss, Récéption à l'Hôtel de Ville de Sa Majesté Moulay Youssuf, Sultan du Maroc, Inauguration de l'Institut Musulman et de la Mosquée de Paris (Paris: Imprimerie Nationale, 1927), 2, XXv.

4 Ibid., 36. President Doumergue also celebrated the friendship between "the Muslim elite and the French elite" in his speech. At no point in the creation of the Mosquée were non-elite Muslims on either side of the Mediterranean taken into account, other than that they were solicited for donations. As we will see, this was one of the reasons the Mosquée was critiqued by nationalist leaders. 
Mediterranean, proponents of the Mosque argued that Islam and French republicanism shared many traits. Si Kaddour asserted that "respect for morality" and the "glorification of charity" were principles dear to both Islam and a French civilization whose greatest concern was equality. ${ }^{5}$ French President Doumergue made the link between the philosophical underpinnings of French and Muslim culture more explicit:

[Equality] ...of human consciences and of their sincere impulses, is the mark of our democracy; the Muslim savants, as we know, have exalted the respect of individual dignity and human liberty. They have called for...the reign of a large fraternity and of equal justice. Democracy has no fundaments other than these. ${ }^{6}$

There was a clear attempt to identify Islam as compatible with democracy, tolerance, equality, and individual liberty.

It was the Mosque, rather than the Institute, that did the work of remaining bound to "Muslim" tradition as filtered through French perceptions of Moroccan Muslim aesthetics and practices. When its proponents discussed the Mosque's creation, they did not situate it in the heart of Paris's university district: that was the space occupied by the Muslim Institute, whose Islam was intellectual, modern, and compatible with French republicanism but whose physical design was never described. The Mosque, on the other hand, was not discursively located in a particular part of Paris, other than in its center. Although it was necessary that the site be visible to visitors in Paris' landscape, its geographical location was far less emphasized than its design. Its aesthetic character was of primary importance because the Mosque represented an Islam that its French proponents believed had a "hold on its faithful" and controlled all aspects of their lives. It required of its believers that they perform certain practices in particular settings because of the inextricable link between religious practices and daily life. ${ }^{7}$ Its architects hoped to ensure the Mosque's appeal to Muslims by designing it in a "Moroccan" style that would respond to their aesthetic ideals, although contemporary observers were quick to point

5 Si Kaddour's speech at the Mosquée's groundbreaking ceremony, cited in Weiss, Récéption à l'Hôtel de Ville de Sa Majesté Moulay Youssef, 49.

6 Doumergue's speech at the groundbreaking ceremony, ibid., 70.

7 Letter from Saint Aulaire to Ministre des Affaires Etrangères, 7 January 1916, AN Fonds Lyautey 475 AP/95/Lettres au département 1916. See also Commissariat Général à l'Information et à la Propagande. "Projet de loi relatif à l'édification à Paris d'un Institut Musulman" (undated), AMAE Afrique 1918-1940/Affaires musulmanes/11. 
out its appeal to Parisian and other tourists, comparing it both to tourist attractions in North Africa and metropolitan expositions and fairs.

The Mosque's architects chose to give the building the "traditional hispanomauresque" style in vogue among Lyautey's Service des Beaux Arts architects in the Moroccan protectorate. ${ }^{8}$ It was in Morocco, critics agreed, that "a new architecture [was] born... [a] collaboration between French science and intelligence with indigenous craftsmanship and tradition."9 In October $1920 \mathrm{Si}$ Kaddour met with architects in Rabat who specialized in buildings with "Muslim character," in order to prepare the preliminary plans for the Mosque and its annexes. ${ }^{10} \mathrm{~A}$ few months later, he reported back to the Ministry of Foreign Affairs that the Moroccan members of the Society of Habous had unanimously decided that the Mosque should have "an African architectural character" and, more specifically, that it should be modeled on Fez's fourteenth-century mosque-madrasa Bou Inania. Sultan Abou Inan hoped to reorient the city's religious geography by building the complex near the boundary between the old and new cities and thus drawing people away from some of the older mosques. Yet although the Inspector of Beaux Arts wrote that the site was "undoubtedly the biggest and most sumptuous [mosque] of all Morocco," its decoration was not as refined and artistic as that of Fez's older mosques." The sources that refer to the decision to use Bou Inania as the model for the Mosque complex mention the physical beauty and renown of the Fassi site but do not refer to its founder's attempt to remake his city's religious landscape or to the site's relative aesthetic weakness compared to older mosques. It would be intriguing to know whether they were conscious of the ramifications of their choice of this particular institution as a model for Paris's mosque.

Once this model had been chosen, the French architects were given blueprints of this famous institution to inspire their first attempts at plans for the Parisian mosque, whose layout is clearly based on that of Bou Inania. ${ }^{2}$

8 The Mosquée's original plans were drawn by the former director of the Service, Maurice Tranchant de Lunel, and another member, Maurice Mantout, was part of the team whose design was ultimately used.

9 Henri Descamps, L'Architecture moderne au Maroc (Paris: Librairie de la Construction moderne, 1931), 1.

10 Letter from Si Kaddour to Leygues, 6 October 1920, AMAE Afrique 1918-1940/Affaires musulmanes/11.

11 Didier Madras and Boris Maslow, Fès, Capitale artistique de l'Islam (Casablanca, Morocco: Editions Paul Bory, 1948), 134-135.

12 Letter from Si Kaddour to Leygues, 27 December 1920, AMAE Afrique 1918-1940/Affaires musulmanes/11. One of the Mosquée's architects, Mantout, also wrote to Leygues to tell him that the Mosquée was inspired by "one of the most beautiful specimens of Moroccan 
This resonated with metropolitan architectural critics, one of whom noted approvingly that "Muslim constructions, unlike ours, have not evolved and must, on the contrary, remain traditional."13 Lyautey's Morocco was a virtual laboratory for modernist architecture and urbanism in a colonial setting, as Gwendolyn Wright has argued. Under his residency, the Service des Beaux Arts instituted an energetic campaign to preserve entire districts, virtually freezing Moroccan medinas in time, and to "restore" and "reproduce" monuments and other sites that had fallen into disrepair. Wright also argues that the Service, especially under the leadership of Tranchant de Lunel, "oriented itself towards charming streetscapes that would appeal to French residents and tourists." ${ }^{14}$ The architectural style of the Mosque and the fact of it being built to recreate, as closely as possible, a specific Moroccan religious site at once identified Islam as immutable and unchanging and turned the building into a spectacle to be enjoyed by non-Muslim Parisians. ${ }^{15}$

The popular press quickly touted the tourist potential of the Mosque. One observer wrote in the Catholic journal En Terre d'Islam of the "veritable enchantment" of the Paris Mosque: "in penetrating these courtyards and richly decorated rooms, one has more of an impression of visiting a museum than of entering a place of prayer."16 The reference to visiting a museum is important, for despite the intentions of the Mosquée's founders that the site serves a purely pedagogical function, many Parisians viewed it as a site for the display and consumption of Islam. In fact, the Mosque also bore some

architecture." See, in the same box, Maurice Mantout, "Note descriptive de la Mosquéeet de ses dépendences," 12 August 1922.

13 Antony Goissaud, "L'Institut musulman et la Mosquée de Paris," La Construction moderne 3 (2 November 1924), 52 .

14 Gwendolyn Wright, The Politics of Design in French Colonial Urbanism (Chicago: University of Chicago Press, 1991), 134.

15 As Justinard put it in his thesis on the Mosquée, “Isn't it...paradoxical that it's easier for a Christian who wants to see a Muslim religious building to penetrate a mosque in Paris than in North Africa, where most mosques are closed to non-Muslims?" Here an analogy is made between the situation in Morocco (where under Lyautey's protectorate mosques were "protected" from visits by non-Muslims) and that of the rest of the territory. The refusal to allow non-Muslims to enter mosques is not a feature of Islam and was not even applied uniformly in the French empire. However, it is instructive that Justinard made this remark, for many of the tourists who visited the Mosquée may well have been disappointed by their inability to do so in Morocco and hoped to see "the same thing" back home. Pierre Justinard, "La Mosquée de Paris" (MA thesis, Ecole nationale de la France d'outre-mer, 1944), 57 .

16 Georges Buchet, “La Mosquée de Paris," En Terre d'Islam 34 (January 1930), 30. 
resemblance to the colonial expositions, although unlike the exhibits constructed there, the Mosque was set in Paris's landscape permanently and could be visited again and again. The very mosaics used to adorn the site had appeared at the Moroccan pavilion at the 1922 Colonial Exposition in Marseille, as a gift from Lyautey. ${ }^{17}$ One newspaper promised its readers, in its review of the Mosque, "it will provide a change for Parisians from the cardboard boxes with which one pretends to convey, in expositions, the splendor, the mysterious charm of the intimacy of African houses."18 L'Illustration urged those who had traveled in the Muslim world to visit the Mosque in order to experience anew their memories of the food and decor they had so enjoyed. ${ }^{19}$ From the beginning, the Mosque's founders planned to charge non-Muslim visitors admission to the site; this contributed even more to the idea that it was an exhibit to be consumed publicly. Fresh from their success, the Mosque's architects went on to design both the North African pavilions of the $193^{1}$ Colonial Exposition and the Franco-Muslim Hospital in Bobigny that opened in 1935; its façade greatly resembled the Mosque's aesthetics. Clearly, in many peoples' minds, the Mosque was the highlight of a set of sites around the capital that provided visitors with an exoticized image of Islam and Muslims.

The events organized by the French state in collaboration with Si Kaddour and the colonial administrations contributed to the creation of a "secular" Islam in the sense that "religious" events were folklorized, rendered public, and emptied of their original significance, all the while ostensibly occupying the central space of the Mosque's activities. The ceremonies surrounding the Mosque's landmark moments (the groundbreaking, orientation, and inauguration) served as a way to mark both the place of the complex in Paris's geography of significant monuments and the relationships among metropolitan, colonial, and Muslim dignitaries. In addition to these landmark events associated with milestones in the Mosque's construction, other occasions also served as opportunities to shore up metropolitan and colonial relations, particularly with Morocco. A note from the police dated 26 June 1930 reports that a "Fête de charité "Nord-Africaine" ("North African" Charity Event) would take place in the Mosque's confines the following day, under the patronage of the wife of

17 Additional mosaics were required, and Si Kaddour organized for them to be transported from Morocco. In addition, he successfully argued that it was necessary to bring Moroccan artisans to Paris to complete the decoration of the site. See letter from Si Kaddour Ben Ghabrit to Poincaré, 13 March 1923, AMAE Afrique/Affaires musulmanes/12.

18 Le PetitJournal, 25 February 1922.

19 “Un décor d'Orient sous le Ciel de Paris," L'Illustration (26 November 1926), 582. 
Morocco's resident-general. The soirée was designed to raise funds for the Red Cross's work with the indigènes, or Muslim "natives."20 The Mosque was also a privileged site for drawing the Moroccan elite, especially the young generation, closer to France. Even before the site was completed, it was an important stop during tours of Paris taken by Moroccan students. During a 1923 visit, students followed an "interesting" visit to the museum at the Botanical Garden with a tour of the construction site led by one of the Mosque's three architects. The group's leader noted that "we recognized many of Fez and Meknes' master mosaicists, who offered us mint tea." By 1925, the students were apparently "thrilled" with "this corner of Morocco, completely charming with its patios, gardens, water jets, beautiful galleries" and proud that "European visitors do not hide their admiration."21

The events designed to showcase the Mosque also highlight that it was built in the French capital during a period in which metropolitan-colonial questions were particularly fraught. Nowhere is the local battle to place Paris at the heart of the French empire more evident than in Paris City Council Member Pierre Godin's campaign in support of the city celebrating the centenary of the conquest of Algeria. Although his omission of the Mosque itself as a site contributing to Paris's importance in the colonial Muslim world is shocking, his comments about the relationship between the city and the North African colonies are important to understand the space the Mosque occupied in the city as a synecdoche of France. For, as Godin argued, "Algeria is not only...a province of French thought, but an enthusiastic department of Parisian thought. And Paris is enchanted by its animating influence."22 Although he was primarily interested in bringing groups of students to Algeria to witness French progress in action, Godin also hoped to create Parisian venues for the exhibit of Algerian art, crafts and architecture, and literature. The celebration of the Mosque as a credit to Paris's cachet as the heart of the Muslim world certainly supports Gary Wilder's suggestion that we see Paris as "a fundamentally imperial city" in

\footnotetext{
20 Note from 26 June 1930, APP E ${ }^{\mathrm{b}}{ }_{125} /$ Aït el Kébir.

21 Paul Marty, "Mission d'étudiants marocains, août 1923" and "Voyage en France des Etudiants Marocains 1925," AN Fonds Lyautey 475 AP 171/13: Voyages des Marocains civils en France, juillet 1922.

"Note sur la participation de Paris aux manifestations du Centenaire de l'Algérie et sur les dispositions prises par la Commission du centenaire pour assurer cette participation conformément aux déliberations du Conseil Municipal des 11 juillet et $3^{1}$ décembre 1929, présentée par Pierre Godin, Conseiller Municipal, Président de la Commission Municipale du Centenaire de l'Algérie." Rapports et documents du Conseil Municipal de Paris, 20 March 1930.
} 
a metropole that was itself "the very center of an empire of which it and its colonies were integral parts." 23

The Paris Mosque, then, was the product of collaboration among the French state, colonial administrations, and a hand-picked group of North and West African Muslim elite men led by the Algerian-born Si Kaddour. ${ }^{24}$ It was very much a product of its time: fears of being eclipsed by England and Germany as a power in the Muslim world propelled France's metropolitan and colonial administrators into providing tangible evidence of their Muslim politics. The Muslim elites who acted as intermediaries between Muslims and the colonial administrations saw their participation as a way to prove their loyalty to France and increase their own prestige. Yet what began as a fairly straightforward political move in response to external threats quickly became something much more complex. The Mosque de Paris became the physical embodiment of a "new" Islam, one compatible with the principles of secularism and rational modernity while rooted in "traditional" Moroccan Islam. Although it was originally justified as a gesture of recognition for the sacrifices made by colonial soldiers, chance dictated that the Mosque would come to be built in the heart of the Latin Quarter. This allowed the Mosque's proponents to use the site as a theater for the display of French Islam: the Muslim Institute, whose intellectual character perfectly suited the neighborhood, celebrated the similarities between French and Muslim civilizations, while the Mosque's Moroccan-style architecture guaranteed the authenticity of the practices that would be performed in the building. The deeply rooted French belief that Islam was a religion in which materiality mattered much more than in any other faith made the choice of embodying this vision of Islam in a mosque a logical one.

Yet the idea that Muslim practice was intrinsically physical and invaded all aspects of everyday life, confounding the public and private spheres, also implied that the metropolitan and colonial administrators who favored the Mosque's construction did not believe that it was possible for Muslims to become modern, French, secular subjects. The state that separated church and state in the law of 1905 insisted on identifying its colonial subjects and protégés as inevitably and only Muslim. As we see in the following section, the

\footnotetext{
23 Gary Wilder, The French Imperial Nation-State: Negritude and Colonial Humanism between the Two World Wars (Chicago: University of Chicago Press, 2005), 28.

24 Interestingly, one notable Muslim supporter of the Paris Mosque project was Cheikh al-Alawī, renowned for his defense of Islam in the face of French colonialism. The founder of the Țariqqa 'Alawiyya movement was not an official member of Si Kaddour's committee, yet his support for the Paris mosque led him to attend its inauguration. He believed the institution could serve the interest of Muslims living in the metropole.
} 
ambiguity at the heart of French Islam informed the policy and social assistance programs designed contemporaneously with the Mosque to cope with the North African immigrant population of Paris.

\section{Muslim Bodies in French Spaces}

The construction of the Paris Mosque and the Muslim Institute gave body to the vision of French Islam as imagined by its proponents, but in the late 1920s, the question of how government support for French Islam would affect the lives of the primarily male, working-class North African residents of the capital was unclear. Metropolitan and colonial proponents of French Islam did not recognize the Islam practiced by many of these men as "true" Islam; their religious observances were characterized as akin to paganism. The disregard of metropolitan and colonial officials, social scientists, and the Muslim leaders chosen by French authorities, for the Muslim practices of certain North African immigrants in the Paris region was essential to their defense of French Islam. Immigrants to France during this period sometimes linked their Muslim practices to nationalist activity; or to social solidarity and mutual aid societies; yet others focused on cultural activities. But from the very beginning of the articulation of French Islam by French politicians and the elite Muslim members of the Society of Habous the possibility of Islam's multiplicity, of different ways of being Muslim, was foreclosed.

Upon their arrival in Paris North African immigrants quickly learned that they would be counted, professionally oriented, and healed as Muslims rather than simply as immigrant workers. With the Mosque as the central site of Muslim authority, the national and local administrations created a city- and suburban-wide network of Muslim sites designed to structure the lives of North African immigrant workers. Sites like the Bureau de la rue Lecomte, at once a social assistance office and a surveillance center, or the Franco-Muslim Hospital in the northeastern suburb of Bobigny were part of a network of separate social assistance services centered on Muslim religious identity and created for North African immigrants. The foundations for the French policy of administering North African immigrants exclusively as Muslims were thus laid at the same time as the creation of the Mosque itself. The tension between the promise of openness embedded in the logic of French Islam and the restrictiveness of Parisian Muslim institutions symbolizes the paradox at its heart. Although all immigrant workers during this period were subject to different legal regimes than were French citizens, the programs designed for North African Muslims set them apart from other immigrants, even other colonial 
immigrant workers. The rationale for this segregation was corporeal: the French belief in the centrality of embodied practices in the lives of Muslims meant that the kinds of services that were designed to assist North African immigrants took for granted that Muslim bodies had different demands than non-Muslim ones. The Franco-Muslim Hospital is the example par excellence of the state's contradictory impulses: while the construction of this hospital effectively "protected" Parisian public hospitals from what were seen as disease-ridden North African male bodies, some of its proponents also sincerely believed that they were providing Muslims with the space to engage in Muslim practices safely and securely. This corporeal logic of the 1920s and 1930s, couched in the language of religious protection, continued to influence French Muslim policy throughout the twentieth century.

North African immigrants were thus administered separately from other foreigners (even though Algerians were in fact French nationals, if not French citizens), and more importantly, they were administered as religious subjects. On the one hand, the state could be commended for providing them with religious services that may otherwise have been unavailable to them since there simply was not a longstanding Muslim community capable of providing religious sites for new immigrants. Yet on the other hand, by requiring them to make use of separate Muslim services, the French state made it impossible for Muslim immigrants to be anything but Muslim. The Ministry of the Interior simultaneously helped finance the salary of an imam to serve Paris's North African population and created a complex network of techniques for policing those same people. In the years immediately following World War I, war-era "Muslim" organizations resurfaced in new forms, of which the more important was Service des Affaires Indigènes Nord-Africaines (The North African Native Affairs Service, or SAINA), created in 1928. The SAINA, controlled by the Préfecture of the Seine and the Préfecture of Paris, was directed exclusively at the capital's North African population. The cornerstone of this service was known as the Service de la rue Lecomte, or, as it was officially called, the North African Brigade (Brigade nord-africaine).

Rue Lecomte was, to a large extent, the result of one man's obsessive campaign to bring the lessons he had learned as a colonial official in Algeria to bear on the administration of North African immigrants in Paris. Pierre Godin, whom we met earlier, began his career in Algeria as a clerk and went on to become a police officer and eventually a sous-prefect. Godin believed that an understanding of the "native mentality" was essential to the proper management of the capital's North African populations, and indeed rue Lecomte was directed by a former official from the French administration in Algeria: Adolphe Gérolami, who had been chosen for his knowledge of the "Algerian 
Muslim."25 Although the Bureau de la rue Lecomte was described as a resource center for North African Muslim workers, it was primarily a site designed to monitor the movements and activities of the Maghrébin population in the city and suburbs. Godin, who was of course one of the Mosque's main proponents, explained in his report to the Paris City Council:

A recent and sensational crime - the murder of two poor women...by an Algerian Kabyle...has focused the anxious attention of public opinion on the invasion of France by foreign or colonial elements, especially North African emigrants. [Public opinion] is beginning to wonder if some prudent measures wouldn't be in order, to discipline, maybe even limit, this invasion. ... We do not know exactly how many Algerian or African natives [indigènes] there are in Paris. ... Algerian indigènes travel freely and thus it is very difficult to follow this errant work-force in its peregrinations. ${ }^{26}$

The Service de la rue Lecomte was designed to respond to this free-floating anxiety about the presence of these "timid men from the mountains" transformed into "urban workers" and living among the French. Godin minced no words about the service's dual purpose: to "monitor and aid" the city's North Africans. He presented it as a moral imperative, for "these 'primitives' are among us. These 'mountain dwellers,' these 'barbarians' heard civilization's call and are tasting the charms of the City. With them, old Africa opens itself up and comes to us. It is Islam, approaching."27 The equation of "old Africa" with "Islam" in this formulation is instructive. What is most important to note about rue Lecomte is the way its programs were structured around a conception of these workers as simultaneously Muslim and North African. For Godin and the other authorities involved in the management of North African immigrant populations, "Africa" arriving on France's doorstep was really the approach of Islam.

The rue Lecomte site was located in a former school building in the eastern part of the 17th arrondissement. Initially, it consisted only of a labor placement

25 Clifford Rosenberg, Policing Paris: The Origins of Modern Immigration Control between the Wars (Ithaca, NY: Cornell University Press, 2006), 155-157.

26 "Proposition tendant à créer à la Préfecture de Police une section d'affaires indigènes nord-africaines qui s'occupera de la situation matérielle et morale et de la police des indigènes nord-africains, resident ou de passage à Paris. Déposée par MM. Pierre Godin, Besombes, et Emile Massard, Conseillers Municipaux," Proposition no. 178, 20 December 1923. Conseil Municipal de Paris, Rapports et Documents 1923, Nos. 151-191.

Ibid. 
and information office for North African workers' use. North African immigrants to Paris were required to register their presence at the office and occasionally to renew their identity papers. Rue Lecomte employees also promised aid with locating jobs, translation, legal paperwork, the shipment of one's earnings to family in North Africa, and other services. The complex also featured a cafe, which, along with the other resources, was largely ignored by the city's Muslims, as Gérolami sadly reported to a colonial official visiting from Morocco. ${ }^{28}$ The following year, in 1926, the City Council inaugurated the dispensary, which provided basic care and minor surgery. Medical professionals concerned with public health noted with relief that the clinic also featured special services for those afflicted with tuberculosis and venereal diseases, which were thought to be endemic to North Africans. ${ }^{29}$ In 1927, an eighty-bed hostel, or foyer, also opened as part of the rue Lecomte site. Gérolami hoped to extend his and his institution's authority beyond the walls of the rue Lecomte complex and do a better job of winning the loyalty of the city's Muslim workers. Another foyer was built in the suburb of Gennevilliers, which featured a prayer room, "hammam and café," and dormitories, and the rue Lecomte's director hoped to see similar foyers develop all over the city and suburbs. Gérolami believed that his agency and other Parisian Muslim institutions needed to create deeper connections with the city's Muslim communities and that the best way to do this was through the creation of mutual aid societies, which would work through the idiom of Islam. He tried to launch a "fraternal association of... Muslims in Paris, a sort of mutual assistance society, whose first project would be the construction of the wall of the Muslim cemetery of Paris." ${ }^{30}$ Gérolami's Muslim mutual aid society, however, met with as little success as his café, for Muslims continued to rely on their own associations rather than pay a monthly membership fee to join rue Lecomte's association.

Managing North African immigrants thus revolved around two poles: social assistance and policing. The trio that oversaw Paris's "Muslim" institutions, Si Kaddour, Gérolami, and Godin, was implicated in providing the conditions for the "proper" observance of Muslim life cycle events, particularly illness and death. The Paris City Council and police were instrumental in managing endof-life issues for North Africans, religious or not, during this period. The links

28 Lt.-Col. Justinard, Rapport sur sa mission en France, novembre 1930, AMAEE K Afrique/ Questions Générales 1918-1940/32: Emploi de la main d'oeuvre indigène dans la Métropole, $1926-1928$.

29 See Max Hulman, "L’Hôpital Franco-Musulman de Paris et du département de la Seine," La Presse Médicale 74 (14 September 1935): 1443-1445.

$30 \quad$ Justinard, "Rapport." 
connecting the SAINA, the Mosque, and the Franco-Muslim Hospital in the eastern suburb of Bobigny were extremely close. ${ }^{31}$ The Interministerial Commission for Muslim Affaires (CIAM) was one of the agencies that influenced the decisions taken by this triumvirate. The cIAM pronounced itself in favor of standardized regulations concerning the burial of Muslims in the Paris region; the setting aside of plots in suburban graveyards, "where they can be buried according to their beliefs and rituals," in addition to the expensive Muslim area of the Père Lachaise public cemetery; the formation of an association to provide indigent Muslims with religious burials; and, finally, the creation of an Office of Muslim Beneficence. ${ }^{32}$ The question of Muslim cemeteries was thus considered at the same time that decisions about health care and foyers for North African workers were being made. The ciam dedicated a meeting early in 1931 to debating how and where a cemetery for Paris's Muslims could be created, with testimony from Si Kaddour, Pierre Godin, and Gérolami. The issue was raised when Si Kaddour addressed the Préfet de la Seine directly, asking that he support the establishment of such a site; he in turn consulted the minister of the interior about the legality of such an undertaking. Si Kaddour presented the issue as something that concerned Paris's Muslims "because of the religious character attached to Muslim funerals. If, in death, they find themselves far from Muslim lands, they attach an even greater value to having a cemetery reserved for members of their faith."33 The Préfet de la Seine's hesitation in the face of this request was based not only on his concerns about legality but also on fears that in giving $\mathrm{Si}$ Kaddour a positive response, "we would expose ourselves to reclamations in the same style from Protestants [and] Jews." ${ }^{34}$ Yet as $\mathrm{Si}$ Kaddour explained in person at the meeting, "As for the objections on legal grounds which have been put forward, they were also true for the Muslim Institute and the Paris Mosque, which were nevertheless created. Thus we need only follow an analogous procedure" to establish a cemetery. Godin's solution to this problem was to suggest that the Franco-Muslim Hospital contribute land for the creation of a Muslim burial ground, as hospitals serving particular populations could legally build cemeteries on their grounds. The ciAm accepted this compromise, and the burial ground was eventually constructed in Bobigny.

\footnotetext{
31 See Rosenberg, Policing Paris, 141.

32 Rapport de la CIAM, séance du 10 février 1927. ANOM 81F 834.

33 This letter, dated 9 December 1930, is cited by M. Augustin Bernard at the CIAM's meeting on 27 February 1931. See Procès-Verbal de la CIAM, 27 February 1931, Question 2: Demande de création d'un cimetière pour les Musulmans de Paris et de la region parisienne. ANOM 81F 834: Cimetières musulmans.

Ibid.
} 
In the debate over this issue, Si Kaddour was asked who would be buried in such a site. He responded that it would be primarily soldiers, "since the bodies of Muslim notables who die in Paris are usually repatriated to their country of origin by their families." Si Kaddour's assertion that a Muslim cemetery in Paris was of interest to Muslims the world over was an exaggeration, but it was certainly a point of interest to French diplomats and functionaries in the Muslim world who were concerned with the religious observances of the Muslim elite. As a French diplomat stationed in Cairo explained, although "the Orientals who travel to France belong to the fortunate classes who don't go to mosques," the Paris Mosque had still been used for the funerals of two Egyptians who, though not observant at all, still wanted a Muslim burial. He was strongly in favor of the creation of a Muslim cemetery, because although "a 'believer' can not pray, [and] he can be treated in a public hospital with no problem, ...he cannot face the idea of being buried right next to non-Muslims."35

While creating areas where Muslims could be buried according to the precepts of their religion was a priority for those making Muslim policy in the Paris region, their medical care was also a huge concern. As historian Clifford Rosenberg and others have shown, in the 1920 and 1930 s the French had great fears of venereal disease among the population of single North African men who arrived in France as laborers. Policies segregating this population to Muslim dispensaries and hospitals were based on these fears, yet were couched in the language of cultural sensitivity. The dispensary of the Mosque itself was formally placed under the control of the Office of Social Hygiene of the Préfecture de la Seine in 1928.

The real centerpiece of North African healthcare in Paris, however, was the Franco-Muslim Hospital of Bobigny, one of whose architects was none other than the Mosque's Maurice Mantout. The hospital was voted into existence by Paris's City Council on 11 July 1929 and came under the authority of the Département de la Seine in 1930. Its location was a source of great tension between the various Paris-area politicians involved in its creation, and it was eventually decided to construct it in the communist suburb of Bobigny as an attack on its leadership. ${ }^{36}$ Like the policing agencies, it was supposed to protect North African and French populations by isolating Muslim workers and providing them with separate services. During the period in which the hospital was conceived, constructed, and inaugurated, Paris's public health care system

\footnotetext{
35 Letter from Henri Gaillard to Aristide Briand, 21 March 1927. ANOM 81F 834.

36 See Neil MacMaster, "Imperial Façades: Muslim Institutions and Propaganda in Interwar Paris," in Promoting the Colonial Idea: Propaganda and Visions of Empire in France, ed. Tony Chafer and Amanda Sackur (New York: Palgrave, 2002).
} 
was in a disastrous state. The public hospitals served only Parisians whose incomes fell below a certain level, and its health care services were entirely free. Outdated and overpopulated, the city's hospitals were increasingly unable to cope with the demands of the city's population. In the face of these poor conditions, many local politicians objected to spending money on health care for immigrants, even though, statistically speaking, foreigners made up only a small percentage of the patients of the city hospitals overall.

The Franco-Muslim Hospital was designed to give North Africans access to a health care center big enough to cope with an increasingly large population (the Rue Lecomte and Mosque clinics had become too crowded). The arguments made in favor of this health care regime, which were echoed in the medical press, concerned not only anxieties about "African pathology which demands doctors and nurses with specialized education" but also social welfare concerns about a population that felt "unmoored, isolated" in French hospitals. North Africans treated in Paris's public hospitals "found none of the traditions and customs which are so important to them and to which they are so faithful. Everything, the staff, the other patients, was strange to them." ${ }^{37}$ The Franco-Muslim Hospital would allow them to feel at home again "during a time when, touched by illness, they are particularly sensitive." ${ }^{38}$ Although the hospital contained all of the most modern medical technologies, its façade was designed to signal its special North African character. The medical press was not insensitive to the display:

This monumental door, in pure mauresque style, produces a beautiful effect. ... It's very "local color," one finds oneself in a very evocative atmosphere. ... If one had to formulate a critique, it would be that it is too well done... a bit too luxurious for a clientele who, doubtless, will not appreciate it, nor understand it, nor take pleasure in it. ${ }^{39}$

Aside from its "Muslim" aesthetic, the daily administration of the hospital was structured around Muslim religious requirements. The statutes of the hospital decreed that a number of Arabic-speaking doctors, preferably those "familiar... with Muslim natives and their customs," would be recruited and that Arabicspeaking staff would receive bonuses. Freedom of religion would be respected within the hospital's walls, but "the Paris Mosque's imam or a Muslim clergyman designated by the Muslim Institute [would] have access to patients who

39 Hulman, “L'Hôpital Franco-Musulman de Paris," 1444. 
seek their assistance." Furthermore, the site would feature not only "a prayer room for the patients and Muslim personnel" but also a space for the "slaughter of animals according to Muslim ritual." 40 The hospital's Muslim personnel were given the day off on Muslim holidays, and during the month of Ramadan, patients' meals were served at sunset.

Although much care was taken to describe the hospital as a place designed to cater to Muslim religious needs, it was also a place to quarantine foreign bodies suspected of harboring dangerous diseases that might easily spread to French citizens. Or, as the president of the departmental council of the Seine explained at the hospital's inauguration, "We needed to protect, but also police, because undesirable individuals had been mixing with healthy elements."41 The full ambiguity of the French state's position lies in its attitude toward Muslim bodies: they were considered a danger to public health but were also taken seriously as having particular embodied religious practices that needed to be provided for in a hospital setting if patients were to have any hope of recovery. While those who celebrated the hospital's creation claimed that "the population truly appreciated" the special treatment the hospital afforded them, even if they could not fully understand the attention that went into its aesthetic planning, ${ }^{42}$ many North Africans did everything in their power to avoid receiving treatment at the Franco-Muslim Hospital. In 1937, for example, one third of admitted patients refused to be treated there. ${ }^{43}$ The special committee of the High Committee on the Mediterranean (Haut-Comité Méditerranéen, or НСM), a group of French experts on the Muslim world established under Léon Blum's Popular Front government, was disturbed to report that Muslims had to be forced to go to the Franco-Muslim Hospital against their will. The нсм's observers were surprised to find that "in spite of the excellence of the medical care, which incidentally demands a very significant budgetary contribution from the state, some North Africans prefer to be treated in other hospitals." ${ }^{44}$ A member of the Seine General Council went further in his observations of the missteps of the state's attempt to provide Muslims with appropriate health care. "I must say," Léon Mauvais explained, "that Arabs have come

40 Statuts de l'hôpital franco-musulman. Conseil général de la Seine, 9 July 1930.

41 Inaugural Speech, Augustin Beaud, Président du Conseil général de la Seine.

42 "L'Action charitable de la Ville de Paris et du département de la Seine," Le Plus Grand Paris 1 (February 1938).

43 See Rosenberg, Policing Paris.

44 Commission d'Études du HCM, "rapport conforme aux propositons de la sous-commission des lois sociales et assistance," 17 June 1937, AMAE K Afrique/1918-1940/Questions Générales. 
to complain that they have been forced to go to this Franco-Muslim hospital and that the Parisian hospitals did not want to admit them." Mauvais also noted that "some North Africans did not want to follow the special alimentary regime" used at the hospital "because they are now used to French customs, even [when it comes to food]."45 Immigrants' refusal to be segregated on the basis of religion suggests that they were fully aware that they were being denied access to the services available to everyone else, even as they were being offered special privileges. Their desire to be treated at French public hospitals may have stemmed in part from fears about the quality of care at the Franco-Muslim Hospital, but certain Muslims were also rejecting their involuntary assignation to the categories "Muslim," "Arab," and "North African." In other words, they were rejecting a regime that kept them outside of the boundaries of the French public sphere, supposedly for their own comfort, on the basis of their presumed religious identity.

\section{Conclusion}

It could be argued that in providing immigrant workers from majority Muslim countries with health care designed to respond to Muslim sensibilities or the means to celebrate major holidays at a mosque located in the center of the city, the French state was being more generous to its colonial subjects than it was to its metropolitan citizens (a charge often leveled against the founders of the Franco-Muslim Hospital, for example). Certain politicians working at the municipal and national levels truly believed that they were responding to a desperate need on the part of Muslim immigrant workers. Yet it is essential to remember that the discourse of providing Muslims with "special" medical or employment services masked the fact that they were kept in a parallel social universe, separated not only from the French but also from other immigrants. Having defined their vision of French Islam in the form of the Mosque, the next step for those involved in its administration was to use that "Islam" as the medium for all interactions with North African immigrants, thus reducing their multifaceted socio-cultural lives to a single element. The religious sentiments of working-class immigrants from the Maghrib were dismissed as unorthodox at best and illegitimate at worst.

The decision to structure social assistance programs for North African immigrants along Muslim lines set the pattern for the state's interaction with these 
communities. Rosenberg argues that by "treating North Africans so differently from other immigrants, by segregating them and subjecting them to an often brutal surveillance regime, republican authorities helped entrench what had been an unexceptional anti-'Arab' sentiment and reinforced a critical distinction between nationality and citizenship." ${ }^{\prime 6}$ While not disagreeing with this conclusion, I would suggest instead that the separate regime designed for North African immigrants, particularly in the case of Algerians who were in fact French nationals, was more significant in that it legitimized segregation on religious grounds in the name of cultural sensitivity. The local, national, and colonial politicians involved in the creation of the mosque, surveillance and medical apparatus that policed the capital's North Africans acted out of complex motives; some of them sincerely believed that they were providing their colonial workers with services they wanted. Judging their motives, however, is less important than recognizing the fact that French politicians believed Islam's embodied demands to be such that Muslims required separate hostels and hospitals and could not be assimilated into the larger immigrant population, let alone the French population. Thus in writing the long history of Islam's presence in metropolitan modern France, it is crucial to recognize the importance of the collaboration between the French state and $\mathrm{Si}$ Kaddour. While their strategic use of French Islam and its incarnation in these three institutions was contested by many North African immigrants, it nevertheless indelibly shaped the state's relationship with Muslims in France for the rest of the century.

\section{Bibliography}

\section{Archival Sources}

$\mathrm{AMAE}=$ Archives du Ministère des Affaires étrangères et européennes Afrique. $\mathrm{AN}=$ Archives nationales. ANOM $=$ Archives nationales d'outre-mer. APP $=$ Archives de la Préfecture de Police. SHAT $=$ Société historique de l'armée de terre.

\section{Primary Sources}

Bourdarie, Paul. "L'Institut Musulman et la Mosquée de Paris." La Revue Indigène (October-November 1919).

\footnotetext{
$46 \quad$ Rosenberg, Policing Paris, 198.
} 
Buchet, Georges. “La Mosquée de Paris." En Terre d'Islam 34 (1930): 28-32.

Descamps, Henri. L'Architecture moderne au Maroc. Paris: Librairie de la Construction moderne, 1931.

Goissaud, Antony. "L'Institut musulman et la Mosquée de Paris." La Construction moderne 3 (2 November 1924): 50-55.

Hulman, Max. “L’Hôpital Franco-Musulman de Paris et du département de la Seine." $L a$ Presse Médicale 74 (14 September 1935): 1443-1445.

L'Illustration. "Un décor d'Orient sous le Ciel de Paris." 26 November 1926.

Justinard, Pierre. "La Mosquée de Paris." MA thesis, Ecole nationale de la France d'outre-mer, 1944.

Madras, Didier and Boris Maslow. Fès, Capitale artistique de l'Islam. Casablanca: Editions Paul Bory, 1948.

Le Plus Grand Paris. "L'Action charitable de la Ville de Paris et du département de la Seine." 1938.

Revue Médico-Sociale. "L’Hôpital Franco-Musulman.” (1935): 134-135.

Weiss, René. Récéption à l'Hôtel de Ville de Sa Majesté Moulay Youssuf, Sultan du Maroc, Inauguration de l'Institut Musulman et de la Mosquée de Paris. Paris: Imprimerie Nationale, 1927.

\section{Secondary Sources}

MacMaster, Neil. "Imperial Façades: Muslim Institutions and Propaganda in Interwar Paris." In Promoting the Colonial Idea: Propaganda and Visions of Empire in France, ed. Tony Chafer and Amanda Sackur. New York: Palgrave, 2002.

Rosenberg, Clifford. Policing Paris: The Origins of Modern Immigration Control between the Wars. Ithaca, NY: Cornell University Press, 2006.

Sherman, Daniel. The Construction of Memory in Interwar France. Chicago: University of Chicago Press, 1999.

Wilder, Gary. The French Imperial Nation-State: Negritude and Colonial Humanism between the Two World Wars. Chicago: University of Chicago Press, 2005.

Wright, Gwendolyn. The Politics of Design in French Colonial Urbanism. Chicago: University of Chicago Press, 1991. 


\title{
Indonesian Islam in Interwar Europe: Muslim Organizations in the Netherlands and Beyond
}

\author{
Klaas Stutje \\ Introduction
}

Depending on the one's interpretation, Muslim life during the interwar period in the Netherlands can either be characterized as "Indonesian," "Dutch" or "European." Although Muslims in the Netherlands looked to the heartland of Islam for religious guidance, it was primarily their immigrant Indonesian status and their socioeconomic position in the Netherlands that determined the character of Muslim life there. The number of Muslim residents in the Netherlands before World War II was relatively low compared to the large Muslim populations in other western European colonial centers. And although they succeeded in building organizations and infrastructures of their own, the absence of large-scale postcolonial Muslim migration to the Dutch metropole, and the fact that the first official mosque was only established in 1955, has meant that research on Muslim life in the Netherlands has predominantly focused on postwar migrant workers from Morocco and Turkey who arrived during the 1960 s and after. Indonesians in the Netherlands in the pre World War II period have rarely been taken into account. ${ }^{1}$

In the coming pages, I aim to write the Dutch chapter of the history of Islam in interwar Europe by focusing on Indonesian Muslim groups in the Netherlands before World War II. This field of research has remained understudied in two ways. First, the Netherlands has remained largely beyond the scope of recent publications on the presence of Islam in interwar Europe, despite the fact that

1 Harry A. Poeze, In het Land van de Overheerser, I: Indonesiërs in Nederland 1600-1950 (Dordrecht: Foris Publications Holland, 1986). Cf. Nico Landman, Van Mat tot Minaret: de Institutionalisering van de Islam in Nederland (Amsterdam: vU Uitgeverij, 1992): 20-21; W.A.R. Shadid and P.S. van Koningsveld, Islam in Nederland en België: Religieuze Institutionalisering in Twee Landen met een Gemeenschappelijke Voorgeschiedenis (Leuven/ Paris/Dudley, MA: Peeters, 2008), 22. 
it had a considerable Muslim population under its imperial rule. ${ }^{2}$ Second, in the context of studies on the Dutch colonial past, research on Indonesian migration to the Netherlands has remained limited to political activities, for example, of the well-known Indonesian students association Perhimpoenan Indonesia. ${ }^{3}$ The Muslim identity of most of the Indonesian students, and of the Indonesian migrant community as a whole was not addressed. In 1967, the American anthropologist Joan Schutzman Wider was the first to devote a few pages on Perkoempoelan Islam - the only Islamic organization in the Netherlands before World War II - in an unpublished dissertation on postwar Indonesian domestic workers in the Netherlands; this work was followed in 1986 by a brief account by the Dutch historian Harry Poeze. ${ }^{4}$ It was only in 2012 that the Leiden historian Umar Ryad published a comprehensive article on Muslim life in the Netherlands; in it he focuses on the chief Muslim organizer and convert Mohammad Ali van Beetem and his role in the Indonesian community in the Netherlands. ${ }^{5}$ Ryad's article touches upon most of the organizational aspects of Muslim life in the decades before the war, but usually from the perspective of its central figure Van Beetem.

This chapter seeks to position Perkoempoelan Islam and its members more clearly within the landscape of the various Indonesian and other migrant communities in the Netherlands, and subsequently among the 'colonial' Muslim communities of Europe as well. This leads to a better understanding of the functions of Perkoempoelan Islam, and of its loyalist stance vis-à-vis the Dutch

2 Cf. Nathalie Clayer and Eric Germain, eds. Islam in Inter-War Europe (London: Hurst \& Company, 2008).

3 John Ingleson, Perhimpunan Indonesia and the Indonesian Nationalist Movement, 1923-1928 (Melbourne: Monash University, 1975); Harsja W. Bachtiar, "The Development of a Common National Consciousness among Students from the Indonesian Archipelago in the Netherlands," Majalah Ilmu-Ilmu Sastra Indonesia 6 (1976): 31-44; Poeze, In het Land van de Overheerser.

4 Joan Schutzman Wider, "Indonesian Women in The Hague: Colonial Immigrants in the Metropolis" (PhD diss., New York University, 1967), 82-86; Poeze, In het Land van de Overheerser, 288-290, 316-318. Cf. Annemarie Cottaar, Ik had een Neef in Den Haag: Nieuwkomers in de Twintigste Eeuw (Zwolle: Waanders, 1998), 81-82; René Karels, Mijn Aardse Leven Vol Moeite en Strijd:Raden Mas Noto Soeroto, Javaan, Dichter, Politicus 1888-1951 (Leiden: KITLV Uitgeverij, 2010), 93, 96-97, 174-175.

5 Umar Ryad, "Among the Believers in the Land of the Colonizer: Mohammed Ali van Beetem's Role Among the Indonesian Community in the Netherlands in the Interwar Period," Journal of Religion in Europe 5 (2012): 273-310; Umar Ryad, "Te Gast in Den Haag: Discussies Moskeebouw in Nederland vóór de Tweede Wereldoorlog," Tijdschrift voor Religie, Recht en Beleid 4 (2013): 59-78. 
government. It also helps to accurately assess its religious engagements with Muslim organizers abroad.

Three issues in particular are addressed in this chapter. First, I describe the various Indonesian communities in the Netherlands and their infrastructures, with special attention to the workers in Perkoempoelan Islam. Second, I examine the attitude of Dutch authorities towards Muslim organizations. This also determined the ability of an organization such as Perkoempoelan Islam to negotiate on behalf of Indonesian Muslims. In a third section, I evaluate the various international contacts of Indonesian Muslims with networks in Europe. Here, I not only assess primarily Islamic engagements, but also include contacts with anticolonial networks and with Cairo. These events were part of the Islamic landscape of Dutch Indonesian Muslims as well.

In writing the history of Islam in the Netherlands it is useful to distinguish between the practicing of faith by individuals, and the organization of Muslims as a group. With regards to the former, it is remarkable that the various autobiographies and personal accounts by Indonesians in the Netherlands, who often became dignitaries in the period of independence, are strictly confined to the political sphere and offer scant information on their practices and beliefs during their Dutch years. Nevertheless, I assume that throughout the period of Indonesian migration to Europe, Muslims to some extent continued to observe the religious duties of Islam on their own initiative and in the private sphere. ${ }^{6}$ It is implausible to suggest that the Indonesians only became more 'religious' or devout once Perkoempoelan Islam was established in May 1932. At the organizational level, however, Muslim life did find its first embodiment with the establishment of Perkoempoelan Islam. ${ }^{7}$

\section{Indonesian Communities in the Netherlands}

The Dutch Indonesian community can be subdivided into three groups. The first group consisted of Indonesian students who arrived from the last decades of the nineteenth century onwards, and with greater numbers after World War I. The cohorts of students before the war were predominantly of Javanese aristocratic descent; this was a class that was dependent on the Dutch colonial administration for its wealth and social position. Unable to maintain

6 Cf. Schutzman Wider, "Indonesian Women in The Hague," 80-86.

7 Harry A. Poeze, Politiek-Politioneele Overzichten van Nederlandsch-Indië: Deel IV (Dordrecht: Foris Publications Holland, 1994), lxxviii. 
the traditional way of life, many lower aristocratic families chose to adapt to the new power system and sent their sons to Europe for some years of higher education. ${ }^{8}$ After World War I, with the native rubber industry booming, the social make-up of the student community in the Netherlands changed somewhat and wealthy merchant families started to send their children overseas as well. These Indonesian students lived predominantly in the university cities of Leiden and Delft, although all university towns in the Netherlands attracted students from the Dutch East Indies. Their number can be estimated from a few dozen in the first two decades, to up to two hundred people in the peak years before the Great Depression. ${ }^{9}$

A much larger group of Indonesian shopkeepers, restaurant-owners, and their personnel began to arrive in Dutch urban centers from 1900 onwards. Together with Indonesian domestic workers (baboes or iboes) that traveled along with their Dutch employers on leave, they formed the largest group of Indonesians in the Netherlands. A considerable Indonesian community emerged in The Hague, alongside Dutch families with a colonial background (verlofgangers) temporarily residing in the Dutch metropole. ${ }^{10}$ In general, the Indonesian workers and retailers in The Hague were from a less wealthy background than the students residing in Leiden and Delft. This class of people has received less attention from scholars, probably because they left fewer written sources than their student compatriots, and also because their political behavior was less outspoken. Nonetheless, their shops and restaurants today are the most visible reminders of the Dutch-Indonesian communities from before the war.

A third considerable group of Indonesians in the Netherlands consisted of dockers, sailors, and stewards on cargo and passenger ships that commuted to and from the colony. Of this last group little is known. Most of them were in the Netherlands only temporarily, and while on leave they usually stayed on their ships or in boarding houses in the harbor districts of Rotterdam and Amsterdam. There was a lively black market of colonial and European wares and clandestine literature, but despite the targeted attempts of communists to bring the transient sailors into contact with Dutch and Indonesian-Dutch political

8 H.A. Sutherland, The Making of a Bureaucratic Elite: the Colonial Transformation of the Javanese Priyayi (Singapore: Heinemann Educational Books, 1979), 144.

$9 \quad$ Poeze, In het Land van de Overheerser.

10 Cottaar, Ik had een Neef in Den Haag, 72-75; Karels, Mijn Aardse Leven Vol Moeite en Strijd, 170 . 
organizations, there was only incidental political or organizational cooperation with other Indonesian communities. ${ }^{11}$

\section{Indonesian Organizations in the Netherlands}

As stated above, most studies on Dutch Indonesian organizational infrastructure have focused on the organizational history of the first group. They describe how, in 1908, students established an 'Indies' association (the Indische Vereeniging) to provide an environment where they could socialize, where newcomers could find welcoming support, and where contact with the motherland could be maintained. This organization was closely connected to the general academic life in Leiden and other university towns. Many of the members of the Indische Vereeniging were also members of elite Dutch student societies; the so-called corpora or fraternities. With regard to colonial policy, most students initially adhered to the associationist liberal school of the 'ethici,' which also found strong support among prominent Leiden professors. ${ }^{12}$ These students advocated moderate political reforms in the colony, with an emphasis on modernization and development. Nonetheless, they believed these reforms should take place under Dutch guidance, and hence the 'ethici' remained loyal to Dutch rule over the colony.

In 1923, a nationalistic student organization broke away from the loyalist majority and started to agitate against the Dutch colonial administration. This organization, Perhimpoenan Indonesia ('Indonesian Association'), caused much upheaval in the Dutch media and governmental circles. Its leaders, such as Hatta, Sjahrir, and Sastroamidjojo, who later became prominent political figures in Indonesia, were constantly in the spotlights of security forces and the media, and consequently of scholars as well. ${ }^{13}$

11 Schutzman Wider, "Indonesian Women in The Hague," 191-197; Cottaar, Ik had een Neef in Den Haag, 79 .

12 Among Dutch imperial historians the 'ethical' tradition refers to a set of reformist social liberal ideas on colonial development that was current in the first decades of the twentieth century among colonial ideologues and politicians. As such, it does not bear a normative connotation. For a study on the manifold character of the ethical political tradition, see Elsbeth Locher-Scholten, Ethiek in fragmenten. Vijf studies over koloniaal denken en doen van Nederlanders in de Indonesische Archipel 1877-1942 (Utrecht: Hes Publishers, 1981), 176-208.

Ingleson, Perhimpunan Indonesia and the Indonesian Nationalist Movement, 34. 
Social formations among the other permanent Indonesian community in the Netherlands - the retailers, the cooks, and the domestic workers in the urban centers of Holland-attracted much less attention. They were less inclined to pursue radical political aims, they were oriented on self-help and mutual aid, and were not integrated into the higher social, political or academic strata of Dutch society. As such they had a truly subaltern character, both with regard to their highly vulnerable and somewhat invisible social position, and in terms of their subsequently poor historiographical representation by historians and social scientists. It is precisely among these classes that Perkoempoelan Islam found its origins. The organization was mainly active in The Hague; it began in 1932 with sixty members but gradually grew to roughly 300 members around 1940 . According to the articles of the association, Perkoempoelan aimed to facilitate the observance of the commandments of Islam, to promote a feeling of mutual brotherhood among its members, and to maintain relations with members of other religions in the Netherlands. Its most immediate ambition was to establish a Muslim cemetery and a community building annex mosque in The Hague, where most Muslims lived. ${ }^{14}$

\section{Characterizing the Perkoempoelan Islam in the Netherlands}

In characterizing Perkoempoelan Islam and its role in the Indonesian community three aspects should be mentioned: the socio-political views of its most prominent members, the crucial role of ordinary members in organizing The Hague's Muslims, and the social and representative functions of this religious association.

With regard to the first issue, one of the initiators of Perkoempoelan Islam and its most conspicuous member, Mohammed Ali van Beetem, is rather atypical. Umar Ryad has already devoted considerable attention to this Dutch convert, born Jean Louis Charles van Beetem, he converted to Islam in a public ceremony in $1931 .{ }^{15}$ His political character was much more pronounced than the views of ordinary Indonesian workers. Before this retired marine officer began to lobby for the establishment of a mosque and a Muslim organization

14 "Indië in Nederland," De Indische courant (29 February 1932); Ryad, "Among the Believers," 290-291.

15 Ryad, "Among the Believers"; Poeze, In het Land van de Overheerser, 196, 288-290. On Van Beetem, Oedaya, and Noto Soeroto: Karels, Mijn Aardse Leven Vol Moeite en Strijd, 93, 96-97. 
in the Netherlands at the end of the 1920s, he engaged in various national relief campaigns for the Dutch East Indies, and contributed to the conservative colonial journal Oedaya.

In 1929 he stood in the Dutch parliamentary elections for a short-lived ultranationalist party, the Bond van Nationalisten. In public meetings Van Beetem advocated a tough Dutch nationalist policy, fulminating against socialism and social-democracy, and loudly opposing the often heard Indonesian secessionist slogan "Indië los van Holland, nu!" ("The Indies apart from Holland, now!"). ${ }^{16}$ This brought Van Beetem into conflict with the nationalistic students in Perhimpoenan Indonesia, who called him a fascist and refused further cooperation. Concurrently, however, Van Beetem started to campaign for the establishment of a mosque in The Hague. ${ }^{17}$

For Van Beetem, this combination of ideas was less contradictory than it might seem. The promotion of Muslim interests by Van Beetem was not part of an anticolonial agenda, as was the case with Permi (Persatoean Muslimin Indonesia) and other contemporary Islamist organizations in the Dutch East Indies. Rather, the idea that the Dutch Muslim community was in need of its own societal institutions must be interpreted as part of a conservative agenda of 'sphere sovereignty.' In the Dutch context, this concept found strong support among Reformed Christian and Catholic leaders from the end of the nineteenth century onwards; they were defending their socio-religious sphere of influence against other denominations and against the state. This belief in political and socio-religious sovereignty, often referred to as 'pillarization,' was dominant throughout the first half of the twentieth century, and was also applied to the accommodation of foreign refugees and migrants, such as Catholic miners from Slovenia and Poland. Non-Christian migrant groups, such as Jewish refugees from Eastern Europe and Russia, Chinese workers in the Dutch harbors, and Indonesian workers in The Hague, had to build their own supportive social structures, and it was to this end that Mohammed Ali van Beetem worked. ${ }^{18}$

16 "Verbond van Nationalisten," Nieuwsblad van het Noorden (10 March 1928); "Verbond van Nationalisten," Het Vaderland (26 March 1929); "Verkiezingen Tweede Kamer, de candidaatstelling," Het Vaderland (21 May 1929); Mohammad Hatta, "De lezing van Stokvis voor de 'Perhimpoenan Indonesia," De Socialist (8 June 1929); "Perhimpoenan Indonesia; de ervaringen van Stokvis," De Sumatra Post (8 July 1929).

17 J.L.Ch. van Beetem, "Een Moskee in Den Haag," Het Vaderland (15 June 1929).

18 Jan Lucassen and Leo Lucassen, Winnaars en Verliezers: Een Nuchtere Balans van Vijfhonderd Jaar Immigratie (Amsterdam: Uitgeverij Bert Bakker, 2012), 174-185. 


\section{Rank and File}

Less politically outspoken than Mohammed Ali van Beetem, but more representative of the rank and file of Perkoempoelan Islam, were the other founding members 'Baas' N. Oesim and Saiman (alias Pak Bouman). The former, who was secretary for Perkoempoelan Islam, and its driving force after the death of Van Beetem in 1938, worked as a cook in a restaurant, the Soekoe Manah on Groot Hertoginnelaan in The Hague. The latter, Saiman, opened an Indonesian restaurant in 1922 together with his wife. More than once, Saiman proved central to the Indonesian workers community. His restaurant, Senang Atie, was located just across from Van Beetem's house, at Balistraat 70, and with traditional food at low prices it was a popular meeting place for Indonesian workers. The preparatory meetings for the establishment of Perkoempoelan Islam were held in Saiman's restaurant; ceremonial slametan-dinners and lebaranfestivities, to celebrate the end of Ramadan, were organized in his house at Obrechtstraat 117 (see Figure 6.1). ${ }^{19}$

Although Saiman and Oesim were very active in organizing the Muslim community in The Hague, they did not engage in overt politics. Whereas Van Beetem was active in various conservative organizations and campaigns, the names of Oesim and Saiman were nowhere to be found in other Indonesian political organizations or official festivities. In this respect, it is important to remember that most of the Indonesian workers were illiterate and did not speak Dutch very well. ${ }^{20}$

At least until the establishment of a community building, the religious and social life of Perkoempoelan Islam was centered around individuals and their respective homes. Van Beetem, Saiman, and Oesim were very energetic in attracting new members and in realizing a basic Islamic infrastructure. In $193^{2}$ they negotiated with the local government to designate an Islamic section in the public cemetery of The Hague, and in 1935 they established a langgar at Hugo de Grootstraat 31 in that same city. ${ }^{21}$ Van Beetem's house was open to all

19 "Islamieten Vereeniging," Algemeen Handelsblad (9 October 1932); "Brieven uit het Moederland," Het Nieuws van den Dag voor Nederlandsch-Indië (28 October 1932); Poeze, In het Land van de Overheerser, 238.

20 Schutzman Wider, "Indonesian Women in The Hague," 170, 217, 222.

21 "Islamietische Begraafplaats," Het Vaderland (24 December 1932); "Perkoempoelan Islam," Het Vaderland (4 March 1935); Schutzman Wider, "Indonesian Women in The Hague," 84. In the southeast Asian context a langgar is a mosque, but smaller, privately owned and usually attached to or part of a house, see Clifford Geertz, The Religion of Java (Chicago: University of Chicago Press, 1976), 181. 
Indonesian Muslims as a taman persaudaraan, 'house of brothers,' and meetings often took place in Saiman's restaurant.

Other members supported the association as well. The apartments of Kassanna and Mar Kasim at Obrechtsstraat 431 in The Hague, the boarding house Persinggahan at Van Boetzelaerlaan 2, and café De Groothertogin at Groot Hertoginnelaan in the same city were also prominent locations. ${ }^{22} \mathrm{~A}$ special communal function was performed by Indonesian iboes-the female domestic workers and nannies that worked with Dutch colonial families on leave. Though they remained completely absent from official accounts, they played an important role in preparing the ceremonial and religious slametanmeals. On special occasions, such as funerals, weddings or with the lebaran feast that marks the end of Ramadan, they came together to prepare meals, thereby facilitating the religious ceremonies and enhancing social cohesion among the Indonesian workers community as a whole. ${ }^{23}$

Socially, Perkoempoelan Islam, the only Muslim association in the Netherlands, functioned primarily as a communal organization in which workers found a welcoming environment. Politically, its character was mainly determined by Van Beetem's conservative views, but these were perhaps more visible from the outside than within the workers community itself. It may have prevented, however, cooperation between the organization and the politically outspoken anticolonial students in Perhimpoenan Indonesia. Although the latter organization was in favor of inter-communal, inter-religious, and interregional unity and solidarity, they also required, as a fundamental precondition for cooperation, an anticolonial and non-cooperative stance towards the Dutch state.

Conversely, Perhimpoenan Indonesia was not a serious partner for the Indonesian workers in Perkoempoelan Islam. Not only was the student association inter-religious, and therefore non-Islamic because of its multi-religious membership, but more importantly, Perhimpoenan Indonesia was deemed too elitist, and insensitive to the immediate problems of their poorer compatriots. As Schutzman Wider indicates in her examination of Dutch Indonesian workers after World War II, differences in social background often prevented structural cooperation between the two groups. ${ }^{24}$

\footnotetext{
22 "Viering van het Indisch Nieuwjaar," Het Vaderland (28 January 1933); Landman, Van Mat tot Minaret, 21.

23 Schutzman Wider, "Indonesian Women in The Hague," 86-91, 199-200.

24 Ibid., 214.
} 


\section{Social and Representative Functions and the Negotiation of Space}

In fact, in the Indonesian organizational landscape, Perkoempoelan Islam was the only body that could represent Indonesian workers in socio-economic matters vis-à-vis the local or national government. Other organizations in the Netherlands, such as Perhimpoenan Indonesia and Roekoen Peladjar Indonesia (established in 1936) were predominantly focused on students. Moreover, other organizations either explicitly refrained from political action and narrowed their activities to the cultural sphere, as was the case with Roekoen Peladjar Indonesia and the Indo-Chinese association Chung Hwa Hui, or they consciously exercised 'big-politics' with regard to the situation in the Dutch East Indies, as was the case with Perhimpoenan Indonesia. Mutual aid or practical representation were not among the latter's fields of interests.

This aid was, however, urgently required as the Great Depression devastated the world in the 1930s. The Indonesian workers were particularly vulnerable in the disastrous economic situation. The Dutch East Indies were hard hit by the depression, and one-sixth of the large European and Eurasian population were unemployed during this period. ${ }^{25} \mathrm{~A}$ considerable number chose to migrate to the motherland, but were unable to find employment there either. ${ }^{26}$ Indonesian domestic workers and cooks that had followed their employers, the Indies families, to The Hague were dismissed. Indonesian workers had an additional problem: they were not eligible for unemployment benefits, as they had been employed unofficially, nor were they eligible for local welfare, which required that one be registered in a municipality for more than a year. These unemployed workers faced the additional misfortune of being too poverty-stricken to afford return tickets to Indonesia. Perkoempoelan Islam stepped into this void of socio-economic despair, both in terms of direct aid and by protecting their interests at the official level. ${ }^{27}$

In Joan Schutzman Wider's interviews with domestic workers in The Hague, she describes how Mohammed Ali van Beetem took direct relief seriously: "When I was sick, he took me to the hospital"; "If a family was not good, he spoke to them or found us another family"; "Once he brought me some coal, when I was not well enough to work." ${ }^{28}$ Van Beetem was also instrumental in

25 John Ingleson, "Fear of the Kampung, Fear of Unrest: Urban Unemployment and Colonial Policy in 1930s Java," Modern Asian Studies 46 (2012), 1639-1643.

26 "Werklooze Suikergeëmployeerden in Nederland; twee duizend Indische werkloozen?" De Indische courant (4 December 1934).

27 Poeze, Politiek-Politioneele Overzichten, Deel III, 423; Ibid., Deel IV, lxxviii.

28 Schutzman Wider, "Indonesian Women in The Hague," 71. 
working for the Indonesian workers at the official level. In June 1933 the association, according to its loyalist views, sent a letter to the Dutch Queen to inform her of the dire situation of Indonesian domestic workers. In this letter, Van Beetem argued that Indies families should be obligated to maintain their servants, and that with a subsidy, Perkoempoelan could ease the most urgent problems. Furthermore, Van Beetem started negotiations with the municipal social service of The Hague, the 'Dienst Maatschappelijk Hulpbetoon' which provided unemployment benefits; he urged them to make an exception to the one-year residency rule for unemployed Indonesians. ${ }^{29}$ Finally, when the langgar opened its doors, a job mediation office for Indonesian servants was established as well. ${ }^{30}$

\section{Loyal but Vulnerable}

Compared to the other Indonesian organizations, the Muslim association had to maintain a balance between loyalty to the state and criticism of its policies. For the nationalists in Perhimpoenan Indonesia it was clear that there was no space for negotiation with the Dutch authorities. And even if there was, they adhered to the position of non-cooperation. At the other end, the moderate 'ethici' were deeply involved in the upper strata of academic life and society, and their journals and associations generally adopted an apolitical stance. The authorities initially approached Perkoempoelan Islam sympathetically, especially with regard to the cemetery and the one-year residency rule. ${ }^{31}$ After all, Perkoempoelan was not a political organization and was outspoken in expressing its loyalty to the queen. The Dutch central intelligence agency even praised the work of Van Beetem because he kept his followers from taking "revolutionary paths." ${ }^{32}$

Nonetheless, despite the loyalist views of Van Beetem, the local and national authorities ultimately adopted an uncooperative attitude towards Perkoempoelan Islam once it started to pursue social aims. For reasons that are

29 "De behandeling van Nederlandsch-Indiers," Algemeen Handelsblad (22 June 1933); "Perkoempoelan Islam," Het Vaderland (29 October 1933); “De Islam, lezing R.A.A. Wiranatakoesoema," De Indische courant (14 November 1933).

$30 \quad$ "Perkoempoelan Islam," Het Vaderland (4 March 1935).

31 "Perkoempoelan Islam, afscheid Van Beetem," Het Vaderland (28 December 1933).

32 "Brieven uit het Moederland," Het Nieuws van den Dag voor Nederlandsch-Indië (28 October 1932); "Deelneming der Perkoempoelan Islam," Het Vaderland (29 March 1934); De Nederlandse Bank archive. 
unclear, the social service suspended payments to Indonesian workers in 1935, and other requests of Perkoempoelan fell on deaf ears. The authorities seemed to be more interested in solving the problem by repatriating the 'foreign' workers, than in mitigating their needs. ${ }^{33}$

In this respect, there are clear similarities with the governmental approach towards other migrant communities in the 1930s, such as the Chinese workers communities of Rotterdam and Amsterdam. The local and national Dutch authorities tried to bring an end to the problem of "the Chinese and other Asian vermin" - as an official at the Ministry of Justice addressed the severely hit community - with a combination of administrative restrictions on immigration, and aid deprivation for the destitute Chinese sailors. ${ }^{34}$ Over ten years' time, the once bustling Chinatowns in Rotterdam and Amsterdam, once home to around three thousand souls, were reduced to around two hundred persons (in 1939). ${ }^{35}$ Although the Netherlands never knew fascist or national-socialist movements of the size of those in Germany and other European countries, authoritarian nationalist governance, xenophobic ideas, and thinking in terms of final solutions were certainly on the rise. Officially, the Indonesians were subjects of the Crown, but that fact did not protect the workers' communities of The Hague; indeed they were still faced with these sentiments and policies. In April 1935, Mohammed Ali van Beetem resigned from his post as secretary of Perkoempoelan Islam as he felt that his many attempts to address the various authorities met no results. ${ }^{36}$

\section{Indonesian, Dutch or European Muslims?}

As indicated above, Perkoempoelan Islam was the only official Muslim association in the Netherlands; its objective was to facilitate the observance of the commandments of Islam. Nonetheless, more significant than its religious character were its social functions as a communal self-help organization for its

33 "De Islam, lezing R.A.A. Wiranatakoesoema," De Indische courant (14 November 1933); "Stopzetting van steun aan Inlanders," Algemeen Handelsblad (10 March 1935); "Indische en Inheemsche werkloozen," De Indische courant (22 June 1935).

Henk J.J. Wubben, Chineezen en Ander Aziatisch Ongedierte: Lotgevallen van Chinese Immigranten in Nederland 1911-1941 (Zutphen:Walburg Pers, 1986); Lucassen and Lucassen, Winnaars en Verliezers, 179-180.

36 "Perkoempoelan Islam," Het Vaderland (15 April 1935); "Indiërs in Nederland: De invloed van extreme elementen, Perkoempoelan Islam," De Indische Courant (10 May 1935). 
members, and as a body for official representation vis-à-vis authorities and employers. In essence Perkoempoelan Islam - of which no non-Muslim Dutchman was member-was a "Dutch" organization in that it was firmly rooted in Dutch society. The Dutch environment, rather than the Islamic world, determined to a large extent its shape and functions. Not surprisingly, Mohammed Ali Van Beetem, who stood with one foot in the Muslim community and with the other in Dutch society, played an important role in representing the Indonesian workers in The Hague, despite being very different from the rank and file of the community.

The "Dutch" and communal character of Perkoempoelan Islam raises the question: to what extent was the organization was connected to the larger Muslim world at all? Were there any attempts to reach out to other Muslim communities, for example, in other countries of western Europe? In France more than 300,000 Muslim workers from the colonized world supplemented the crippled French workforce after World War I. In Britain there were several hundred British converts, and between 10,000 and 20,000 Muslims from British India, Malaysia, and the Arab Peninsula. In Germany, Italy, and Spain thousands of Muslims filled the ranks of the armies, the universities, and the factories. ${ }^{37}$

In the case of Perkoempoelan Islam there is scant archival information on its connections with other groups in Europe. There appear to be two reasons for this lack of information. First and significantly, Perkoempoelan Islam was absent on the radar of Dutch authorities, and hence it remained largely undocumented. Anticolonial Islamist, nationalist or communist organizations were much more distressing to the authorities than the loyalist Perkoempoelan Islam. Neither the documents filed in the archives of the Dutch Ministry of Colonies, nor the monthly reports on political and social action in the Netherlands and the colonies issued by the Dutch East Indies ProcuratorGeneral mention Perkoempoelan Islam. The association is mentioned only twice, and these are references to its loyal and strictly legal approach. ${ }^{38}$ The most informative sources about religious activities are contemporary newspaper articles that do not give information on the organization's involvements with Dutch Indonesian Muslims abroad.

Second, the scarcity of information on international Muslim networks in the Netherlands may also be due to the fact that the domestic workers, cooks, and shopkeepers of Perkoempoelan Islam lacked the international outlook of

37 Clayer and Germain, Islam in Inter-War Europe, 11-15.

38 Poeze, Politiek-Politioneele Overzichten, Deel III, 423; Ibid., Deel IV, 392. 
the Senegalese dockers of Marseille, the Yemeni sailors of Cardiff, or for that matter the Indonesian students of Perhimpoenan Indonesia. The nature of their professions did not stimulate international contacts. Moreover, the raison d'être of their organization was less dependent on propaganda abroad or solidarity from foreign organizations. In contrast to the nationalist Indonesian students in Perhimpoenan Indonesia who, after 1923, consciously established contacts with other anticolonial nationalists in Europe, Perkoempoelan Islam was more concerned with the needs and challenges of its own community in The Hague, than with networking abroad. ${ }^{39}$

\section{Muslim Networks Abroad}

Nonetheless, despite the fragmented source materials, we can distinguish an international side of Islam in the Netherlands. When we examine the transnational networks of Indonesian Muslims beyond the Dutch borders we must discriminate between three types of engagements. First, there were a few occasions in which Indonesian Muslims were in contact with organizations abroad for religious purposes. Second, and more importantly, throughout the 1920 s and 1930s there were political events in which prominent Muslims-Indonesians and non-Indonesians - were involved, though not primarily in the capacity of their religious identity. Finally, the Dutch Indonesian Muslims, workers and students, were in frequent contact with the Indonesian community in Cairo that was deeply embedded in religious institutions.

In the period from 1910 to 1939 I have listed forty-two occasions in which Indonesians in the Netherlands were active abroad, or in which foreigners approached the Dutch Indonesian community for political, organizational or religious purposes. With regard to the first type of engagement, I would label only three of the forty-two events as primarily religious. The most important of these was undoubtedly the presence of Mohammed Ali van Beetem at the European Muslim Congress in Geneva in 1935, which Umar Ryad describes in his article on Van Beetem. ${ }^{40}$ The congress was initiated by the well-known Lebanese pan-Islamic organizer Shakīb Arslān, who fostered an influential network of Muslims in Europe from his residence in Geneva, and who in turn was part of the circles around Muḥammad Rashīd Riḍā and Amīn al-Ḥusaynī.

39 Klaas Stutje, "Indonesian Identities Abroad: International Engagement of Colonial Students in the Netherlands, 1908-1931," BMGN—Low Countries Historical Review 128 (2013), 159 . 
The congress was attended by sixty participants, among them European converts, European Muslims from the Balkans, and immigrants such as Messali Hadj from Algeria. For a number of personal and political reasons the European Muslim Congress turned out to be a disappointment: political issues, internal quarrels, and colliding personalities frustrated the establishment of a permanent European Muslim umbrella organization in the home city of the League of Nations. ${ }^{41}$ For Mohammed Ali van Beetem, however, it provided the opportunity to request-half a year after the inauguration of the langgar-community building in The Hague-moral support for the construction of a proper mosque like the mosques in London, Berlin, and Paris. ${ }^{42}$

A second remarkable religious event was the arrival in the Netherlands of an Ahmadiyya-Lahore missionary, Mirza Ali Ahmad Baig, in $1939 .^{43}$ This Indian propagandist founded an Ahmadiyya center on Java and worked at least twelve years in the Dutch East Indies before he was transferred to the Netherlands. There, he aimed to promote the study of Islam among Indonesian students and establish a mosque. ${ }^{44} \mathrm{He}$ also sought contact with Perkoempoelan Islam, where he soon became a respected member. ${ }^{45}$ It seems that World War II put an early end to Ahmad Baig's activities, as the German authorities imprisoned him. ${ }^{46}$ Nonetheless, the presence of one of the two Ahmadiyya branches in the Netherlands is important: it was this outcast reformist movement of Islam that was at the forefront of institutionalizing Islam in other countries in Europe as well. Its activists devoted much effort and missionary resources to establishing a basic Islamic infrastructure, introducing Islam to non-Muslims, and translating the Qur'ān and other important texts into European languages. They took control of the Woking Mosque in London, and initiated the establishment of mosques in Berlin, Vienna, Madrid, and other European cities. ${ }^{47}$

Although the arrival of Ahmad Baig was most likely the first outward attempt to extend the Ahmadiyya network to the Netherlands, there are

41 Martin Kramer, Islam Assembled: The Advent of the Muslim Congresses (New York: Columbia University Press, 1986), 142-153, there 152.

42 Ryad, "Among the Believers," 301.

43 On the Ahmadiyya and its Lahore and Qadiyani branch, named after the headquarters of both branches, see Clayer and Germain, Islam in Inter-War Europe, 89-118.

44 Poeze, Politiek-Politioneele Overzichten, Deel I, lxxx, 200; Idem, In het Land van de Overheerser, 289; Landman, Van Mat tot Minaret, 23-32; Ryad, "Among the Believers," 304; IISH, Stokvis: inv. nr. 228.

45 "De moskee in Nederland," De Indisch Courant (13 December 1939).

46 This information is derived from an interview with the former chair of the Lahore branch in the Netherlands, Mr. Keeskamp: Landman, Van Mat tot Minaret, 29.

Clayer and Germain, Islam in Inter-War Europe, 28-29, 51, 97-100. 
indications that Indonesian students in the Netherlands were in contact with Indonesian Ahmadis abroad before 1939. In 1927, the Dutch police in Leiden raided the secretariat of the nationalist association Perhimpoenan Indonesia under the pretext of the latter's anticolonial sedition. Among other documents, the police confiscated a list of subscriptions of its journal Indonesia Merdeka. Judging from this list, it would seem that the journal was sent to two addresses in Lahore: the first was a certain Ahmad Sarida, a student of the Ahmadiyya Isha'at Islam college, and the second address was that of the Ahmadiyya Anjuman-i Isha'at-i Islam headquarters itself. ${ }^{48}$ From a couple of years earlier, but confiscated during the same police raid, a small postcard to the Indonesia Merdeka secretariat survived, indicating that the same Ahmad Sarida wanted his address changed from the "Ahmadia Buildings Lahore" to the "Ahmadia School Qadian Gurdaspur Punjab." Sarida also thanked Perhimpoenan Indonesia for sending its journal free of charge. "Your journal is instructive for the Indonesian community here in Lahore and Qadian, which comprises 22 souls. May God help us, Indonesians, in our work: to destroy what is evil."49

Although the relations between the Ahmadiyya branches and the mainstream Muslim world have always been problematic, and the Ahmadiyya movement itself was also split into Qadiyani and Lahori branches, the Dutch historian Harry Poeze concludes from an interview with an Indonesian in The Hague that religious disputes did not affect the Indonesian Muslim community in the Netherlands. ${ }^{50}$ While in Cairo an anti-Ahmadiyya association was established by Jawi students from Padang, in the Netherlands the authority of Ahmad Baig seems to have been widely recognized by the Indonesians. ${ }^{51}$

\section{Student Politics Abroad, Merging Networks}

Connections with other Muslim communities in Europe through political networks occurred much more frequently than through religious networks. This implies, however, that the students in Perhimpoenan Indonesia, by virtue of their attempts to establish political contacts abroad, were much more successful than the workers in Perkoempoelan Islam, who did not focus on foreign representation. While only three primarily religious transnational connections

\footnotetext{
48 NA, Koloniën: inv.nr. 300.

49 NA, Koloniën: inv.nr. 301.

$5^{\circ} \quad$ Poeze, In het Land van de Overheerser, 289.

51 On the anti-Ahmadiyya Majlis Asjaura al Indonesia, see NA, Koloniën: inv.nr. 312 and 314.
} 
were established, no fewer than thirty-five events bore a political or semipolitical character, be they loyalist, nationalist, communist, anticolonial, antifascist or pacifist events. ${ }^{2}$ These non-religious events in Europe served as locations for encounters between prominent Muslims in Europe as well. Political, anticolonial, and religious solidarity were often inter-related.

For example, the Kongress gegen Koloniale Unterdrückung und Imperialismus in Brussels in 1927 was organized at the instigation of the Communist International Red Aid and the Comintern, and bore a strong Communist imprint. ${ }^{53}$ Among historians, this congress is usually studied because of its significance to the anticolonial movement. ${ }^{54}$ Several prominent anticolonial organizers and political leaders from all around the world were present, such as Jawaharlal Nehru of the Indian National Congress and the SenegaleseFrench Communist Lamine Senghor of the Comité de Defense de la Race Nègre. However, among its participants we also find the Indian Mawlana Barkatullah Bhopali, who pursued pan-Islamic and nationalist goals through revolutionary action and who spoke on behalf of the Indian revolutionary Ghadar Party. The prominent Muslim Algerian nationalist Messali Hadj, who lived in France and was involved in the network around the aforementioned Shakīb Arslān was also in attendance. ${ }^{55}$ Mohammed Hatta, the Indonesian student who represented Perhimpoenan Indonesia at the Kongress with a mandate of a number of Indonesian organizations and who later became the first vice president of the independent Indonesian Republic, spoke with various groups, among them Messali Hadj and his Étoile Nord-Africaine. ${ }^{56}$ Although the precise content of the discussions is unknown, in his memoirs

52 These activities do not include the many artistic tours of Noto Soeroto and Jodjana, or holiday trips; see Karels, Mijn Aardse Leven Vol Moeite en Strijd, 91-106.

53 L. Gibarti, Edo Fimmen and Moh. Hatta, Das Flammenzeichen vom Palais Egmont: offzielles Protokoll des Kongresses gegen Koloniale Unterdrückung und Imperialismus, Brüssel, 10-15 Februar 1927 (Berlin: Neuer Deutscher Verlag, 1927); NA, Justitie: inv.nr. 166og; IISH, Henriette Roland Holst: inv. nr. 39; Fredrik Petersson, "We are Neither Visionaries, nor Utopian Dreamers, Willi Münzenberg, the League against Imperialism and the Comintern, 1925-1933" (PhD diss., Åbo Akademi University, 2007), 49, 109.

54 Petersson, "We are Neither Visionaries, nor Utopian Dreamers"; Poeze, Politiek-Politioneele Overzichten, Deel I, xcix-ci.

55 Messali Hadj, Les Mémoires de Messali Hadj 1898-1938 (Paris: J.C. Lattès, 1982), 156-157.

56 The other Dutch Indonesian delegates were Nazir Pamoentjak, Gatot, and Soerbardjo (Manaf). The mandate was given by the parties Partai Nasional Indonesia, Partai Sarekat Islam, Boedi Oetomo, and several student societies, united under the banner of Nationale Concentratie. A fifth Indonesian representative was the Communist Semaoen, representing the Sarekat Rakyat. 
Messali Hadj frequently referred to other participants from Indonesia, Syria, British India, Egypt, Senegal, and Tunisia as his "coréligionnaires." ${ }^{57}$

The Lebanese organizer Shakīb Arslān himself was not present at this event in Brussels, because the French and Belgian authorities did not grant him a visa. ${ }^{58}$ However, ten months later, in November 1927 , the Indonesian students and Perhimpoenan Indonesia members Achmad Subardjo and Sulaiman, had the chance to meet Arslān in Moscow, Messali Hadj from Algeria, and Ahmed Essafi from Tunisia. They met on the occasion of the festivities for the tenth anniversary of the Soviet Union. Apart from communist delegations from all around the world, anticolonial nationalists were invited as part of the Comintern's attempt to gain influence in the colonial world. In his autobiography, Achmad Subardjo describes that his friend Sulaiman - 'a pious Muslim'initially hesitated to accept the invitation because he had heard many negative stories about the treatment of Muslims in the Soviet Union. Nonetheless, they accepted the invitation and during their stay joined the aforementioned Muslim nationalists. When Shakīb Arslān gave a speech in the famous Bolshoi theater in Moscow on the Islamic concept of redistributing wealth among the toiling masses, Subardjo and Sulaiman were greatly inspired. ${ }^{59}$

At first sight, the encounters of Indonesian students with prominent Muslim organizers took place within the context of anticolonialism and the struggle for national liberation. At these moments, they do not seem to have provoked profound theological debates or discussions about the role of Islam in society. ${ }^{60}$ However, because the political events took place on a regular basis, the various Muslim communities became aware of each other's existence. It also may have fueled the idea among some European Muslim organizers to build an international platform on religious grounds as well, of which the aforementioned European Muslim Congress is a telling example.

\section{Cairo and Contacts with the Jawi Community}

Finally, in our attempt to explore the connections between Indonesian Muslims in the Netherlands and Muslims beyond the confines of the Dutch

57 Hadj, Les Mémoires de Messali Hadj, 157.

$5^{8}$ NA, Koloniën: inv.nr. 309; "De Liga; het congres te Brussel," De Indische Courant (10 December 1927).

59 Ahmad Subardjo Djoyoadisuryo, Kesadaran Nasional: Sebuan Otobiografi (Jakarta: Gunung Agung, 1978): 140-144; CARAN 13170.

6o See, for example, the conference proceedings: Gibarti, Fimmen, and Hatta, Das Flammenzeichen vom Palais Egmont. 
Empire we must consider the large Jawi community in Cairo. In the same period that Indonesian students started to arrive in the Netherlands, the first cohorts of Indonesians enrolled in al-Azhar university in Cairo. Contemporary Arabs usually referred to this group as the Jawi; in fact this category comprised people from more cultural backgrounds than the Javanese alone. In fact, all Muslim students in Cairo coming from Muslim lands east of present-day Thailand-including a considerable number of Arabs living in Southeast Asia (the Hadhramis) - came under the rule of the Shaykh alJawi. ${ }^{61}$ Nonetheless, the main group within this Jawi community came from the Dutch East Indies, and considered themselves related to the Indonesians in the Netherlands.

These Jawi students, numbering fourteen in 1904, twenty-two in 1912, 150 in 1925 , and around 100 in the 1930s, established organizations and journals just as the Indonesians in the Netherlands had, though usually on the basis of regional background rather than social class or political affiliation, and they were inspired by Egyptian nationalism and pan-Islamism, rather than by anticolonial nationalism and international communism. ${ }^{62}$ The social background of the average Cairene student differed from that of the Dutch students as well. As mentioned earlier, the Dutch students were typically of aristocratic or merchant descent and from the urban centers on Java, whereas the students in Cairo more often came from religious families and were, in half of the cases, from the west coast of Sumatra.

However, despite these differences, the two communities remained in close contact. The main association of Jawi in Cairo, the Djam'iat al Chairijah, sent its journal Seruan Azhar to Perhimpoenan Indonesia, while the latter organization sent its Indonesia Merdeka in return. ${ }^{63}$ When there were internal quarrels and disagreements in Cairo-and these occurred more often in Cairo than in the Netherlands-Perhimpoenan Indonesia tried to mediate. ${ }^{64}$ On international conferences Perhimpoenan Indonesia, through Achmad Subardjo, was authorized to represent the Djam'iat al Chairijah. ${ }^{65}$ And finally, when prominent Indonesians traveled from Indonesia to Europe, or vice-versa,

61 Michael Laffan, Islamic Nationhood and Colonial Indonesia: The Umma Below the Winds (London: Routledge, 2003), 13, 233; Idem, "An Indonesian Community in Cairo: Continuity and Change in a Cosmopolitan Islamic Milieu," Indonesia 77 (2004): 1-26.

62 Laffan, Islamic Nationhood and Colonial Indonesia, 129, 137-138, 219, 229.

63 NA, Koloniën: inv.nr. 300; William Roff, "Indonesian and Malay Students in Cairo in the 1920s," Indonesia 9 (1970), 79.

64 NA, Koloniën: inv.nr. 362.

65 Mohammad Hatta, "Het Brusselsche Congres tegen Imperialisme en koloniale onderdrukking en onze buitenlandse propaganda," Indonesia Merdeka 5 (1927), 16. 
they often made a brief stopover in Cairo. There they visited the Jawi community, as did the Muslim cleric Haji Agus Salim on his way to an international labor conference in Geneva in 1930, and Mohammed Hatta on his way back in 1932. ${ }^{66}$ On at least one occasion, an Indonesian Cairo resident paid a visit to the Indonesian community in the Netherlands. The Minangkabau scholar Djanan Tajib was the first Indonesian to have obtained the degree of 'Ālim from al-Azhar and was the chief editor of the Seruan Azhar. When he studied in Paris for six months in 1926 he took the opportunity to meet Hatta and other Indonesian students in Rotterdam. ${ }^{67}$ In Paris, it seems likely that he was in touch with Indonesian activists such as Mononutu and Subardjo.

Of course, the various contacts between Perhimpoenan Indonesia and Djam'iat al Chairijah were not strictly religious. They probably illustrate the evolution of an idea of (proto-)Indonesian communality more than unity on the basis of Islam. However, as the last organization was well embedded in the religious circles in, and Islamic networks radiating from Cairo, it suggests that the militants within Perhimpoenan Indonesia through their contacts with the Djam'iat al Chairijah were at least aware of the religious, semi-religious or political forces in the Islamic world at the time. ${ }^{68}$

Moreover, on at least at one occasion, the pan-Indonesian relations bore an explicitly religious character. As Ryad describes as well, Mohammed Ali van Beetem and Mohammed Rasjid of Perkoempoelan Islam traveled to Egypt in January 1934 to visit Islamic institutions there. ${ }^{69}$ Van Beetem wanted his conversion to Islam recognized by the highly esteemed rector of al-Azhar University, Muhammad al-Aḥmadī l-Ẓawahīī. With the support of Shaykhal-Jawi Burhan el Din (the official representative of the Indonesian students at al-Azhar's board), a special meeting was summoned with religious dignitaries, Egyptian members of parliament, student representatives, and many individual Muslim students from Europe, Asia, America, and Africa. ${ }^{70}$ The trip was a memorable success and granted Van Beetem the prestige and recognition that he had pursued for years.

\footnotetext{
66 NA, Koloniën: inv.nr. 345 and 381; Poeze, In het Land van de Overheerser, 225.

67 Mona Abaza, Changing Images of Three Generations of Azharites in Indonesia (Singapore: Institute of Southeast Asian Studies, 1993), 5 .

68 On the religious environment of the Djam'iat, and the presence of the Jawi Dalhar at the pan-Islamic conference of 1932 in Jerusalem, see NA, Koloniën: inv.nr. 381.

69 Ryad, "Among the Believers," 298-300; "Perkoempoelan Islam, afscheid Van Beetem," Het Vaderland (28 December 1933). Ryad, "Among the Believers," 298-300.
} 


\section{Concluding Remarks}

The journey of Mohammed Ali van Beetem and Mohammed Rasjid to Egypt in 1934 is a striking example of the organized activity of Muslims in the Netherlands in the prewar period, and an example of "Dutch" Muslim involvement with Islamic networks abroad. It can even be argued that Van Beetem and his fellows in Perkoempoelan Islam were consciously part of a 'European Islam,' as they were in contact with Muslim networks around Shakīb Arslān and with Ahmadiyya missionaries such as Mirza Ali Ahmad Baig. ${ }^{11}$

However, this chapter also demonstrates that we need to take into account the other Indonesian organizations in the Netherlands as well, to get a more nuanced impression of the functions and activities of Perkoempoelan Islam. Rather than being a pan-Islamic organization with transnational connections, Perkoempoelan Islam was, first and foremost, a communal organization with strong roots in the Dutch environment. It was more concerned with the accommodation and representation of Indonesian workers vis-à-vis the Dutch authorities than with networking abroad.

Despite Van Beetem's trips to Geneva and Cairo, other Indonesian groups, such as the students in Perhimpoenan Indonesia, were much more active in exercising 'big-politics' in the Dutch Empire and beyond than the Muslim workers in Perkoempoelan Islam were. If we focus on the only group that manifested itself as Islamic, we risk overemphasizing the significance of a few primarily religious activities of Van Beetem, while missing other, although less 'religious' events and encounters, that were important for the Indonesian community in the Netherlands at large.

Notwithstanding these remarks, the interwar presence of Indonesian Muslims and their various organizations in the Netherlands is significant in the context of several research areas: the history of Islam in the Netherlands, the history Islam in interwar Europe, and Indonesian migration to the Netherlands. Moreover, the story of the relatively small Muslim community in Perkoempoelan Islam is illustrative of the attitude the Dutch authorities and the society at large adopted towards migrant communities in general, and of the strategies these communities adopted to cope with their inherently vulnerable position. As such, this aspect of the colonial past is also a key part of Dutch history. 


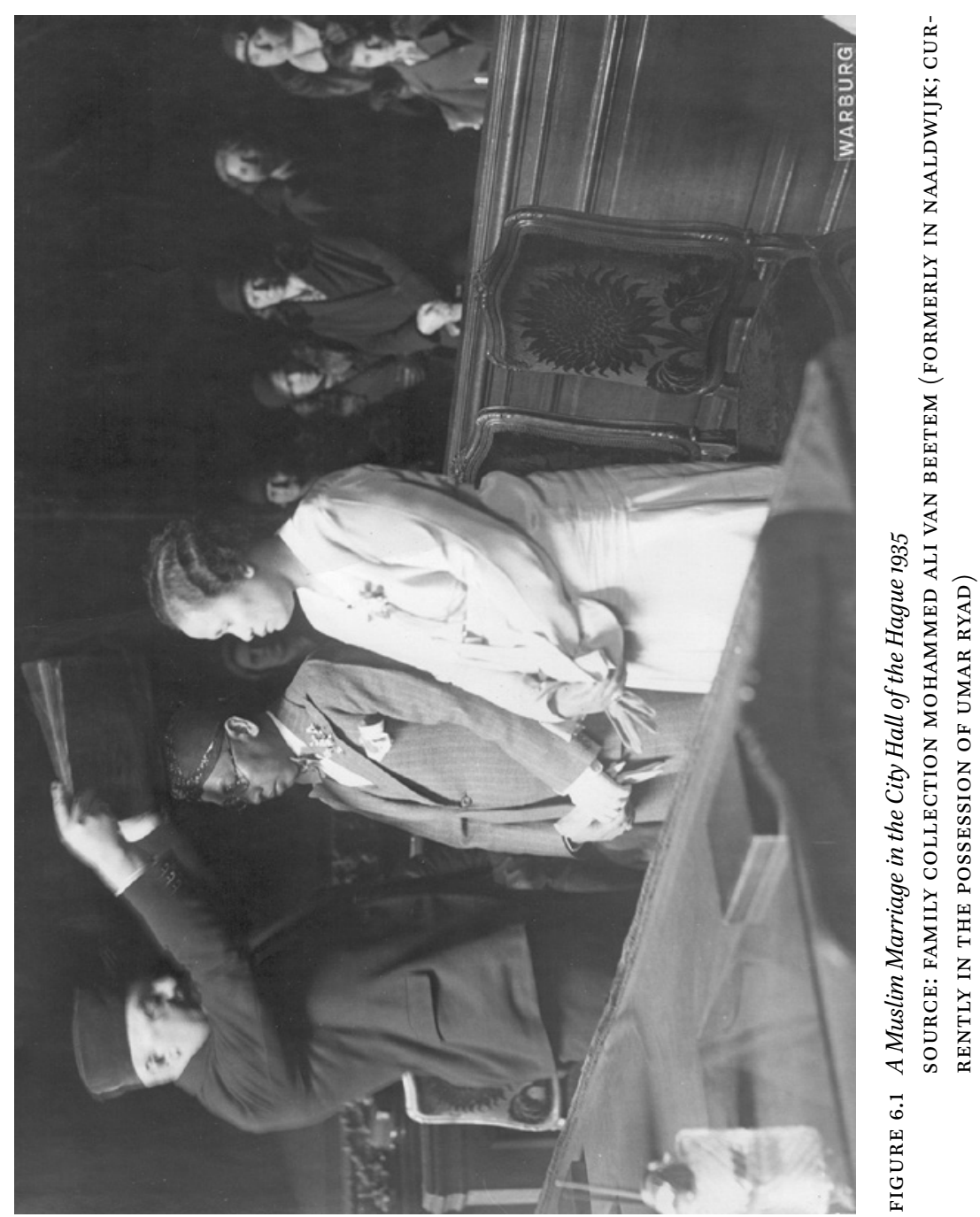




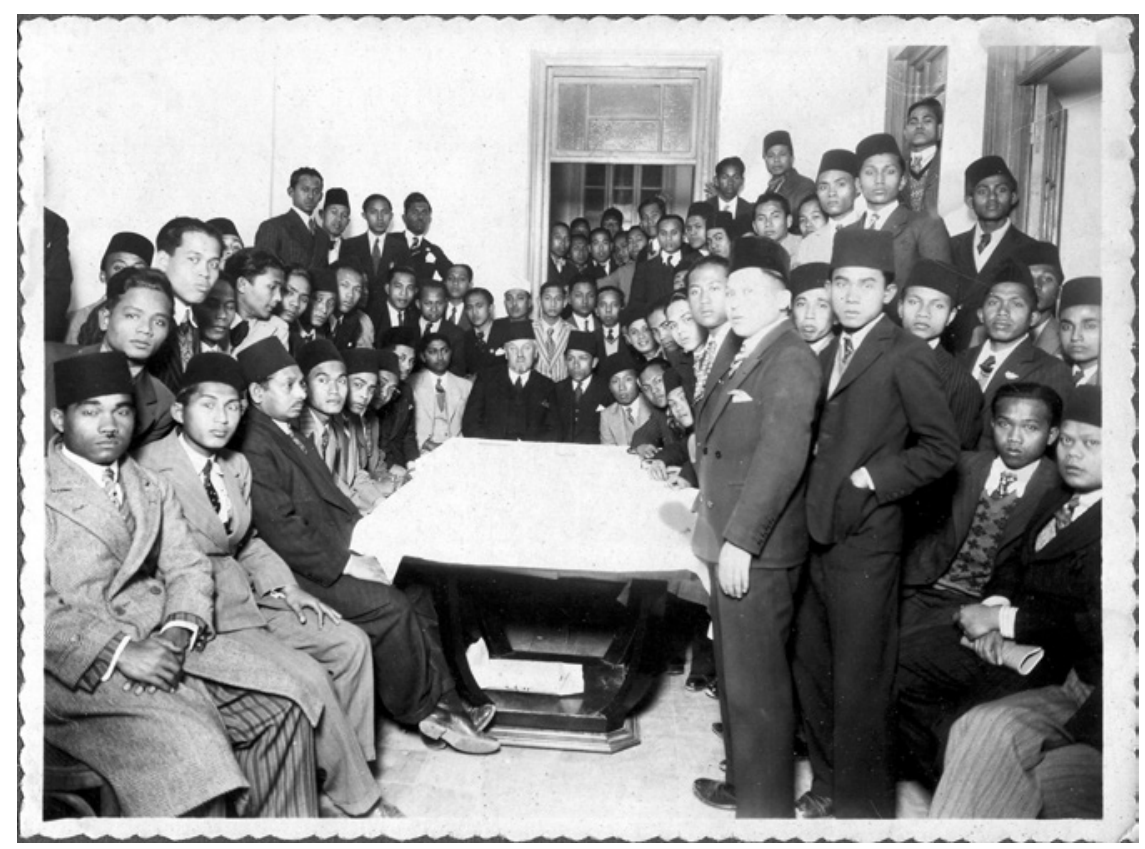

FIGURE 6.2 Van Beetem and Indonesian Students in Cairo 1935

SOURCE: FAMILY COLLECTION MOHAMMED ALI VAN BEETEM (FORMERLY IN NAALDWIJK; CURRENTLY IN THE POSSESSION OF UMAR RYAD)

\section{Bibliography}

\section{Archives}

CARAN $=$ Centre d'Accueil et de Recherche des Archives Nationales Paris. F/7 Police Générale, inventory number 13170, Propagande PCF parmi les indigènes coloniaux. IISH, Henriette Roland Holst = International Institute for Social History Amsterdam (IISH), personal archive Henriette Roland Holst, inventory number 39, collections of articles on the League against Imperialism.

IISH, Stokvis = International Institute for Social History Amsterdam (IISH), personal archive J.E. Stokvis, inventory number 228, Newspaper clippings Achmadyah, Oemmat Islam, studieclubs (etc.).

NA, Justitie = Nationaal Archief Den Haag (NA), Ministerie van Justitie, Verbaalarchief, 1915-1955; Kabinetsarchief, 1915-1940, entry number 2.09.22, inventory number 16609. NA, Koloniën = Nationaal Archief Den Haag (NA), Ministerie van Koloniën, Geheim Archief, 1901-1940, entry number 2.10.36.51, inventory numbers 236; 300; 301; 309; 310; 312; 314; 345; 362; 381 .

De Nederlandse Bank, inventory number 1.752.000.00o 0120 ha 1.7/38, Centrale Inlichtingen Dienst, Jaargang 1934 Overzicht no. 6. Geheim. Consulted via 
online databank, accessed 14 October 2014: http://resources.huygens.knaw.nl/ rapportencentraleinlichtingendienst.

\section{Literature}

Abaza, Mona. Changing Images of Three Generations of Azharites in Indonesia.

Singapore: Institute of Southeast Asian Studies, 1993.

Algemeen Handelsblad. "De behandeling van Nederlandsch-Indiers." 22 June 1933.

. "Islamieten Vereeniging." 9 October 1932.

. "Stopzetting van steun aan Inlanders." 10 March 1935.

Bachtiar, Harsja W. "The Development of a Common National Consciousness among Students from the Indonesian Archipelago in the Netherlands." Majalah Ilmu-Ilmu Sastra Indonesia 6 (1976): 31-44.

Beetem, J.L.Ch. van. “Een Moskee in Den Haag." Het Vaderland. 15 June 1929.

Clayer, Nathalie and Eric Germain, eds. Islam in Inter-War Europe. London: Hurst \& Company, 2008.

Cottaar, Annemarie. Ik had een Neef in Den Haag: Nieuwkomers in de Twintigste Eeuw. Zwolle: Waanders, 1998.

Djoyoadisuryo, Ahmad Subardjo. Kesadaran Nasional: Sebuan Otobiografi. Jakarta: Gunung Agung, 1978.

Elson, R.E. The Idea of Indonesia: A History. Cambridge: Cambridge University Press, 2009.

Geertz, Clifford. The Religion of Java. Chicago: University of Chicago Press, 1976.

Gibarti, L, Edo Fimmen, and Moh Hatta. Das Flammenzeichen vom Palais Egmont: offzielles Protokoll des Kongresses gegen Koloniale Unterdrückung und Imperialismus, Brüssel, 10-15 Februar 1927. Berlin: Neuer Deutscher Verlag, 1927.

Hadj, Messali. Les Mémoires de Messali Hadj 1898-1938. Paris: J.C. Lattès, 1982.

Hatta, Mohammad. "Het Brusselsche Congres tegen Imperialisme en koloniale onderdrukking en onze buitenlandse propaganda." Indonesia Merdeka 5 (1927): 14-20.

_. "De lezing van Stokvis voor de 'Perhimpoenan Indonesia." De Socialist. 8 June 1929.

De Indische Courant. "Indië in Nederland." 29 February 1932.

—. "Indische en Inheemsche werkloozen." 22 June 1935.

. "Indiërs in Nederland: De invloed van extreme elementen, Perkoempoelan Islam." 10 May 1935.

. "De Islam, lezing R.A.A. Wiranatakoesoema." 14 November 1933.

_. "De Liga; het congres te Brussel." 10 December 1927.

.De moskee in Nederland." 13 December 1939.

- "Werklooze Suikergeëmployeerden in Nederland; twee duizend Indische werkloozen?"4 December 1934.

Ingleson, John. "Fear of the Kampung, Fear of Unrest: Urban Unemployment and Colonial Policy in 1930s Java." Modern Asian Studies 46 (2012): 1633-1671. 
_. Perhimpunan Indonesia and the Indonesian Nationalist Movement, 1923-1928. Melbourne: Monash University, 1975.

Karels, René. Mijn Aardse Leven Vol Moeite en Strijd: Raden Mas Noto Soeroto, Javaan, Dichter, Politicus 1888-1951. Leiden: KITLV Uitgeverij, 2010.

Kramer, Martin. Islam Assembled: The Advent of the Muslim Congresses. New York: Columbia University Press, 1986.

Laffan, Michael. "An Indonesian Community in Cairo: Continuity and Change in a Cosmopolitan Islamic Milieu." Indonesia 77 (2004): 1-26.

_. Islamic Nationhood and Colonial Indonesia: The Umma Below the Winds. London: Routledge, 2003.

Landman, Nico. Van Mat tot Minaret: de Institutionalisering van de Islam in Nederland. Amsterdam: vu Uitgeverij, 1992.

Locher-Scholten, Elsbeth. Ethiek in fragmenten. Vijf studies over koloniaal denken en doen van Nederlanders in de Indonesische Archipel 1877-1942. Utrecht: Hes Publishers, 1981.

Lucassen, Jan and Leo Lucassen. Winnaars en Verliezers: Een Nuchtere Balans van Vijfhonderd Jaar Immigratie. Amsterdam: Uitgeverij Bert Bakker, 2012.

Het Nieuws van den Dag voor Nederlandsch-Indië. "Brieven uit het Moederland." 28 October 1932.

Het Nieuwsblad van het Noorden. "Verbond van Nationalisten." 10 March 1928.

Petersson, Fredrik. "We are Neither Visionaries, nor Utopian Dreamers, Willi Münzenberg, the League against Imperialism and the Comintern, 1925-1933." $\mathrm{PhD}$ dissertation, Åbo Akademi University, 2007.

Poeze, Harry A. In het Land van de Overheerser, I: Indonesiërs in Nederland 1600-1950. Dordrecht: Foris Publications Holland, 1986.

- Politiek-Politioneele Overzichten van Nederlandsch-Indië: Deel I-IV. Dordrecht: Foris Publications Holland, 1982-1994.

Roff, William. "Indonesian and Malay Students in Cairo in the 1920s." Indonesia 9 (1970): $73-87$.

Ryad, Umar. "Among the Believers in the Land of the Colonizer: Mohammed Ali van Beetem's Role Among the Indonesian Community in the Netherlands in the Interwar Period." Journal of Religion in Europe 5 (2012): 273-310.

—. "Te Gast in Den Haag: Discussies Moskeebouw in Nederland vóór de Tweede Wereldoorlog." Tijdschrift voor Religie, Recht en Beleid 4 (2013): 59-78.

Schutzman Wider, Joan. "Indonesian Women in The Hague: Colonial Immigrants in the Metropolis." PhD diss., New York University, 1967.

Shadid, W.A.R and P.S. van Koningsveld. Islam in Nederland en België: Religieuze Institutionalisering in Twee Landen met een Gemeenschappelijke Voorgeschiedenis. Leuven/Paris/Dudley, mA: Peeters, 2008.

Stutje, Klaas. "Indonesian Identities Abroad: International Engagement of Colonial Students in the Netherlands, 1908-1931." BMGN_Low Countries Historical Review 128 (2013): 151-172. 
De Sumatra Post. "Perhimpoenan Indonesia; de ervaringen van Stokvis." 8 July 1929.

Sutherland, H.A. The Making of a Bureaucratic Elite: The Colonial Transformation of the Javanese Priyayi. Singapore: Heinemann Educational Books, 1979.

Het Vaderland. "Deelneming der Perkoempoelan Islam.” 29 March 1934. . "Islamietische Begraafplaats." 24 December 1932.

_. "Perkoempoelan Islam." 29 October 1933.

_. "Perkoempoelan Islam." 4 March 1935.

—. "Perkoempoelan Islam." 15 April 1935.

—_. "Perkoempoelan Islam, afscheid Van Beetem." 28 December 1933.

—. "Verbond van Nationalisten." 26 March 1929.

—_. "Verkiezingen Tweede Kamer, de candidaatstelling." 21 May 1929.

—. "Viering van het Indisch Nieuwjaar." 28 January 1933.

Wubben, Henk J.J. Chineezen en Ander Aziatisch Ongedierte: Lotgevallen van Chinese Immigranten in Nederland 1911-1941. Zutphen: Walburg Pers, 1986. 


\title{
Moros y Cristianos: Religious Aspects of the Participation of Moroccan Soldiers in the Spanish Civil War (1936-1939)
}

\author{
Ali Al Tuma
}

\section{Introduction}

The Spanish Civil War, in which around 80,00o Moroccan Muslims fought, was not, initially, supposed to be a holy war in the religious sense. Nor were the majority of the Spanish Nationalist officers who rebelled against the Spanish Republic in July 1936 particularly religious, despite their political conservatism. In fact, it was in the Spanish protectorate of Morocco that the military coup first received its designation as a holy war, and it was the Moroccan Khalifa, the nominal representative of the Moroccan sultan and the highest Moroccan authority in the Spanish zone, who first did so. ${ }^{2}$ In this chapter I discuss the religious aspects of the Moroccan participation in the Spanish Civil War. I examine the idea of a religious alliance between Moroccan Muslims and Spanish Christians against a supposedly atheist enemy from the point of view of Spanish Nationalist propaganda, but also from the point of view of the Moroccan soldiers. I also demonstrate that the Spanish Nationalists portrayed the Moroccans in their Moroccan protectorate as devout Muslims. This portrayal influenced the propaganda the Nationalists used to win the loyalty of the people in Spanish Morocco. With regard to the Moroccan soldiers, many aspects of their daily life was deferred to the notion of the religious Moroccan. The Spanish Nationalist military endeavored to create a separate Muslim religious sphere for the Moroccan soldiers. In this chapter I show that the Nationalist authorities not only wanted to respect the Islamic religion of their troops but also expected the

1 The phrase 'Moros y Cristianos' translates to Moors and Christians. It refers to the battles between the medieval Moors and the Christians in Spain during the age of the Reconquest, and to the festivals in Spain that commemorate and re-enact these battles.

2 Stanley G. Payne, The Franco Regime 1936-1975 (Madison: University of Wisconsin Press, 1987), 197n1. Initially, as Payne states, religious concern did not play an overt role in the rebellion of July 1936, rather it was its counter-revolutionary character that made Catholics natural allies from the start. 
Moroccan soldiers to adhere to the idealized image of devout Muslims, even when some of these soldiers had no desire to comply with that idealized image.

Soon after the outbreak of the Civil War, strange scenes started to emerge: the archbishop of Toledo returned to his archiepiscopal see escorted by Moroccan Muslim troops, a priest accompanied Moroccans into battle, proNationalist crowds cheered and pinned crosses and scapularies on the chests of African soldiers, and many similar scenes. ${ }^{3}$ In Ceuta, the Nationalists authorized the building of a new mosque in which stones from the battlefields of the Alcazar of Toledo, Oviedo, and Teruel were integrated as "official recognition" of the existence of Islam in Spain and as "proof" of the meaning of these "martyred cities" for Muslims. ${ }^{4}$

As a matter of fact the Spanish Republicans inadvertently helped the Nationalist propaganda in portraying this war to the Moroccans as a struggle in which the Republic targeted Islam and Moroccans in particular. Early in the war, Republican planes struck the native medina of Tetuan, hitting a mosque in the process, and later dropped bombs near a ship that was to take pilgrims on their trip to Mecca, while the Republican navy shelled a number of coastal towns in Spanish Morocco. ${ }^{5}$ In August 1936 the Nationalist newspaper Diario Marroquí highlighted an air raid that supposedly targeted the Mezquita of Cordoba, "the historical monument of Arab civilization."

The Nationalists portrayed the struggle against the Republic to the Muslims of Spanish Morocco as a conflict in which religion played a prominent role, because the Nationalists saw and presented the Moroccans as primarily oriented and driven by religion and religious biases. The Moroccans were first and foremost Muslims. It was clear that they were perceived as extremely religious by those who held a negative, hostile view and by those with a benign or

3 Hugh Thomas, The Spanish Civil War (New York: Modern Library, 2011), 400; Claud Cockburn, Cockburn in Spain: Despatches from the Spanish Civil War (London: Lawrence and Wishart, 1986), 161; Ronald Frasier, Blood of Spain: An Oral History of the Spanish Civil War (New York: Pantheon Books, 1979), 155 .

4 Tomas García Figueras, Marruecos: La acción de España en el Norte de África (Madrid: Ediciones Fe, 1944), 292.

5 Balfour, Deadly Embrace: Morocco and the Road to the Spanish Civil War (Oxford: Oxford university press, 2002), 273, 281; Shannon E. Fleming, "Spanish Morocco and the Alzamiento Nacional, 1936-1939: The Military, Economic and Political Mobilization of a Protectorate," Journal of Contemporary History 18, no. 1 (January 1983), 36, 37. The target of the bombing in Tetuan was perhaps the building of the High Commissariat which lies not far from the medina.

6 "Los aviones rojos bombardean la Mezquita de Córdoba," Diario Marroqí, 19 August 1936. The famous mosque-turned-cathedral was not hit. 
paternalistic view of Islam and Moroccans. One Spanish soldier who fought for the Nationalists remarked retrospectively on the "Moors" he met in Melilla in 1936, that they were "in this aspect [being religious] superior to us who never remembered to visit a church."7 García Figueras (1892-1981), one of the most prominent administrators of the Spanish protectorate in Morocco, considered the greatest achievements of the Nationalist administration in Morocco those that took into account the spiritual and religious nature of the Moroccan populace. This understanding applied not only to Moroccans but to the rest of the "Muslim people." In 1939 Franco sent a letter to the association of Muslim youth in Cairo, answering a memorandum that the Islamic conference in Cairo sent to him. In his letter, Franco commended the "Muslim people" for succeeding in preserving their "spiritual treasures" in a materialistic age, and pointed to the blood bonds that were formed with the Moroccan people in defense of the

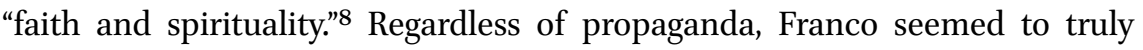
believe that the alternative to a deeply religious Muslim was not a palatable one. In a less public remark he declared that "the Arab without a turban is a future Marxist."9

Of course some of the Nationalist veterans of the protectorate perceived that the religiousness of the Moroccans was neither blind nor absolute. Ruiz Albéniz, also known as El Tebib Arrumi, an important journalist and radio speaker for the Nationalists during the Civil War, observed in the early years of the protectorate that Moroccan religiousness was rather practical in nature and religious observance was ultimately subordinated to profit. ${ }^{10}$ Once one from the Rif does not perceive a threat to his faith, he would be guided by his innate desire for profit and would associate himself with the actions of the protectorate. ${ }^{11}$ But for the Moroccan, that security in faith must first be guaranteed by the Spanish, and a part of that involved communication. The Spanish considered it essential to attach the greatest importance to religious matters when communicating with the Moroccans of their protectorate or when buying their support. One remarkable example from the Republican side

7 Jose Llordes Badía, Al dejar el fusil: Memorias de un soldado raso en la guerra de España (Barcelona: Ariel, 1969), 60.

8 The text was published in the Moroccan newspaper al-Hurriyya, 16 February 1939.

9 Abel Albet-Mas, "Three Gods, Two Shores, One Space: Religious Justifications for Tolerance and Confrontation between Spain and Colonial Morocco during the Franco Era," Geopolitics 11, no. 4 (2006), 593. Tebib Arrumi," Journal of Iberian and Latin American Studies 11, no. 1 (April 2005), 40.

11 Ibid., 42. 
proves the point. Early in the war the communist paper, Mundo Obrero, published what seemed to be a note by a young Moroccan prisoner of war denouncing Franco. The paper published a Spanish translation of the letter as well as a picture of the original. While the Spanish version denounced Franco as a "traitor," we can see that in the Arabic text the word "infidel" is added to "traitor," though the paper omitted this from the translation. ${ }^{12}$ Perhaps the Republican paper's lack of accuracy in translation stemmed from its unwillingness to portray the conflict in religious terms. But this example shows that even when the Moroccan soldier wanted, or in this case, probably felt forced to attack the Francoists he could only do so in terms of religion: believers and infidels. It comes then as no surprise that early in the war Franco paid a great deal of attention to his famous sponsorship of the pilgrimage to Mecca.

\section{El Hajj Franco}

In early 1937 Franco scored one of his most impressive propaganda achievements in relation to the Muslims of the Spanish protectorate and his army: the Franco-sponsored pilgrimage to Mecca. In December 1936 the High Commissariat (the seat of the Spanish administration in Morocco) requested that Franco assign a ship for the Spanish Moroccan pilgrims to sail to Mecca; Franco agreed on the same day and ordered the navy to make the necessary preparations. ${ }^{13}$ At the time the High Commissioner in Morocco was General Orgaz, but it seems that the one behind the idea was the Arabist Colonel Juan Luis Beigbeder, secretary general of the Commissariat at the time and later High Commissioner. ${ }^{14}$ The Nationalist navy prepared a ship that was to depart from Ceuta at the end of January 1937, and which was arranged so as to become a "floating mosque." The Nationalists' air force and navy protected the pilgrimage part of the way until the Italians took over. ${ }^{15}$ Nationalist Spain appointed a

12 María Rosa Madariaga, Los moros que trajo Franco: La intervención de tropas coloniales en la guerra civil española (Barcelona: Ediciones Martínez Roca, 2002), 323-324.

13 Archivo General Militar de Ávila (Agmav), A.1, L.59, Cp. 87. Cables: Generalissimo to Orgaz on 12 December 1936, and Generalissimo to naval general staff on 12 December 1936.

14 This according to his British mistress Rosalinda Powell Fox in her memoirs: The Grass and the Asphalt (Puerto Sotogrande: J.S. Harter and Associates, 1997), 130.

15 See the account by Abdel Krim Kerrisch, a Dutch protégé who accompanied the SpanishMoroccan pilgrims to Arabia; the account can be found in the Dutch national archives: Nationaal Archief, Gezantschap Marokko, 2.05.119, inv.nr. 36. Missive nr.: 821/103. According to this witness, the Spanish warships escorted the pilgrims to Tripoli. According to a Spanish document, the plan was to provide protection, which would be "indispensable until" the 
consular agent for Jeddah and Mecca. The choice for this position fell on a Muslim officer of the Regulares (though of Spanish nationality). ${ }^{16}$ Franco also prepared an audience for the pilgrims in Seville upon their return in March. This gesture was not an easy matter, given the fact that much of the Spanish navy had fallen into the hands of the Republicans at the start of the Civil War, and Franco could not easily dispense with any ships. In the words of Rosalinda Fox, it was "like asking Whitehall [British War Ministry] in the middle of a war to release half of the Royal Navy."17

The Francoist pilgrimage not only helped Franco's message that he was a friend of Islam, it shined in comparison with the transport the French provided for the Algerian pilgrims, and strengthened Franco's credentials even more. ${ }^{18}$ One of the fruits of this propaganda was evident in the words of the Khalifa in Tetuan, who described Franco as the "protector of Islam." ${ }^{19}$ Next to its political benefits in Spanish Morocco itself, the pilgrimages must have left an impression on the soldiers fighting in Spain too. It is probably due to this pilgrimage, and others that followed during the course of the war, that Franco became known as El Hajj Franco (the pilgrim Franco), a title the northern Moroccans and his ex-soldiers used for a long time. ${ }^{20}$ For some he remains to this day a good man partly because "he had the character of Muslims."21

Oran meridian, from where the Italians could take over. AGAMV, A.1, L.59, Cp. 87. Note by Generalissimo HQ on 25 January 1937.

AGAMV, A.1, L.59, Cp. 87. Note by Generalissimo HQ on 25 January 1937. Regulares is short for Regulares Indígenas, which refers to military units composed of native Moroccan soldiers and a corps of officers who were largely Spanish. The forces were founded in 1911 to help combat Moroccan rebels; they became part of the Spanish army and therefore had, officially, a different status, compared to the Mehal-la units that belonged to the Moroccan government, but were also largely commanded by Spanish officers. They were called "Regulares" because they were full-time soldiers who conducted regular army missions, and this also distinguished them from the irregular auxiliary groups of natives who helped the Spanish army.

17 Powell Fox, The Grass and the Asphalt, 130.

18 See the account by Abdel Krim Kerrisch in the Dutch national archives.

19 AGAmv, A.1, L.59, Cp.. 87. Cable by the office of the High Commissariat.

20 Mohamed Choukri mentions, in his internationally acclaimed autobiographical novel alKhubz al-hăfi (known in English as 'For bread alone'), those who were disabled in the Civil War in Tetuan, some of whom "were proud of it for it allowed them to have adventure and to have memories of the battles they fought whether victorious or defeated. The Caudillo was called El Hajj Franco among them." Mohammed Choukri, al-Khubz al-hăfi (Casablanca: Le Fennec, 2010), 28. I even heard this "Hajj Franco" reference in Tetuan in early 2011.

21 Interview with Abdessalam Mohammed Amrani, a veteran of the Spanish Civil War, Ceuta, June 2011. 


\section{A Religious Alliance?}

In the struggle to save Catholic, spiritual, and traditionalist Spain, the Moor who was the old enemy of these three had become the ally of the regenerated traditional country. It certainly was not a self-evident development and it was sometimes an uncomfortable one and it required some justification for at least a part of the masses that the Nationalists appealed to. One Nationalist Catholic writer commented, perhaps uneasily: "It does not matter that next to Christians, the turbans of Mohamed are seen. The sword is of rich Toledan steel, even if the hilt had an Arab enamel, and the Moors and Christians were united in some of the endeavors of the medieval Christian kingdoms." ${ }^{22}$ One Nationalist newspaper, $A B C$ Sevilla, while commending the Moors of whom "no one put a step backwards" went further by calling Morocco the "Covadonga of the current reconquista" in a reference to the place that symbolized the birth of the first successful Christian resistance to the medieval Muslims and the start of the Reconquista. ${ }^{23}$ In one anecdote, the Spanish priest and Arabist Miguel Asín Palacios related that in one hospital a print of the Virgin was going to be removed so as not to hurt the feelings of the wounded Moroccans, and a Moroccan protested against the removal, stating "the Virgin is good for everyone."24 The priest used this anecdote to demonstrate how much these Moroccans had in common with the supposedly true Spanish.

In 1940 Miguel Asín Palacios published a paper called "Why did the Muslim Moroccans fight on our side?" In one of the most eloquent of the Nationalists' rationalizations of the Moroccan participation, he answers:

Below the rugged crust of these simple and brave Moroccan soldiers, beats a heart that is identical to the Spanish, which renders reverence to some other-worldly ideals, not very dissimilar to ours, and which feels the religious emotions which we feel, because it follows many of the Christian

22 From an article entitled "El Cerro de los Angeles y el General Varela," La Correspondencia de San Fernando, 9 November 1936. The copy of the article cited here is in Archivo Histórico Municipal de Cadiz (AHMC), Varela, doc. 15/22.

23 "Marruecos: Covadonga de la actual reconquista," ABC Sevilla, 17 July 1938, 24. Ironically the "Moors" contributed to the occupation, in October 1937, of that place.

24 Miguel Asín Palacios, "Porqué lucharon a nuestro lado los musulmanes marroquíes," in Obras escogidas iI y III de historia y filología árabe, ed. Miguel Asín Palacios (Madrid: Viuda de Estanislao Maestre, 1948), 136. He published this text first in 1940 in the Boletín de la Universidad Central in Madrid. 
dogmas which we follow and which atheist Marxism repudiates and persecutes. ${ }^{25}$

To illustrate that this was not a figment of his imagination, he referred to a Moroccan soldier who allegedly used a hand-grenade to intimidate a "Marxist" soldier by crying in Spanish "Tú no estar de Mahoma! Tú no estar de derechas!" [You are not of [the followers of] Mohammed! You are not one of the Right!]. ${ }^{26}$

One wonders whether the position that Palacios took was representative of the Spanish Catholic clergy, even in the mere propagandistic sense. Let us consider two views, those of a priest and a bishop, both captured by the Republicans. Their situation as prisoners of war renders their statements less than ideal and somewhat unreliable, but it is interesting because it shows the Republicans asking representatives of the Church about why it stood in the same camp as the Moors. In January 1938, the priest García Blasco was captured by the Republicans during the battle of Teruel. During his interrogation he was asked whether he ever thought of protesting against the use of Moroccan troops by the Nationalist command. The priest answered: "Not in public. But of course during private conversations I commented upon it, that the old history would feel disturbed when the greatness which we acquired by fighting Islam would look like a lie now that we are fighting alongside those who used to be our enemies." ${ }^{27}$ As a prisoner, the priest might naturally have given his interrogator the answer he wanted, although his other answers with regard to morale in the Nationalist rearguard - which he described as high — was not what a Republican would necessarily wish to hear.

But ingratiating oneself to an enemy interrogator does not seem to be the case with Bishop Polanco who was also captured in Teruel. When questioned in January 1938 about the presence of the Moroccan troops in Spain, he answered that he saw nothing wrong in Franco using them, for Franco saw them as "soldiers in the service of Spain." When the interrogator pressed that it was strange that the Church, after long years of fighting the Muslims, was now coexisting with them, and asked whether that could be considered the Christian order of things, the bishop answered in the affirmative. He stated that, in his opinion, history has witnessed many occasions in which people from different religions form alliances to fight an enemy, alliances that were

\footnotetext{
25 Asín Palacions, "Porque lucharon," 148-149.

26 Ibid., 145. By "Right" he meant of course the Nationalist camp that was usually referred to as "people of the Right" as opposed to the Republican Left.

27 Interrogation of the priest García Blasco, dated 13 January 1938. Archivo General de la Guerra Civil (AGGC), Caja 58/8.1
} 
based on a "perspective that had nothing to do with religion."28 Asín Palacios's grand depiction of Muslim-Christian brotherhood may have been a minority voice among the Spanish clergy after all, even if it was offered in the cause of propaganda. Perhaps his sympathies with the Moors derived more from his background as an Arabist than as a priest.

The positive image of the Moroccan soldiers as devout allies in a common struggle is at odds with the extremely negative view that most of the Spanish, including many in the military, had of the Moroccans a couple of decades earlier. Centuries of embedding the image of the Moor as a traditional enemy were strengthened by the military engagements of the nineteenth and early twentieth centuries in Morocco, especially during the colonial war (1920-1926) against the Rif rebels of Muḥammad b. 'Abd al-Karīm al-Khațțābī, when Spain suffered one the most humiliating colonial defeats in the battle of Annual in 1921. Racist attitudes towards the Morrocans were prevalent among the vengeful officials, soldiers, Spanish politicians, and the press, who described the Moroccans as uncivilized, xenophobic, fanatical, brutal, degenerate, and deceitful. Some even called for their complete extermination. But at the same time there were some who felt an attraction to Moroccan culture and recognized a shared history between Morocco and Spain and even saw the Moroccans as younger brothers. In fact, many Spaniards displayed contradictory responses towards Morocco and the Moroccans, and the course of the brutal colonial war in Morocco, which ultimately ended with a Spanish victory, had its effect on the development of the image of the Moroccans in the eyes of the Spanish. ${ }^{29}$

In any case, the Moor, the fanatic foe of the recent Rif wars, was rehabilitated in Nationalist Spain by the Nationalist state, by its leading military figures, and its propaganda machinery, which included press, the film industry, and poetry. ${ }^{30}$ This rehabilitation was perhaps not difficult to accomplish. It required a simple adjustment to the presentation of basically the same image of the Moor. As the irrational Moor became simple, childlike, and innocent, so the fanatic became pious, in fact spiritual. The Nationalists forbade foreign journalists - and we must presume Spanish ones too-from describing the Moroccans in any way except as devoted God-fearing soldiers. ${ }^{31}$

28 Interrogation of Bishop Polanco, dated 28 January 1938. AGGC, Caja 58/8.1. During the collapse of the Republican army in Catalonia in early 1939 both the priest and the bishop were shot.

29 Balfour, Deadly Embrace, 193-200.

30 On the aspects of this rehabilitation, see Madariaga, Los moros que trajo Franco, 345-364.

31 Judith Keen, Fighting for Franco: International Volunteers in Nationalist Spain during the Spanish Civil War, 1936-1939 (London: Leicester University Press, 2001), 69. 
The view of the Moroccan soldiers as religiously devout and controlled by religious prejudices, which was in turn derived from the same view the Spanish had of the Moroccan society that they ruled, was behind both the explanations the Nationalists gave to the outside world with regard to the motivations of the Moroccan soldiers for fighting in Spain and the policies of the Nationalists with regard to the actions of the Moroccan soldiers in their Spanish environment, especially those involving direct religious aspects. The actions of the "Moorish" troops, their lifestyle, the incentives etc., were supposed to be shaped by or directed towards their Muslim-ness. In fact, this sometimes mixed with wishful thinking, and it is here that we try to explore the border between the two, starting with the supposed religious motivations of the Moroccans for fighting against the Republic.

\section{Jihad}

While the Spanish Nationalists promoted this idea, the Moroccans were not far behind in their support of it. The native urban political elite helped the religious interpretation for the enlistment of the Moroccans to fight in Spain as well. The day after the official end of the Civil War, al-Hurriyya, the daily of the Spanish Morocco-based Nationalist Reforming Party, expounded on the circumstances and motives of the Moroccan soldiers who went to Spain. The newspaper rejected any notion that economic motives were primarily behind the enlistment of the locals. Instead it listed other reasons, among which was the fear for their "religious sentiments." "For Communism has run rampant and dominated these lands [Spain], for the Muslims are, by the nature of their situation, staunch enemies of the idea of equality in wealth."32 Either this merely and blindly followed the Spanish Nationalist line or the paper could not accept the stigma that comes with the notion of the mercenary, or both. ${ }^{33}$

32 al-Hurriyya (2 April 1939). It also claimed that the Islamic world "supported us in our position, despite some mad campaigns directed against us from some Muslim countries. Those campaigns were the result of hire and bribery by France or Communism itself."

33 I am inclined to believe the second interpretation, because al-Hurriyya, both during and after the war, was not devoid of articles criticizing aspects of the Spanish Nationalist administration, nor of warning Spain against the consequences, should it fail in the fulfillment of its promises towards the Moroccans after the war. The newspaper of the other and rival Moroccan nationalist party, al-Wahda al-Maghribiyya (Unidad Marroquí; Moroccan Unity), also claimed that the Moroccans did not fight for money, for "feelings can not be bought or sold, but because of the honest belief that the victory of Spain will immediately bring victory for the cause of the Moroccan people." But it did not explicitly 
The pro-Franco political forces, be they Spanish or Moroccan, might have used the religious element in their propaganda to justify the participation of Moroccans in the war, but it was apparently an impression that even some on the Republican side believed. ${ }^{34}$

The Nationalists went to great lengths to portray the enlistment of their Moroccan troops as ideologically motivated, but historians have found this interpretation difficult to defend. Maria Rosa Madariaga and Sebastian Balfour, convinced as they are that the volunteers who filled the ranks of the Moorish units in the Spanish peninsula joined for purely economic reasons, reject the idea that there were any higher ideological causes behind the participation of the Moorish troops in the Civil War. For them, and perhaps the majority of those studying the Spanish Civil War, the issue was quite simple.

The issue is less simple for two Moroccan historians who seem convinced that the religious appeal of the cause, propagated by Franco's agents, was an important factor in the decision of Moorish recruits to enlist in the Spanish Nationalist army. According to El Merroun, Franco's rhetoric about Communism and its destruction of Christianity and Islam left an impression on the Moroccan troops. He cites a Moroccan soldier "In Spain ar-rojo [the red one, the communist] comes, burns shrines, kills saints. Moor comes to help Franco fix Spain." ${ }^{35}$ Indeed religion was an important aspect in pulling the Moroccans towards the Nationalist Spaniards. ${ }^{36}$

Ibn Azzuz Hakim (perceived in Morocco as one of the most prominent historians working on the history of the Moroccan nationalist movement and northern Morocco) attacks in an angry tone the historians who did not trouble themselves with the real reasons for the Moroccan participation in the war. According to him, the real reasons were that "the agents of Franco wanted to give the Muslims the opportunity for Jihad alongside the People of the Book, the believers in one God, against the Infidels" and that the Moroccans "entered the war alongside the Catholics of Franco for religious solidarity." ${ }^{37}$

cite Islam as a factor in siding with the Nationalists. See "La guerra ha terminado. Marruecos confía en la palabra del caudillo de España," Unidad Marroquí (3o March 1939). One Canadian volunteer in the International Brigades, Jules Paivio, remembered decades later the "Moors" who believed "it's an honor to die for Allah, so they keep coming at you. They won't stop." From the TV documentary series Battlefield Mysteries, episode "The Lost Graves of the International Brigades" (produced by Breakthrough Entertainment, Canada, 2008).

35 Mustapha El Merroun, Las tropas marroquíes en la Guerra Civil española (Madrid: Almena ediciones, 2003), 40.

36 El Merroun, Las tropas marroquies, 224.

37 Mohammed Ibn Azzuz Hakim, La actitud de los moros ante el alzamiento: Marruecos 1936 (Malaga: Algazara, 1997), 45. The historian José Luis de Mesa does not explicitly endorse a 
He continues: "some chiefs of Muslim brotherhoods, paid by the Francoists, were spreading in low voice the news that general Franco had converted to Islam" and was waging a campaign against "those without god." In fact, Hakim regards as unfair the view that the "Moors" died or became handicapped for a cause that was not theirs, and were only attracted by money and as simple mercenaries. ${ }^{38}$ It appears that both historians base these opinions mainly on the discourse of the Spanish Nationalists and the Moroccan nationalists and collaborating elite. El Merroun and Ibn Azzuz Hakim are motivated by the morally negative presentation of the Moroccan soldiers as pure mercenaries attracted solely by money and the prospect of looting.

Ironically, the voice of those about whom the debate of religious motives revolves, is the voice least heard. The historians of the 1990s and early $2000 \mathrm{~s}$ rarely if ever based their statements on the views of the soldiers whose motives they interpreted, or even took the trouble of citing them to support arguments in favor of or against this religious aspect of the conflict. Of course it is not an easy matter for historians now. There are only a few indications and examples to help us understand the views of the Moroccan soldiers with regard to the religious nature of their struggles in Spain, and the image that arises from these examples is still a mixed one.

In March 1938 a group of spokesmen for the 6th Tabor of the Regulares Ceuta and for the wounded soldiers in the Granada military hospital sent a letter to the military controller (interventor) in Seville complaining against one of the Muslim clerics serving in Spain. After the death of a number of soldiers during the "jihad," this cleric refused to wash the bodies of the "mujähidinn," to lead the prayers for their souls or even to attend the funerals. Adding insult to injury, he stated that "everyone who died in the lands of Spain was an infidel and a half." 39 The complaint denounced this man and called him "red." This document is notable for its use of the terms "jihad" and "mujähidīn" to describe

view on the issue of possible ideological motivations for Moroccan troops fighting for Franco, but the way he presents historical opinions and citations leads one to believe that he agreed with the views of Ibn Azzuz Hakim. Mesa quotes a Moroccan, who was apparently a young friend, saying that "it was natural. Mohammed and Christ proclaimed and represented God who was rejected by the Reds. That is why we could stand with the Christians against them." See José Luis de Mesa, Los moros de la guerra civil española (Madrid: Actas, 2004), 124.

38 Hakim, La actitud de los moros, 45.

39 Archivo General de la Administración (AGA), Af, 81.1179, Leg. 3962, Letter from notables of the 6th Tabor of Ceuta to Sanchez Pol (in Arabic). There is a Spanish translation accompanying the letter which replaced "jihad" with "operations" and "mujāhidīn" with "soldiers." 
the war in Spain and its Moroccan participants, but also for its labeling those who disputed the religious legitimacy of fighting in Spain as "red."

The term "jihad" also appears in the recruitment calls that circulated in Spanish Morocco. One important source is the personal archive of Mustapha El Merroun, which includes scores of interviews with Moroccan veterans. ${ }^{40}$ One of these Moroccan veterans described the recruitment by stating that the $q \bar{a} i d s$ (tribal chiefs) shouted "O servants of God! Those who wish to perform the Jihad, the Jihad has now returned."11 On the battlefield itself, the attacking waves of the Moroccans started with cries exalting God or the Prophet Muhammad. Ruiz Albéniz, the Nationalist propagandist, cites one such cry "Jandulilah! La [Ilaha] Illa Allah, Sidi Mohamed Rasul Allah..." [Mobilize for Allah, there is no god but Allah].$^{42}$ According to Sanchez Ruano, ${ }^{43}$ the Moroccans entered the battle crying "Allah Akbar." A more typical charging battle cry commenced with praise of the prophet: "O lovers of the prophet, pray on him," only to end with "heaven is for the patient, and hell is for the infidels." ${ }^{4}$ Do such religiously inspired battle cries necessarily mean that the soldiers, or the majority of them, believed at the time that they were fighting for a religiously sanctioned cause? Or do they merely reflect the cultural background of the Moroccans, for whom it would have been inconceivable to have come up with any other sort of verbal encouragement? Or is this simply a confirmation of the view that everyone is religious in the trenches? There is no easy answer, but such examples make it difficult to dismiss out of hand the notion that religion played a role in how the Moroccan volunteers viewed or justified their part in the war.

Regardless of whether or not the Moroccan soldiers actually went to war motivated by the moral message that this was a holy war, it seems that many, if not the majority, deemed their Republican opponents on the wrong side with regard to godly matters. We see this in the way the veterans describe the

40 During the 1990s El Merroun conducted interviews with Moroccan veterans of the Spanish Civil War. He kindly offered me special access to these transcripts. I refer to this personal archive as El Merroun papers.

41 Clerics also called on the people: "O servants [of God]! The bread will come from them [the Spanish], the munitions from them and the weapons from them." Testimony of El Sebtaoui, El Merroun papers.

42 Víctor Ruiz Albéniz, Las cronicas de El Tebib Arrumi, Tomo II, Campañas del Jarama y el Tajuña (Valladolid: Librería Santarén, 1938), 35. The author might have misheard the cry, which is perhaps why he missed the "Ilaha" which means "god."

43 Francisco Sánchez Ruano, Islam y Guerra Civil Española, Moros con Franco y con la República (Madrid: La esfera de los libros, 2004), 233.

44 Interview with Abdessalam Amrani, Ceuta, June 2011. This veteran still believed, in 2011, that they emerged victorious because God stood on their side. 
Republican rojos or reds. According to one Moroccan, "the rojos killed the monks and destroyed the churches so they believed only in the hammer and sickle."45 A similar definition of a rojo was "the enemy of Spain or the criminal who abandoned his religion." 46 The first impression the "reds" left upon the memory of another soldier was equally typical: "When we went [to Spain] we found that the rojos were burning churches." ${ }^{37}$ It followed that if a Moroccan defected to the reds "he would die as an infidel."48 One veteran told Sánchez Ruano that the Moroccan soldiers would not desert to the Republicans, for they thought that "if they died, they would go to heaven for performing the Jihad."49 So for the majority of Moroccan soldiers, the Nationalist propaganda about a holy war succeeded, at least in convincing Franco's Muslim soldiers that if they were not on the right side of the conflict, at least they did not stand on the wrong side.

\section{Letters and Graves}

Since the Nationalists perceived and presented the Moroccan soldiers fighting in Spain and the Moroccan population of the protectorate in general, as religious beings first and foremost, it was natural that the Nationalists took great care not to offend the religious feelings of their Muslim soldiers. Sometimes this happened at the request of the Moroccan soldiers themselves, other times at the request of higher Moroccan authorities, and at times even when this care was not asked for. This attention to policies manifested itself in many aspects of the daily lives of the Moroccan soldiers, for example, on Muslim religious festivities Moorish detainees (troops incarcerated for different offenses) were released as a sign of respect for the religious feelings of the Moorish troops; ${ }^{50}$ this was a clear assertion of the pro-Islamic stance of the Francoist government. Other aspects such as correspondence paper, graveyards, diet, conversions, and especially life in hospitals display the great lengths the Nationalists went to create a religious space in which, the Nationalists believed, their Muslim soldiers wanted to remain.

45 Testimony of Abdel Kader Amezian. El Merroun papers. "The Spanish took us to the Churches and we found them ruined and the idols destroyed. So they told us 'are these people going to be successful?', he continues.

46 Testimony of El Bubakra. El Merroun papers.

47 Testimony of El Ayyashi. El Merroun papers.

48 Testimony of Messoud, a corporal. El Merroun papers.

49 Sánchez Ruano, Islam y Guerra Civil, 233.

5o See, for example, Agmav, C.2374, L.145, Cp. 63. 
One aspect of the military policy of respecting the religion of their Muslim troops or, alternatively, the policy of maintaining a safe distance between the religious sphere of the Moroccans and that of the Spanish was manifested in the issue of letters the soldiers sent home to their families. These letters were naturally subjected to censorship. In February 1938 the political section of the High Commissariat in Tetuan wrote to the chief of staff of the Morocco forces expressing the concern of the political section that many Muslim soldiers were sending letters to their families on a kind of stationery with Christian religious symbols printed on it. ${ }^{51}$ To correct the mistake, considerable effort and time was invested in the arduous task of copying the letters on a different type of paper. There were already requests (going back as far as October 1937) to closely monitor the type of paper used by the Muslim soldiers. ${ }^{52}$ The February 1938 complaint suggested measures that involved the coercion of vendors accompanying the units to carry a different kind of paper. More importantly, and to understand what annoyed the author of the angry complaint (and it was one of many similar complaints), was the argument that the use of the aforementioned kind of paper would contribute to the rumors of Christian missionary activities among the Muslim troops. ${ }^{53}$ This was a concern that the Nationalist military authorities reiterated several times in relation to other aspects of the daily life of the Muslim soldiers.

Graves formed another aspect of the religious policy that must have been of more emotional importance to the Moroccan soldiers than the letters were. We can say with certainty that no Moroccan soldier (or at least almost none) who died during the Spanish Civil War was returned to Morocco for burial. They were all buried in Spain, as were almost all those of foreign nationality who participated in the war in great numbers. ${ }^{54}$ In many cases and during the heat of battle, it was not possible to bury the dead Moroccan soldiers in proper cemeteries, and these fatalities were buried where they died, sometimes collectively. In some cases the dead were buried with the Christians, especially in the beginning. ${ }^{55}$ Whether by their own initiative or in response to the demands of Moroccan soldiers, the Spanish started to separate the burial places. According to a veteran "during one of the battles, the dead were mixed,

$51 \quad$ AGA, Af, 81.1122, Cp. 4.

52 AGA, Af, 81.1150, Missive: Exp./5429.

53 AGA, Af, 81.122, Cp. 4.

54 For example, 4,175 Italian dead were buried in Spain, with scores of others buried elsewhere or lost at sea. Brian R. Sullivan, "Fascist Italy's Military Involvement in the Spanish Civil War," Journal of Military History 59, no. 4 (October 1995), 713. 
so they [the Spanish] looked for the Muslim corpses to bury them. So they took the trousers off the dead to see who was circumcised." 56

When burial in a proper cemetery proved possible, it seems that the Nationalist army tried to provide for separate Muslim cemeteries fairly early in the war. In October 1936, the chief staff of General Varela instructed the military commander of the northern town of Vargas (near Santander) to send all Moorish soldiers killed in fighting or dead as a result of sickness to Talaveral de la Reina to be buried in the "Moorish cemetery" there. ${ }^{57}$ There were also those who died later in hospitals as a result of their wounds. As these Moroccan soldiers were usually treated in so called "Muslim" hospitals, the Nationalist military authorities required the hospitals to take careful measures when burying the dead Muslim troops, so that even if they were to be buried in a Catholic cemetery, the deceased Muslims should have their own separate section within the cemetery and, if possible, a separate entrance point. ${ }^{58}$

It is not clear whether the idea for separate Muslim cemeteries first came from the Spanish Nationalist army or from Moroccan officials. In March 1937 a Moroccan minister from the Spanish zone of Morocco visited Spain and suggested that Muslim hospitals dedicate a place for burying the Muslim dead; ${ }^{59}$ this suggestion was welcomed by the Nationalist authorities and included in subsequent instructions for military hospitals. But as we have seen there was already a Moorish cemetery in Talavera in 1936. The use of some of the cemeteries for Muslim soldiers was re-continued, decades later, by the (migrant) Muslim communities of Spain (e.g. Granada. See Figure 7.1).

The efforts to provide for separate burial space for Moroccan soldiers continued after the war. In 1940 the Spanish Ministry of Foreign Affairs requested (at the request of the Moroccan authorities) that efforts be undertaken to determine the burial places of many Moroccan soldiers with the goal of separating the Muslim dead from the Christians. ${ }^{60}$ It seems that no one managed to find the burial places of all the Muslim dead, and many are unidentified to this day. ${ }^{61}$

\footnotetext{
56 Testimony of El Sebtaui. El Merroun Papers.

57 Aнмс, Varela, 14/389.

$5^{8}$ Directorate of Moroccan Affairs in Spain, January 1938. AGA, Af, 81.1122, L.2958, Cpt.3.

59 AGMAV, C.2396 A.2, L.19o, Cp 14. Letter in Arabic.

6o AGA, Af, 81/1114. Leg, 3747/2, Cementerios.

61 The request by the Ministry of Foreign Affairs resulted in some findings. Among the regions that answered the request were Toledo in which 614 dead Moroccans were identified plus an undetermined number in Seseña and Puente del Arzobispo; Barcelona with 28 plus two questionable cases; and Guadalajara where 43 were buried. According to some of these responses, in a few cases the dead were shot by firing squads.
} 


\section{Conversions}

If writing letters on paper with Christian symbols caused enormous irritation with the bureaus of native affairs and the Spanish military, then the conversions of Moroccan soldiers raised great alarm. Such proselytizing activities apparently happened only in hospitals, as these were the places where priests might have enough time to engage in the process. The military authorities were never happy with Spanish religious personnel roaming around inside hospitals where wounded Moroccan soldiers were treated. It was probably in November 1936 when a report by the army inspector brought to the attention of Franco for the first time the disturbing effects of the efforts of the "señoritas" and priests to convert the injured Moroccans to Catholicism. ${ }^{62}$ Immediately, Franco instructed military hospitals to "respect the religious creeds of the natives."63

It appears, however, that missionary zeal still persisted in some places. In November 1938 the Inspector of Moroccan Affairs suggested more active observation of non-hospitalized people entering hospitals, and advised that some sort of tough talk should be undertaken with religious authorities. ${ }^{64}$ Copies of a telegram by Franco forbidding the conversions of Moroccans were supposedly hung in some hospitals "in big letters." 65 The generalissimo himself personally demonstrated his will and dissipated any doubts as to the sanctity of the Islamic space of his Muslim soldiers. One day he arrived at a hospital for a quick inspection. Entering a ward where wounded Moorish soldiers were being taken care of, he looked around and noticed a couple of crosses hanging on the walls of the ward. He obviously did not like that and ordered them to be removed immediately. ${ }^{66}$ Nevertheless and despite all the stern warnings and precautions, there were individual cases of Moorish soldiers who converted to the Catholic faith. In 1938, for example, the Directorate of Moroccan Affairs in Spain reported such a case. The directorate reported on the conversion of a Moorish soldier named Bin Kiran. This case was especially difficult because the conversion happened under the auspices of General Moscardó, the famous protagonist of the siege of the Alcázar of Toledo. Still, the report instructed

62 AGmaV, A.1, L.59, Cp. 86. Report on 19 November 1936.

63 AGMAV, A.1, L.59, Cp. 86. Cable by the army of the north on 27 November 1936. It reported that the instructions of Franco, on 24 November, were communicated to the hospitals of that army.

64 AGA, Af, 81.1113, Cp 3.

65 AGA, Af, 81.1150.

66 Antonio Corral Castanedo, Esta es la casa donde vivo y muero (Valladolid: Ateneo de Valladolid, 1992), 236. 
directors of military hospitals to warn charity sisters as well as nurses of the damage their proselytizing activities would cause to the National Movement. The damages would include reversing years of work done in the Protectorate, and besides all this, the Directorate of Moroccan Affairs believed the conversions were "almost always fake." 67 It is difficult to ascertain the real motives of those who converted since there are no testimonies of Moroccan veterans who had converted. These religious transformations were still an issue even after the war, when a couple of conversions were recorded, like one in Cordoba. In March 1941 the Bureau of Moroccan Affairs commented on the case of Mohammed El Uariachi, who was expelled from Spain after the war; he returned and managed to stay by being baptized and marrying a Spanish woman. The bureau commented that the majority of such cases revolved around "opportunistic people." It is safe to say, however, given the relatively few cases mentioned, that those conversions were certainly not significant enough to have an impact in Spanish Morocco or on the army fighting in Spain.

\section{Hospitals}

The one place where Muslims and Christians interacted most was in military hospitals. There, Moroccan soldiers fell in love with Spanish women, priests tried to win new souls for Christianity, complaints on religious matters were made, and compromises were reached. A military hospital was almost the only place for Moroccan soldiers to get to know Spanish society, or at least its Nationalist version.

If the testimonies of the surviving Moroccan veterans are any indication, then a very large segment of the Moroccan combatants in Spain stayed for short or long periods in the Spanish military hospitals. There is scarcely a soldier who was not wounded in battle and sent to recuperate in the military hospitals of Spain. But within months of the start of the war, wounded Moroccans were hospitalized in separate spaces, usually separate wards in the same hospitals. Gradually, the Nationalists founded separate Muslim hospitals all around Spain, to accommodate the presence of Moroccan units in all theaters of operation. ${ }^{68}$ Late in the war, the Muslim hospital in Zaragoza grew to be the

67 AGA, Af, 81.1113, Cp 3: letter, 20 May 1938.

68 In the spring of 1937 hospitals of signicant size for the Moroccans were located in Zaragoza, Burgos, Valladolid, Caceres, Coruña, Almendralejo, Zafra, Cordoba, Sevilla, Jerez de la Frontera, Cadiz, Huelva, Medina del Campo, Plasenca, Villablanca, Ronda, and Puerto de Santa Maria, among others. At the time beds per hospital varied between 225 
most prominent one. In such hospitals on the peninsula, care was taken to provide Muslim a diet for the wounded, ${ }^{69}$ and to distribute the tables for prayers times. ${ }^{70}$ For the entertainment of the inmates there were Moorish cafés. Even storytellers were sent to the hospitals to "mitigate the torment of these wounds." ${ }^{\prime 1}$

As the presence of Muslim hospitals in Spain had no precedent in recent times, and certainly not on such a large scale, some problems and complaints arose at the beginning because of the lack of an established organization to provide for Islamic dietary needs, of organized religious personnel, of rules of communication and so on. In November 1936 the army inspector Cabanellas complained to Franco about what he saw in some "Muslim" hospitals that he visited. In addition to his disapproval of proselytizing attempts in the hospital he remarked that some patients were deceived into believing that the meat they were served was slaughtered according to Muslim rites, only to discover later that this was not the case, leading some to refrain from eating for days. ${ }^{72}$ Such complaints led to individual efforts to correct the situation and, in 1937, the Moroccan authorities and the Spanish Nationalists organized their efforts to adapt the hospitals to make them a more Islamic environment and ensure that the stay of the wounded was a pleasing one. This adaptation effectively meant the creation of a separate Moorish space.

In March 1937 the Moroccan vizier Ben Ali visited Spanish hospitals, whereupon he wrote a letter suggesting the establishment of separate Muslim hospitals in the rear lines. He suggested that the wounded be quartered separately according to their military affiliations: the Regulares separately from the Mehal-las. The vizier also suggested a Moorish staff consisting of, first, a faqih (cleric) who would be charged with the duties of the Imam, butcher, notary, and undertaker; second, a raqqās whose duties were to carry letters and money to the soldiers' families in Morocco; and third, an interpreter. Among other suggestions, like the establishment of ablution and prayer halls and a burial place, Ben Ali suggested that each town with a Muslim hospital establish an "Arab café" for the Muslim wounded. In that case, he continued, the Muslim

and 400, with the possibility of an additional 200 beds in Zaragoza and 300 in Medina del Campo. See Agmav, A.2, L.19o, Cp 12/6 and AgAmV, A.2, L.19o, Cp 14/1.

69 AGA, Af, 81.1122, Racionado para moros hospitalizados. 31 December 1937.

70 See examples in AGA, Af, M.1685, L.2963.

71 AGA, Af, 81.118o, Proponiendo el envío a España de narradores de cuentos para que recorran los Hospitales para marroquíes allí instalados. 28 December 1937.

72 Cabanellas to Franco, 19 November 1936, AgAmv, A.1, L.59, Cp 86. 
wounded would be prohibited from entering "foreign cafés so that they would not have forbidden drinks. For that, a special vigilance must be appointed." ${ }^{\prime 3}$

In the requests of the Moroccan minister we see an attempt to exercise some control on the lives of Moroccan subjects in Spain, by limiting the contact of Moroccan soldiers with the surrounding Spanish environment and preventing its perceived corrupting influence, like drinking alcohol. The High Commissariat had already, in February 1937, preceded the Moroccan minister by issuing instructions on the organization of Moroccan hospitals in Spain. The religious staff was larger than that suggested by the minister. It consisted of an Imam, chief of the religious staff, who also functioned as a notary, a mudarris (teacher) to answer religious questions, a kātib (writer) to write letters to the soldier's families, and a munazif al-mawta (cleaner of the dead) who was responsible for the burial preparations. These were assisted by two cooks who were also butchers, as well as four assistant cooks, plus two couriers to attend to the injured and handle inheritance matters of the deceased, in addition to an interpreter. As for general hospitals with "Moroccan departments" the staff varied according to the number of wounded present. ${ }^{74}$

The general staff in Salamanca was in agreement with much of the minister's request and especially with regard to the prohibition of Moroccan soldiers visiting European cafés. It cited as an extra reason the fear of espionage and the necessity of avoiding incidents which had been "unfortunately frequent" in towns where many natives were present. ${ }^{75}$ In February 1937 Franco had also already referred to "Moorish cafés" which would provide the wounded soldiers with a place that had a "familiar" environment. ${ }^{76}$ It seems that the prohibition of selling alcohol to Muslims did not meet with equal success everywhere. A report, in March 1938, on drunken Moroccan inmates, lamented the absence of such a prohibition in the southern town of Jerez de la Frontera. ${ }^{77}$ In March 1938, Salamanca suffered from the same problem: the local authorities would not prevent sales of alcohol to the Moroccan inmates of the military hospital there and this led to the intervention of Moroccan military police to stop the "scandals of the Moors." ${ }^{\text {" }}$ But hospitals were not allowed to actually forbid

\footnotetext{
73 AgmaV, C.2396 A.2, L.19o, Cp 14. Letter in Arabic.

74 AgMAV, C.2396 A.2, L.19o, Cp 14. Instrucciones para la organización de los hospitales instalados en la península, destinados a marroquíes. 28 February 1937.

75 Agmav, C.2396 A.2, L.19o, Cp 14. Report by the General Staff, 19 March 1937.

76 AGAMV, A.1, L.35, Cp. 20.

77 AGA, Af, 81/1179, Varios hospitales.

78 AGA, Af, 81.1180, Intervención del norte to Sanchez Pol, 10 March 1938.
} 
ambulatory Moroccan inmates from taking strolls outside the hospital. In a report in March 1937, Moroccan soldiers in a Salamanca hospital complained that they were not allowed out, nor were their visitors allowed in; this led the commander of the army of the north to instruct this hospital not to forbid the inmates from taking walks outside the premises. ${ }^{79}$

Despite the care the Nationalists took to respect the religious sensitivities of their Moroccan soldiers, complaints in this regard still arose. Sometimes the reason for these grievances was the behavior of the Moroccan religious personnel themselves. Excessive alcohol drinking, continuously shaving their own beards, or failing to lead the prayers were reasons given in a number of complaints about these fuqaha $\bar{a}^{\prime}$ (pl. faqih). ${ }^{80}$ Similar complaints about drinking were occasionally also filed against members of the native military police who were atttached to military hospitals. ${ }^{81}$ These complaints seemed, however, not as grave as failing to perform duties towards the dead, or even flatly refusing to handle these duties because the dead did not deserve them.

When complaints related to religion arose in hospitals the Nationalist authorities strived to investigate and verify. One hospital about which repeated complaints were made was the one in Villafranca de los Barros (Badajoz province). The complaints against the director of the hospital revolved around the presence of religious (Christian) images, the lack of a separate kitchen for the Muslims, and the lack of a separate space within the same kitchen (i.e., the same utensils were used for Spanish Christians as for the Moroccan Muslims), the refusal of the director to provide transport for the burial of the dead, the existence of a "bar" inside the hospital, etc. ${ }^{82}$ Upon investigation the complaints were found to have been exaggerated: the religious images were all covered, except one in a hall that the inmates were forbidden from entering; the Europeans cooked and used their utensils in a separate space in the kitchen and plans were made for an independent kitchen; the burial transport problem was a one-time incident that resulted from maintenance problems; and in fact not all the Muslim religious personnel agreed with the content of the complaints. The investigation recognized, however, that the director of the hospital

79 Agmav, A.1, L.50, Cp. 17. Instructions on 20 March 1937; report by the HQ of the Generalissimo on 12 March 1937.

8o AGA, Af, 81.1122, letter of complaint nr. 3159, 9 January 1939.

81 For complaints about gambling and failing to observe Ramadan against one such mejasni, see AGA, Af, 81.1187, letter to the inspector of the Moroccan mejasnia, 1 December 1937. In this case, however, it was fellow policemen who complained about his failure to fast.

82 AGA, Af, 81.1179, Leg, 3963. Zaragoza, letters on 9 January 1939; 31 December 1938; 15 December 1938. 
was not quite amiable. ${ }^{83}$ This shows, if anything, the extent to which the Nationalist military authorities were prepared to accommodate the sentiments of the Moroccan soldiers, and the privileged position these soldiers (and the Muslim clerics) had in imposing their own lifestyle and wishes in hospitals in a country in which they were foreigners. It is remarkable that the archival material does not show complaints, on the Spanish side, about these Moroccans who dared act more like hosts than guests.

Regardless of the occasional complaints and the initial problems, surviving veterans record mostly positive memories of the hospitals; they recall them with nostalgia. "The food was good, the beds were changed daily. The daughters of generals and officers, and the sons of merchants and doctors did that. They were polite" remembers one who worked there. ${ }^{84}$ "The hospital of Seville was very nice. A delegation of Moroccan $q \bar{a} i d s$ and bashas [tribal leaders and high city officials] visited us. So we were given plenty of clothing and food." ${ }^{85}$ The old nurses were remembered affectionately. "The nun there [in the Salamanca hospital] was very nice to me and used to call me son." ${ }^{86}$ Such are the majority of the memories of the stays in the military hospitals. It is possible that the passage of decades have filtered out any memories of discomfort or the occasional irritation, but such consistently positive memories coupled with the documentary evidence of the hospital policies of the Nationalists lead to the conclusion that the military succeeded to some degree in establishing a home-like environment, or a little Morocco for its wounded Moroccan men, though it did not always manage to keep them in there.

\section{The Sinners}

For all the attention the Nationalists gave to the religious sentiments of the Moroccan soldiers, and for all the efforts to portray them as God-fearing pious soldiers, many of these young men do not seem to have been particularly pious Muslims. There is no way to quantify those who fulfilled the profile of observant Muslims as opposed to those who did not. As we have seen, some hospitals struggled with the issue of Moroccan convalescents who caused

\footnotetext{
83 Ibid.

84 Testimony of Abdelsalam ben Hussein. He was a kātib (writer/notary) in one such hospital. El Merroun papers.

85 Testimony of Abdel Nabi ben Omari. El Merroun papers. He adds: "Those Bashas and dignitaries walked among our beds and told us to be men and [be] patient and to fight."

86 Interview with Al Hussein ben Abdessalam. Ceuta, January 2011.
} 
"scandals" connected to alcohol drinking. The documentary and oral evidence seem, however, to demonstrate that among the Moroccan soldiers who fought in Spain, those who observed prayers, abstained from drinking alcohol, and fasted were in the minority. "Most of them were not religious" remembers one veteran. ${ }^{87}$ In the whole company of another one, only one member performed the prayers, though they all fasted in Ramadan. ${ }^{88}$ Alcohol was often consumed. ${ }^{89}$

The Moroccan soldiers also engaged in sexual relations with Spanish prostitutes upon their arrival in Spain, ${ }^{90}$ and this sometimes led to brawls with Spanish soldiers. ${ }^{91}$ And they were not always welcomed by these prostitutes. ${ }^{92}$ This was, perhaps, one reason the Spanish military arranged, early in the war, for Moroccan prostitutes, as well as dancers and singers who doubled as prostitutes, to be shipped to Spain and quartered near Moroccan units where they exclusively serviced the needs of these units. ${ }^{93}$ It also happened that, during hard times and because of a lack of food, Spanish women exchanged sexual favors with Moroccan soldiers in exchange for food. ${ }^{94}$

If many Moroccan soldiers proved not to be practicing Muslims when it came to performing prayers, drinking alcohol or visiting prostitutes, they were, at least, somewhat more enthusiatic about fasting the month of Ramadan.

$87 \quad$ Interview with Abdellah Abdekader. Nador, July 2011.

88 Interview with Kendoussi Bu Midyen, Nador, July 2011.

89 Interview with Mohamed Abdallah Susi, Ceuta, January 2011. See also Balfour, Deadly Embrace, 283 .

$90 \quad$ Antonio Bahamonde y Sánchez de Castro, Un año con Queipo, memorias de un nacionalista, (Barcelona: Ediciones españolas, 1938), 28.

91 For examples of quarrels at prostitution houses between Moroccan and Spanish soldiers see AGA, Af, 81/1125, Leg. 3770, escándalos—reyertas. In one such incident, a Moroccan military policeman was beaten up by a Requeté and a Legionnaire. The madam of the house claimed that he had mistreated one of the prostitutes while he accused the two Spanish men for attacking him without reason. While being interrogated he threatened to take revenge on the madam for testifying against him.

92 J.R. Saiz Viadero, Conversaciones con la Mary Loly: 40 años de prostitución en España (Barcelona: Ediciones 29, 1976), 18.

93 AGA, Af, 81.1150, Exp.5429; Letter on 12 September 1938, AGA, Af, 81/1125, Leg.3370, Cp 2 Varios; Agmav, A.1, L.5o, Cp. 45. See also the report by a Republican spy: Servicio de Información Exterior, December 1937, in International Institute for Social History, Archivo FAI, CP, 33A/5.

94 Testimony of Ihmido El Ma'dani. El Merroun papers. The witness recalls that women in Barcelona, upon its fall, called on Moroccan soldiers to sleep with them "for there was hunger." 
Fernando Fernández de Córdoba, a famous radio announcer for the Nationalists during the war, related that one evening in 1936 near Valdemoro (south of Madrid) the "Moors" suddenly started to fire continuously in the air, creating a tense situation that confused Spanish troops nearby until the head of the Moorish unit resolved it by explaining that Ramadan had begun. According to Córdoba, these "infantile and simple men," believed that "the first one to fulfill the ritual of firing his rifle will gain a place next to Allah." ${ }^{95}$ Whether the majority of the soldiers fasted during actual combat operations is a question in need of clarification. But it seems that in times and places when and where the troops were recuperating or resting most of the troops either observed the fast or at least refrained from breaking it out of fear of the judgment of other soldiers. ${ }^{96}$ It seems that there was a greater tendency to reprimand those who did not fast than those who did not perform prayers. ${ }^{97}$

It would seem that the majority of Moroccan soldiers who fought in Spain, rather than being the devout Muslims the Nationalists portrayed them to be, were in fact men prone to "sinning," and they only selectively observed their religion at other times.

\section{Conclusion}

Religion was important in the way the Spanish Nationalists viewed, presented, and treated their Moroccan troops. In a Cruzada against those accused of antireligion, religiousness was the raison d'être for the presence of these troops in Spain, at least in terms of the justification of their use. The presence of Italians or Germans could not be justified in those same terms. Faith, i.e., belief in an established organized religion, was the only binding element that could be argued. Therefore, the Moroccans, in their participation to create a traditional Spain, had to be religious or at least be presented that way. But this was not just a temporary and practical matter. The image of the religious Moroccan fit the standard stereotype the Spanish had of the Moors: at times he was presented as a "fanatic," at other times as "deeply religious," two terms that referred to two sides to the same coin.

\footnotetext{
95 Fernando Fernández de Córdoba, Memorias de un soldado locutor (Madrid: Ediciones Españolas, 1939), 109-110.

96 Testimony of El Siddiq El Kumeili. El Merroun papers.

97 AGMav, A.1, L.50, Cp. 17. Instructions on 20 March 1937; report by the HQ of the Generalissimo on 12 March 1937.
} 
The Spanish Nationalist military sought to maintain a separate religious space for its Muslim soldiers. The Muslim hospitals, cemeteries, the Muslim diet, the prohibition of Christian proselytizing among Muslim troops, etc., were all part of this separate religious space. In some cases it was the Moroccans who sought it, whether these were soldiers or visiting native officials. This was, therefore, a policy that was initiated and approved by both the Spanish and the Moroccan sides.

The motives for such policies suggest a question: Did the Spanish Nationalist military conduct these policies and establish separate religious spheres out of a genuine respect for the faith of its Muslim soldiers? Regardless of whether the respect for the faith itself existed and was genuine, the concern for the religious feelings of the Moroccan troops is clear from the many documents and reports that touch on the matter and therefore must be considered genuine. These documents do not show any cynicism on the part of the Spanish military with regard to the religious feelings of the Moroccan soldiers. Treating their Moroccan soldiers well, also in matters of faith, ensured that Spanish officers could obtain the best from them. It was also politically important to ensure stability and the continuing support of the Spanish protectorate. It seems, however, that the religious policies were not only a matter of protecting the spiritual space of the Moroccans, or pleasing the Moroccan authorities. The rejection of the idea that a conversion to Christianity could ever be a genuine one, the presentation of the Moroccans to both the Spanish people and to the world as deeply religious and spiritual, and the establishment of a traditional Spain reminiscent of the medieval one meant that the Moroccan soldiers in Spain had to be Muslim and had to be religious whether they liked it or not.

It is appropriate to finish this chapter with a curious story that illustrates the complexities of the religious issue of the partly Islamicized Spanish military. In the 1950s Mohammed Amazyān, the only Muslim to attain the rank of general in the Spanish army, was appointed Captain General of Galicia; in his new position he had the duty of conducting a yearly traditional honor, in the name of the head of state, towards the apostle Saint James of Compostela, known as Santiago Matamoros (Santiago the killer of the Moors). It is said that, to avoid an embarrassing situation, flowers or a blanket were used to cover the parts of the statue which show the holy apostle crushing the Moors, so as not to offend the general. ${ }^{98}$ Such were the ironies of the holy war. 


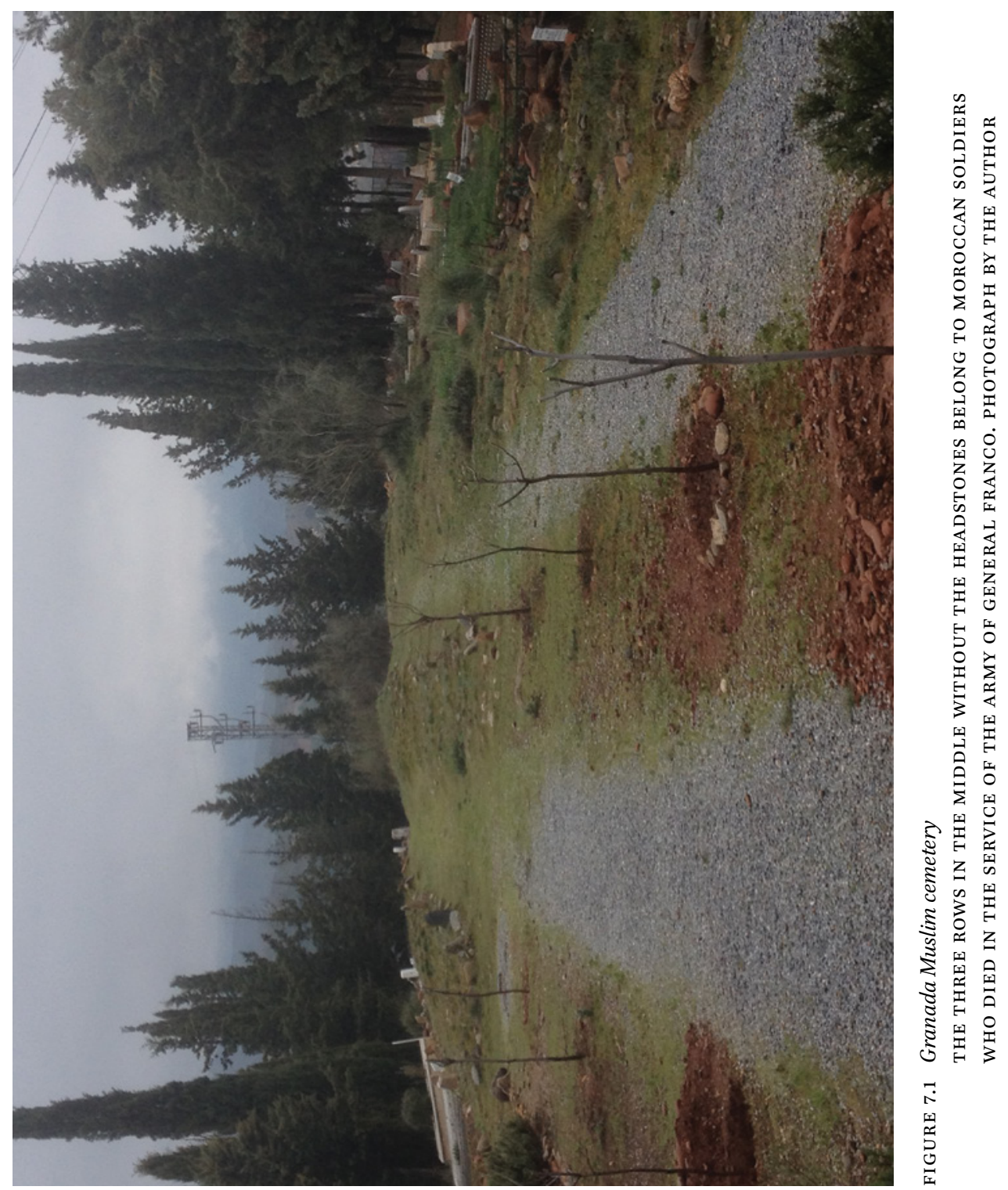




\section{Bibliography}

ABC Sevilla. "Marruecos: Covadonga de la actual reconquista." 17 July 1938.

Albet-Mas, Abel. "Three Gods, Two Shores, One Space: Religious Justifications for Tolerance and Confrontation between Spain and Colonial Morocco during the Franco Era." Geopolitics 11, no. 4 (2006): 580-6oo.

Asín Palacios, Miguel. "Porqué lucharon a nuestro lado los musulmanes marroquíes." In Miguel Asín Palacios: Obras escogidas II y III de historia y filología árabe. Madrid: Viuda de Estanislao Maestre, 1948.

Bahamonde y Sánchez de Castro, Antonio. Un año con Queipo, memorias de un nacionalista. Barcelona: Ediciones españolas, 1938.

Balfour, Sebastian. Deadly Embrace: Morocco and the Road to the Spanish Civil War. Oxford: Oxford university press, 2002.

Choukri, Mohamed. al-Khubz al-ḥäfi. Casablanca: Le Fennec, 2010.

Cockburn, Claud. Cockburn in Spain: Despatches from the Spanish Civil War. London: Lawrence and Wishart, 1986.

Corral Castanedo, Antonio. Esta es la casa donde vivo y muero. Valladolid: Ateneo de Valladolid, 1992.

Diario Marroqí. "Los aviones rojos bombardean la Mezquita de Córdoba." 19 August 1936.

Fernández de Córdoba Fernando. Memorias de un soldado locutor. Madrid: Ediciones Españolas, 1939 .

Fleming, Shannon E. "Spanish Morocco and the Alzamiento Nacional, 1936-1939: The Military, Economic and Political Mobilization of a Protectorate." Journal of Contemporary History 18, no. 1 (January 1983): 27-42.

Frasier, Ronald. Blood of Spain: An Oral History of the Spanish Civil War. New York: Pantheon Books, 1979.

García Figueras, Tomas. Marruecos: La acción de España en el Norte de África. Madrid: Ediciones Fe, 1944.

Hakim, Mohammed Ibn Azzuz. La actitud de los moros ante el alzamiento: Marruecos 1936. Malaga: Algazara, 1997.

Keen, Judith. Fighting for Franco: International Volunteers in Nationalist Spain during the Spanish Civil War, 1936-1939. London: Leicester University Press, 2001.

Llordes Badía, José. Al dejar el fusil. Memorias de un soldado raso en la guerra de España. Barcelona: Ediciones Ariel, 1969.

Madariaga, María Rosa. Los moros que trajo Franco. La intervención de tropas coloniales en la guerra civil española. Barcelona: Ediciones Martínez Roca, 2002.

Merroun, Mustapha El. Las tropas marroquíes en la Guerra Civil española. Madrid: Almena ediciones, 2003 .

Mesa, José Luis de. Los Moros de la Guerra Civil Española. Madrid: Actas, 2004 
Payne, Stanley G. The Franco Regime 1936-1975. Madison: University of Wisconsin Press, 1987.

Powell Fox, Rosalinda. The Grass and the Asphalt. Puerto Sotogrande: J.S. Harter and Associates, 1997.

Ribeiro de Meneses, Filipe. Popularizing Africanism: "The Career of Víctor RuizAlbéniz, El Tebib Arrumi." Journal of Iberian and Latin American Studies 11, no. 1 (April 2005): 39-63.

Ruiz Albéniz Víctor. Las cronicas de El Tebib Arrumi, Tomo II, Campañas del Jaramay el Tajuña. Valladolid: Librería Santarén, 1938.

Saiz Viadero, J.R. Conversaciones con la Mary Loly. 40 años de prostitución en España. Barcelona: Ediciones 29, 1976.

Sánchez Ruano, Francisco. Islam y Guerra Civil Española, Moros con Franco y con la República. Madrid: La esfera de los libros, 2004.

Sullivan, Brian R. "Fascist Italy's Military Involvement in the Spanish Civil War." Journal of Military History 59, no. 4 (October 1995): 697-727.

Thomas, Hugh. The Spanish Civil War. New York: Modern Library, 2001.

Unidad Marroquí. "La guerra ha terminado. Marruecos confía en la palabra del caudillo de España." 3 o March 1939. 


\title{
Muslims of Interwar Lithuania: The Predicament of a Torn Autochthonous Ethno-Confessional Community
}

\author{
Egdūnas Račius
}

\section{Introduction}

Though various aspects of the history of the Muslim presence, which stretches for more than six hundred years, in the territory of what once was the Grand Duchy of Lithuania (GDL), have been studied rather extensively, mainly in Polish historiography but also in that of Lithuania and Belarus, one particular period seems to have escaped the attention of historians. It is the interwar period, the time of the first Lithuanian Republic between 1918 and 1940. A contemporary Polish historian Stanisław Kryczyński in his otherwise seminal study from 1938, Tatarzy litewscy. Próba monografii historyczno-etnograficznej (Lithuanian Tatars. An attempt at historic-ethnographic monograph), barely mentions the situation of Tatars in the Republic of Lithuania at the time. ${ }^{1}$ It took over fifty years for the first scholarly article on the interwar Lithuanian Tatar community to appear in Lithuanian. ${ }^{2}$ Practically all other publicly available information on that period has come in the form of memoirs of Tatars themselves published in their monthly Lietuvos totoriai (Lithuanian Tatars) over the past fifteen or so years.

The absence of interest among historians in the life of the Muslim community in interwar Lithuania can partially be explained by its numerical and consequently socio-political, let alone economic, insignificance in the general life of the Lithuanian nation in that period-Lithuanian Tatars, who made up the bulk of the Muslim community in the country, had never posed any political or social challenge to the state or society to be placed on the radar of either politicians, media, the powerful and seemingly omnipresent Catholic Church, or

1 Stanisław Kryczyński, Tatarzy litewscy. Próba monografii historyczno-etnograficznej (Warsaw, 1938).

2 Tamara Bairašauskaitė, "Musulmonų konfesinė bendruomenė nepriklausomoje Lietuvoje," Lietuvos istorijos metraštis 1991 (1993). 
local scholars and intellectuals, for that matter. ${ }^{3}$ However, the main reason for the present lack of interest in the study of the interwar Muslim community in Lithuania may actually lie in the unavailability of sources (in the form of verbal material) for research.

Therefore, like Bairašauskaitè's article of more than twenty years ago, the current text relies heavily on the same available archival material, consisting of several hundred individual documents kept in the Lithuanian State Archive. Though this material, chiefly comprising written communication between, on the one side, state institutions, and on the other side, the Tatar congregations and individual Tatars, does not provide a comprehensive picture of the (religious) life of Lithuania's Muslim Tatars in the interwar period, it nonetheless allows a glimpse into the internal structures and dynamics of relations in the community as well as the congregations' positions vis-à-vis the state and the wider society. The available material also allows one to gain an insight into how the state (in the person of relevant institutions) perceived and treated the community. Ultimately, the interwar period is a (largely missing) connecting link between the centuries-long presence of Muslim Tatars in the territory of the former Grand Duchy of Lithuania prior to the emergence of sovereign modern nation-states in that territory and the present situation. These precious few documents from the period that have been preserved deserve to be made public both to the Lithuanians who themselves know very little about the Tatar history in the country and to outside readers who because of natural obstacles like the language of the documents and their relative inaccessibility (the documents have not been digitalized and are available only on request and in person at the State Archive) have even less opportunity to familiarize themselves with this aspect of, indeed, European history.

Though, admittedly miniscule in absolute numbers, the Muslim community of interwar Lithuania is nonetheless part and parcel of the broader European and indeed global history. Along with the Polish and Byelorussian Muslim communities, the Lithuanian Tatar Muslim community during that time can be regarded as a sort of link between, on the one hand, the more established, albeit rapidly declining and increasingly weaker Muslim communities in the

3 This is, in a way, attested to by the fact that the Lithuanian print media of the interwar period ran only a handful of articles, interviews, and reports on Lithuania's Muslim community. See the digital archive of the Lithuanian print media, Lithuanian Cultural Heritage in the Virtual Environment, at http://www.epaveldas.lt/vbspi/content/about.jsp. 
Tatar ancestral lands in Eastern Europe (in the Soviet Ukraine and Russia, and Crimea in particular) and, on the other hand, western Europe, where Muslim communities were just beginning to form. The Lithuanian Tatar community shared both the memories of where they came from and a feeling of loyalty to and belonging in Lithuania.

The main aim of the chapter is to reveal the process and consequences of the identity change in the Tatar Muslim community in the territory of the interwar Lithuanian nation-state as they are captured in the formal communication between the communities and state authorities. The chapter also shows how closely the Lithuanian Muslim community's public expression of identity through rhetoric and behavior correlated with (or even depended on) the official state stance and policies toward the neighboring nation states, in this case Poland. It further illustrates how the once single Muslim community of the former Grand Duchy of Lithuania, because of certain geopolitical circumstances (like the emergence of nation states), mutated into several separate, even antagonistic, national Muslim communities, which, when given a chance, refused to re-unite. This birth of new national identities among Tatars of the former Grand Duchy of Lithuania is well worth a deeper analytical look as it contributes to a wider picture of identity changes and identity building among Muslims in interwar Europe. In this regard, the Lithuanian (and arguably Polish as well as Byelorussian) Tatar case is an alternative to the otherwise stereotypically perceived process of integration and indigenization of Muslims in Europe, then and now.

In most historiography, the Tatars of the Grand Duchy of Lithuania are referred to as 'Lithuanian Tatars,' as opposed to Crimean and Kazan Tatars. In the interwar period, however, next to this historical title, new ones appeared that reflect the political reality of the new nation-states. So, Tatars in Poland came to be called 'Polish Tatars,' while those living in the Soviet Republic of Byelorussia were called 'Byelorussian Tatars.' In this article, the designation 'Lithuanian Tatars' primarily means those Tatars who were living in the territory of the sovereign interwar Lithuanian state. Furthermore, since the overwhelming majority of Lithuania's Muslims in that period were ethnic Tatars, and virtually all Tatars were (at least nominal) Muslims, the titles 'Tatars' and 'Muslims' (and consequently 'Lithuanian Tatars' and 'Lithuanian Muslims') in this article are treated as synonyms and used interchangeably.

While interwar Lithuanian Tatars called their local religious communities 'parish' (parapija), in this article they are called 'congregations;' the term 'community' is used only when applied to Lithuanian Muslims in toto. 
The history of Islam in Lithuania dates back to the fourteenth century when the first migrants - political refugees - from the Golden Horde (and later, the Crimean Khanate) came to the Grand Duchy of Lithuania. Soon they were joined by new arrivals, consisting chiefly of mercenaries hired by Lithuanian grand dukes, more refugees, and prisoners of war who, once freed, chose to stay. The immigrants, the majority of whom were recently Islamized Turkic speakers (Tatars), eventually settled in the northwestern parts of the Duchy, mainly in village communities around the capital Vilnius. Arguably, the choice of settlement area was deliberate on the side of the Lithuanian rulers-Tatars were settled on the monarch's lands close to the seat of power, so they could be accessible and available whenever needed.

Despite or because of the fact that Muslims have been only a tiny minority of the citizenry of the Duchy (though precise data are not available, it can be safely assumed that at no time in history did the Muslim population of the GDL exceed 100,000 souls), they enjoyed almost all the rights and freedoms that their Christian fellow citizens did. Upon settlement, the Tatar elite were granted ranks of nobility and given tracts of land to be used as fiefs that later became their personal possessions. Even more, the Muslims in the Grand Duchy of Lithuania (and later, post-1569, in the Republic of Two Nations) were never forced to abandon their faith either through coerced conversion or because of artificially created obstacles in practicing their religion (such as bans, prohibitions, segregationist decrees, etc.). In the GDL/the Republic of Two Nations, Muslims throughout the centuries, with a few brief exceptions, were allowed to publicly observe practically all Islamic duties and rituals.

It is believed that mosques on the then territory of the Grand Duchy were being built as early as the late fourteenth or beginning of the fifteenth century. ${ }^{4}$ In the times of the Republic of Two Nations (that is, until the final partition in 1795) there might have been up to two dozen mosques, ${ }^{5}$ usually with adjacent cemeteries. These mosques were apparently run by local communities with little if any outside interference. The congregation as an independent body would choose its own religious leaders-mullas (formally called imams). Though the level of erudition and education of those mullas is impossible to assess (and there are indications that it has never been high, as many of them were not even capable of reading Arabic, and the first ever translation of the

4 Stanislovas Kričinskis, Lietuvos totoriai (Vilnius: Mokslo ir enciklopedijų leidykla, 1993), 158.

5 Ibid., 161. 
Qurān into Polish, the lingua franca of the time among at least the educated local Tatars, publicly appeared only in 1858), in the absence of any institutionalized religious hierarchy and formalized religious education, they appear to have been (the sole) spiritual guides for Muslims of the GDL and later the Republic of Two Nations. In general, throughout the history of Lithuanian Muslims, mullas were highly respected as, next to their spiritual and ritual functions, they were frequently among the few literate and therefore they took charge of administrative affairs within the community; sometimes they even performed the function of safekeeping the personal treasures of members of their congregations. ${ }^{6}$ Throughout the times of the Grand Duchy and the Republic of Two Nations (i.e., between the fourteenth and eighteenth centuries) Muslims retained their religious autonomy from both local secular and outside religious authorities, though there is sufficient evidence pointing to the Sublime Porte's interest in the well-being of the Muslims of the Republic of Two Nations. ${ }^{7}$

After the final partition of the Republic of Two Nations in 1795, most Tatars of the former Grand Duchy of Lithuania found themselves subjects of the Russian Empire and the local Tatar community was entrusted to the care of the Simferopol-based (Crimea) Mohammedan Spiritual Governing Board ("Таврическое магометанское духовное правление"), which was established in 1794 and led by a mufti. It appears, however, that the Muslims of the lands of the former GDL vehemently insisted on retaining their religious independence. For instance, it is reported as far back as 1803 that Muslims of the northwestern territories of the empire approached the Russian government with a request not to be subjected to the authority of Russia's muftis. ${ }^{8}$ On another occasion, in a letter of 1812, they insisted on their right to choose a mulla from among themselves. ${ }^{9}$ Nonetheless, under the Statute on the Taurida Muslim Clergy promulgated in 1831 and encompassing Crimea and the northwestern territories, all ulama had to meet certain educational and competence criteria and be certified by the Spiritual Governing Board. Unfortunately, it is impossible to assess to what extent the local mullas met the set criteria. Finally, in 1851 the Russian government acceded to the Tatars' requests and officially allowed them to elect

6 Ibid., 172.

7 Dariusz Kolodziejczyk, The Crimean Khanate and Poland-Lithuania: International Diplomacy on the European Periphery (15th-18th Century): A Study of Peace Treaties Followed by an Annotated Edition of Relevant Documents (Leiden: Brill, 2011).

8 Tamara Bairašauskaité, Lietuvos totoriai XIX amžiuje (Vilnius: Mintis, 1996), 130-131.

9 Kričinskis, Lietuvos totoriai, 168. 
mullas from among themselves, though they still needed to be certified by the Spiritual Governing Board. ${ }^{10}$ An attempt by some local Muslims in the middle of the nineteenth century to convince the Russian government to establish a separate spiritual governing body (muftiate) for the Muslims of the western provinces, however, failed miserably.11

In the end, the fact that the headquarters of the formal religious authority, the Spiritual Governing Board, was several thousand kilometers away, made effective communication (and control) practically impossible and the real authority of the generally very reluctant Crimean muftiate over the Tatars in the northwestern territories of the empire remained tenuous and minimal until the end of Russian rule in Lithuania during World War I. Ultimately, Russian authorities' designs and desires to use muftiates in the form of spiritual boards established from above, as tools to control the empire's Muslim subjects had little practical outcomes in regard to Tatar Muslims in the lands of the once Grand Duchy of Lithuania; they survived as an insular community of interrelated but independent congregations into the twentieth century.

\section{Muslims in Interwar Lithuania: The Distribution and Visibility}

In early 1918, in view of the inevitable end of World War I the national(ist) elite in Vilnius (then German-occupied Lithuania) proclaimed its independence, though the definitive formation of a sovereign state took shape several years later after all adversarial forces were finally repelled and the borders of the new state were secured. This was the first time that a Lithuanian nation-state was founded and a Lithuanian nation with the titular Lithuanian ethnicity came into being. Hitherto, ethnic Lithuanians were either a political or a statistical minority in the consecutive state formations they were living in. As was common elsewhere in Europe at the time, the birth of a nation and a nation-state went hand in hand in Lithuania too. ${ }^{12}$ All other ethnic groups living in the territory of the

10 Высочайше утвержденное мнение Государственного Совета 8 января 1851 г. об избрании мулл в магометанских обществах Западных Губерний [The opinion of the State Council of 8 January 1851 on the election of the mullahs in Mohammedan communities of the Western Provinces approved by His Majesty], at http://constitutions.ru/ archives/3239, accessed 10 April 2011.

11 Bairašauskaitè, Lietuvos totoriai, 138-139.

12 For more on the birth of the modern Lithuanian nation and the state, see Alfred Erich Senn, Lithuania Awakening (Los Angeles: University of California Press, 1990). 
new state had to define their relation with the state and titular ethnicity and thus profoundly redefine their identity. This was as true of Jews, Karaims, Poles, Russians, Germans, as of Tatars, especially the Muslims among them. ${ }^{13}$

As has been indicated above, the bulk of the Lithuanian Tatars had traditionally been living in the vicinity of Vilnius, the historical capital of the Grand Duchy of Lithuania - this is where they were given land by the Lithuanian rulers and where they founded their villages. In the aftermath of World War I, in 1920, the region of Vilnius was, however, occupied ${ }^{14}$ by Poland and most of the 'Muslims of the GDL' (some six to seven thousand ${ }^{15}$ ) became Polish citizens. Under Polish rule, Vilnius (Pol. Wilno) became the spiritual and cultural center of the Muslims of the newly established Polish Republic. It is there that an official Muslim organization, the Muftiate, whose purpose was to unify some two dozen Muslim congregations scattered around Poland under one representative institution and thus gain bargaining power vis-à-vis state authorities and other faith communities, was finally founded at a convention of delegates of Muslim congregations in late 1925. Dr. Jakub Szynkiewicz, a graduate of Berlin University, who was well versed in Islamic studies and spoke both Arabic and Turkish, was elected the first (and, as it later turned out, until World War II, the only) mufti of Muslims living in the territory of the newly independent Polish state. The fact that Szynkiewicz was not a classical alim but a Europeaneducated orientalist appears not to have prevented the congregations from electing him mufti and, in the absence of other promising candidates, actually made him the only suitable nominee. Moreover, Szynkiewicz appears to have been the only one of his kind not only among the Muslims of Poland but also among all the Tatars in the territories of the former GDL- there was no one of similar stature in either the Republic of Lithuania or Soviet Byelorussia. This naturally made Szynkiewicz the only "proper" authority among Polish Muslims at least until several younger Tatars were sent to study at al-Azhar in Egypt.

13 A number of Tatars converted to Christianity in the nineteenth century and consequently they and their progeny ceased to be considered by the Tatar Muslims as Tatars. Consequently, most of such non-Muslim Tatars eventually began to identify with one of the larger local ethnic groups-Russian, Polish or Lithuanian. For this aspect of the changes in Tatar identity, see Bairašauskaité, Lietuvos totoriai XIX amžiuje, 171-181.

14 The Polish administration of the city of Vilnius and its region between 1922 and 1939 was at the time and is still considered by the Lithuanian state as an act of occupation. Lithuania remained in a state of war with Poland until 1938, when diplomatic relations were finally established but tensions between the states remained.

15 Ali Miskiewicz, Tatarzy polscy 1918-1939. Zycie spoteczno-kulturalne i religijne (Warsaw: PWN, 1990), 58-6o. 
Meanwhile, in comparison, imams in independent Lithuania throughout the interwar period remained self-taught.

The Muftiate actively participated in drafting and lobbying for a new law governing the relationship between local Muslim communities and the state, and in the spring of 1936 the Polish state passed this law. According to the law, communities were awarded self-rule - they had the right to elect their mullas/ imams and muazins. ${ }^{16}$ The Muftiate was thus officially recognized by the state as the representative of Poland's Muslims, in this way the Tatar community was recognized as an autocephalous faith community.

As the Vilnius region remained under Polish control until the beginning of World War II in September of 1939, the development of the Vilnius Muftiate as well as the Muslim congregations in and around the city until then can rightly be regarded as part of the history of Islam in Poland. And only between October 1939, when the region of Vilnius was given to the Lithuanian state by the Soviet Union (which was then occupying the eastern part of the former state of Poland), and the summer of 1940, when the Soviet Union finally swallowed all of Lithuania, the three Lithuanian-speaking congregations and three Polish-speaking congregations, including the one in Vilnius, were (re)united in a single state.

The 1923 census revealed that $1,107^{17}$ inhabitants of the Republic of Lithuania (excluding those possibly, though but unlikely, residing in the newly incorporated Klaipeda Region (Memelland), and, naturally, the Polish controlled southeastern part with Vilnius) identified themselves as Muslims. Of those, 1,098 were Lithuanian citizens (two Polish, seven Soviet citizens ${ }^{18}$ ). In terms of self-identification, 961 Muslims identified themselves as ethnic Tatars, ${ }^{19}$ of 146 non-Tatars 117 identifed themselves as Lithuanians (sic!), ${ }^{20} 12$ as Polish, ${ }^{21}$ one as

\footnotetext{
16 Kričinskis, Lietuvos totoriai, 170.

17 Lietuvos gyventojai: 1923 m. rugsèjo 17 d. surašymo duomenys (Kaunas: Centrinis statistikos biuras, 1925), 34 .

18 Ibid.

19 Ibid., 47.

20 Ibid., 38. It is plausible to assume that at least some, if not the majority of these 117 'Lithuanians' were in fact ethnic Tatars, who for reasons that remain unclear, chose to identify themselves as Lithuanians. If this was the case, it would be an interesting aspect of the Lithuanian Tatars' identity transformation, as it can be safely assumed that in earlier times Tatars would have been unlikely to have identified themselves as ethnic Lithuanian Muslims. It also could have been the case that some of those 117 sincerely believed that they were ethnic Lithuanians, though their origin might have been, if only partially, Tatar. 
a Turk, ${ }^{22}$ while the remaining considered themselves Russians, and five ${ }^{23}$ failed to identify their ethnic belonging altogether. There were three areas with large concentrations of Muslims in interwar Lithuania and two with smaller numbers, chiefly in the eastern and southern parts of the country. By far the largest number, $73^{2}$ in 1923, lived in villages and other small settlements in the southern Alytus district. ${ }^{24}$ The second largest, with 122 , lived in the Trakai district. ${ }^{25}$ The number of Muslims in the interim capital Kaunas and nearby villages was just a little over one hundred ${ }^{26}$ with one third (37 individuals) identifying as Lithuanians (sic!). ${ }^{27}$ There were also smaller groups of Muslims in Vilkmerge (44 persons) and Zarasai ( 56 persons) districts. The census results clearly show that the overwhelming majority of Lithuanian Tatars at the dawn of Lithuanian independence were based in rural areas with just around ten percent living in urban areas, chiefly the interim capital Kaunas.

Arguably, the most visible sign of Muslim presence (and belonging?) in an area are mosques, especially purpose-built, and cemeteries. Since the majority of the region's Tatars traditionally lived in the countryside, most of their mosques, around which religious life revolved, were situated in villages rather than cities. By the beginning of the twentieth century in the territory of the former GDL only a dozen mosques remained. Only two of the historic Tatar mosque buildings were situated in the territory of interwar Lithuania, one, built in 1889, in the village of Raižiai (Alytus district, some 70 kilometers south of the interim capital Kaunas), another, built in the 1820s, in the village of Vinkšnupiai (some $8 \mathrm{o}$ kilometers southwest of Kaunas), though this one had been damaged during World War I and reportedly remained in bad shape throughout the interwar period as there were no funds (and apparently no need) to repair it. In the city of Kaunas itself a new brick mosque (the only one of its sort in Lithuania to this day) was built on the spot of a former makeshift mosque and opened its doors to worshipers in 1932. Naturally, there were mosques in Vilnius and nearby villages (like Niemież/Neméžis, Sorok Tatary/Keturiasdešimt Totorių) but these were technically in Poland of the time.

\begin{tabular}{ll}
\hline 22 & Ibid., 48. \\
23 & Ibid. \\
24 & Ibid., 36. \\
25 & Ibid. \\
26 & Ibid. \\
27 & Ibid., 38.
\end{tabular}


Prior to the emergence of sovereign nation-states, the overwhelming majority of the 'Tatars of the GDL' throughout their history lived in one state-be it the Grand Duchy itself, the Republic of Two Nations, or the Russian Empire-and thus naturally perceived themselves and each other as belonging to the same single community, albeit dispersed over a relatively large territory. The founding of the nationalistically orientated and even mutually antagonistic independent states of Lithuania and Poland (and also of Soviet Byelorussia) almost by default obliged the Tatars to publicly redefine their identity and belonging. Even more so-members of the same families often found themselves citizens of different countries with ensuing exclusivist loyalties and allegiances, something that frequently happened also to other, more numerous, ethnic groups, like Poles, Lithuanians, Russians, and Belarusians. The most symbolic instance of this was the fate of the members of the Narutavičius/Narutowicz family, in which one brother became a signatory of the Lithuanian Independence Act of 1918, while the other brother became the first Polish president in 1922.

Those Tatars who, after all the commotion and border changing in the early 1920s, found themselves in the territory of the Republic of Lithuania, had to come to grips with the new reality — not only had they become a tiny ethnoconfessional minority in the Lithuanian nation-state, but they had also been cut off from their related congregations and their centuries-old demographic and spiritual center, Vilnius. This newly emerged factual situation demanded that the Lithuanian Tatars define their identity and relations with the outgroups (the majority society but also Tatars in the neighboring countries, foremost Poland) anew. This was made even more urgent by the seemingly permanent state of war between Lithuania and Poland over the Vilnius region; a state of war that lasted until 1938, when the two states finally established diplomatic relations. Thus, for much of the interwar period both Tatar communal relations and relations with the state authorities should also be viewed through the prism of Lithuanian-Polish relations. So, rather than lamenting the fate which had dismembered the hitherto single community with numerous intra-communal kin relations, the Lithuanian Tatars appear to have publicly expressed joy at having become inhabitants of Lithuania rather than Poland, even if the latter would have meant keeping the bulk of the Tatars in a single state. Many of the surviving documents (in the form of letters from Tatars to the Lithuanian state institutions) vividly attest to this.

In any case, it was in interwar Lithuania that for the first time in history a distinct outward Lithuanian Tatar (different from and even opposed to the Polish and Belarusians) identity was born. In their correspondence to the state 
authorities, the leadership of the Tatar congregations routinely claimed to be loyal citizens of the Lithuanian state and the nation: "in general, in the mass of the Lithuanian Mohammedans, there are no sympathies for Poland, and quite to the contrary, the Lithuanian spirit prevails, Mohammedans do well joint Lithuanian work by taking part in patriotic organizations and the union for the liberation of Vilnius, serving in the armed forces." ${ }^{28}$ In a letter dated 27 October 1939 (when the Vilnius region had already been given by the occupying Soviets to Lithuania), its authors ("a group of Lithuanian Mohammedans") argued that

Lithuanian Mohammedans are not Polish and any Polish influence needs to be eradicated and Poles are not to be given a chance to interfere in our, Lithuanian Mohammedans', faith matters. The extermination of the Polish influence will not at all harm Mohammedans because they are not Poles. In general, Lithuanian Mohammedans do not feel any sentiments toward Poland, and quite to the contrary: they, like all Lithuanians, do common Lithuanian work, participate in various organizations, serve in public offices and armed forces. ${ }^{29}$

Financial support from the state, as evident from many of the surviving documents, must have also played an important role in the Tatars' public rhetoric, especially around the time of the construction of a new mosque in Kaunas in the 1930s, as shown below.

A significant aspect of this identity construction is the Tatar adherence to the cult of Vytautas the Great, the duke who has long been regarded in Lithuania as one of the most important and praiseworthy rulers of the Duchy and who is the single most prominent figure in the Lithuanian Tatar myth of origin, which credits him with bringing the Tatars to the lands of the GDL. For instance, in a letter to the Minister of Education, dated 6 April 1930, ${ }^{30}$ in which the Tatars solicit financial assistance from the state to build a new mosque in Kaunas, arguably in commemoration of the 500-year anniversary of Vytautas' death, the authors of the letter began by paying tribute to Vytautas, whom they called "the hero, whose name is dear to us, Tatars." The authors of the letter went so far as to promise to name the new mosque after Vytautas, who incidentally was not only never a Muslim, but also appears to have remained pagan even after being christened twice as a Catholic. If, in the case of the mosque financing, one might regard the

\footnotetext{
28 391-4-1845-11.

$29391-4-1846-46$.

3о $391-4-148-2,-2 a p$.
} 
Tatar praise of Vytautas as mere rhetoric in the cause of pleasing state authorities and gaining their favor, then in a lengthy handwritten letter to the Minister of Education, dated 29 December 1939, sent by the Raižiai Tatars, their sincere admiration for Vytautas can hardly be doubted. In the letter, the authors went to great lengths to remind the minister of the long and glorious Tatar history in Lithuania by closely linking it with the person of the Grand Duke Vytautas: they claim to be "descendants of those courageous and honorable soldiers, who took part in the army of Vytautas the Great" and also that "the Lithuanian Tatars, soldiers of Vytautas the Great, out of their own free will pledged loyalty to Lithuania with their swords and to this day we stand by that pledge and honorably fulfill it. We, the Lithuanian Tatars, Lithuania's sons, are ardently attached to it." ${ }^{31}$ The authors further claim that Lithuanian Tatars, "out of respect for Vytautas the Great, mention his name in their prayers" (sic!). ${ }^{32}$ Though in the surviving archival material it is not used as an argument, it is worth noting that the historical Vytautas is reported to have been opposed to his cousin Jogaila's (Pol. Władysław II Jagiełło) marriage to a Polish princess and becoming a Polish king and thus uniting the Grand Duchy of Lithuania and the Polish Kingdom through their personal union. For this stance, in Lithuania Vytautas is almost universally held up as a defender of Lithuanian independence and contrasted with Jogaila's purported treason. In the context of animosities between Lithuania and Poland during the interwar period, this aspect of Lithuania's history was particularly stressed by Lithuanian historians of the time. ${ }^{33}$

In their correspondence to state authorities, the Tatars not only identified themselves with the Lithuanian state but also claimed to be identical with ethnic Lithuanians in all but faith: "Now we are different only in religious rituals and festivities." ${ }^{34}$ After the Vilnius region became part of the Lithuanian Republic in late 1939, even the leadership of the Vilnius-based Muslims (especially in the person of the Mufti Jokūbas Šinkevičius, his name, which he himself now spelled according to the Lithuanian transliteration) identified themselves with the Lithuanian state and the nation. In a letter to state authorities written on 25 January 1940, Šinkevičius claimed to be happy that the Vilnius region had been reunited with mother Lithuania:

\footnotetext{
$31 \quad 391-4-1846-29$.

32 391-4-1846-29ap, 3o, -3oap.

33 For portrayal of the relations between Vytautas and Jogaila in history textbooks, see a semi-official seminal volume, A. Šapoka, Lietuvos istorija (Kaunas: Book Publishing Commission of the Ministry of Education 1936), 102-150.
} 
Lithuania's independence blossomed in all its greatness in the old, Lithuanian capital founded by the grand dukes in the eternal sanctuary Vilnius! We had been waiting for 19 years longing for our true masters to enter the Lithuanian Vilnius region and the old capital-Vilnius. What we had been waiting for for 19 years, has happened! Truth has won! Truth and right are alive! The thrill of joy went through all Lithuanian Tatars! Lithuanians entered their capital not only as its permanent master but also as a true mother of this Lithuanian land! While regaining the capital, we receive her like an eastern dawn of the new times for the new achievements of the Lithuanian nation.

We pray for the freedom and well-being of Lithuania! We have grown together organically with the history of the Lithuanian nation, we are Tatars of Lithuania. We add our voice to the voice of our beloved brother Lithuanians! It is worth working and living! It is worth building such life that the Lithuanians and the Lithuanian Tatars become even closer brothers, that happiness ruled in our motherland Lithuania! How terrible it was when brother was separated from brother. ...In this land, where the true masters are the Lithuanians, some violent people, some invaders were "lords," however...they perished! They wanted to separate the Lithuanian Tatars of the Vilnius region from the Lithuanian Tatars and Lithuanians living in free Lithuania and sought to Polonize them. However, the Tatar masses sincerely rejected such "works" and in the passport of every Tatar it was written: Lithuanian Tatar. ${ }^{35}$

Though it is highly plausible to suspect that the mufti expressed his (and the Tatars' of the Vilnius region) loyalty to the Lithuanian state and nation only instrumentally (further in the letter he pleads with the minister to found a "Muslim Muftiate" in Vilnius and provide for the salaries of the "clergy"36), his words are nonetheless symptomatic of the situation of the wider Tatar community, which by virtue of being a negligible and weak minority needed to repeatedly reconfirm its identification with the state and the nation in the territory in which it found itself. The Tatars of the Vilnius region once again had to reconstruct their identity and this time it must have been even more difficult, for as I show further below, the Tatars of the Lithuanian provinces were far from welcoming toward their co-religionists. 
Though relatively dispersed, organizationally Muslims in interwar Lithuania (before the Vilnius region became part of it) had three independent and physically rather distant congregations (which they called 'parishes'), centering on the surviving mosques-the most numerous the Raižiai Mohammedan ${ }^{37}$ Parish in Alytus District, Kaunas Mohammedan Parish (in 1936 registered as Kaunas Muslim Society), and the smallest of them Vinkšnupiai Mohammedan Parish (though the 1923 census hardly registers a Muslim presence in that part of the country). Out of inertia and tradition, congregations continued to elect their own spiritual leaders (internally called mullas). So, for instance, Kaunas Mohammedan Parish unanimously elected a new 'parish priest (mulla)' in 1922 after the previous one had died, ${ }^{38}$ and he officially introduced himself as the 'rector of the parish.' 39

Despite the fact that there had never been any significant Muslim presence in Kaunas, after it became the capital of Lithuania, local Muslims registered a religious community there in the fall of 1923 and by the second half of 1925 came up with a plan to establish a Faith Organization of Lithuanian Mohammedans which would supervise and coordinate the religious activities of all the Muslim congregations in the Republic of Lithuania. It is worth noting that the Muftiate in Polish-controlled Vilnius was established in December of the same year. This coincidence is hardly accidental-Kaunas Muslims must have known of the plans of their co-religionists in Vilnius and might have emulated them. The temporary rules for the supervision of the relations between the envisioned Faith Organization and the Lithuanian government foresaw the seat of its governing body, the Mohammedan Central Council, as being in Kaunas. This council would consist of three members elected by congregation representatives, two per each 150 congregation members. ${ }^{40}$ However, at that time the idea of a central spiritual governing body in Lithuania did not materialize, mainly due to a lack of commitment and the widespread mistrust among the Muslims of the provinces, who made up the majority of Lithuania's Muslims, of the Kaunas congregation's intentions.

37 In the interwar period Lithuanian Muslims frequently referred to themselves as
"magometonai"- "Mohammedans."
38 391-4-1825-134.
39 391-4-1825-117.
$40 \quad 391-4-1821-75$. 

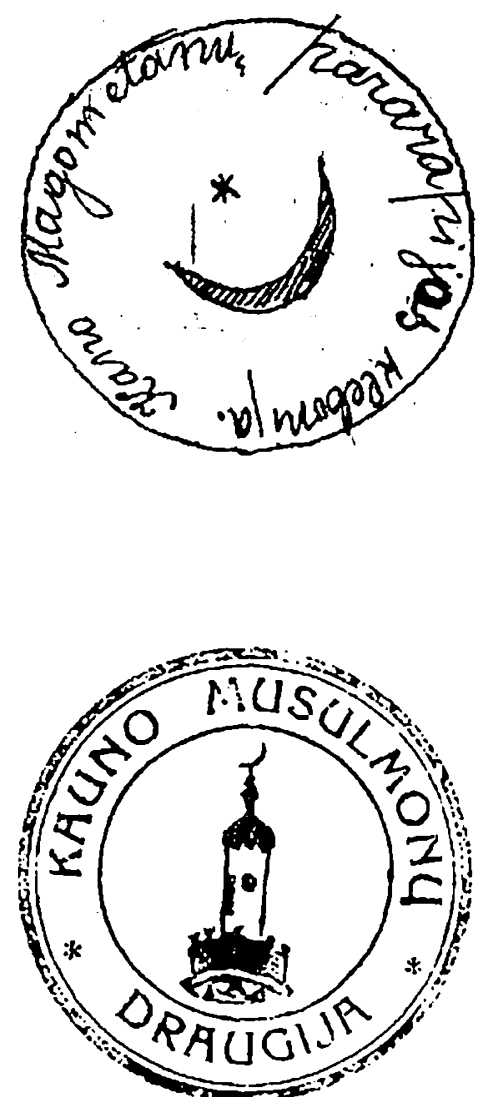

FIGURE 8.1

Sample of the requested stamp of the

Rectorate of Kaunas Mohammedan Parish, ${ }_{3}$ October $1923^{41}$
FIGURE 8.2

Kaunas Muslim Society's stamp, on a document dated 9 September $1937^{42}$

After the local organization's reorganization in 1930 into a purely religious (rather than a confessional Tatar) organization named the Kaunas Muslim Society (officially registered in 1936 and headquartered in the interim capital close to the seat of power), the most active members of the Kaunas congregation apparently had hoped that the relevant state authorities would recognize their new/old organization as the de facto leader among the nation's Muslim congregations and as the center around which provincial congregations should unite. The state appears to have, for a moment, subscribed to this idea and entrusted Kaunas Muslim Society with the supervision of a state allowance and its distribution among the three acting imams. Members of the Society, perceiving themselves as acting on behalf of and in the name of the state, in

\footnotetext{
41 391-4-1821-117.

$42 \quad 391-4-1845^{-48}$.
} 
June 1937 paid an unannounced visit to Vinkšnupiai to inspect the mosque and the cemetery which they later claimed, in their report to the Ministry of Education, to have found in an appalling state-the mosque being in a bad shape and therefore permanently closed, and the cemetery neglected. ${ }^{43}$ Because of this, the Society proposed that the ministry temporarily withhold the allowance from the mulla of the Vinkšnupiai congregation.

Possibly emboldened by the state's sympathetic attitude toward it (especially during the construction of a new brick mosque in Kaunas in 1930-1932, see below), in 1937 Kaunas Muslim Society made a second attempt to unify the Muslim congregations under its leadership; it submitted a request to relevant state authorities for the establishment of a unified Muslim confessional center. In the request, the Society's leadership argued that in the absence of administrative oversight, individual mullas sometimes failed in their duties, could not come to terms to coordinate their activities, and also disregarded advice by congregation members, however, they themselves supposedly realized a need for such a unifying body. ${ }^{44}$ Thus the authors "humbly ask" that the addressed official in charge of religious affairs "takes the initiative into his hands to unite the actions of the mullas by appointing for this purpose one of them as Imam (dean) and entrusting the rest to his leadership." ${ }^{45}$

Internal communication in the Ministry of Education suggests an initial positive reaction and the ministry encouraged Kaunas Muslim Society to prepare a document to serve as the basis for the centralization of the Muslim organizational structure in the country; the Society soon did this. ${ }^{46}$ In its letter accompanying the draft of "The Rules of the Centralization of Muslim Confessional Institutions," Kaunas Muslim Society leadership urged the relevant state authorities (identified as ministries of education and interior) to act promptly as the "founding of a highest Muslim clergy body (Muftiate) is an urgent and necessary matter." 47

The Society's draft of "The Rules of the Centralization of Muslim Confessional Institutions" stated at the outset that the supervision of Lithuanian Muslim confessional institutions "belongs" (direct translation from the original Lithuanian) to the mufti of the Lithuanian Muslims and the muftiate's headquarters should be in the capital of Lithuania, though the document does not

\footnotetext{
43 391-4-1845-37.

44 391-4-1846-40.

45 391-4-1846-40.

$46391-4-1846-36,-36$ ap.

$47 \quad 391-4-1846-36$.
} 
indicate whether the capital is Kaunas (officially perceived to be only a temporary capital) or Vilnius (officially seen as "occupied," yet the only true capital). However, at the end, the rules clarify the situation- "the capital of Lithuania" is meant to be Vilnius. And as long as Vilnius remained in Polish hands, the duties of the mufti were to be conferred temporarily to someone residing in "the interim capital" (i.e., Kaunas).

According to the proposed rules, only citizens of Lithuania, older than 35 years and with higher education were considered eligible for the post which one would occupy after winning elections arranged during the convention of delegates of Muslim congregations. The tenure would be for life. According to the proposed rules, the functions of mufti would comprise spiritual guidance ("interpreting questions of the Islamic faith," "accepting individuals of other faiths into the Muslim faith and setting general rules"), and administrative tasks (controlling the activities of Muslim "clergy" (direct translation from the original Lithuanian), checking registration books maintained by local imams and submitting relevant information to the supervising ministry, "controlling faith instruction," supervising the property of Muslim confessional organizations, arranging the salaries of "clergy" and employees at confessional institutions). Imams (or "clergy," as they are interchangeably called) were to be elected by congregations but would submit to mufti's authority; he would be entrusted with the right to dismiss them.

Unfortunately for Lithuania's Muslims, this second attempt failed also. The provincial congregations (centered around the Raižiai and Vinkšnupiai mosques) rejected the initiative outright and even openly suggested that the despised Vilnius-based Polish Muslim organizations, who were even accused of having sent the very draft of the rules, must be behind this latest attempt by the Kaunas congregation..$^{48}$ For the sake of fairness, one has to admit that the submitted draft of "The Rules of the Centralization of Muslim Confessional Institutions" was conspicuously reminiscent of the statute of the Muslim Religious Union of Poland adopted in Poland in the summer of $1936 .{ }^{49}$ In reaction to the insinuations by the provincial congregations and in view of communal squabbles (described in detail below), the Department of Culture at the Ministry of Education in December 1937 informed the official representative of the Vinkšnupiai congregation in Kaunas that "the question of the centralization of the Muslim faith is for the time being put off." 50

\footnotetext{
48 391-4-1845-10.

49 Bairašauskaitė, "Musulmonų konfesinè bendruomenė," 107.

$5^{\circ} \quad 391-4-1845^{-27}$.
} 
The feeling of independence (but also the short-sightedness caused by provinciality) among the members of the two provincial congregations must have been so entrenched that though minuscule in numbers and surrounded by a majority of people of a different faith, the Lithuanian Muslim community throughout the period of the independent interwar Lithuanian Republic was cursed with permanent self-inflicted disunity. This disunity, in the form of open animosity, appears to have escalated and reached its peak during the Kaunas Muslim Society's renewed attempts to both legally and practically take the reins of Muslim affairs into their hands, starting in 1937. This was the time when the provincial congregations started barraging the relevant state authorities with complaints full of insinuations and conspiracy theories.

The Vinkšnupiai congregation was especially hostile toward the Kaunas Muslim Society. In their August 1937 reply to the report submitted by the Society to the Ministry of Education on the state of affairs in the Vinkšnupiai congregation, the congregation leadership sent a five-page letter in which it accused the Kaunas Muslim Society of exceeding its powers and meddling in the internal affairs of the Vinkšnupiai congregation. ${ }^{51}$ The authors accused (and indeed rightfully) the Kaunas Muslim Society of seeking to subjugate and even include the Vinkšnupiai congregation in the Kaunas congregation. ${ }^{52}$ They further charged the Society with sowing discord both inside the Kaunas congregation itself and among the Muslims of Lithuania and argued that the Society should not be seen by the state as the representative of Lithuania's Muslims. ${ }^{53}$ Finally, the Vinkšnupiai congregation requested (though it reads more like a demand) that the ministry cease transferring allowance money to the Society and rather resume the earlier practice of disbursing it directly to imams. ${ }^{54}$

Almost the same accusations that were leveled at the Kaunas Muslim Society were reiterated in a shorter letter later (written in September 1937), this time signed by representatives of both provincial congregations. ${ }^{55}$ This suggests that the two congregations joined their efforts in their fight against the perceived hegemony of the Kaunas Muslim Society. In this particular letter the authors argued that the two provincial congregations were centuries old and had always

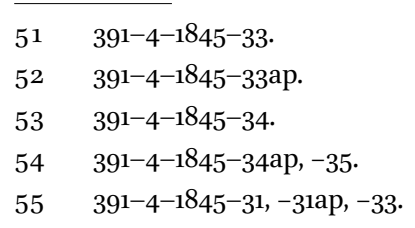


been independent in their spiritual affairs with imams elected locally, something that the Kaunas congregation, being a new formation, lacked. ${ }^{56}$ In the letter, as in the previous letters, the Society was called a small private organization with its membership consisting of relatives and therefore the claim was made that it was not representative of the wider Muslim population in the country.

Finally, at the end of the same year, Aleksandras Chaleckas, the representative of the Vinkšnupiai congregation in Kaunas, wrote yet another similar five-page letter to the Minister of Education, reiterating most of the earlier accusations leveled at the Kaunas Muslim Society and at the same time addressing, from the perspective of the Vinkšnupiai congregation, the issues raised in the report of the Society's fact-finding mission. ${ }^{57}$

Further intra-congregation hostility is displayed openly in numerous subsequent letters from provincial congregations to the state authorities. In one of them, an anonymous letter dated as late as 28 October 1938, the Kaunas congregation was bluntly called "a real and unbearable misunderstanding among Mohammedans." 58

The animosity between the congregations based in the capital and the provincial congregations crossed the limits of a simple internal power struggle and was intentionally extended by the provincial congregations to include the question of the congregation's position on and relations with the citizens of the arch enemy-Poland. The provincial congregations went so far as to accuse the Kaunas based Muslim activists of treason because of their alleged cooperation with the Vilnius-based Muslims. For instance, in their aforementioned lengthy letter to the Minister of Education written on 28 October 1938, and marked "Secret," its authors claimed that the Kaunas Muslim Society was maintaining close relations with Muslim organizations ("Związek kulturalno oswiatowy" and "Muftiat"), based in occupied Vilnius. At the purported instigation of these Polish organizations, with which they supposedly "had secret relations," and from which they "used to receive instructions," activists of the Kaunas Muslim Society "would engage in various intrigues and misunderstandings among Mohammedans, fighting this way with the Lithuanian spirit of Mohammedans and with this very much obstructed the execution of useful work." ${ }^{59}$ The Kaunas Muslim Society was deemed to have received advice from the Polish side to "try and take under its tutelage Mohammadan parishes and

\footnotetext{
$5^{6} \quad 391-4-1845^{-} 31$.

57 391-4-1845-28, -28ap, -29, -29ap, -30 .

58 391-4-1845-9.

$59 \quad 391-4-1845^{-10}$.
} 
create a central Mohammadan organization made purely of Polephiles (Lith. lenkomanai)." 60

The provincial (in this case, Vinkšnupiai) congregations must have been convinced that Muslims based in Vilnius harbored ill will for those living in Lithuania. They alleged that as a Polish organization the Vilnius Muftiate was more a political organization and a tool in the hands of the Polish state than a faith-based institution: the Muftiate and its affiliated organizations are charged with having "secret political goals and work" which they (the Polish Muslim organizations) and "their agents cover and dress in supposedly Mohammadan faith matters," ${ }^{\prime 1}$ while in reality "the special purpose" of these organizations was "to Polonize Mohammedans in Vilnius and elsewhere and to look for a means to bind the Lithuanian Mohammedans to Polish organizations." 62

Though it cannot be read directly from the available archival material, one might conclude, hypothetically, that because of their low level of religious and other education and lack of erudition and because of their somewhat heightened concern to preserve their independence and purity from foreign influences, let alone control, the Muslims of interwar Lithuania, unlike those of Poland, did not seek closer cooperation or integration with the Muslim communities elsewhere in Europe or in Muslim-majority states. There is very little evidence to suggest that Lithuanian Muslims tried to approach their co-religionists abroad. One such rare occasion can be found in a letter in the fall of 1933 written by Chaleckas, the imam of the Kaunas mosque, to the Moslemische Revue, a German language Ahmadi periodical, informing the editors of the opening of a new mosque in Kaunas. In its October 1933 issue Moslemische Revue published a short note on the opening of the Kaunas mosque, indicating that the information was drawn from the received letter. ${ }^{63}$ It remains unclear if such a letter had been sent to other Muslim organizations or publications elsewhere and whether the Lithuanian Muslims were aware of Moslemische Revue's Ahmadi nature.

The lack of evidence of transnational communication, let alone cooperation, between Lithuania's Muslims and those elsewhere in (western) Europe during the interwar years suggests that the Lithuanian Tatars were preoccupied with other issues they deemed more urgent and relevant. The identity

\footnotetext{
6 o $391-4-1845^{-10 .}$

$61391-4-1845-9,10$.

62 391-4-1845-9.

63 “Eine Neue Moschee zu Kaunas in Litauen," Moslemische Revue (Oct. 1933), 91-92.
} 
shifts the Tatars of the former GDL went through after the break-up of the Russian Empire initially took most of their efforts. Afterwards, attempts and the constant failures at institutionalization caused by the demographic distribution of Tatars and intra-communal relations prevented the avant-garde of Lithuania's Muslims based in Kaunas from forging long-term relations with Muslims in Europe, let alone in the wider world. From this perspective, one can only lament that though the Lithuanian Tatar community had been, by the beginning of the twentieth century, one of the oldest Muslim communities that had lived in Europe continuously, it failed to tap into the newly forming vibrant and complex transnational networks of Muslims in interwar Europe, something that undoubtedly would have significantly enriched the local community.

\section{Developments after the Regaining of the Vilnius Region}

The Soviet occupation of the eastern part of the Polish Republic in the first month of World War II (which began on 1 September 1939) led, on 10 October 1939, to the Vilnius region (with its significant Muslim community, estimated at some $670,{ }^{64}$ and home of the Muftiate) being given by the Soviets to Lithuania. After regaining the Vilnius region, the number of Muslim congregations in Lithuania doubled to six. The Kaunas Muslim Society then made a final attempt to unify these congregations under one umbrella organization. In their "Memorandum" of 29 November 1939 to the Minister of Education they called on the minister to either promulgate the 1937 "Rules of the Centralization of Muslim Confessional Institutions" or solve the problem in some other way. ${ }^{65}$ This last attempt appears to have been welcomed by the Raižiai congregation, which had apparently switched sides and which in its letter of 29 December 1939 not only urged the Minister of Education to move quickly in solving the lasting impasse but was also full of praise for the mufti who, it claimed, was "full of love to Mohammedan-Muslim faith and Lithuania, his motherland." 66

However, the Vinkšnupiai congregation remained unwavering and renewed its bombardment of state institutions with letters of complaint about the perceived intentions and activities of the Vilnius-based Muslim leadership, chiefly manifest in the person of Jokūbas Šinkevičius/Jakub Szynkiewicz. In his letter

\footnotetext{
64 Bairašauskaitė, "Musulmonų konfesinė bendruomenè," 110.

65 391-4-1846-41.

66 391-4-1846-30.
} 
of 17 November 1939, the representative of the Vinkšnupiai congregation in Kaunas pleaded with the Ministry of Education not to allow the reopening of the Muftiate. ${ }^{67}$ In their later letter, coincidentally (?) dated the same day (29 December 1939) as the supportive Raižiai letter, several members of the Vinkšnupiai congregation argued that "for many years we did joint Lithuanian work not so that now, after regaining the Vilnius region, we would import Polish leaders for ourselves and even foreigners (Jakub Šinkevič)... and all sorts of troublemakers" and suggest that these "mind their own business." ${ }^{\text {" }}$ Just a day later (30 December 1939), in another and more detailed letter, several representatives (some of them the same as in the letter a day earlier) of the same Vinkšnupiai Mohammadan Parish argued that "Lithuanian Mohammedans do not want any Polish leaders to be their go-between (Janušauskai, Vilčinskai from "Kaunas Muslim Society") and we protest against the work of them all." The authors were adamant: "We did not do patriotic Lithuanian work for 20 years to put on ourselves the noose of Polish leaders now, after having regained Vilnius (???)." In the end, they even issued a judgment on Šinkevičius' / Szynkiewicz's prospects of receiving Lithuanian citizenship: "The above mentioned Jakub Šinkevič [Jakub Szynkiewicz] cannot be a citizen of Lithuania, because he was born in the town of Liachovičiai [Lachowicze], close to Baranovičiai [Baranowicze], and his friends want to import him to us." ${ }^{\prime 9}$ Finally, the authors pleaded with the minister to "definitively close the aforementioned Polish organizations ("Muftiat"), not to give any money to Polish leaders and to prevent their interference in our affairs." ${ }^{70}$

Despite these protests by the Vinkšnupiai congregation, in January 1940, local authorities in Vilnius allowed the Muftiate to operate unofficially until it "obtains the permit to operate legally."71 At the end of January Šinkevičius approached the Minister of Education with a letter requesting that the Muftiate be reopened and that funding for the salaries of its employees be allocated. ${ }^{72}$ The imminent annexation of Lithuania in the summer of 1940 by the USSR and subsequent occupation by Germany made all this impossible. However, Šinkevičius/Szynkiewicz remained in Vilnius throughout the Nazi occupation until 1944, when, in his capacity as the spiritual head of the Muslims in the area

\footnotetext{
$67 \quad 391-4-1846-42$.

68 391-4-1846-50.

69 391-4-1846-48ap.

$70 \quad 391-4-1846-49$.

$71401-2-160-17,18$.

72 391-4-1846-22, 22ap.
} 
and in the wake of the Soviet return of Lithuania, he emigrated first to Egypt and later (in 1957) to the United States where he died in $1966 .{ }^{73}$

\section{The State's Position}

The constitutions (all of them, in 1922, 1928, and 1938) of interwar Lithuania affirmed general religious freedom. However, no further legal regulations between the Lithuanian state and its Muslims were promulgated and practical relations between them appear to have been based more on moral commitment and goodwill from the state's side than on formal obligation. It was primarily the Department of Faiths at the Ministry of Interior, and later, in the 1930s, the Department of Cultural Affairs at the Ministry of Education that were charged with the supervision of religious affairs and represented the state in dealings with the Muslim congregations. Ultimately, most of the documents preserved at the Lithuanian State Archive are either letters by Muslims addressed to one of these departments or their replies to the queries from Muslims.

The communication (and the cooperation stemming from it) between the relevant state institutions and the Muslims in the interwar period, in which the state's position vis-à-vis the country's Muslims can be discerned, can be divided into three areas: (a) continuous financial support for congregations in the form of allowances for imams; (b) financial support for building a new mosque in Kaunas; and (c) expected state arbitration in the relations among the Muslim congregations.

With regard to the allowances, in June 1929, Kaunas Mohammedan Parish approached the prime minister with a request to "assign permanent salary" for the congregation's imam (in the document called “dvasiškis," or "clergyman"). ${ }^{74}$ The petitioners based their request on the fact that though the former clergyman would be content with the 100 litas allowance provided by the Department of Faiths and would serve as the imam "out of dedication, without requiring a separate salary," with his passing away, the congregation, on its own, "without the state's support...in no way can sustain a clergyman." The request was received favorably and dealt with promptly (on the same day as it arrived at the prime minister's chancery) by Prime Minister Augustinas Voldemaras personally, who in his handwritten resolution on the very same letter sympathized

73 Adas Jakubauskas, Galimas Sitdykovas, Stanislavas Duminas (eds.), Lietuvos totoriai istorijoje ir kultūroje (Kaunas: Lietuvos totorių bendruomenių sajunga, 2012), 148. 
with the local Muslims. ${ }^{75}$ Ultimately, the state resolved to pay modest semiannual allowances to the imams of all three parishes. ${ }^{76}$

The Tatars professed loyalty to the state and were generously rewarded by the government - it provided the bulk of the funding for a new (to this day the sole) brick mosque in the interim capital Kaunas; the mosque opened its doors to worshipers in 1932. Though initiated by the Kaunas Tatars in 1930, ${ }^{77}$ they saw the financial burden of bringing the mosque from its inception to completion as the state's responsibility. Local Tatars (in the letter their numbers are given as 200 in the Kaunas region with just 70 in city of Kaunas itself ${ }^{78}$ ) could not have expected to collect the needed amount (originally estimated at a staggering 85 thousand litas), thus they immediately proceeded with lobbying the minister to make the funds available. The Kaunas mayor and other relevant authorities approved of the construction..$^{79}$ In the end of the same year the Tatars once again requested 25 thousand litas from the state for the completion of the mosque, citing their failure to raise additional funds from within the community. 80

Though the surviving archival material does not allow one to speculate as to what extent the Lithuanian government wanted to control and even meddle in the internal affairs of the local Tatar community, the fact of Lithuania's state of war with Poland over Vilnius and its region must have weighed on the Lithuanian government's position both toward its Tatar community and especially this community's relations (ties) with their co-religionists in Poland, especially the Vilnius region. As shown above, the two provincial congregations bombarded the relevant government authorities about the perceived treason of the Kaunas Muslim Society in favor of Poland. However, it appears that the government, in spite of the wishes of the provincial congregations to avoid dealing with the Kaunas Muslim Society, chose a path of pragmatic cooperation with it. One might even argue that the government's reaction in the form of its dealing with and treatment of the Kaunas Muslim Society suggests that the state authorities rather saw in it a partner and even a possible national leader of all of Lithuania's Muslims. And it was only under pressure from the provincial congregations that the government tacitly withdrew its open support for the Society.

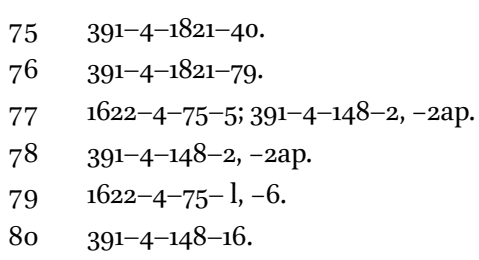


After establishing control over the lands formerly held by Poland, the Lithuanian authorities outlawed all Polish-registered organizations, including the Muftiate and its premises, which were locked and sealed. ${ }^{81}$ However, after intense lobbying by the Kaunas Muslim Society (now supported by the Raižiai congregation) and Mufti Šinkevičius (who, by the way, had been denied Lithuanian citizenship ${ }^{82}$ ) personally, the authorities allowed Šinkevičius to resume his functions for a time, though without pay or office; in this way they showed some sympathy for the Tatar cause, both in the sense of fulfilling their spiritual needs and communal unity.

\section{Conclusion}

The interwar period was in practice the time in which the local Tatar Muslim community, which consciously identified itself with the Lithuanian nationstate (in contrast to its earlier identification with the Grand Duchy of Lithuania, which had covered parts of Poland, Belarus, and Ukraine), was born. This identity was closely tied to the myth of origin and settlement stories in which the bravery and loyalty of the Tatars in the army of Vytautas the Great and his gratitude to the Tatars were central. At the same time, the community appears to have shown little interest in the outside world or Muslims living elsewhere, either in Europe or further afield. The more numerous provincial congregations took an insular stance and did not pursue transnational communication, let alone cooperation, with Muslim communities and organizations abroad; this facilitated the community's overall provincialism, lack of familiarity with, and remoteness from contemporary processes in the religious sphere of the world's Muslims, namely reformism and revivalism.

In spite of this unitary narrative of belonging to and in the land, and unlike their co-religionists in Poland, in the interwar period the Muslims (especially those based in the provinces) of the Republic of Lithuania failed to realize a need for or see the benefit in a greater institutionalization of Islam in its territory and instead continued with the tradition of independent congregations (parishes), a tradition they had inherited from the times of the Grand Duchy of Lithuania, and resisted centralization and institutionalization very much like they had in Russian times. In Bairašauskaite’'s opinion, ${ }^{83}$ the part of the original community of the 'Muslims of the GDL' which found itself within the borders of the Republic of Lithuania was intellectually not advanced.

\footnotetext{
81 Bairašauskaitè, "Musulmonų konfesinė bendruomenè," 111.

82 Ibid., 112.

83 Ibid., 105 .
} 
This certainly appears to be true in the case of the provincial congregations; however, the core that comprised the Kaunas Muslim Society seem to have been 'progressive'- they not only sought to unite Lithuania's Muslims under a single umbrella organization and thereby raise the standards of Islamic practices, but had an even broader vision and were also open to cooperation with the Vilnius-based Muftiate. In this regard, the Muslims of the interim capital, or at least the most active among them, and the provincial Tatars had rather divergent perspectives on the development of the Lithuanian Muslim community. As Bairašauskaite ${ }^{84}$ correctly points out, "contradictory positions of Muslim parishes were caused by inner competition and different political attitudes, which were obstacles for making decisions on creation of confessional center." At the same time, with no pressure (or support) from above (e.g., state authorities), there were no interested players strong enough to organize Lithuania's Muslims into a coherent faith community that would have mirrored the one in interwar Poland.

The stubbornness of the Vinkšnupiai congregation and its bickering with the rest of Lithuanian Muslims lasted to the very end, when in the summer of 1940, the Soviet Union occupied and annexed all of Lithuania, thus terminating the state's and also the Muslim community's independent existence. World War II dealt a final blow to the Vinkšnupiai congregation-its mosque was destroyed by German troops, its members uprooted and dispersed. Today, only the cemetery remains as a reminder of the tiny yet unwavering western-most congregation of Lithuanian Tatars.

The story of the interwar Lithuanian Muslim community presented above remains, however, incomplete. This is a result of the scarcity of archival and other research material. On the other hand, there are still some living witnesses of the time and certainly their progeny, whose testimonies could be usefully employed in a more comprehensive (and much needed and timely) research on this most neglected period in the history of the Lithuanian Tatar Muslim community. Such research could potentially build and expand on the work in this article. One can only wish this comes true, and sooner rather than later.

\section{Bibliography}

\section{Archival Material}

Lithuanian Central State Archive, inventory numbers (collection-folder-case-sheet): 391-4-148-2, -2ap, -16.

$84 \quad$ Ibid., 111. 


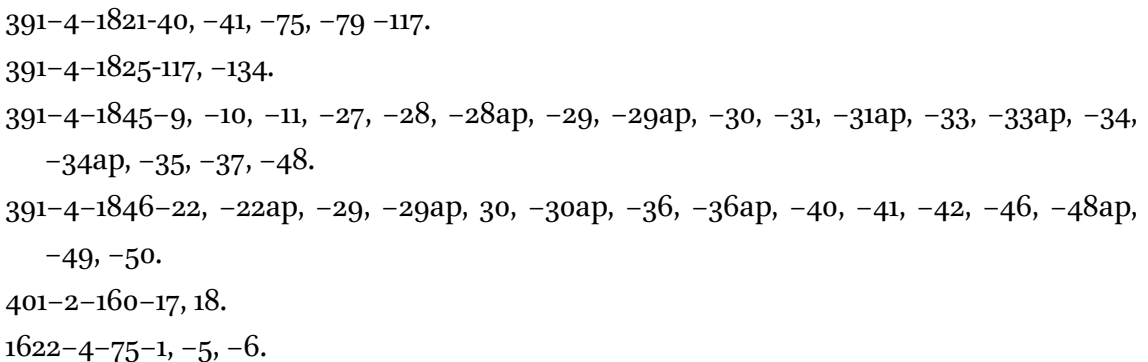

\section{Literature}

Высочайше утвержденное мнение Государственного Совета 8 января 1851 г. об избрании мулл в магометанских обществах Западньх Губерний [The opinion of the State Council of 8 January $185^{1}$ on the election of the mullahs in Mohammedan communities of the western provinces approved by His Majesty]. http://constitutions. ru/archives/3239, accessed 10 April 2011.

Bairašauskaitè, Tamara. "Musulmonų konfesinė bendruomenė nepriklausomoje Lietuvoje." Lietuvos istorijos metraštis 1991 (1993): 98-114.

- Lietuvos totoriaiXIX amžiuje. Vilnius: Mintis, 1996.

Central Bureau of Statistics. Lietuvos gyventojai: 1923 m. rugsèjo 17 d. surašymo duomenys. Kaunas: Centrinis statistikos biuras, 1925 .

Jakubauskas, Adas, Galimas Sitdykovas, Stanislavas Duminas (eds.). Lietuvos totoriai istorijoje ir kultūroje. Kaunas: Lietuvos totorių bendruomenių sajunga, 2012.

Kolodziejczyk Dariusz. The Crimean Khanate and Poland-Lithuania: International Diplomacy on the European Periphery (15th-18th Century): A Study of Peace Treaties Followed by an Annotated Edition of Relevant Documents. Leiden: Brill, 2011.

Kričinskis, Stanislovas. Lietuvos totoriai [Lithuanian Tatars]. Vilnius: Mokslo ir enciklopedijų leidykla, 1993 .

—. Tatarzy litewscy. Próba monografii historyczno-etnograficznej [Lithuanian Tatars: An attempt at historic-ethnographic monograph]. Warsaw, 1938.

Miskiewicz, Ali. Tatarzy polscy 1918-1939. Zycie spoteczno-kulturalne i religijne. Warsaw: PWN, 1990.

Moslemische Revue. “Eine Neue Moschee zu Kaunas in Litauen.” (Oct. 1933): 91-92.

Šapoka, A. Lietuvos istorija. Kaunas: Book Publishing Commission of the Ministry of Education, 1936.

Senn, Alfred Erich. Lithuania Awakening. Los Angeles: University of California Press, 1990. 


\title{
Transnational Life in Multicultural Space: Azerbaijani and Tatar Discourses in Interwar Europe ${ }^{1}$
}

\author{
Zaur Gasimov and Wiebke Bachmann
}

Dans la période entre les deux guerres, la presse européenne dite d'information ne traitait que rarement des problèmes de l'Orient musulman. ${ }^{2}$

After a short intermezzo between 1918 and 1921, Soviet Russia was able to reconquer most of the territories of the former Tsardom in the Caucasus, the Ukraine, and in Central Asia, which became independent or at least self-ruled around 1917. The short-lived independent republics of Crimea, Azerbaijan, and Turkestan ${ }^{3}$ with their predominantly Muslim population were occupied by the Red Army, and then gradually sovietized. ${ }^{4}$ The Sovietization challenged the political elites of these countries dramatically. Those who survived the invasion of the Bolsheviks either had to accept the Communist regime or escape. Thousands of former politicians and intellectuals, both Shīa and Sunnīs, left for Turkey, France, Germany, and Poland. While living in exile many continued political, journalistic, and public activities writing against Communism, and protesting against the persecutions in the Soviet Union. At the same time, these intellectuals were eager to inform the society in their host countries about their countries of origin, which were left under Soviet occupation. Being quite well integrated into the intellectual milieus of interwar Paris, Warsaw, Berlin, and other European cities in the 1920s and 1930s, they were confronted with European realities, ideas, and views on Christianity and Islam.

1 All translations from Polish, Turkish, Azerbaijani, and German were done by the authors of the contribution.

2 Haidar Bammate, Visages de l'Islam (Lausanne: Payot, 1946), 1.

3 Here Turkestan refers to the geographic name of the region of Central Asia that was dominated by Russia until 1991.

4 For more on the period of the short-lived independence, see Firuz Kazemzade, The Struggle for Transcaucasia: 1917-1921 (Westport, Ст: Hyperion Press, 1981).

(C) ZAUR GASIMOV AND WIEBKE BACHMANN, 2016 | DOI 10.1163/9789004301979_010 
This article explores selected publications, articles, and booklets of several prominent Azerbaijani, ${ }^{5}$ northern Caucasian, and Tatar émigré intellectuals in interwar Europe, including Mehmed Emin Rasulzade (1884-1955), Hilal Munschi (1899-?), Ahmet Zeki Velidi Toğan (1890-1970), Haïdar Bammate (1890-1965), and Cafer Seydahmet (1889-1960); these works were published in Europe in Russian, Polish, French, and German. The analysis here focuses on the representation of Islam in the writings of these Muslim intellectuals. Born in the 1880s, all were graduates of Russian and European schools, belonged to the Muslim minority in the Russian Empire, and then spent decades exiled in Europe. Their sojourns in France, Poland, and Germany throughout the 1920s and 1930s did not mean, therefore, a cultural watershed to their primary socialization. As Muslims they were aware of European culture while they lived in the Caucasus or the Crimea under Russian rule. ${ }^{6}$

Socialized under the circumstances of the imperial homogenization 'from above' and certain cultural resistance strategies of non-Russian peripheries and educated in imperial high schools and universities, these intellectuals combined the awareness of Russian, Near Eastern, and European traditions and cultures. It is easier to define them as entangled intellectuals who were rooted in several civilizations, than to try to classify them merely as Azerbaijani, Tatar or Muslim intellectuals in interwar Europe. They represented a multicultural hybridity: ${ }^{7}$ They lived and were active in the special intellectual space of interwar Europe. ${ }^{8}$

5 For more detail on Azerbaijani émigrés in Europe in general and in Germany in particular, see Zaur Gasimov and Wiebke Bachmann, “Für nationale Ehre, Freiheit und Selbständigkeit!' Die publizistische Aktivität der aserbaidschanischen Exilanten in Berlin in der Zwischenkriegszeit," in Brücken bauen-Analysen und Betrachtungen zwischen Ost und West. Festschrift für Leonid Luks zum 65. Geburtstag, ed. Jürgen Zarusky, et al. (Stuttgart: Ibidem Verlag, 2012), 277-294.

6 We argue that at least the urban spaces of the Russian Empire, like Moscow, St. Petersburg, Kazan, Kiev, Odessa, Baku, Bakhchesaray, and Tbilisi can be considered European. Therefore, intellectuals who resettled from St. Petersburg to Paris or from Baku to Warsaw still moved within a European cultural space.

7 In this context the term of hybridity is borrowed from the post-colonialist debates initiated by Homi Bhabha.

8 It is difficult, however, to define this intellectual space as the "third space," in Homi Bhabha's terms. Being in Europe and therefore outside the territory of the Russian Empire and the UssR, Bhabha's third space is hardly applicable with regard to the study of Russian Muslims who migrated to Europe. See Jonathan Rutherford's interview with Homi Bhabha: "The Third Space. Interview with Homi Bhabha," in Identity: Community, Culture, Difference, ed. Jonathan Rutherford (London: Lawrence and Wishart, 1990), 207-221. 
In this context, we investigate the role of Islam as an important element of the self-identification and national identity of these intellectuals. How did the Muslim intellectuals from the former Russian Tsardom react to the European visions and ideas of Islam? How did they eventually try to influence, or 'revise' these conceptions? And how important was Islam to their life in exile and in which regard?

Moreover the correlation of the representation of Islam and, for example, anti-communism, which was the main political focus of these intellectuals in interwar Europe, is taken into consideration. The classification of these Muslim intellectuals in interwar Europe as entangled intellectuals ${ }^{9}$ offers a theoretical approach to historical entanglements and therefore an additional key to understanding the specific representation of Islam under the circumstances of exile.

\section{Entangled Intellectuals}

The entangled intellectuals Mehmed Emin Rasulzade, Hilal Munschi, Zeki Velidi Toğan, Haïdar Bammate, and Cafer Seydahmet were born in different parts of the Russian Tsardom but nevertheless were confronted with the same or at least similar experiences in the peripheries of the empire. As a result of the primary educational socialization in Russian schools they were fluent in Russian and had a good knowledge of Russian culture and literature. The period of their childhood and socialization at the secondary, and high schools that they attended coincided with the severe russification strategy under Tsar Alexander III and Nicolas I at the end of the nineteenth century. ${ }^{10}$ In the same space of time the conservative pan-Slavist ideology was quite widespread in Moscow and St. Petersburg. The Russian pan-Slavist discourse had distinct anti-Turkish and anti-Muslim elements. ${ }^{11}$ Pan-Slavist ideologists, for example,

For the notion of the "entangled intellectual," see Zaur Gasimov, "Bolshevik PostColonialism, Eurasian Perspective and Entangled Intellectuals. Russian Debates on Spengler in the Interwar Period," in Oswald Spengler als europäisches Phänomen. Der Transfer der Kultur- und Geschichtsmorphologie im Europa der Zwischenkriegszeit 19191939, ed. Zaur Gasimov and Carl A. Lemke Duque (Göttingen: V\&R, 2013), 79.

10 For more on russification, see Theodore R. Weeks "Russification/Sovietization," in European History Online (EGO) (Mainz: Institute of European History (IEG), 2010). Accessed 2 Dec. 2013: http://ieg-ego.eu/en/threads/models-and-stereotypes/russification -sovietization.

11 For more on pan-Slavism, its agents, and variety, see the compendium: Post-Panslavismus. Slavizität, Slavische Idee und Antislavismus im 20. und 21. Jahrhundert, ed. Agnieszka Gąsior, Lars Karl, and Stefan Troebst (Göttingen: Wallstein Verlag, 2014). 
promoted the idea of a Russian conquest of Constantinople and Russian domination in the Balkans. ${ }^{12}$ This set of ideas deepened the existing antagonism between the Russian majority and the Muslim minority in the central cities of the empire as well as between the Russian authorities and the Muslim and non-Russian majority throughout the empire.

Rasulzade, Seydahmet, Munschi, Zeki Velidi Toğan, and Bammate, like many other Muslim intellectuals from the Russian Caucasus and Turkestan were, because of its proximity, fluent in Ottoman Turkish and regularly observed the political and cultural processes in Istanbul at the beginning of the twentieth century. They became involved in revolutionary and political activities in the regions they lived in. Most Azerbaijani intellectuals were also fluent in Persian and engaged in political processes in Iran as well. Linguistic competences played a certain role in making possible the transnational activities of these intellectuals by simplifying, to some extent, the crossing of borders. Additionally, at the turn of the century and particularly after the first Russian revolution of 1905, the languages of the Russian Muslim intellectuals became spaces of transboundary communication with the inhabitants of neighboring countries and empires as well as of the articulation of (shifting) personal identities. The Azerbaijani-Turkish entangled intellectual Ahmet Ağaoğlu, who studied in the 1890 at the Sorbonne, presented himself first as a Persian intellectual. He did this in Paris among French orientalists such as Ernest Renan and James Darmestaetter, who considered Persian culture to be a high culture of the Near and Middle East. But after returning to the Russiandominated Azerbaijani capital Baku at the turn of the century, Ağaoğlu became an ardent pan-Turkist and Azerbaijani nationalist. After his emigration to the Ottoman Empire in 1909 he then shared the ideology of the Young Turks and finally joined the Kemalists after the victory of Mustafa Kemal in Anatolia by promoting the idea of Turkish etatism. ${ }^{13}$

The Russian revolution of 1905 , which was followed by a broad liberalization throughout the empire, made those activities possible. But in 1918-20 their political careers at the peripheries of the former Russian Empire reached their end. The Bolshevik occupation obliged them to leave for Europe, which became a new space for their political activities for the rest of their lives.

12 For more on the reciprocal influence of pan-Slavism and pan-Turkism, see Zaur Gasimov, "Vom Panslavismus über den Panturkismus zum Eurasismus. Die russisch-türkische Ideenzirkulation und Verflechtung der Ordnungsvorstellungen im 20. Jahrhundert," in Post-Panslavismus, ed. Gąsior, Karl, and Troebst, 450-474.

13 See Ufuk Özcan, Ahmet Ağaoğlu ve Rol Değişikliği: Yüzyıl Dönümünde Batılı Bir Aydın (Istanbul: Kitabevi Yayınları, 2010). 
There were numerous dimensions of the discursive levels within this group. Rasulzade, for example, traveled in the 1920 and 1930 s between Turkey, Poland, and France, and wrote for Turkish, Polish, Russian, and French newspapers and journals in Paris and Berlin. Writing in Russian for an émigré journal in Paris he, along with Bammate, took part in a russophone debate in the emigrant community from the former Tsardom. Actually, their intellectual sojourn took place in a multi-dimensional and multicultural milieu of exiles. ${ }^{14}$

\section{Cafer Seydahmet's Public Activities in Interwar Poland}

Cafer Seydahmet was born in 1889 in the Crimea to a religious middle-class Tatar family. After attending a primary school in the Crimea and later a lyceum in Istanbul, Seydahmet was enrolled in the law department of Istanbul University (1909-11). ${ }^{15}$ Afterwards he continued his studies in Paris (1911-13) and St. Petersburg (1913-14). ${ }^{16}$ During the Russian revolution and shortly afterwards Seydahmet engaged himself in local Crimean politics (1917-18), ${ }^{17}$ but after the peninsula was occupied by the Denikin Army and then by the Red Army he left for Istanbul in 1918 and then, in the early 1920s he moved to Le Retour, close to Geneva. He stayed in Poland throughout the 1930s. In the countries of his sojourn he wrote extensively for local newspapers and took part in debates of Russian and non-Russian emigrants from the former Tsardom.

In 1930, the Institute of Oriental Studies (Instytut Wschodni) at the University of Warsaw published Cafer Seydahmet's monograph on the history and current state of the Crimean peninsula. His cooperation with Polish intelligence and scientific institutions, which were backed to a large extent by the Polish secret services and diplomatic circles, was particularly intensive and long; he returned to the so-called Promethean concept elaborated by the Polish authorities in the 1920s. The main target of the Promethean network was to combat Soviet Communism ideologically, and later it was aimed at the dismemberment of the Soviet Union and the restoration of the independent

14 The third space, on the other hand, is merely a space of special encounter between the (former) empire and its (former) colony.

15 For more about Seydahmet, see Inci Bowman, "Cafer Seydahmet Kirimer (1889-1960)." Accessed 21 June 2013: http://www.iccrimea.org/historical/cskirimer.html.

16 In his memoirs Seydahmet describes this period in great detail. See Cafer Seydahmet, Bazı hatıralar [Some memories], (Istanbul: Emel, 1993).

17 For more detail on the political process in the Crimea, see Hakan Kurıml, National Movements \& National Identity among the Crimean Tatars (1905-1916) (Leiden: Brill, 1996). 
states of the Caucasus, Central Asia, and the Ukraine. ${ }^{18}$ In accordance with the Promethean strategy, Polish intelligence and the Ministry of Foreign Affairs organized a supranational and multi-confessional network of Polish politicians, academicians, diplomats, and Caucasian (mostly Azerbaijani, Georgian, and North Caucasian), Ukrainian, Crimean, Kazan Tatar, and Central Asian émigrés who had escaped from Soviet Russia and settled in Europe. This network consisted of Promethean clubs located in Warsaw, Paris, Istanbul, Helsinki, and Berlin. They published several journals in French, Russian, Turkish, and Polish that criticized Soviet policy and Communism. For centuries Poland had enjoyed a special relationship with Muslims, and particularly the Turkish-speaking world and Turkey. In the fourteenth century, a sizeable Tatar colony settled in the territory of the Polish-Lithuanian Commonwealth: it was allowed to build mosques and possess its own religious infrastructure. The Ottoman Empire did not accept the divisions of Poland at the end of the eighteenth century and captured the sympathies of Polish intellectuals and elites. During the Crimean War, Polish politicians and intelligentsia frequently visited Istanbul and forged a common Polish-Ottoman front against Russia.

It was a Polish publishing house that published Seydahmet's monograph on the Crimea and Crimean Tatars. It should be mentioned that the book, Krym. Przeszłość, teraźniejszość i dą̇enia niepodlegtościowe tatarów krymskich [Crimea. Past, present and independence aspirations of the Crimean Tatars] was a Polish translation of the original French book, La Crimée; passé-présent, revendications des Tatars de Crimée (published in 1921 in Lausanne by Seydahmet), which was aimed at making French readers aware of the historical background and political events in the Crimea. For the Polish edition, Seydahmet expanded the initial version and covered the period of the 1920 s by elucidating the political and cultural activities of the Crimean Tatar communities in Europe and Turkey as well as the persecutions undergone by the Tatars in the Soviet Union. After prefaces by American, ${ }^{19}$ Swiss, ${ }^{20}$ and Polish intellectuals, Seydahmet introduced readers to the basic geography of the peninsula and described its population. "This blessed country has been since ten centuries populated by Tatars, which belong to a strong (Tatar-Mongol) race of

18 For more about the Promethean movement, see Ruch prometejski i walka o przedbudowe Europy Wschodniej (1918-1940) [Promethean movement and the struggle to reshape Eastern Europe (1918-1940)], ed. Marek Kornat (Warsaw: Instytut Historii PAN, 2012).

19 George Herron was an American socialist. He spent several years in Europe and cooperated closely with Muslim intellectuals from Russia and the Soviet Union.

20 Eugene Pittard (1867-1962) was a Swiss professor of anthropology at the University of Geneva. 
Chingiz-Khan."21 Further, he described the etymology of the word Tatar by analyzing the works of European orientalists and travelers. Seydahmet offers a great deal of information on Tatar folklore and customs in this sub-chapter but almost nothing on Islam.

In this context it is quite interesting how Seydahmet described Crimean architecture. "By analysing the Crimean architecture we see that Tatars shaped their own style by combining the Western influence with the Arab, Turkestani, and Istanbul architecture."22 Furthermore, the author referred to the mosques Cuma-Cami in Eupatoria ${ }^{23}$ as well as Khan-Cami in the Crimean capital Bakhchi-Saray. Seydahmet added to his own reflections with quotations from the works of western historians and travelers like François Baron de Tott, Arthur Schnitzler, Louis de Soudak, and Peter Simon Pallas. In the sub-chapter on "Enlightenment and Literacy" Seydahmet mentions the "competence among the Tatars to read the Koran" 24 from the sixteenth century and beyond. The history of the relations between the Crimean Khanate and Poland was a topic that he elucidates in a particular detailed way; ${ }^{25}$ because the book was published in Poland and in Polish, therefore Polish readers were his target group. However, the occupation of the khanate by the Russian Tsardom during the second part of the eighteenth century was the main focus of the monograph, and in its core chapters Seydahmet touches to some extent on the topic of Islam. In the chapter about Russia's "Hostile relations to the clergy" in the Crimea, Seydahmet describes the policy of the Russian authorities on imams in the peninsula. He wrote that mistrust towards the Tatar population was characteristic for Russian authorities and their attitude towards the local imams, particularly those who graduated from theological high schools in Egypt and Turkey, as well as Kazan and Orenburg. Additionally, Seydahmet informs his readers about the Russian authorities' expropriation of land that belonged to mosques and Muslim foundations during the eighteenth century. ${ }^{26}$

In the second part of the nineteenth century St. Petersburg suppressed the resistance of the mountaineers in the northern Caucasus and managed to

21 Dżafer Sejdamet [Cafer Seydahmet], Krym. Przesztość, teraźniejszość $i$ dążenia niepodlegtościowe tatarów krymskich (Warsaw: Instytut Wschodni, 1930) 10.

22 Ibid. 37.

23 Eupatoria or Yevpatoria (Tatar: Kezlev) is a town in the Crimean peninsula with a predominantly Tatar and Karaim (Jewish) population, until the Russian conquest at the end of the eighteenth century.

24 Sejdamet, Krym, 41.

25 Ibid., $48-5^{2}$.

26 Ibid., $55^{-74}$. 
consolidate the empire internally. This coincided with their efforts to homogenize the multi-national and multi-ethnic population of the empire. St. Petersburg was eager to promote Orthodox Christianity in the Protestant and Muslim regions within its own borders. Simultaneously, it cut off contacts of non-Russians to the border regions outside the empire. With regard to the Muslim regions, this policy meant the reduction of any cultural, economic, and political contacts between Russian Muslims and the non-Russian Orient. ${ }^{27}$

According to Seydahmet, in the nineteenth century the Russian authorities were reluctant to issue passports to the Tatars, as they wanted to reduce the number of pilgrims going to Mecca. ${ }^{28}$ In this passage about the Muslim community in Russia, and their interactions and the obstacles to mobility they faced, Seydahmet's intention was not to promote pan-Islamic solidarity. Instead he tried to awaken the sympathies of Polish readers for the cause of an ethnic and religious community governed by a 'hostile regime.' Seydahmet, who spent almost a decade in Poland, had many Polish colleagues in Warsaw and was well acquainted with Polish history, their mentality, and the Polish image of Russia. Most of Polish society, particularly the representatives of the elder generation, had experienced the divisions of Poland and foreign rule, which finally ended in 1918 when the Polish republic was proclaimed. Because of this, Polish readers were particularly sensitive to the victim discourse of the non-Russian intellectuals.

\section{The Anti-communist Agitation of Hilal Munschi in Berlin}

In 1919 the Azerbaijani government sent around one hundred students to Europe, mostly to Germany, France, and Italy for university studies by offering them scholarships. ${ }^{29}$ Hilal Munschi was among those young Azerbaijani students whom the government in Baku sent to Germany. After Azerbaijan was occupied by the Bolsheviks in April 1920, Munschi decided to stay in Germany. He began with vigorous anti-communist propaganda activities. From 1920 he headed the bureau of the Müsavat Party ${ }^{30}$ in Berlin and, from 1923, he coordinated the

27 Daniel Brower, "Russian Roads to Mecca: Religious Tolerance and Muslim Pilgrimage in the Russian Empire," Slavic Review 55, no. 3 (1996): 567-584.

28 Sejdamet, Krym, 66.

29 "Azərbaycan Xalq Cümhuriyəti," in Azarbaycan Xalq Cümhuriyəti Ensiklopediyası, ed. Yaqub Mahmudov (Baku: EA neşriyat1, 2004), 1:75-76.

30 The Müsavat Party was founded in 1911 in Baku by a group of Azerbaijani political activists. During the independence period from 1918 to 1920, Müsavat was among the leading 
Azerbaijani Student Union. Still living in the German capital in 1930 Munschi published a monograph under the title Die Republik Aserbaidschan. Eine geschichtliche und politische Skizze [The Republic of Azerbaijan: A historical and political outline], ${ }^{31}$ in which he depicted the milestones of the Azerbaijani past and present by describing the history, national literature, and culture of Azerbaijan. The main aim of his writings was to present Azerbaijan as a country fighting for freedom and political sovereignty. He endeavored to generate sympathy and support for the Azerbaijani struggle for independence in Europe. In reaction to the ongoing nationalistic rhetoric in Germany, Munschi emphasized the particularistic and nationalistic character of the movement. ${ }^{32}$ Religious aspects did not play a central role in his propaganda work. He described, for example, the Azerbaijani people as having a strong national consciousness and compared them to non-Muslim societies such as Poland, Georgia, and other eastern European countries. He viewed them and Azerbaijan as advanced and civilized societies and described them as part of the family of "Kulturnationen." ${ }^{33}$ In contrast, he characterized the Soviet Union as backward and absolutist.

In his attempt to place Azerbaijan on an equal footing with European countries, Munschi also decried the negative stereotypes of the Orient that he had witnessed during his stay in Berlin. In this sense he rejected the orientalism that he found, for example, in the book Öl und Blut im Orient [Oil and blood in the Orient] written by Essad Bey. ${ }^{34}$ But even in this context Munschi considered the German reader and stressed that this book attacked not only Islamic tradition but national tradition and the religious rites of various societies, including that of the Jews and Christian peoples such as the Georgians, the Armenians, or Russians. Moreover, Munschi points out that the historical truth about Germany was not respected in Essad Bey's book. ${ }^{35}$ Munschi was careful to avoid giving the impression that Islam was an important aspect of Azerbaijani culture; thus he distinguished the country in an essential way from other European cultures.

political parties in the several governments in Baku. After the demise of the republic in 1920, Müsavat continued its existence in the exile, mostly in Iran, Turkey, Poland, and Germany until World War II. During the Perestroika (1985-1991), Müsavat was re-established in Baku. Hilal Munschi, Die Republik Aserbeidschan. Eine geschichtliche und politische Skizze (Berlin: Neudeutsche Verlags- und Treuhand-Gesellschaft, 1930).

32 Ibid., 1.

33 Ibid., 2.

34 Ibid., 3 .

35 Ibid., 4. 
Munschi pointed out that the important geopolitical position of Azerbaijan had motivated a variety of invaders in numerous conquests. In this context Munschi mentions the Arabs, who "occupied and devastated the country in the seventh century." ${ }^{36}$ According to Munschi, the Arabs governed Azerbaijan for three centuries and spread Islam in the region. It is interesting that he states that "Azerbaijanis were partly Christian, partly Zoroastrian before, but the ethnicity of the population and their language remained throughout the whole period constant: they were and continued to be Turks." ${ }^{37}$ It was not religion, but ethnicity and language that were considered the main factors defining Azerbaijani identity. On the one hand Munschi tried to show the ethnic and racial continuity of Azerbaijanis and their ancestors as Turkish, on the other hand he was also eager to adapt the Azerbaijani nation-building to European narratives. In this context he mentions intensive trade relations with European countries. On the other hand, the rule of Chingis Khan and Batu Khan, for example, is described as a yoke. ${ }^{38}$ About the Persian Shah Aga Mohammed Khan, Munschi writes that his cruel rule coincided with the development of "the Azerbaijani national consciousness that already at the end of the 18th century began to overcome the religious fanatism."39

In his account on Azerbaijani history Munschi mainly focused on the long struggle against Russian domination. Like the main anti-communist narratives of other Muslim intellectuals from the former Russian Empire Munschi describes in detail the Russian invasion of Azerbaijan in the eighteenth century and the annexation of the Muslim khanates in eastern Caucasia during the nineteenth century. Russian rule is described as a violation of Azerbaijani national independence, a menace to peace in the region, and as a suppressive regime. Munschi analyzes social resistance among the Azerbaijanis against the Russian authorities in terms of Kulturkampf and the national struggle by using the example and the terms of nation-building in Central Europe in the nineteenth century.

The Tsarist government always aimed at the suppression of the intellectual struggle of the Azerbaijanis. ...The foundation of any cultural association, including schools in mother tongue [non-Russian], libraries and national theatre were forbidden. The oppression had no limits: even the

\begin{tabular}{ll}
\hline 36 & Ibid., 9. \\
37 & Ibid. \\
38 & Ibid. \\
39 & Ibid., 11.
\end{tabular}


mosques could be built only at an appropriate distance, fixed by law, from the Orthodox churches. ${ }^{40}$

Furthermore Munschi mentions the persecutions of the Muslim clergy by Russian authorities, the suppression of Islam, and the spread of Christianity supported by the Holy Synod. But he softened his argument by writing that even more or less liberal Azerbaijani theologians were persecuted. ${ }^{41}$ At the same time the author also points out that the Azerbaijani media was critical towards the "anti-progressive Muslim clergy" and "confessional discord" (i.e., between Shī'ì and Sunnī). ${ }^{42}$ The satirical journal Mullah Nasreddin, ${ }^{43}$ for instance, fought "against reactionary forces" 44 and the religious fanatism of Persian Muslims. And another journal aimed at the "reform of the Arab alphabet and the woman question." 45 Munschi states that "nearly all the press of Azerbaijan asked for the equality of women"46 and that until 1920 Azerbaijan was the first Muslim country with broad rights for women that were no different than the women's rights of their Christian neighbors.

An example of the transfer of European and particularly German cultural notions can be seen in Munschi's description of Azerbaijani culture. He writes of the great epoch of literary and intellectual development in Azerbaijan in the middle of the nineteenth century and comes to the conclusion that "die großen Dichter und Denker" [the great poets and thinkers] ${ }^{47}$ were the real leaders of the Azerbaijani people. Moreover, Munschi portrays the Azerbaijanis as one of the leading Kulturnationen in the Orient. The Azerbaijani intellectual Mirza Fathali Akhundzade (1812-78), is described as "the greatest dramaturge not only in Azerbaijan but of the whole Islamic Orient." 48 Munschi thus promotes the idea of a modernizing cultural mission of Azerbaijanis in the Orient.

\footnotetext{
$40 \quad$ Ibid., 15 .

41 Ibid., 16.

42 Ibid., 23.

43 Mullah Nasreddin was a satiric journal published by Cəlil Məmmədquluzadə, an Azerbaijani writer, from 1906 till 1931. The language of the journal was Azerbaijani and was written first in Arabic, then in Latin, and finally in Cyrillic script. Mullah Nasreddin promoted the ideas of enlightenment among the Muslims of the Caucasus and was critical of the Muslim clergy and to some extent Tsarist policy in the region.

44 Munschi, Die Republik Aserbaidschan, 17.

45 Ibid., 19.

46 Ibid., 20.

47 Ibid., 15 .

48 Ibid.
} 
At the same time Munschi emphasizes the political character of the struggle for independence by the Muslims in the Caucasus. Even with regard to Chechen resistance in the northern Caucasus under the leadership of Shaykh Shāmil, Munschi only speaks of a "political struggle against the Russians," and does not mention his proclamation of jihad against the Russian occupier. ${ }^{49}$ Munschi deliberately used European ideas and categories to attract the attention of German readers to the Azerbaijani cause. He directly appealed to the reader's solidarity and empathy and adapted himself to the German Zeitgeist of the Weimar Republic when he writes: "The loss of the home country awoke the deepest patriotic feelings among all Azerbaijani people. The old spirit of the Khanates disappeared. The [Azerbaijani] nation feels united in the struggle against the northern enemy." 50

Like Seydahmet, Munschi adapted his text to the public it was written for. The argumentation and the choice of symbols and codes were selected deliberately. Islam was mentioned as an important distinction between Azerbaijanis and Russians, and to some extent as a source of civilization, theological discourse, and architecture. At the same time, both authors affirmed their nations' Europeanness and sense of belonging to the progressive community by depicting their national past by using the narative of European history.

\section{Zeki Velidi Toğan's Speech in Budapest}

Born in central Russia, Zeki Velidi Toğan taught at a traditional madrasa in Kazan, accompanied Russian orientalists from St. Petersburg University as interpreter during their excavations in Central Asia, and finally graduated in 1935 from the University of Vienna. He became an outstanding Turkish linguist and historian. Concurrent with his scientific work, Toğan was quite active as an advocate of Turkestani rights in Europe. In this context the presentation he delivered in Budapest in 1930 is of particular interest. His speech was published as a short brochure under the title Die gegenwärtige Lage der Mohammendaner Russlands [The present situation of the Muslims of Russia] in the same year. Zeki V. Toğan described the territories of Russian Tsardom and the Soviet Union inhabited by Muslims eastwards and westwards of the Caspian Sea, and pointed out that both Central Asia and Azerbaijan had been important

49 Ibid., 14.

$5^{\circ}$ Ibid., 14. 
cultural centers of Asia even before the Russian conquest. ${ }^{51}$ Like Munschi and Seydahmet, Toğan demonised the Russians and called Bolshevism a "destructive and cruel ideology." The narrative of Velidi Toğan was, however, quite ambiguous. On the one hand he sharply criticized Communist rule and its oppressive policy towards the Muslim community, on the other hand, he was, to some extent, optimistic about the future of Islam in the Soviet Union:

The fundament[als] of Islam as a religion and cultural power suffered a heavy strike under Bolshevik rule. The madrasas and the Sharia courts were closed. The fanatism of the clergy has suffered dramatically. Nevertheless the acceptance of a new religion or the revival of the preIslamic religion in Muslim Russia and other countries of the Orient is out of the question. Islam experienced a crisis but this concerned only its clerical traditions. ...Islam will only survive as a religion in a genuine spiritual sense. Perhaps it will be exactly the Bolshevik suppression that supports a new recovery of Islam. While Islam was suppressed, the Russian Muslims however hold on to their religion. ${ }^{52}$

Like Munschi, Toğan was quite critical of the Muslim clergy. At the same time neither the rituals of Islam nor the debate about its virtues were emphasized in his speech. The main aim of his presentation, delivered to an audience of orientalists and Turkologists, was to gain empathy among the Hungarians for the Turkestani cause. Toğan stressed the Turkishness of the Muslims in Russia and tried to instrumentalize the pan-Turanian ideas that were widespread in Hungary at that time. ${ }^{53}$

\section{Rasulzade's Writing in Poland}

Mehmed Emin Rasulzade was born and grew up in Baku during the oil boom at the turn of the century. Educated in a Russian-Tatar school in the Christian dominated, industrial metropolis of the Russian Caucasus, Rasulzade became an ardent socialist; he was soon persecuted by the Tsarist authorities for his political activities and had to escape to Persia in 1908. There he co-founded the

\footnotetext{
51 Validi Ahmedzeki [Zeki Velidi Toğan], Die gegenwärtige Lage der Mohammendaner Russlands (Budapest: V. Ahmedzeki, 1930), 3.

$5^{2}$ Ibid., 16.

53 See Joseph Kessler, Turanism and Pan-Turanism in Hungary 1890-1945 (Berkeley: University of California Press, 1967).
} 
socialist movement among Iranian intellectuals by editing the newspaper Irane-Nou. Rasulzade settled in Istanbul in 1911, again for political reasons, but was permitted to return to Baku after the amnesty in 1913. From 1918 to 1920 Rasulzade headed the Azerbaijani parliament, until the republic was occupied by the Bolsheviks. In the early 1920s he was a political exile, first in Turkey, and then in Poland from 1929.

In 1938, the Warsaw-based publishing house Azerbejdżańskie wydawnictwo narodowe [Azerbaijani national edition] published Rasulzade's monograph, Azerbajdżan w walce o niepodlegtość [Azerbaijan in struggle for independence]. The aim of the publication was to inform Polish readers about Azerbaijan, its geography, history, and culture. The author explains the etymology of the name Azerbaijan by analyzing the different theories of Russian and European orientalists, Arab and Azerbaijani historians. He describes the geography and population of Azerbaijan. The latter consists of Azerbaijani Turks, Rasulzade wrote, who were Muslims, and made up 75 percent of the population. ${ }^{54}$

Like Hilal Munschi, Rasulzade emphasized that "Azerbaijanis played an outstanding role in Persian and Turkish culture. Two of seven classic Persian poets, Nizami and Khagani, were originally from Azerbaijan, from Ganja and Shirvan," ${ }^{55}$ noted Rasulzade. Next to this text the author included a photo of the Shirvanshah Palace in downtown Baku and the pre-Islamic Zoroastrian temple Ateshgah in the suburbs of the Azerbaijani capital. In his short overview on the history of Azerbaijan, Rasulzade mentions the Islamization of the eastern Caucasus and Persia only briefly, though historically, it had a huge impact on the development of Azerbaijani culture. Writing about the ancient states in the eastern Caucasus, like the pre-Islamic Caucasian Albania ${ }^{56}$ and Media, Rasulzade stressed that the elites of Albania and its Sassanid rulers were Christian. ${ }^{57}$ The Arabs who conquered and Islamized the region are

54 Mehmed Emin Resul-Zade [Mehmed Emin Rasulzade], Azerbajdżan w walce o niepodlegtość (Warsaw: Azerbejdżańskie wydawnictwo narodowe, 1938), 26.

55 Ibid., 28.

$5^{6}$ Caucasian Albania was an ancient state and society of Caucasian and Iranian ethnic groups in the territory of modern Azerbaijan and northern Iran on the Caspian Sea shore. Albania was Zoroastrian and later Christian; after the invasion of Arabs to the Caucasus, some of its population became Muslim. In Persian and Arabic sources, Albania was called Arran. For more on Caucasian Albania see M.L. Chaumont, "Albania: An Ancient Country in the Caucasus," accessed 19 December 2013: http://www.iranicaonline.org/articles/ albania-iranian-aran-arm. 
mentioned in the same chapter, ${ }^{58}$ though Rasulzade did not write about the transfer of Islamic culture and religion. Like Toğan and Munschi, in several sub-chapters Rasulzade points to the animosity between Azerbaijanis and Russians, which he traces back to a twelfth-century Russian attack against the merchant city of Barda. ${ }^{59}$

Rasulzade uses Islam as the national and cultural identifier of the Muslim inhabitants of the Caucasus. "Muslims were seen in Russia always like 'citizens of the second class.' The population of Turkestan and the Caucasian Muslims were excluded...from military service, in order to prevent them from acquiring any warfare ability," ${ }^{\prime 0}$ Rasulzade claimed. Their religious belonging became a national/ethnic category.

One chapter of the book is devoted to the history of Azerbaijani folk culture. Rasulzade describes popular songs and the oral poetry of Azerbaijanis and stresses their Turkishness, trying to integrate them into the "Turkish speaking world."61 By analyzing the development of Azerbaijani national literature at the beginning of the twentieth century, Rasulzade argues that European national romanticism and to some extent national ideas were transferred from Turkey and became popular in Azerbaijan. As a result of these processes, "the press of Baku, which was initially under the religious-Islamic influence (religijno-islamistyczny ${ }^{62}$ ), was able to elaborate the national-cultural motives."63 Again Islam is presented within a national context, not as part of a larger transnational religious idea. ${ }^{64}$ The forerunner of this book was Rasulzade's article, "Rzeczpospolita Azerbajdżańska" [The republic of Azerbaijan], which was published in the Warsaw-based journal Wschód-Orient in 1930. This overview presented Azerbaijan by elucidating its culture, geography, past and present. "Azeris are a modern nation in the very sense of that word. Azerbaijan possesses its own literature, press, theatre, in sum everything that is called a national culture." ${ }^{65}$

In his analysis of the resistance of non-Russian nations against Moscow, Rasulzade differentiated between three groups: the rebels struggling against

\footnotetext{
$5^{8} \quad$ Ibid., $31-36$.

59 Ibid., 34 .

$60 \quad$ Ibid., 45 .

61 Ibid., 48-49.

62 The Polish notion islamistyczny can be translated into English nowadays as 'Islamist.' Rasulzade used it, however, as an adjective derived from the noun 'Islam.'

63 Resul-Zade, Azerbajdżan, 55 .

64 M.E. Ressul-Zade, "Rzeczpospolita Azerbajdżańska," Wschód-Orient 2 (1930): 26.

65 Ibid.
} 
the Bolsheviks, the emigrants outside the Soviet Union, and the opposition inside the Communist Party. Rasulzade emphasized the ethnic, cultural and religious differences between Russia and Azerbaijan. According to him the "Muslim and Turkish population of Azerbaijan"66 was against any ideology that had an all-Russian dimension, such as pan-Slavism or Bolshevism. He classified himself and his compatriots as not aligned with any Russian political party or movement.

\section{Haïdar Bammate's Publishing Activities in Lausanne and Paris}

Born in 1890 in the northern Caucasus to a turkophone Dagestani family, Bammate studied law at the University of St. Petersburg, and then worked for Tsarist authorities in Tbilisi and Kazan. After the Russian revolution he became the Minister of Foreign Affairs of a short-lived North Caucasian Republic of Mountaineers. After the fall of the northern Caucasus, Bammate migrated to France and actively spread anti-Soviet propaganda. He was supported first by Polish intelligence, and later, throughout the 1930s, by German and Japanese intelligence.

In 1919 Haïdar Bammate published in Lausanne a book entitled Le Problème du Caucase. ${ }^{67}$ In the principal chapter of the book Bammate develops the idea of the importance of the Caucasus, and particularly the Muslim Circassians, for Europe, as they serve as a bulwark against Communism. He points out that the Circassians supported Europe in the past by hindering "Asian attacks" coming from the East. In fact, Bammate repeats the arguments of many southeastern European intellectuals at the beginning of the twentieth century; these intellectuals stress the bulwark position of their countries by presenting them as safeguards of Europe against Islam.

In Paris and Berlin from 1934 to 1939 Bammate edited the Russian language journal Kavkaz, which emerged in German and French translation after 1937. This journal critically elucidated the political process in the Soviet Union and therefore contributed to European anti-communist thought. Moreover, the Kavkaz attracted attention for its pro-Turkish and pro-Kemalist point of view, although the Kemalist government in Ankara maintained good relations with

66 M.E. Ressul-zade, "Prądy narodowe w Azerbajdżanie Sowieckim," Wschód-Orient 1-2 (1935): 19 .

67 Haïdar Bammate, Le Problème du Caucase. Extrait de La Revue Politique Internationale $N$ de Novembre-Décembre 1918. Avec une carte ethnographique (Lausanne: La Revue politique interntionale, 1919). 
the Soviet Union. Haïdar Bammate wrote several editorials on the Near East and the historical and cultural bonds between the Caucasus and the Near East. Furthermore, Bammate was interested in the promotion of pan-Caucasian unity and integration. Being eager to involve Christian, especially Georgian and Armenian intellectuals, in his project of Caucasian confederation, ${ }^{68}$ Bammate abandoned other alternative ideas like, for example, pan-Islamic solidarity.

Throughout the 193os and during World War II, Bammate collected material for his long monograph on Islam. In 1946 his life's work was published in Lausanne under the title Visage de l'Islam. ${ }^{69}$ The aim of his book was to offer an overview of "the spiritual and intellectual values of Islam and to recall his [i.e., Islam's] contribution to the Occident." ${ }^{\prime 0}$ After elaborating on numerous works by French, Spanish, and Russian orientalists, Bammate delivers an interesting narrative of Islam's evolution from the rule of the Umayyad dynasty to World War II, paying particular attention to the development of Persian, Arabic, and Turkish literature, the sciences, and Islamic art. The chapter on art was written by his son Nadjmouddine (1922-85). $\cdot{ }^{71}$ While describing Persian and Arabic poetry, Bammate stresses their influence on European literature, mostly on Spanish and Provencal poetry. Quoting extensively from the works of Ernest Renan and other French orientalists, Bammate simultaneously criticizes some of the stereotypes about the Near East and Islam in their works. Bammate's 500-page book offers a profound overview on the history of Islam, its contribution to world culture and civilization "au grand public," for a broad public. Bammate pleads for Christian-Muslim dialogue. According to him, there is a strong similarity between the moral virtues and values of the Christian and Islamic civilizations. The expanded version of Visages de l'Islam was republished in 1959 and was well-received among Francophone Algerian ${ }^{72}$ nationalists and by readers in Turkey. ${ }^{73}$

68 Gaidar Bammat, "Nashi zadachi," Kavkaz (Le Caucase) Organ nezavisimoi natsional'noi mysli 1 (1934): $3^{-5}$.

69 Bammate, Visages de l'Islam.

$70 \quad$ “...il nous a paru utile de soumettre aux lectuers un apercu rapide mais assez varié des valeurs spirituelles et intellectuelles de l'Islam et de rappeler son apport à l'Occident." Bammate, Visages de l'Islam, xiii.

71 The chapter was published in the same year as a separate booklet, also in Lausanne.

72 Sadek Sellam, "Le FLN vu par l'écrivain Malek Bennabi (1905-1973): Les relations malaisées d'un penseur non conformiste avec le pouvoir algérien naissant," Guerres mondiales et conflits contemporains 4, no. 208 (Oct.-Dec. 2002), 136; DOI: 10.3917/gmcc208.0133.

73 Throughout the 1960 and 1970s, two different translations of Visages de l'Islam were published in Istanbul and Ankara. 


\section{Conclusion}

Cafer Seydahmet, Zeki Velidi Toğan, Hilal Munschi, Haïdare Bammate, and M. Rasulzade like many other Azerbaijani, north Caucasian, and Tatar intellectuals living in exile in interwar Europe conducted anti-communist propaganda activities in France, Poland, and Germany. They wrote for a variety of European media and published books on the history and the socio-political situation of their countries of origin. They were eager to make European readers aware of the culture, the recent developments, and the current political problems in the Soviet Caucasus and the Crimea, and Islam played a significant role in their argumentation. Because they were based in Christian countries and addressing primarily Europeans, these non-Russian Muslim émigrés were quite cautious with regard to their contributions on Islam in the European media during the 1920s. Perhaps this was an attempt to avoid any impression of being 'religious Muslims' among European intellectuals and politicians. It can be freely assumed that these Azerbaijani and Tatar intellectuals presented themselves and their countries of origin as less Islamic than they were in reality. The aim of these anti-communist émigrés was to obtain European support in their confrontation with the Soviet Union; they clearly shared the impression that the West would be reluctant to support Islamic societies.

In this context it is useful to mention the similarities between the texts written by these Muslim intellectuals in exile in Europe and Turkey in the interwar period. Islam, its rituals, customs, traditions, and institutions were only depicted marginally, even in Turkish publications, which emerged in Istanbul during the 1920 s and 1930s. This was because of Mustafa Kemal Atatürk's rigorous secularist policies during this period. The differences in the Turkish texts written by Seydahmet, Rasulzade, and Zeki Velidi Toğan relates to their appeals to pan-Turkish solidarity and Turkishness, which were much less articulated in the texts they published in Polish, French, and German.

Islam was treated as an essential subject in the books and articles of Rasulzade, Bammate, Munschi, Seydahmet, and Zeki Velidi Toğan, though they belonged to a secular generation of Eurasian intellectuals of Muslim origin, who shared the opinion that nationalism was much more important for the mobilization of their ethnic groups than the idea of a supranational Islamic community (umma). While the representation of Islam in interwar Europe was not a life vocation for these Muslim intellectuals from Russia living in European exile, this changed considerably after World War II. 


\section{Bibliography}

\section{Primary Sources}

Bammate, Haïdar. Le Problème du Caucase. Extrait de La Revue Politique Internationale $N$ de Novembre-Décembre 1918. Avec une carte ethnographique. Lausanne: La Revue Politique Internationale, 1919.

— [Bammat, Gaidar]. "Nashi zadachi." Kavkaz (Le Caucase) Organ nezavisimoi natsional'noi mysli 1 (1934): 3-5.

— [Bammate, Haidar/Georges Rivoire]. Visages de l'Islam. Lausanne: Payot, 1946. Essad Bey, Mohammed. Eine Biographie. Berlin: Kiepenheuer, 1932.

Munschi, Hilal. Die Republik Aserbaidschan. Eine geschichtliche und politische Skizze. Berlin: Neudeutsche Verlags- und Treuhand-Gesellschaft, 1930.

Resul-Zade, Mehmed Emin [Mehmed Emin Rasulzade]. Azerbajdżan w walce o niepodlegtość [Azerbaijan in struggle for independence]. Warsaw: Azerbejdżańskie wydawnictwo narodowe, 1938.

—. "Prądy narodowe w Azerbajdżanie Sowieckim." Wschód 1-2 (1935): 18-33.

"Rzeczpospolita Azerbajdżańska." Wschód 2 (1930): 26-29.

Seydahmet, Cafer. Bazı hatıralar. Istanbul: Emel, 1993.

[Sejdamet, Dżafer]. Krym. Przeszłość, teraźniejszość i dążenia niepodlegtościowe tatarów krymskich [Crimea. Past, present and independence aspirations of the Crimean Tatars]. Warsaw: Instytut Wschodni, 1930.

Validi Ahmedzeki [Zeki V. Toğan]. Die gegenwärtige Lage der Mohammendaner Russlands. Budapest: V. Ahmetzeki, 1930.

\section{Research Literature}

“Azərbaycan Xalq Cümhuriyəti." In Azərbaycan Xalq Cümhuriyati Ensiklopediyası, edited by Yaqub Mahmudov et al. Baku: EA nəşriyyatı, 2004.

Bowman, Inci. "Cafer Seydahmet Kirimer (1889-1960)." Online: International Committee for Crimea. Accessed 21 June 2013: http://www.iccrimea.org/historical/ cskirimer.html.

Brower, Daniel. "Russian Roads to Mecca: Religious Tolerance and Muslim Pilgrimage in the Russian Empire." Slavic Review 55, no. 3 (1996): 567-584.

Gasimov, Zaur. "Bolshevik Post-Colonialism, Eurasian Perspective and Entangled Intellectuals. Russian Debates on Spengler in the Interwar Period." In Oswald Spengler als europäisches Phänomen. Der Transfer der Kultur- und Geschichtsmorphologie im Europa der Zwischenkriegszeit 1919-1939, edited by Zaur Gasimov and Carl A. Lemke Duque, 67-83. Göttingen:V\&R, 2013.

and Wiebke Bachmann. "Für nationale Ehre, Freiheit und Selbständigkeit! Die publizistische Aktivität der aserbaidschanischen Exilanten in Berlin in der 
Zwischenkriegszeit." In Brücken bauen-Analysen und Betrachtungen zwischen Ost und West. Festschrift für Leonid Luks zum $6{ }_{5}$ Geburtstag, edited by Jürgen Zarusky, et al., 277-294. Stuttgart: Ibidem Verlag, 2012.

. "Vom Panslavismus über den Panturkismus zum Eurasismus. Die russischtürkische Ideenzirkulation und Verflechtung der Ordnungsvorstellungen im 20. Jahrhundert." In Post-Panslavismus. Slavizität, Slavische Idee und Antislavismus im 20. und 21. Jahrhundert, edited by Agnieszka Gąsior, Lars Karl, and Stefan Troebst, 450-474. Göttingen: Wallstein Verlag, 2014.

Kazemzade, Firuz. The Struggle for Transcaucasia, 1917-1921. Westport, ст: Hyperion, 1981.

Kessler, Joseph. Turanism and Pan-Turanism in Hungary 1890-1945. Berkeley: California University Press, 1967.

Kurıml, Hakan. National Movements \& National Identity among the Crimean Tatars (1905-1916). Leiden: Brill, 1996.

Kornat, Marek, ed. Ruch prometejski i walka o przedbudowę Europy Wschodniej (1918-1940) [Promethean movement and the struggle to reshape Eastern Europe (1918-1940)]. Warsaw: Instytut Historii PAN, 2012.

Özcan, Ufuk. Ahmet Ağaoğlu ve Rol Değişikliği: Yüzyıl Dönümünde Batılı Bir Aydın. Istanbul: Kitabevi Yayınlan, 2010.

Rutherford, Jonathan. "The Third Space. Interview with Homi Bhabha." In Identity: Community, Culture, Difference, edited by Jonathan Rutherford, 207-221. London: Lawrence and Wishart, 1990.

Sellam, Sadek. "Le FLN vu par l'écrivain Malek Bennabi (1905-1973): Les relations malaisées d'unpenseur non conformiste avec le pouvoir algérien naissant." Guerres mondiales et conflits contemporains, 4, no. 208 (October-December 2002): 133-150. DOI: 10.3917/gmcc.208.0133.

Weeks, Theodore R. "Russification/Sovietization.” In European History Online (EGo). Mainz: Institute of European History (IEG ), 2010. Accessed 2 December 2013: http:// ieg-ego.eu/en/threads/models-and-stereotypes/russification-sovietization. 


\section{Index}

AAII

See Ahmadiyya movement ABC Sevilla (newspaper) 155

'Abd al-Karīm al-Khaț̣ābi,

Muhammad b. 158

'Abd al-Qādir 90

'Abd al-Salām al-Salīm, Abū l-Makarim

Muhammad 66

Abdel Razaq, Salah 88

'Abduh, Muhammad 51

Abdul-Ghani, Khwaja 78

Abdullah, S.M.

body of thought of 26

invitation of Arslān $\quad 65$

travels of 74

views on 28

Abdul-Majid, Mawlana $\quad 61,78$

Aboe Bakar Djajadiningrat $\quad$ 95-96, 102

Abu Inan Faris 109

Achcar, Gilbert 23

Addison, James Thayer 49

al-Afghānī, Jamāl al-Dīn $\quad 54$

Agai, Bekim $\quad$ 1-17

Ağaoğlu, Ahmet 208

Ahmad, Mirza Ghulam

conflicts with, Rị̣ā $\quad 5^{1-52}$

establishing Ahmadiyya movement 47

as Messiah $\quad 48,57,67$

as reformer $48,49,55,67$

views on

of al-Khatịb $\quad 61$

of Sadr-ud-Din 67

Ahmadiyya Anjumani-Isha'ati-Islam (AAII)

See Ahmadiyya movement

Ahmadiyya movement

in Berlin

conversion process of $\quad 33-34,39$

converts attracted to $\quad 29$

leadership of

Ali, Muhammad 27, 48

Sadr-ud-Din, Khwaja $\quad 24-25$

mission approaches of $\quad 21-22,28-29$

mosque of $20,24,39-40,65,67$

and Muslim modernity $\quad 10,41,42-43$

views on, of Rahman 39-41 competition with, Sheldrake $\quad 71-73$

contacts of, Perhimpoenan

Indonesia 140

von Ehrenfels and $\quad 73-74,75$

in Europe 10, 47-48

financial integrity of 71

Lahore branch of

Arslān's correspondence with $\quad 67$

conflicts with, Qadiyani

movement $\quad 48-49$

establishment of 47

philosophy of 25

views on, of al-Khidir 66

in London

Qadiyani branch of 48

Working mission $\quad 48$

in the Netherlands $\quad$ 139-140

Qadiyani branch of

conflicts with, Lahore branch of 48-49

criticism on $\quad 63-64$

and death Rị̣ā $\quad$ 78-79

Qurān translation of 57

Sheldrake and $\quad 69-70$

in UK, views on, of Islamic converts

49

in USA 61

usefulness/uselessness of 64

views on

of Arslān $\quad 60-61,66-67$

in al-Fath $\quad 59-62,66,67,82$

in Hadramaut $\quad 64-65$

of al-Hilāl̄̄ $\quad 63-64,67-68,71-72$

of al-Khațīb $64,78,79$

of Muhib 59-60

of al-Nadwī 64

of Riḍā $\quad 57-5^{8}$

of Salafĩ movement $\quad 50,62-63,82$

of Sheldrake 82

of Simpson 74

Akhundzade, Mirza Fathali 215

al-Alawi, Ahmad 113 n24

al-Azhar (religious institution) 57, 59, 93

Albéniz, Ruiz (El Tebib Arrumi) 153, 162

Alexander III, of Russia $\quad 207$

Algeria 112 
Algermissen, Konrad (Giesel, Konrad) 34

Ali, Abdullah Yusuf 48

'Ali, Maḥmūd Ḥamdī $\quad$ 76-77, 78

'Ali, Muhammad

leadership of Ahmadiyya mission

leanings towards fascism 27,43

publications of, al-Bayān fil-rujū' ilā

l-Qur'ān 78

Qurān translation of 57

and Sheldrake 73

views on, of Arslān $\quad 67$

'Alī, Zākī 74, 75

Allanson-Winn, Rowland (Headley, 5th

Baron)

See Headley, $5^{\text {th }}$ Baron

Amazyān, Mohammed 174

Amsterdam

Chinese communities in $\quad 136$

Indonesian Muslim communities in 128

Anselm of Turmeda, Fray ("Brother") 88

anti-Ahmadiyya campaign

brochures by Mansur Rifaat 65

in Egypt $\quad 5 \mathbf{1}^{-52}, 67-68$

in India $\quad 5^{0}$

in Indonesia $\quad 64-65$

world wide 77

anti-colonial movement $\quad 141$

anti-communist propaganda $\quad 212,220,222$

anti-Semitism 38

architecture

of Crimea 211

of Morocco 109-110

of Paris Mosque 106, 108-109

Arslān, Shakīb

contacts of

Hadj 141

al-Ḥusaynī $\quad 138$

Perhimpoenan Indonesia

members 142, 145

Riḍā 138

and European Muslim Congress 1935, 10, 138-139

views of

on Ahmadiyya movement $\quad 60-61$, 66-67

of 'Ali, Muhammad 67

views on

in Hadramaut $\quad 64-65$

of Kiram Hishmat 65 visits to Ahmadiyya mosque Berlin $\quad 65,67$

Asad, Muhammed (Weiss, Leopold) 30-31, 88-89

Atatürk, Mustafa Kemal $\quad$ 208, 222

Azerbaijan

equality for women in $\quad 215$

etnicity of inhabitants $\quad 214$

folk culture of 219

invaders of 214

literary and intellectual development

in 215,218

Muslim/Tartars in

émigré intellectuals from

See Ağaoğlu, Ahmet; Munschi,

Hilal; Muslim/Tartar émigrés;

Rasulzade, Mehmed Emin

Sovietization of 205

struggle against Russian domination 214-216, 219-220

views on

of Munschi 213, 214-216

of Razulzade $\quad 218-220$

Azerbaijani Student Union $\quad 213$

Azerbajdżan w walce o niepodlegtość

(Rasulzade) 218-220

Azerbejdżańskie wydawnictwo

narodowe 218

al-Azhar, Shaykh

See Maḥmūd, 'Abd al-Ḥalīm

baboes

See domestic workers

Bachmann, Wiebke $\quad$ 16-17, 204-224

Baig, Mirza Ali Ahmad 139, 144

Bairašauskaitė, Tamara $\quad$ 179, 202-203

al-Bakrī, Sayyid Iḥsān 55

Balfour, Sebastian $\quad 160$

Bamford, Amina 54

Bammate, Haïdar

editor of Kavkaz 220-221

education of $206,207,220$

linguistic compentences of 208

political engagement of 208,220

publications of 220, 221

views of

on Caucasus 220-221

on Islam 221

al-Banna, Hasan 66 n62, 82

Banning, Khalid 32,34 
Batu Khan 214

al-Bayān fil-rujū’ ilā l-Qur'ān ('Ali,

Muhammad) $\quad 78$

Beetem, Mohammad Ali van

See van Beetem, Mohammad Ali

Beigbeder, Juan Luis 154

Ben Ali (Moroccan vizier) 168-169

Ben Ghabrit, Abdelqader

See Benghabrit, Si Kaddour

Benghabrit, Si Kaddour

and building of Paris Mosque 109, 113

and Muslim cemetery 118-119

relation with French state 123

and Society of Habous and Sacred Places

of Islam 107

views of, on Islam and French

civilization 108

Berlin

Ahmadiyya movement in

conversion process of $\quad 33-34,39$

converts attracted to $\quad 29$

leadership of

Ali, Muhammad $\quad 27,48$

Sadr-ud-Din, Khwaja 24-25

mission approaches of 21-22, 28-29

mosques of $20,24,39-40,48,65,67$

and Muslim modernity $10,41,42-43$

views on, of Rahman $\quad 39-41$

as center of European modernity $\quad 19-20$

and globalization $\quad 18$

Islamic converts in

and Ahmadiyya conversion process

33-34, 39

and Ahmadiyya movement $\quad 28-29$

conversion photographs of $\quad 33-35$

with Eastern European

background 31

and IBG 28-29

and Islam Institute $\quad 29$

and Islamia 29

members of Islamia 30

and Muslim émigrés 33

policies of Islam Institute towards 32

reasons for conversion $\quad 30-31,34-36$

reconstructing lives of $22,30,3^{1}$

rules for $39-40$

social and political range of 22

Muslim communities in

after World War I 30 and anti-Semitism $\quad 38$

cultural backdrop of $\quad 20-21$

and different ways to modernity $\quad 42$

Islam Institute as anchor of 32

leadership of $\quad 23-26$

leanings towards fascism 23,27

mosques of $20,24,39-40,48,65,67$

Nazism and 26-27

organizations of $23,25^{-26}$

Muslim missions in

of Ahmadiyya movement

See above

Islamia $\quad 29-30$

of Sufi movement $\quad 25^{-26}$

tracing of activities of 22

See also Deutsch-Moslemische

Gesellschaft e.V.; Islam Institute;

Islamische Gemeinde zu Berlin e.V.

Muslim modernity in

and Ahmadiyya movement 10, 41, 42-43

and Ehrenfels $\quad 36,38$

and Fisher, Faruq H. $\quad 38-39$

and Nazism $\quad 38-39$

and Tschelebi $\quad 31-32$

Muslim/Tartar émigrés in

duration of stay of 32

and IGB 22

views of, on local Islamic con-

verts $33,39-41$

want of own mosque 40

See also Munschi, Hilal

pow camps outside 20

Russian refugees in $\quad 19-20,30$

Bey, Es[s]ad (Nussimbaum, Levi)

publications of 213

reasons for conversion 30,31

Bhopali, Mawlana Barkatullah 141

Blasco, García $\quad 157$

Blum, Léon 121

Bolshevism 217, 220

Bond van Nationalisten $\quad 131$

Bose, Subha Chandras

body of thought of 28

leadership of

IG B $\quad 27-28$

Islam Institute $\quad 28$

views of, on Abdullah, S.M. $\quad 28$

Bou Inania (Fez) 109 
Brigade nord-africaine (North African

Brigade) 114, 115-117

British India, liberation movements in 21, 27,29

British Muslim Society $\quad 48,79$

Browne, Hajj Abdullah $\quad 51$

Budapest, Toğan's speech in $\quad 217$

Burckhardt, Johann Ludwig 90

Burhan el Din, Shaykh-al-Jawi 144

Burton, Richard Francis 90

al-Busnawī, Muḥammad Saljaq $\quad 75$

Cabanellas, Miguel $\quad 168$

Cairo

Ahmadiyya movement in 65

Muslim communities in anti-Ahmadiyya campaign of 50 Jawi

arrival of 143

contacts with the

Netherlands 143-144

Catholicism

conversions to 166

in Germany 19

Caucasus

and Near East 221

views on, of Bammate $\quad 220-221$

cemeteries

Muslim

in Lithuania 193, 203

in the Netherlands $\quad 132$

in Paris 118-119

in Spain

Granada 175

for Moroccans dying in Civil War 164-165

Talavera $\quad 165$

Ceuta, mosque in $\quad 15^{2}$

Chaleckas, Aleksandras $\quad$ 196, 197

Chingis Khan 214

Christian missions

in Muslim world 63

in USA 61

Christian Occident (Christliches

Abendland) $\quad 19$

Christianity

and Communism 160

conversion to $51,184 \mathrm{nl} 3$

and Islam $36,41,42,53$
Christian-Muslim dialogue 221

Christliches Abendland (Christian

Occident) 19

Chung Hwa Hui 134

CIAM (Interministerial Commission for

Muslim Affaires) $\quad 118$

Circassians 220

Cobbold, Evelyn $\quad 76$

Colonial Exposition (1922; Marseille) 111

Colonial Exposition (1931; Paris) 111

Comintern 141, 142

Comité de Defense de la Race Nègre 141

Communism

destruction of religion by 160

Prometheism and 209-210

Communist International Red Aid 141

concubines 101

continuation, and conversion 35

conversion narratives 11

Bamford, Amina 54

Gohl, Saffiah Irma 35

Headley, 5th Baron 53

Marcus, Hamid $\quad 35^{-} 36$

conversions

to Catholicism, of Moroccan

Muslims 166

to Christianity, of Muslims/Tartars $\quad 5^{1}$, $184 \mathrm{n} 13$

definition of 33

to Islam

of Bey $30,3^{1}$

forced 89

of Headley $53,56,76$

of intellectuals $88-90$

out of convenience $\quad 89-90$

out of personal free will $\quad 88-89$

of Sheldrake 71

of Simpson 70

sincerity/insincerity of $53,56,71,76$, 89

of Snouck Hurgronje $\quad$ 90, 91-93,

101-102

of van Beetem 130, 144

See also conversion narratives; Islamic converts

Córdoba, Fernando Fernández de 173

Cowan, David/Dawud $\quad 82-83$

Crimea

Muslim/Tartar communities in 
architecture of 211

competence in Qur'an reading 211

émigré intellectuals from

See under Muslim/Tartar émigrés;

Seydahmet, Cafer

limiting of mobility of 212

mosques of 211

and Russan Tsardom 211-212

views on, of Seydahmet $\quad 210-212$

Sovietization of 205

Dār al-Da'wa wa-l-Irsshād (missionary school) 54

Darmestatter, James 208

Davidson, Naomi $\quad$ 14-15, 105-124

Delft, Muslim community in 128

Der Islam: Ein Wegweiser zur Rettung und zum Wiederaufbau (Islam: A guide for rescue and restoring; journal) 24

Deutschheit (German-ness) 19, 21

Deutsch-Moslemische Gesellschaft e.V.

(German Muslim Society; DMG)

fusion with Islam Institute 33

leadership of

Abdullah, S.M. $\quad 26,28$

Marcus, Hamid 35

leanings towards Nazism $\quad 27$

photograph of $4 \mathbf{1}$

views on, of IGB $\quad 27-28$

Diario Marroquí (journal) 152

Dinet, Étienne 83

al-Diya (magazine) 64

Djajadiningrat, Aboe Bakar 95-96, 102

Djam'iat al Chairijah 143,144

DMG

See Deutsch-Moslemische Gesellschaft e.V.

domestic workers

Indonesian Muslim, in the

Netherlands $\quad 128,130,133,134-135$

Doumergue, Gaston

views of

on French and Muslim elites $107 \mathrm{n} 4$

on Islam and French civilization $\quad 108$

Dutch East Indies

See Indonesia/Dutch East Indies

Dybe, Anton 30

Egypt

anti-Ahmadiyya campaign in $\quad 51-52,67-68$ circulation of Ahmadiyya's Qur'ān

translation in 57

Headley, Kamal-ud-Din and Mohye in $55-56$

See also Cairo; al-Fath; al-Manār

Ehrenfels, Rolf Umar (von) 36, 37, 38

and Ahmadiyya movement $\quad 73-74,75$

travels of 74

views on

$$
\begin{array}{ll}
\text { of al-Hilālī } & 74 \\
\text { in The Light } & 74
\end{array}
$$

El Tebib Arrumi 153

emigrants

See Muslim/Tartar émigrés/emigrants émigrés

See Muslim/Tartar émigrés/emigrants

En Terre d'Islam (journal) $\quad 110$

Encyclopaedia of Islam (Snouck Hurgronje) 91

Essafi, Ahmed 142

'ethical' tradition, among Dutch imperial

historians 129, 135

ethnic groups, and changing of borders $\quad 187$

Europe

Ahmadiyya movement in $10,47-48$

Islamic converts in

activities in pan-Islamic

networks $49-50$

intellectuals $88-90$

See also Snouck Hurgronje,

Christiaan

role of

in connecting East and

West $81-82$

in Salafì-Ahmadiyya disputes $5^{0}$, $81-82$

set of rules for $\quad 25$

views on, of al-Hilālī 63

Muslim communities in, and contacts

with Perkoempoelan Islam $\quad$ 137-138

Muslim missions in,

non-Ahmadiyya $\quad 75^{-76}$

Muslim modernity in

and Ahmadiyya movement 10

and Nazism 12

Muslim/Tartar émigrés in

See under Muslim/Tartar émigrés

political destabilization in 18

Promethean networks in 209-210

spiritual vacuum in 19 
"Europe from the Outside" research group 3 European Muslim Congress (Geneva; 1935)

$$
\text { 2, 10, 138-139 }
$$

Faith Organization of Lithuanian

Mohammedans 191

al-Fath (journal) $\quad \mathbf{8 0}-\mathbf{8 1}$

contributors to 59,67

mouthpiece of Salafissm $\quad 5^{0-51,} 5^{8-59}$

readership in London 59

views in

on Ahmadiyya movement $\quad 49,59-63$, $66,67,82$

on non-Ahmadiyya European missions $75^{-76}$

on Sheldrake $\quad 68-69,72-73$

on Woking mission $\quad 76-78$

views of, on Ahmadiyya movement 83

Figueras, García, views of, on Nationalist administration in Morocco 153

Fischer, Faruq H. $\quad 37,38-39$

Fox, Rosalinda 155

France

Algerians in 115,123

Muslim policies of $113,115,123$

Muslims/Tartars in

émigré intellectuals

See Bammate, Haïdar

Paris as heart of empire of $\quad 112-113$

popular press in 110-111

separation of church and state in 113

See also Franco-Muslim Hospital (Paris);

French Islam; Paris

Franco, Francisco

as protector of Islam 155

sponsoring of Hajj $\quad$ 154-155

views of

on Communism's destruction of

religion 160

on conversion of Moroccan

Muslims $\quad 166$

on religiousness of Moroccans 153

Franco-Muslim Hospital (Paris) 111, 114, 115, $118,119-122$

French Islam

collaborative vision of $\quad 107-108$

as compatible with republicanism $\quad 108$

government support for 114

origins of, in Morocco $\quad$ 107-108 paradox of 107, 114

Paris Mosque as embodiment of 113,122

and racialization $\quad 105^{-106}$

views on

of Benghabrit 108

of Doumergue $107 \mathrm{n} 4,108$

Fuelling, Mubarak 79

"future man," $36,38-39,41$

Gasimov, Zaur $\quad$ 16-17, 204-224

Gatot $141 \mathrm{n}_{5} 6$

German Federal Ministry of Education and

Research (Bмвғ) 3

German-ness (Deutschheit) 21

Germany/Weimar Republic

Ahmadiyya movement in conversions made by 67 two branches of 49

National Socialism/Nazism in $\quad 12,21,23$, 26-27, 28, 38-39, 43

official religion in 19

Ottoman Empire as ally of $\quad 20$

political destabilization in $\quad 18-19$

spiritual vacuum in 19

See also Berlin

Gérolami, Adolphe $\quad$ 115-116, 117, 118

gestalt therapy 36,38

Ghadar Party 141

Ghani, Khwaja Abdul $\quad 58$

Giesel, Konrad (Algermissen, Konrad) 34

Gift for the Intelligent to Confute the People of the Cross (al-Mayyurqī) 88

Gilham, Jamie 49

globalization 18, 19

Godin, Pierre $112,115^{-116,118}$

Gohl, Saffiah Irma 35

Goldziher, Ignaz 93

Göritz, Käthe 30

Granada, Muslim cemetery in $\mathbf{1 7 5}$

Gregory XVI, Pope 90

Ḥaddād, 'Azīz b. 93

Hadj, Messali 141-142

Hadramaut (newspaper) 64-65

Ḥāfiz Wahba, Shaykh $\quad 60,61,77$

The Hague

Muslim communities in

Indonesian 146 
and aid to members of

Perkoempoelan Indonesia 134-135

cemeteries for 132

founding of Perkoempoelan

Islam 130, 132

during Great Depression 134

mosque of 130-131, 139

origins of 128

Hakim, Mohammed Ibn Azzuz $\quad 160$

al-Hamdu li-Llāh hadhihi hayātī

(Maḥmūd) 83

Hasan Muṣțafā, Hājjī 96-97, 101

Hatta, Mohammed 129, 141, 144

Haut-Comité Méditerranéen (High

Committee on the Mediterranean;

HCM) 121

al-Hazarwī, Muhammad 'Abd al-Salām

Salīm $\quad 78$

Headley $5^{\text {th Baron (Allanson-Winn, }}$

Rowland)

conversion of

reasons for $5^{6}$

sincerity/insincerity of $53,56,76$

death of 79

description of 56

as exemplary Muslim 83

financial integrity of 71

founding of British Muslim Society 48

hajj of $55^{-56}$

people denouncing relationship with 79

and permissions to build new

mosque 60

and Woking mission $\quad 82$

High Committee on the Mediterranean

(Haut-Comité Méditerranéen; HCM) 121

al-Hilālī, Taqīl-Dīn

views of

on Ahmadiyya movement $\quad 63-64$, 67-68, 71-72

on von Ehrenfels 74

on Sheldrake 71

histoire croisée $\quad 3-4,6$

Hoeftmann, Erna $30,3^{2}$

Hoffmann, Emina 32

Hoffmann, Walther $\quad 30,32-33$

hospitals

in Paris $111,114,115,118,119-122$

in Spain

for Moroccan Muslims 165-171 and alcohol consumption $\quad$ 169-170

Ben Ali's views on 168-169

complaints against $\quad 170-171$

dietary needs of inmates 168

and "Moorish cafés," 168, 169

organization of 168-169

positive memories of inmates of 171 proselytizing attempts at $\quad 166-167$ at Salamanca 169

at Villafranca de los Barros $\quad$ 170-171

at Zaragoza 167-168

Hungary, pan-Turanian ideas in $\quad 217$

al-Hurriyya (daily) 159

Husayn, al-Khiḍr 66 n62

al-Ḥusaynī, Amīn $\quad 61,138$

iboes

See domestic workers

IG B

See Islamische Gemeinde zu Berlin e.V.

L'Illustration (journal) 111

India

anti-Ahmadiyya campaign in 50

See also British India; Lahore

Indian National Congress 141

Indische Vereeniging ('Indies'

association) $\mathbf{1 2 9}$

Indonesia Merdeka (journal) 140, 143

Indonesia/Dutch East Indies

anti-Ahmadiyya campaign in $\quad 64-65$

colonial Islam policies of 91

during Great Depression 134

living with indigenous concubines in 101

See also Hadramaut

Institute of Oriental Studies (Instytut

Wschodni) 209

intellectuals

in Europe

Christian

conversion to Islam of

and attacks on old faith 88

out of convenience $89-90$

out of personal free will $\quad 88-89$

See also Snouck Hurgronje,

Christiaan

Tartar émigré

anti-communist actvities of 16 , 212, 222

anti-communist propaganda by 222 


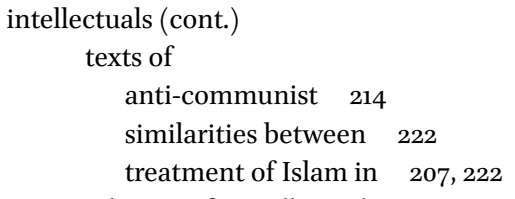

See also specific intellectuals

Interministerial Commission for Muslim

Affaires (CIAM) $\quad 118$

Irane-Nou (newspaper) 218

Iran/Persia

culture of 208

émigré intellectuals in,

Rasulzade 217-218

Iranshar, Hosseyn Kazemzadeh $\quad 26$

Islam

anti-sectarianism and 70,74

and Christianity $36,41,42,53$

as Christianity with additions $\quad 53-54$

Communism and 160

conversions to

forced 89

of intellectuals $\quad 88-90$

See also Snouck Hurgronje,

Christiaan

out of convenience $89-90$

out of personal free will $\quad 88-89$

sincerity/insincerity of $53,56,71,76,89$

French vision of

See French Islam

in Lithuania, Grand Duchy 181-183

multiplicity of 114

in Russia/Soviet Union

suppression of $211-212,214-215,217$, 219

views on, of Toğan 217

views on, of Bammate 221

Islam Archive (Berlin) 25, 31

"Islam in Interwar Europe and European

Cultural History" (2012) 2-3

Islam in Interwar Europe (Clayer \&

Germain) 1

Islam Institute (Berlin) 25, 28, 29, 31-33

Islamia $\quad 29-30$

Islamic converts

in Berlin

and Ahmadiyya conversion process

33-34, 39

and Ahmadiyya movement $\quad 28-29$

conversion photographs of $\quad 33-35$ with Eastern European

background 31

and IBG 28-29

and Islam Institute $\quad 29$

and Islamia 29

members of Islamia 30

and Muslim émigrés 33

policies of Islam Institute towards 32

reasons for conversion $\quad 30-31,34-36$

reconstructing lives of $22,30,31$

rules for $39-40$

social and political range of 22

in Europe

activities in pan-Islamic

networks $49-50$

intellectuals 88-90

See also Snouck Hurgronje,

Christiaan

role of

in connecting East and

West $\quad 81-82$

in Salafì-Ahmadiyya disputes 50 , 81-82

set of rules for 25

views on, of al-Hilālī 63

in UK, views of, on Ahmadiyya

movement 49

views on

in al-Manār 53

of Salafī movement $\quad 51$

See also conversion narratives;

conversions

The Islamic Review (periodical) 54, 61, 77

Islamische Gemeinde zu Berlin e.V. (IGB)

converts attracted to 29

distancing from Ahmadiyya movement

79,81

foundation of 32

fusion with Islam Institute 33

leadership of

Bose, Subha Chandras $\quad 27-28$

Kheiri, Abdul Jabbar $\quad 23-24$

mission approaches of $\quad 21-22,28-29$

opposition to renewal $39-41,42$

revival of $27-28,33$

and rules for converts $\quad 39-40$

Tchelebi breaking with 32

views of, on DMG 27-28

Islamische Kulturbond (Vienna) 73-74, 75 
James of Compostela, Saint 174

Jawi community Cairo $\quad$ 143-144

Jogaila, Grand Duke of Lithuania $\quad 189$

Jonker, Gerdien $\quad$ 10, 12

Justinard, Pierre $\quad 110 \mathrm{n} 15$

Kamal-ud-Din, Khwaja $\quad 48,55,58,60,71$

Kaunas Mohammedan Parish

imam of, state allowance for 200-201

and Kaunas Muslim Society $\quad$ 192-194

mosque of 186,197

state funding for $\quad 188-189,201$

organization of 191

stamp of 192

Kaunas Muslim Society

conflicts with

Raižiai Mohammedan Parish 194, 195-197

Vinkšnupiai Mohammedan

Parish 194, 195-197, 198-199

contacts of, Vilnius-based

Muslims 196-197

and cooperation with government

199, 201

stamp of 192

as state representative $\quad$ 192-193, 195

support for, by Raižiai Mohammedan

Parish 198-199

and unifying Muslim communities

193-194, 198-199, 203

Kavkaz (journal) 220-221

Kemal, Mustafa 208, 222

Khagani 218

Khair-un-Nissa, Dayang Muda of

Sarawak 70, 72, 83

Khan, Inayat $\quad 25^{-26}$

al-Khațīb, Muhiibb al-Dīn

editor of al-Fath $\quad$ 50, 59

views of

on Ahmadiyya movement $\quad 64,78,79$

on European Muslim missions 76

on Ghulam Ahmad 61

on Islamitische Kulturbund 75

Kheiri, Abdul Jabbar

mission approaches of $\quad 23-24,28-29,42$

and Tschelebi 31

views of, on Islamia $\quad 29-30$

al-Khiḍr Ḥusayn, Muhammad 66

Killenger, Muhammed Taufiq 34
Kiram Hishmat, Zeki 65

Kiran, Bin 166

Kongress gegen Koloniale Unterdrückung und Imperialismus (Brussels; 1927) 141

Konieczny, Georg 29, 30, 32, 33

Koningsveld, Pieter Sjoerd van 13, 88-104

Kryczyński, Stanislaw $\quad 178$

Krym. Przesztość, teraźniejszość i dążenia niepodlegtościowe tatarów krymskich

(Seydahmet) 209, 210-211

Lahore

Ahmadiyya movement in

Arslān's correspondence with $\quad 67$

conflicts with, Qadiyani

movement $\quad 48-49$

establishment of 47

philosophy of 25

views on, of al-Khidr 66

Indonesian community in 140

Lane, Edward William $\quad 89-90$

Lausanne 220

Lebensreform 25, 36

Leiden, Muslim communities in $\quad 128,129$

Leiden University Centre for the Study of Islam and Society (LUCIS) 3

liberation movements

in British India 21, 27, 29

in North Africa 29

Lietuvos totoriai (monthly) 178

The Light (periodical) 61, 63, 74

Lithuania, Grand Duchy

Islam in $\quad 181-183$

Tartar communities in

education of mullas/imams in 181-183

mosques of 181

and Russian muftis $\quad 182-183$

Tartars in

first arrival of 210

numerical insignificance of 181

rights and freedoms of 181

Lithuania, State 1918-1940

1923 census $185^{-186}$

conflicts with, Poland 187

founding of 183

government of, and Tartar

communities 199-202

religious freedom in 199 


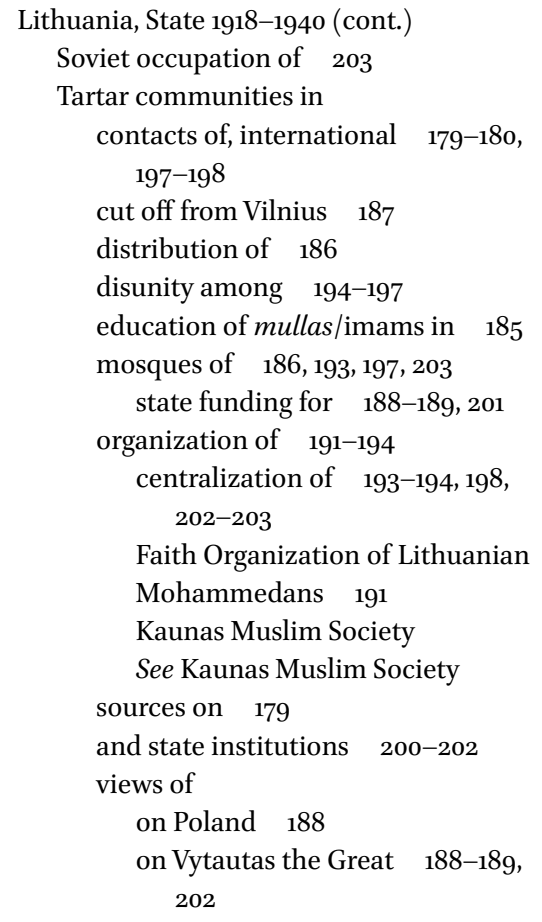

in Vilnius/Wilno (after reunion), redefining of identity by $\quad 189-190$

Tartars in

ethnicity of $\quad 185^{-186}$

numerical insignificance of $\quad 178$

redefining of identity by $180,187-188$, 189, 197-198

Liverpool Muslim Institute 69

Lobauers, Hanns 34

London

Muslim communities in, mosques of 59-61, 69

Muslim missions in See Woking mission

Louis Philippe I, King of the French 90

Ludovico di Varthema 89

Lutheran church, in Germany 19

Lyautey, Hubert 107,110

Madariaga, Maria Rosa $\quad 160$

Maḥmūd, 'Abd al-Ḥalīm (Grand Shayhk of al-Azhar) $66 \mathrm{n} 62,72-73,83$

al-Manār (journal)

contributors to

Headley 53, 57 muslim ghayr mutafarnij $\quad 54-55$

Muslim reformist writers 47,50 views in, on European converts 53

Marcus, Hugo Hamid $\quad 26,27,35-36,37$

Mauvais, Léon 121-122

al-Mayurqīi, 'Abdallāh al Tarjumān $\quad 88$

El Merroun, Mustapha $\quad 160$

Minaret (journal) 69

modernity

anti-modern 19

See also Muslim modernity; religious modernity

Mohammed Khan, Aga 214

Mohammedan Central Council 191

Mohammedan Spiritual Governing

Board 182-183

Mohye, Abdul $\quad 55^{-56,62}$

Mononutu 144

Morgen- und Abendland Verlag 65

Morocco (French protectorate)

architecture of 109-110

as origin of French Islam 107-108

Morocco (Spanish protectorate)

colonial war 156

Muslim communities in, Spanish

Republican bombing of $15^{2}$

Muslims from

fighting in Spanish Civil War See under Spanish Civil War

and Franco-sponsored Hajj 154-155

Spanish racist attitudes against 156 , 158

Moscardó, José 166

Moslemische Revue (journal)

contributors to $26,36,37,38-39$

conversion photographs in $\quad 33-35,37$

on Kaunas mosque 197

launch of 24

photograph of DMG community 41

mosques

in Berlin 20, 24, 39-40, 48, 65, 67

in Ceuta 152

in the Crimea 211

in The Hague $\quad$ 130-131, 139

in Lithuania 181

in Kaunas $186,188-189,197,201$

in Vinkšnupiai 186, 193, 203

in London 48, 59-61, 69

non-Muslim access to $\quad 110 \mathrm{n} 15$ 
in Paris

See Paris Mosque

Muftiate (Poland) 184-185, 191, 197, 199, 202, 203

Muhib, Ali 59-6o

Mullah Nasreddin (journal) 215

Mundo Obrero (newspaper) 154

Munschi, Hilal

education of $206,207,212$

linguistic compentences of 208

political engagement of $208,212-213$

publications of $\quad 213^{-216}$

views of

$$
\begin{aligned}
& \text { on Azerbaijan } \quad 213,214-216 \\
& \text { on orientalism } 213 \\
& \text { on Soviet Union } \quad 213
\end{aligned}
$$

Müsavat Party 212

al-Muslim al-Amil $\quad 76$

Muslim communities

See under specific countries and cities

Muslim converts

See Islamic converts

muslim ghayr mutafarnij $\quad 54-55$

Muslim India (periodical) 54

Muslim Institute (Paris) 106, 108, 113

Muslim missions

in Berlin

Islamia $\quad 29-30$

of Sufi movement $\quad 25^{-26}$

tracing of activities of 22

See also Deutsch-Moslemische

Gesellschaft e.V.; Islam Institute;

Islamische Gemeinde zu Berlin e.V.

in Europe, non-Ahmadiyya $\quad 75^{-76}$

in London

See Woking mission

in Vienna $\quad 73^{-75}$

See also Ahmadiyya movement

Muslim modernity

in Berlin

and Ahmadiyya movement $\quad 10,41$,

$$
\text { 42-43 }
$$

and Ehrenfels $\quad 36,38$

and Fisher, Faruq H. $\quad 38-39$

and Nazism $\quad 38-39$

and Tschelebi $\quad 31-32$

in Europe

and Ahmadiyya movement $\quad 10$

and Nazism 12
See also modernity; religious modernity

The Muslim Review (journal) 71

Muslim/Tartar émigrés/emigrants

in Amsterdam $\quad 128$

in Berlin

duration of stay of $3^{2}$

and IGB 22

views of, on local Islamic converts

33 , 39-41

want of own mosque $\quad 40$

in Delft $\quad 128$

in Europe

anti-communist actvities of 16 , 212, 222

cooperation with Islamic

converts 10

as passive strangers 5

texts of

anti-communist 214

treatment of Islam in 207, 222

See also specific persons

in France

from Algeria $\quad 115,123$

See also Bammate, Haïdar

in The Hague

See The Hague

in Leiden $\quad 128,129$

in the Netherlands

from Indonesia $\quad 125^{-127,138}$

and Ahmadiyya

movement 139-140

composition of $127-128$

contacts with Cairo $\quad$ 143-144

cooperation between 128-129

governmental approach

towards $\quad 135^{-136}$

during Great Depression 134

and international

networks 138-142

See also Perkoempoelan Islam

in Paris

from North Africa

cemetery for 118-119

healthcare of $111,114,115,118$, 119-122

monitoring and aiding of 114-117, 121, 123

mutual aid societies and 117

segregation of 121-123 
Muslim/Tartar émigrés/emigrants (cont.) See also Franco-Muslim Hospital; Paris Mosque

in Poland

See Rasulzade, Mehmed Emin;

Seydahmet, Cafer

in Rotterdam 128

Mușțafā, Ḥasan 96-97, 101

al-Nadwī, Mas'ūd 'Ālim $\quad 64$

Najā, Mușțafā 57

Narutavičius/Narutowicz family 187

National Socialism/Nazism

in Germany 21, 23

and Muslim communities, in

Berlin $\quad 26-27,38$

and Muslim modernity $\quad 12,38-39,43$

Nazir Datoek Pamoentjak $141 \mathrm{n}_{5} 6$

Nazism

See National Socialism/Nazism

Near East, and Caucasus 221

Nehru, Jawaharlal 141

The Netherlands

Ahmadiyya movement in $\quad 139-140$

Chinese communities in $\quad 136$

Muslim communities in

Indonesian $\quad 125^{-127,138}$

and Ahmadiyya

movement $\quad$ 139-140

in Amsterdam $\quad 128$

composition of $\quad 127-128$

contacts with Cairo $\quad 143^{-144}$

cooperation between $\quad 128-129$

in Delft $\quad 128$

governmental approach

towards $\quad 135^{-136}$

during Great Depression 134

in The Hague

See The Hague

and international

networks $\quad 138-142$

in Leiden $\quad$ 128, 129

in Rotterdam 128

See also Perkoempoelan Islam

'sphere sovereignty' in 131

Neumann, Erwin 30

Nicolas I, TSar of Russia $\quad 207$

Nizami Ganjavi $\quad 218$

Nöldeke, Theodore $\quad 92$
North Africa

liberation movements in 29

Muslim émigrés from

in Paris

See under Paris

Nussimbaum, Levi (Bey, Es[s]ad) 30, 31, 213

Oesim, N. 'Baas,' 132

Office of Muslim Beneficence 118

Öl und Blut im Orient (Bey) 213

Orgaz Yoldi, Luis 154

orientalism 213

Ottoman Empire, as ally of Germany $\quad 20$

Pak Bouman (Saiman) 132

Palacíos, Miguel Asín, views of, on Muslim

Moroccan, participation in Civil

War $\quad 156-157$

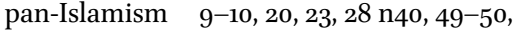
141,143

pan-Slavist ideology $\quad 207-208$

pan-Turanism 217

pan-Turkism 222

Paris

as heart of French empire $\quad$ 112-113

Muslim communities in

of North African immigrants

cemetery for 118-119

healthcare of $111,114,115,118$, 119-122

monitoring and aiding of 114-117, 121,123

mutual aid societies and 117

segregation of 121-123

See also Franco-Muslim Hospital; Paris

Mosque

public health system in $\quad 119-120$

Paris City Council 112

Paris Mosque

building of

agencies involved in $\quad 107$

architects of 111

architecture 106, 108-109 modeled on Bou Inania (Fez) 109

Benghabrit and 109, 113

location 106,108

and ceremonies for landmark

moments 111-112

collaborative vision of $\quad 113$ 
decoration of, mosaics used in 111 as embodiment of French Islam 113, 122 in French civilization $\quad$ 106-107 links with

Franco-Muslim Hospital $\quad 118$

SAINA 118

Moroccan students and $\quad 112$ non-Muslim visitors to 111 and "secular" Islam 111 supporters for, al-'Alawi, Ahmad $113 \mathrm{n} 24$

tourist potential of $\quad 110-111$ views on, in popular press $\quad 110-111$

Père Lachaise cemetery (Paris) 118

Perhimpoenan Indonesia ('Indonesian Association')

conflicts with, van Beetem 131

elite character of 133,134

international contacts of 138,145

Ahmadiyya movement 140

Jawi community Cairo $\quad$ 143-144

at Kongress gegen Koloniale

Unterdrückung und Imperialismus 141

media attention of 129

multi-religious membership of 133

nationalist views of 135

and Perkoempoelan Islam 133

political activities of $\quad 126,134$

Perkoempoelan Islam

activities of $\quad 134-135,145$

contacts of, Baig 139

Dutch character of 137

founding fathers of

Oesim 132

Saiman 132

van Beetem 131-132

founding of 130

functions of $136-137,145$

international contacts of $\quad 137-138$

local and national authorities' view of

$$
135^{-136}
$$

and Perhimpoenan Indonesia 133

political character of 133

representative functions of $132,134^{-135}$

role of $\quad 126-127$

social functions of $\quad 132-133,134$

socio-political views of $\quad 130-131$

van Beetem's resignation $\quad 136$

Permi (Persatoean Muslimin Indonesia) 131
Persia

See Iran/Persia

personal crisis, and conversion 34

Peshawari, Hafiz Abdul Rahman 28 n40

photographs, of converts $\quad 33^{-35}$

Pickard, William Burchell Bashyr 61

Pickthall, Muhammad Marmaduke 63

Pilgrimage to Mecca (Cobbold) $\quad 76$

'pillarization,' 131

Poeze, Harry $\quad$ 126, 140

Polanco, Asín/Anselm 157-158

Poland

conflicts with, Lithuania $\quad 187$

Muftiate in $184-185,191,197,199,202,203$

Promethean strategy of $\quad 209-210$

Tartar communities in

mosques of 186

organizations of $\quad 184^{-185}$

in Vilnius/Wilno (during Polish

occupation)

contacts of, Kaunas Muslim

Society $\quad 196-197$

organization of $184-185,191$

Tartars in

émigré intellectuals from

See Rasulzade, Mehmed Emin;

Seydahmet, Cafer

first arrival of 210

views on, of Lithuanian Tartars 188

POW camps 20

Préfet de la Seine 118

Le Problème du Caucase (Bammate) 220

Promethean networks, in Europe $\quad$ 209-210

propaganda

anti-communist $\quad 212,220,222$

Islamic 48-49, 54

Spanish Nationalist $\quad$ 151, 154-155, 158, 163

Protestantism

in Germany 19

in Russia/Soviet Union, suppression

of 212

Qurān

English translations of

by Ahmadiyya movement 57

by Pickthall 63

German translations of, of von

Ehrenfels 74

Polish translations of $\quad 181-182$ 
racialization, and French Islam $\quad$ 105-106

Račius, Egdūnas 16, 178-204

Rahman, Habibur

and IG B $\quad 27-28,33$

views of

on Abdullah, S.M. $\quad 28$

on Ahmadiyya movement $\quad 39-41$

Raižiai Mohammedan Parish conflicts with, Kaunas Muslim

Society $194,195^{-197}$

mosques in 186

funding of $\quad 188-189$

organization of 191

support for, Kaunas Muslim

Society 198-199

views of, on Vytautas the Great $\quad 188-189$

Rankin, Omar Hubert $\mathbf{6 2}$

Rasjid, Mohammed $\quad$ 144-145

Rasulzade, Mehmed Emin

education of 206, 207, 217

escape to Persia $\quad 217-218$

linguistic compentences of 208

political engagement of $208,217-218$

publications of 218-220

views of, on Azerbaijan 218-220

refugees, Russian, in Weimar

Republic 19-20

Regulares Indígenas 155

religious modernity, use of term 22

Renan, Ernest $\quad$ 208, 221

Die Republik Aserbaidschan. Eine geschichtliche und politische Skizze

(Munschi) 213-216

retailers

Indonesian Muslim, in the

Netherlands 128, 130

Review of Religion (periodical) 63

Richter, Bruno $\quad 30,32$

Riḍā, Muḥammad Rashīd $\quad \mathbf{5}^{2}$

conflicts with, Ghulam Amad $\quad 5^{1-52}$

contacts of, Arslān $\quad 138$

death of $\quad 78-79$

journal of 47

missionary school of 54

views of

on Ahmadiyya movement $\quad 57-58$

on Ahmadiyya's Qurānn

translation 57

on European converts on Headley's conversion $\quad 5^{6}$

on Islam 53-54

on Kamal-ud-Din $\quad 55,5^{8}$

on Sayyid 'Uthmān 99

on Snouck Hurgronje $\quad 93-94$

views on, in Hadramaut $\quad 64-65$

Rifaat, Mansur 65

Roches, Léon 90

Roekoen Peladjar Indonesia 134

Rosenberg, Clifford 119, 123

Rotterdam

Chinese communities in $\quad 136$

Indonesian Muslim communities in $\quad 128$

Ruano, Sanchez $\quad$ 162, 163

Russia/Soviet Union

Islam in

suppression of $\quad 211-212,214-215,217$, 219

views on, of Toğan $\quad 217$

Muslim/Tartars in

émigré intellectuals from

See Toğan, A. Zeki Velidi

occupation of Lithuania 203

pan-Slavist ideology in 207-208

Prometheism and 209-210

Protestantism in, suppression of $\quad 211-212$ refugees from, in Weimar

Republic 19-20

revolution of $1905 \quad 208$

russification strategies in $\quad 207$

views on, of Munschi 213

russification 207

Ryad, Umar $\quad 1-17,47-87,126$

"Rzeczpospolita Azerbajdżańska"

(Rasulzade) 219

Sadr-ud-Din, Khwaja/Mawlana

body of thought of $\quad 24-25$

mission approaches of 28-29, 42

views of, on Ahmad 67

sailors, Indonesian Muslim, in the

Netherlands 128

Saiman (Pak Bouman) 132

Sajid, Mehdi $\quad$ 1-17

Salafì movement

and building of new mosque, controversy

about 69

networks of $49-50$

philosophy of $\quad 47-48$ 
views of

on Ahmadiyya movement 49, 50, $62-63,82$

on European conversions $\quad 5^{1}$

on Sheldrake 69

Salamanca, hospital at $\quad 169$

Salim, Haji Agus 144

Santiago Matamoros 174

Sarida, Ahmad 140

Sastroamidjojo 129

Sa'ūd, Prince 77

al-Sāwī, Shaykh 55

Sayyid 'Ūthmān b.'Aqīlal-'Alawī $\quad$ 98-100

Schiemann, Elsa 30

Schutzman Wider, Joan $\quad$ 126, 133, 134

segregation 121-123

Seiler, Albert $\quad 30,32,33$

Semaoen $141 \mathrm{n}_{5} 6$

Senghor, Lamine 141

Seruan Azhar (journal) 143, 144

Service de la rue Lecomte (North African

Brigade) 114, 115-117

Service des Affaires Indigenes Nord-

Africaines (The North African Native

Affairs Service; SAINA) $\quad$ 115, 118

Service des Beaux Arts (Morocco) 109, 110

Seydahmet, Cafer

education of 206, 207, 209

linguistic compentences of 208

political engagement of 208,209

publications of

on Muslim/Tartar community in

Crimea 210

on Tartar community in Crimea 209

sojourn in, Poland 209

Shah Jahan, Sultan (Begum of

Bhopal) $\quad 59-60$

Shāmil, Shayhk 216

Sheldrake, Khalid $\quad 68-73$

and Ahmadiyya movement $\quad 69-70$

and building of new mosque, controversy

about 59,69

competition with, Ahmadiyya

movement $\quad 71^{-} 73$

conversion of, sincerity/insincerity of $\quad 71$

conversions made by 70

death of 82

meeting with Mahmūd 83

non-sectarian views of 69,70 travels of $70-71$

views of, on Ahmadiyya movement 82

views on

of Cowan $\quad 82-83$

in al-Fath $\quad 68-69$

of al-Hilālī $\quad 71$

of Salafì movement $\quad 69$

and Woking mission 69

Simpson, Conrad (Khalid) 70, 74

Šinkevičius, Jokūbas $\quad$ 184, 189-190, 198-200, 202

al-Siyāsa (daily) $\quad 5^{6}$

Sjahrir 129

Snouck Hurgronje, Christiaan

conversion of

of convenience 101-102

Muslim views on 93

temporariness of $90,91-93$

Islamic marriages of $\quad 90,97,100-101$

Muslim network of

Aboe Bakar $\quad 95^{-96}$

extensiveness of $90-91$

Ḥasan Mușțafā $\quad$ 96-98

Sayyid 'Uthmān $\quad$ 98-100

women in 100-101

al-Zawāwī $\quad 93-95$

non-Muslim network of 90

official functions of 91

stays

in Dutch East Indies $\quad$ 90, 96, 101

in Mecca 90, 93, 100-101

terms of address of $94,96,97-98,99$, 100,102

views on

of Aboe Bakar 95-96

of Riḍā $\quad$ 93-94

of al-Zawāwī 93-94

Société des Habous et des lieux saints de

l'Islam (Society of Habous and Sacred

Places of Islam) 107, 109

Society of Habous and Sacred Places of Islam

(Société des Habous et des lieux saints de

l'Islam) 107, 109, 114

Soe'èb, Muhammad 101

Southfields (London), mosque in $\quad 48-49$

Sovietization 205

Spain

attitudes towards Moroccan

Muslims 156, 158 


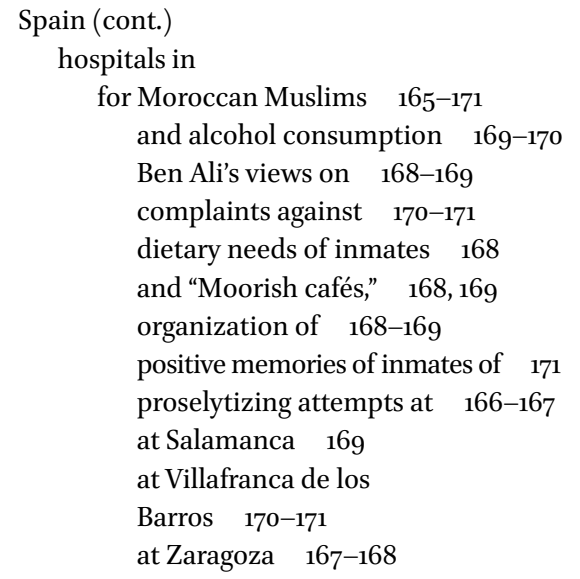

See also Spanish Civil War

Spanish Civil War

Moroccan Muslims fighting in and alcohol consumption $\quad$ 169-170 battle cries used by 162 conversions of $\quad 166-167$ economic motivations of $\quad 160-161$ fasting during Ramadan $\quad$ 172-173 hospitals for

See under hospitals prohibition to visit European cafés $\quad 169$ religious motivation of $\quad 159-162$ religious policies for $\quad 163^{-169}$ concerning burial $\quad 164-165$ concerning stationery $\quad 164$ motives for 174 religiousness/non-religiousness of 151-154, 158-159, 171-173 sexual relations of 172 views of, on Spanish Republicans 162-163 views on, of Catholic clergy $\quad 156-15^{8}$ See also Spanish Nationalists; Spanish Republicans

Spanish Nationalists

propaganda of and the Hajj 154-155 and holy war 151,163 and rehabilitation of the Moor $\quad 158$ views of

on Moroccan Muslims participation in Civil War $\quad$ 156-157 religiousness of $15^{2}, 15^{8-159,171,173}$
Spanish Republicans

bombing of Spanish Morocco 152

views on, of Moroccan Muslims 162-163

'sphere sovereignty', in the Netherlands 131 spiritual journey, and conversion 35 Statute on the Taurida Muslim Clergy 182 Stewart-Rankin, Omar 79 students

$$
\text { Indonesian Muslim }
$$
in the Netherlands $\quad 127-128$ contacts with Cairo $\quad 143^{-144}$ and international networks 140-145 political views of 129 social formations among $\quad 129$ Jawi Muslim

in Cairo arrival of 143 contacts with the Netherlands 143-144

Stutje, Klaas $14,125^{-15^{0}}$

Subardjo, Achmad 141 n56, 142, 143, 144

Sufi movement (Sufi Bewegung e.V.) $\quad 25^{-26}$

Sulaiman 142

Syria, circulation of Ahmadiyya's Qurān translation in 57

Szynkiewicz, Jakub 184, 189-190, 198-200, 202

Ṭāib, Muḥammad 101

Tajib, Djanan 144

Talavera, Muslim cemetery in $\quad 165$

Tarīqa 'Alawiyya movement $\quad 113 \mathrm{n} 24$

Tartars

conversion to Christianity of $184 \mathrm{n} 13$

émigré intellectuals

education of 206,207

linguistic compentences of 208

redefining of identity by 207

and russification $\quad 207$

etymology of term 211

use of term 180

See also under Lithuania; Muslim/Tartar émigrés; under Poland

Tatarzy litewscy. Próba monografii historycznoetnograficznej (Lithuanian Tatars. An attempt at historic-ethnographic monograph; Kryczyński) $\quad 178$

Tetuan, bombing of $\quad 15^{2}$ 
The Star of India (journal) 39-40

Toğan, A. Zeki Velidi

education of $206,207,216$

linguistic compentences of 208

political engagement of 208

speech of 216-217

Tranchant de Lunel, Maurice 110

Transnational Islam in Interwar Europe

(Nordbruch \& Ryad) 1

Tschelebi, Mohammad Nafti

body of thought of $25,31-32$

and IGB $\quad 32$

and Islam Archive 31

and Islam Institute $\quad 31$

and Kheiri 31

Tuma, Ali Al $\quad$ 15-16, 151-177

Turkestan, Sovietization of 205

El Uariachi, Mohammad $\quad 167$

United Kingdom (UK)

Ahmadiyya movement in $\quad 49$

See also London; Woking mission

United States (USA)

Ahmadiyya missionaries in 61

Christian missions in 61

van Beetem, Mohammad Ali

aid to members of Perkoempoelan

Indonesia 134-135, 137

conflicts with, Perhimpoenan

Indonesia 131

conversion of 130, 144

at European Muslim Congress 1935

138-139, 145

political views of $130-131$

promotion of Muslim interests 131

resignation of 136

role of 126

travels of, to Egypt $\quad 144-145,147$

van Koningsveld, Pieter Sjoerd $\quad$ 13, 88-104

Varela, José Enrique $\quad 165$

Vienna $\quad 73^{-75}$

Villafranca de los Barros, hospital at $\quad 170$

Vilnius/Wilno

mosques in 186

Polish occupation of 184,185 reunion with Lithuania $\quad 189$

as Tartar center $\quad 181,184,187$

Vinkšnupiai Mohammedan Parish

cemetery of 193, 203

conflicts with, Kaunas Muslim

Society 194, 195-197, 198-199

mosque of $186,193,203$

organization of 191-192

Visage de l'Islam (Bammate) 221

Voigt, Werner 30

Voldemaras, Augustinas 200-201

Vytautas the Great, Grand Duke of

Lithuania $\quad$ 188-189, 202

Weimar Republic

See Germany/Weimar Republic

Weiss, Leopold (Asad, Muhammed) $\quad 30-31$, 88-89

A Western Awakening to Islam (Headley) 57

Western Islamic Association 59, 69

Wilder, Gary $\quad$ 112-113

Wilhelmina, Queen of the Netherlands 99

Witkam, Jan Just 92

Władyslaw II Jagiełło, King of Poland 189

Woking mission (London)

Ahmadi affiliation of $\quad 59,76-78$

central role of 48

conversions by 51,76

demand for disassociation Ahmadiyya

movement 79

differences with Qadiyani branch $\quad 60-61$

and Headley, 5 th Baron 82

Id-ul-Fitr day at $\quad 5^{8}$

Sheldrake and 69

views on, in al-Fath $\quad 76-78$

See also Abdul-Majid, Mawlana; Mohye,

Abdul

women, equality for 215

Wright, Gwendolyn 110

Wschód-Orient (journal) 219

Young Turks 208

l-Ẓawahīrī, Muḥammad al-Aḥmadī 144

al-Zawāwī, al-Sayyid 'Abdallāh b. Muḥammad

b. Șālih $\quad 93-95$ 